\title{
AN EXAMINATION OF TEACHING AS PRACTICAL POLITICAL ACTIVITY \\ by
}

Anne M. Phelan

\begin{abstract}
Dissertation submitted to the faculty of the Virginia Polytechnic Institute and State University in partial fulfillment of the requirements for the degree of
\end{abstract}

DOCTOR OF EDUCATION

in

Curriculum and Instruction

\section{APPROVED:}

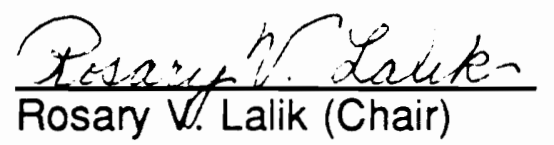

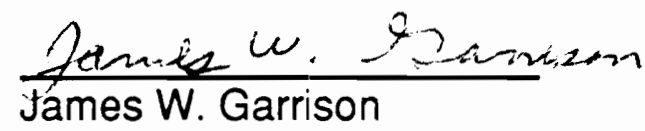

Tan Tespor

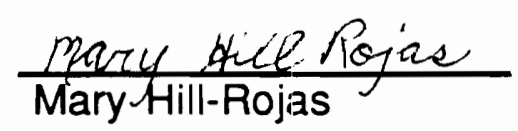

$\frac{\text { Aure Solis }}{\text { Ruth Salvaggio }}$

July, 1990

Blacksburg, Virginia 


$\angle D$


5655
$V 856$
1990
$P 546$
$C .2$




\title{
AN EXAMINATION OF TEACHING AS PRACTICAL POLITICAL ACTIVITY
}

\author{
by \\ Anne M. Phelan \\ Committee Chairperson: Rosary V. Lalik \\ Curriculum and Instruction
}

\begin{abstract}
This dissertation examined the notion of teacher as an agent of social change. The participants were feminist, university teachers. The study is important because it explored schools as political sites where teaching and learning are understood in terms of democratic citizenship and social justice. The theoretical base for the research was neo-marxist theory drawing specifically on the concept of teacher as "transformative intellectual".

The case study strategy, following an ethnographic model, was the qualitative research method employed. Symbolic interactionism was the theoretical orientation of the methodology. It was selected because of its consistency with the perspective that meaning is socially constructed which was an assumption of the study. Data analysis took the form of the constant comparative method. Two notions of validity that guided the study were the mutual development of
\end{abstract}


self-consciousness by inquirer and respondents, and the creation of a dialogical ethnographic text which avoids violation of the participants realities.

The findings of the study suggest that the notion of transformative intellectual may rely too heavily on abstract, and highly rationalistic, constructions of "experience", "empowerment" and "dialogue" as transformative strategies. Moreover, the study underscores a need to attend to the transformative intellectual as complicit in the production, and legitimation, of certain kinds of knowledges, in the context of pedagogy as an "interactive productivity". Additionally, "transformative" may not refer to a state, or characteristic, of an individual teacher but rather to a relationship between individuals in a group. Finally, the study points to the immense difficulties posed by the university institution to the work of the would-be transformative intellectual. Further research may be needed to explore individual and group efforts to overcome those difficulties faced by the teacher as an agent of social change. 
DEDICATION

To My Mother,

Anastasia Barron Phelan

With

Love and Gratitude 


\section{Pessisism of the Intellect, Optimism of the Will. \\ - Antonio Gramsci}

Those to Dare to Act Can Accomplish Much

- Jane Austen 


\section{ACKNOWLEDGEMENTS}

This dissertation is about social justice. It explores the lives of three women whose work represents a struggle for social equity. Many people deserve credit for their part in bringing the notion of social justice, as an important educational ideal, to my attention, and in facilitating the development of my understanding of it.

I wish to thank Muireann, Chloe, and Gale whose work toward, and commitment to, social justice will remain inspirational to me.

I acknowledge the members of my committee, Drs. Rosary Lalik, Jan Nespor, James Garrison, Ruth Salvaggio and Mary Hill-Rojas. They were supportive of my work and always eager to enter into discussion with me. In this regard, I mention especially Dr. James Garrison who has led me toward a deeper understanding and appreciation of the philosophy of education and educational research. I want to express my sincere thanks to Dr. Jan Nespor, with whom sociological and anthropological disagreements were never disagreeable, and always informative. Drs. Nespor and Garrison have been, and will remain, I hope, my mentors and my friends.

I have been extremely fortunate and privileged to have Dr. Rosary lalik as my advisor, during the last four years. 
Over that period, I witnessed her extraordinary skill as an educator, a skill paralleled only by her commitment and concern for the well-being of her students. She has devoted countless hours to my development as a scholar; my hope is that my scholarship will continue to reflect the careful thoughtfulness that she has always modelled.

My thanks to three wonderful friends and room-mates, Dr. Susan Eerro, Kathy Moynan and Fay Cotton. They have taught me much about myself! Each, in her own way, has demonstrated that care, concern and connection between individuals form a firm basis on which to build community and social justice. Four years ago I left my family in Ireland to study in the United States of America; it seemed, however, that they were never far away! Their constant attention, by means of letters, phone-calls, and thoughts, has brought me to this day. I express my sincere appreciation to my mother, Anastasia Barron Phelan, my brother, Patrick Phelan, my aunt, Catherine Barron Halpin and my cousin, Anne-Marie Kealy, for their vigilance on my behalf.

Finally, I wish to acknowledge Paul Winkelman whose commitment, humor and confidence helped me to persist and strive to reach my goal. 
TABLE OF CONTENTS

Page

ABSTRACT . . . . . . . . . . . . . . . . . . . . .

DEDICATION . . . . . . . . . . . . . . . . . . . . iv

ACKNOWLEDGEMENTS . . . . . . . . . . . . . . . . . $\mathrm{V}$

TABLE OE CONTENTS . . . . . . . . . . . . . . . . vii

PROLOGUE • . . . . . . . . . . . . . . . . . . . . 1

Changing Perspectives . . . . . . . . . . . 1

The Research Problem . . . . . . . . . . . 5

ENDNOTES . . . . . . . . . . . . . . . . . . 8

CHAPTER 1 - BACKGROUND TO RESEARCH PROBLEM . . . . 11

Socialization . . . . . . . . . . . . . . . 11

Professionalization . . . . . . . . . . . 14

Democratization . . . . . . . . . . . 17

Key Concepts Transformative Intellectual . . . 22

Transformative Intellectual: Concept 4.46

Institutional Value/Educational Values. . . 26

Student Voice/Teacher Voice . . . . . . 28

Rational Subjects/Meaning-Makers . . . . . . 30

Women, the University and Reform . . . . . . . 31

Eeminism . . . . . . . . . . . . . . 34

Women's Studies... . . . . . . . . . . . . 37

Consciousness and Social Change . . . . . . . . 42

Objectives of the Inquiry . . . . . . . . . . . 44

ENDNOTES . . . . . • • • . . . . . . . . . . . 45

CHAPTER 2 - CASE STUDIES . . . . . . . . . . . 48

CASE 1 - MUIREANN . . . . . . . . . . . . . . . . 48

Introduction . . . . . . . . . . . . . . . . . . . . . . 48

Narrative as Personal - Vignette . . . . . . . 49

Narrative as Personal - Exposition . . . . . 60

A Sense of the Personal . . . . . . . . 60

A Private-Public Tension... . . . . . 63

Personal Narrative and Student-Process. . . 65

Literature as a Vehicle of the Personal . . 68

Narrative as Social - Vignette . . . . . . 72

Narrative as Social - Exposition . . . . . . 77

An Ethic of Relation . . . . . . . . . . 78 
Student Perceptions of Relationships... . 81

Narratives of Experience as Performances of Meaning - Vignette . . . . . . . . . 90

Narratives of Experience as Performances of Meaning - Exposition . . . . . . . . . 96

A "Difference-Response" . . . . . . . . . . 97

Teacher vs. Students: The Irony

of Difference . . . . . . . . . . 102

Narrative in the Context of Political
Discourse - Vignette . . . . . 105

Narrative in the Context of Political
Discourse - Exposition . . . . . 107

Teaching is Political? . . . . . . . . . 107

Rape and Agression (Vignette) . . . . . . . 110

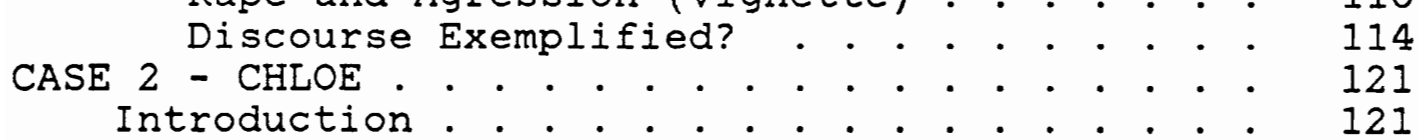

Chloe's Classroom: A Vignette . . . . . . 124

Finding "Voices" . . . . . . . . . . . . . . 136

Approaching Dialogue: A Conversational

Moment Within . . . . . . . . . . . . . . 144

The Knowledge-Power Nexus (Dialogue) . . . 144

A Knowledgeable Woman (Exposition) . . . 150

An Institutional Authority (Dialogue) . . . 157

An Authoritarian Privilege

(Exposition) . . . . . . . . . . . . 162

Passionate politics (Dialogue) . . . . . 166

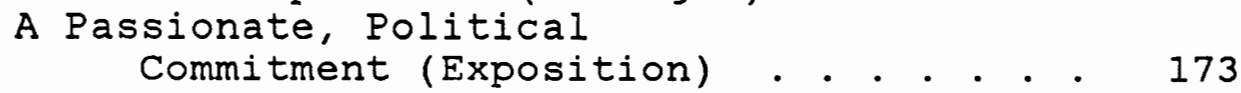

CASE 3 - GALE . . . . . . . . . . . . . . . . . 183

Introduction . . . . . . . . . . . . . . . . . 183

Personal History: A New Dimension. . . . . 185

Women and Representation
4000 - Vignette . . . . . . . . . . 194

A Public Transition . . . . . . . . . . . . . . 196

Film Viewing - Vignette . . . . . . . . . . 199

First Moves: Film viewing - Exposition . . . 203

Interpreting Theory - Vignette . . . . . . 206

Interpreting Theory and Struggles
for Teacher Autonomy - Exposition . . . . 215

Knowledge: The Teacher's

Route to Autonomy . . . . . . . . . . . 215

Faculty Presence: A Threat to
Teacher Autonomy . . . . . . . . 217

Teacher Autonomy and Student Silence . . . 219

Negotiating the Person-Teacher Boundary:
A Struggle for Autonomy . . . . . 230

Vulnerability and the Institution... . . . 234 
CHAPTER 3 - EINDINGS . . . . . . . . . . . . . 239

Introduction . . . . . . . . . . . . . . . . . 239

Key Constructs: Experience, Empowerment

and Dialogue... . . . . . . . . . . . . 240

Experience . . . . . . . . . . . . . . . . 241

Empowerment . . . . . . . . . . . . . . . . 245

Dialogue . . . . . . . . . . . . . . . . 248

Knowledge Construction and
Transformative Pedagogy . . . . . . . . . 252

Knowledge as Process: Experience as a 254

Knowledge as Product: Dilemmas of knowing . . . . . . . . . . . . 257

Transformation as a Social Act . . . . . . . 261

Transformative Intellectual and the Academy . . 268

The Problem of Academic Scholarship . . . 270

The Problem of Political Pedagogy . . . . . 271

Conclusion . . . . . . . . . . . . . . 273

CHAPTER 4 - REFLECTION ON THE RESEARCH PROCESS • . 275

Gaining Access? . . . . . . . . . . . . . . 275

An Important Premise . . . . . . . . . . . 282

A Case of... . . . . . . . . . . . . . . . 282

In The Field. . . . . . . . . . . . . . . . 285

In The Field, Together! . . . . . . . . 288

To Talk, To Write, To Code: To Analyze . . . 295

To Bias or Not To Bias...?. . . . . . . . 302

A Question of History . . . . . . . . . . . 311

A Einal Word...For Now . . . . . . . . 313

REFERENCES . . . . . . . . . . . . . . . 315

APPENDICES . . . . . . . . . . . . . . . 324

A - Teacher's Contract, 1920 . . . . . . . . 324

B - Course Syllabi . . . . . . . . . . . 326

C - Faculty and Student Consent Forms . . . . 336

D - Social Processes and Meaning:
Symbolic Interactionism . . . . . . . 341

E - Data Analysis: Memos and Visual
Displays . . . . . . . . . 347

VITA ................... . 355 


\section{PROLOGUE}

\section{Changing Perspectives}

I can tell you what this dissertation is about at its core by citing a distinction of John Dewey's. The distinction is between "education as a function of society" and "society as a function of education." I agree with Lenntrichia (1983) when he says that basically "this distinction is a way of dividing the world between those who like it and those who do not."

One year ago I began as a graduate student to take Women Studies courses [Introduction to Women's Studies, Women and Creativity, and Feminist Theory]. Throughout the year I met many women--academic feminists ${ }^{1}--$ who didn't like their worlds. These female intellectuals expressed their dissatisfaction with society in classrooms, at meetings, and by the films that they brought to campus. The reason for their unease was fundamental: society (western) was stricken with a morality of power ${ }^{2}$, a morality that survived by its construction and reproduction of oppressive relations of domination. In the U.S.A., for example, the wealthiest nation that has ever existed, 15 percent of the population-that is, one out of every seven--live below the government's official poverty line (calculated at $\$ 5,278$ for an individual in 1984); nearly one quarter of all the children in the 
United States under the age of six live in poverty (Rothenberg, 1988). The tapestry of repression, as it were, was woven in strands of racism, sexism, and classism, among others.

The Women's Studies courses had a variety of effects on me. At times I felt my naivete exposed, confronted and challenged; on other occasions I was angry at the cynicism and seeming "paranoia" of the Women's Studies professors; more often I was fascinated by the activity of these academic women who were clearly committed to transforming society from their academic classrooms.

Though I have completed the Women's Studies courses certain questions still trouble me. The questions force me to look inwardly and reflect on my practice as an educator. As a teacher in Irish public schools I felt very much at home, very comfortable. I sought to prepare young minds to "fit in", to "make it" in white, Catholic, Irish society. I taught in an all female school. I graded papers and prepared students for examinations that would provide them with the "cultural capital" [diplomas] that would eventually find them jobs in the market place. I taught Religious Education-Catholicism. I had been a good teacher. I had cared. No one could tell me that I had not done my duty to "God and Country".

BUT... the Women's Studies professors made much of my hard work seem so "wrong" somehow. It was not as if they had ever 
commented directly.... It was just those probing questions that their very activities presented--whose interests was I really serving in the classroom? What repressive myths was I perpetuating? What systems of morality was I reproducing? Suddenly I was looking inside my classroom and seeing there within the four classroom walls a relationship between society and school being played out, unknown to the diligent but unreflective ${ }^{3}$ teacher--myself. Burke (1961) calls my earlier approach in the classroom "normal"--education involved in a process of normalization.

...of making normal, of ensuring that its pedagogical subjects will be trained so that they will be happy, useful, productive, and safe subjects, in the social and political sense of the term: they will be cunningly "subjected".

(Burke, 1961)

But did I really believe this? I mean schools have always been agents of socialization--nothing new about that. To react in this manner, though, seemed to underscore my own normalization achieved by my teachers, professors and myself. To be a 'happy', 'useful', and 'productive' individual had such positive connotations previously but now I felt confused. Two of Burke's words really disturbed me: "safe" and "subject". No longer might I see myself as an autonomous "self". I now appeared as someone who had internalized patriarchal morality ${ }^{4}$ and was reproducing it in the classroom. Was I diligent but unreflective... and thus 
'safe'? Was I becoming as "paranoid" as those academic feminists??!!

The images that invaded my practical consciousness contradicted all the explanations that my theoretical consciousness could muster. ${ }^{5}$ As I reflected on my personal and professional experience as a teacher I could not reconcile the rhetoric of "child-centered curriculum theory" and my actual school practices. I remembered one of my neighbors label me "the lady on our street", that is, the only individual that had seen the interior of an institute of higher education. Then the face of Mary White came to mind... the bright working class student in my 6 th grade classroom who was placed in a low track on entry to secondary school because, as the principal explained, "None of her family ever did anything worthwhile". I imaged rows of children singing "Nearer my God to Thee", and the unquestioned and unquestioning religious education in which I had participated. The last image always brought forth gymslipped little girls with thoughts only of teaching, nursing and the "feminine" professions whilst their male counterparts dreamt of building bridges and flying planes--in gendersegregized Irish schools.

What to do with such images? Where to find peace from them? Life was becoming harder to live or so it seemed. I resorted to a belief that education couldn't change society. A total rethinking and reforming of the capitalist agenda-- 
the accumulation of capital and the logic of the market place according to Michael Apple (1986)--was necessary. Shaull's from the comfortable complacency to which I, the educator, was returning. Shaull (1970) insisted that I could not take a neutral stand; I had to decide whether I liked society or I didn't....

There is no such thing as a neutral education process. Education either functions as an instrument which is used to facilitate the integration of the younger generation into the logic of the present system and bring about conformity to it, or it becomes "the practice of freedom", the means by which men and women deal critically and creatively with reality and discover how to participate in the transformation of their world.

(Shaul1, 1970)

Shaull's words seem to confront as well as challenge me as a teacher.

\section{The Research Problem}

Educators such as you and I seem to have two options according to academic feminists and critical theorists ${ }^{6}$ such as Shaull: to be instruments of conformity [to the status quo] or agents of social change. As an agent of change the role of the teacher becomes politicized. Neo-marxists in education have for some time theorized on the political role of the teacher; while academic feminists seem to be living out that role; in so doing they are creating their own 
version of critical "theory in the flesh" (Hooks, 1987). This project explored the notion of the teacher as an agent of social change--a "transformative intellectual". 7 The teachers that became the focus were academic feminists, teachers of Women's Studies courses.

Both academic feminists and critical theorists adhere to the Deweyian notion of the relationship between schooling and social change, and both groups base their transformative agendas on this assumption. Moreover, both agendas are moved by a democratic vision....8

A world free not only from sexism but also from racism, class bias, ageism, heterosexual bias--from all the ideologies and institutions that consciously or unconsciously oppressed and exploited some for the advantage of others.

(National Women Studies Association)

Rather than ascribe to the present depoliticization of schooling in favor of an economic, market-place orientation, both groups [academic feminists and critical theorists] view schools as political sites where teaching and learning are understood in terms of democratic citizenship and social justice.

It is interesting, and perhaps "pointed", that the feminist critique and the critique of critical theorists [neo-marxist] on education have remained peripheral in effect, colleges of education remaining largely untouched by either critiques (Lather, 1983). In this dissertation 
project I have attempted to integrate the literature on feminist and critical theories as a basis from which to explore the possibilities of schooling as an instrument for social change, and teaching as "practical political activity" (Gramsci, 1971)--transformative praxis in the classroom.

Women's Studies was seen, therefore, as an appropriate empirical grounding for the further development of a critical theory of education (Lather, 1983). 


\section{ENDNOTES}

1. Women's studies professors participating in this study are satisfied with my use of the term "academic feminist". However, as this document progresses we will see how problematic the term "feminist" is.

2. I am using the term "morality" in the sense used by Marilyn French (1985) in her book "Beyond Power". [New York: Summit Books.] French defines "morality" as follows: "...the set of values by which we judge, which guide our behavior, and even our emotions. Morals are real values... O Our moral system is a system of priorities, or, rather a texture, an interlocking set of shifting, ambivalent, and conditional goods and ills." (Introduction, p.2)

3. Borrowing from stephen Kemmis in his essay "Critical Reflection" [In Staff Development or School Improvement 1987. (Eds.), M. Wideen \& I. Andrews. New York: The Falmer Press], "unreflective" means failing to explore "explicitly, consciously and self-consciously" the social and historical nature of one's educational practice. 
4. Marilyn French [See endnote 3.] describes patriarchal morality as a morality that "reveres power above everything else and is willing to sacrifice everything else to power." (Introduction, p.5)

5. Gramsci (1971) argues that people have a practical consciousness that co-exists with a contradictory theoretical, ideological consciousness. Practical consciousness is a mixture of class prejudices and myths, fragments of the dominant social ideologies, regional/cultural taboos and social and religious directives--all together these make up "common sense" in Gramsci's terms. Practical consciousness also contains within it a kernel of "good sense" which develops as we learn to play or "beat" the system. Theoretical consciousness is constituted by dominant social ideologies--our received explanations of the way things are in society. Theoretical consciousness is transmitted by social institutions such as the family and the school.

6. Patricia Lather (1983) writes that generally Neo- Marxism is equated with Cultural Marxism or Western Marxism. This author suggests that Neo-Marxism can be further divided into the many forms of "Marxist revitalization": neo-Hegelian, Althusserian "scientific" neo-Marxism, critical theory, Marxism-feminism/Socialist feminism. 
Throughout this document I use "Neo-marxist" to describe proponents of critical theory. Hence, "neo-marxist" and "critical theorist" are used interchangeably.

7. A transformative intellectual is a teacher who not only reflects on and analyzes various interests and contradictions within education and society but also attempts to effect a political consciousness in students. The goal is to educate students "to take risks and to struggle within ongoing relations of power in order to alter the oppressive conditions in which life is lived" (Giroux \& McLaren, 1986).

8. The vision here is one of a democracy: a social condition of classlessness and equality, where government is by the people or by representatives whom the people are and feel empowered to elect. 


\section{CHAPTER 1}

\section{BACKGROUND TO RESEARCH PROBLEM}

As neo-marxists theorize about teachers as agents of social change and academic feminists attempt to enact the transformative scenario in the university classroom, we may well question the possibilities for widespread/public school application of the notion of "transformative intellectual". Traditional and current perspectives on the purpose of public schooling and the role of teachers seem to have a twofold focus: preparation for society--socialization; preparation for the workforce--professionalization. The question remains as to whether either focus is compatible with democratic schooling--democratization.

\section{Socialization}

Sociologists (Hurn 1985; Ballantine, 1987) suggest that schooling is controversial in any society; schools are the sites of education. Education is a deliberate process of cultural transmission that involves

...the selection of certain ideals, values, and skills that are deemed as of sufficiently great importance not to be left to chance and therefore must be deliberately and intentionally conveyed to the young.

$$
\text { (Hurn, 1985: 4) }
$$


It is the deliberate nature of the process of education that differentiates it from the broader notion of socialization (Ginsburg, 1988; Hurn, 1985).

The transmission of culture involves a
struggle between competing values and
competing conceptions of an ideal society,
and arguments about education are always
shaped by that larger debate.

(Hurn, 1985: 6)

Current curriculum issues such as sex education, creationism and evolution reflect the conflict between values and ideals of interested groups. For example, the teaching of evolution represents to some (conservative fundamentalist Christians) a retreat into relativism and the rise of schools as dens of godless secularism. If schools are the instruments through which society can provide the young with the "opportunity to share in and subscribe to the particular values and ideals that make a society distinctive", then it is understandable that any current anxiety about the condition of society should be targeted at the schools (Hurn, 1985). The emergence of public schooling in the era of "the New Republic" is an interesting historical example of schools as instruments of cultural transmission.

Historically, the Founding Fathers of the United States of America recognized the important role that education could play in reconciling freedom and order in the new republic and in fostering the intelligence required of republican citizens (Kaestle, 1983). 
A sound education would prepare men to vote intelligently and prepare women to train their sons properly. Moral training based on the Protestant Bible would produce virtuous, well-behaved citizens.

$$
\text { (Kaestle, 1983:5) }
$$

The new republic was the ideal of a new social order, different from "corrupt" Europe. The theme of national integration was to be reflected by a thoroughly "American" curriculum reflecting the "principles, opinions, and manners of a republican". As Webster expressed it

Begin with the infant in his cradle... Let the first word he lisps be Washington...

(Kaestle, 1983: 7)

Webster also called on the common school to instill in American children "an inviolable attachment to their own country" (Kaestle, 1983:7). Benjamin Rush urged for the creation of a national university "where the youth of all the states may be melted away (as it were) together into one mass of citizens"(8). In an essay written in 1786, Rush leaves us in no doubt as to the role of education as he saw it:
In the education of youth, let the authority of our masters be as absolute as possible... By this mode of education we prepare our youth for the subordination of laws and thereby qualify them for becoming good citizens of the republic.

$$
\text { (Kaestle, 1983: 8) }
$$

Education was thus viewed as the instrument by which to achieve political conformity and disciplined behavior. 
State-supported common schooling was proposed as the practical answer.

Teachers were seen as the primary socializers of children; even today teachers are still seen as playing an important role in teaching the child how to be a member of society (Ballantine, 1983). Across time the role of socializer has dictated certain expectations from society of the teacher. The teacher's contract of 1923 (Appendix A) bears witness to such expectations. So does the the heated debate of the late seventies surrounding the issue of homosexual teachers in the classroom (Newsweek, 1978). Teachers as socializers are expected to set good moral examples for students--the question of whose morality is always a controversial one.

\section{Professionalization}

The current dominant influence on public schooling is technical rationality. Aronowitz and Giroux (1985) write, "that with the advent of the twentieth century, the administration and organization of the public schools were increasingly brought under the influence of the instrumental ideologies of corporate business interests." The purpose of public schools has become closely linked to supporting the ideological and social practices of a business society.

Modern schools tend to emphasize academic knowledge-cognitive skills--and increasingly education is being defined 
in terms of training for some particular occupation (Apple, 1985; Hurn, 1985; Giroux \& McLaren, 1986). In 1900 most U.S. children left school by the age of ten or eleven years; today over $40 \%$ of seventeen and eighteen year olds continue on to some form of higher education (Jencks, 1972; Woods \& Martin, 1987). The rationale for this trend is presented as follows: in a complex society we need highly educated and well-trained individuals. Contrary to this belief many critics suggest that though those with impressive educational credentials are more likely to get jobs than those who do not have such credentials, there is no indication that those particular jobs require the level of credentials requested (Collins, 1979).

Schools have become increasingly associated with status allocation in modern societies (Hurn, 1985). The amount of schooling one has completed plus the particular credentials one has acquired have a "powerful and lasting effect on [one's] subsequent status" (Weber, 1948). Hurn (1985) goes on to say that status, by its very nature, is scarce and desirable. Hence, a cycle of competition is set up. Students compete for grades in order to gain entry into particular colleges; while in colleges they cornpete for certificates and degrees which they then use to acquire occupational status. Hurn (1985) suggests that competition arises also between groups for educational success: those who have high status try to preserve it by sending their children 
to prestigious colleges and universities; while those who are disadvantaged attempt to improve their position (economically and socially) by better educational opportunities. Conflict can result between groups as for example in the U.S.A. where issues such as bilingual education are the subject of educational debate. The roots of the bilingual debate might be defined in terms of a debate over whether to legitimate the knowledge of powerless groups thus increasing their accessibility to power. Hurn (1985) believes that the roots of all educational debates lie in such struggles for status and power between groups: minorities and women versus white males.

There seem to be competing expectations of teachers in terms of their roles. Teachers are expected to help children master "the 3 R's" as well as a host of other subject areas (Martin \& Woods, 1988). As the purveyor of knowledge and skills increasing emphasis is placed on the academic intellectual prowess of teachers (Holmes Report, 1986). As schools take on the role of "training for future occupations" teachers become the grand equalizers, facilitating status achievement and economic benefits for those previously disadvantaged (Hurn, 1985). On higher levels in the educational hierarchy [universities] teachers find themselves responsible for technical progress and subsequently economic growth. Current expectations of teachers either side step or abandon altogether the 
principles underlying education for a democratic citizenry developed by John Dewey and others in the early part of this century (Giroux \& McLaren, 1986). Education as democratization involves the education of individuals who by reflection and action stimulate processes of political and cultural change, refining and elaborating the workings of political democracy. Neo-marxist scholars in education are currently re-presenting the case for democratic schooling.

\section{Democratization}

Critical theorists present the case for democratic schooling by arguing that current educational reforms ${ }^{1}$ [A Nation at Risk; Action for Excellence, A Nation Prepared: Teachers for the 21 st century\} are driven by a conservative ${ }^{2}$ ideal of schooling. Giroux and McLaren (1986) write that the conservative ideal of schooling redefines the purpose of education so as "to eliminate its citizenship function in favor of a narrowly defined labor market perspective". Schools are not defined as agencies of equity and justice; there is little concern with how schools could better serve the diverse interests of students by enabling them to understand and gain some control over the sociopolitical forces that influence them; the utility of schools is measured against their contribution to economic growth and cultural uniformity (Giroux \& McLaren, 1986). 
Critical theorists also argue that the school, as a reflex of the labor market, plays an important part in the reproduction of oppressive relations.

As reproductive sites that smoothly provide the knowledge, skills, and social relations necessary for the functioning of the capitalist economy and dominant society, public education no longer provides tools for critical thinking and transformative action.

$$
\text { (Giroux, 1985:xi) }
$$

Teachers help construct and reproduce unequal and oppressive relations of class, race, and gender that are particular to capitalist society (Apple, 1985). On this account capitalism is not only distinct from but seems to conflict with the notion of democracy. Current school reforms indicate a concerted effort to maintain teachers in their reproductive capacity. Ginsburg (1988) and Kemmis (1987) point to the present role and status of teachers implicit in the latest reforms. Teachers are prevented from "collectively and creatively shaping the conditions under which they work" (Giroux \& McLaren, 1986). Stedman and Smith (1983) list some of the new reforms as attempts to "teacher-proof" schooling: competency-based testing for teachers, mastery learning techniques, systematized evaluation schemes, standardized curricula and the mandated "basics". Increasingly, teachers are being rendered non-intellectual (Giroux \& McLaren, 1986), de-skilled (Apple, 1985), and proletarianized (Ginsburg, 1988) 
As teaching is defined in terms of reductionistic concepts such as competencies, standardization, and performance skills so too is learning (Giroux \& McLaren, 1986). Students learn to adapt to rather than question a society that "glorifies hard work, industrial discipline, domesticated desire and cheerful obedience" (Giroux \& McLaren 1986). We are reminded here of Burke's "safe, useful and productive subjects" of the prologue.

The neo-marxist critique suggests that the "new conservative" discourse in education strips the definition of schooling of any democratic vision "where citizenship and the politics of possiblity are given serious consideration." (Giroux \& McLaren, 1986). Thus, the "crisis" in schooling is restated, as a crisis in democracy in the United States of America. Giroux and McLaren (1986) underscore the "the need to reclaim a democratic tradition presently in retreat." To do so, they have developed a language of democratic schooling which includes three constructs: empowerment, dialogue and experience.

The language of democratic possibility begins with the empowerment of individual students. Empowerment begins with "appreciating and loving oneself" (Aronwitz, 1986), and moves on to the political apprehension of self and one's reality. Empowerment refers to the process whereby "students acquire the means to critically appropriate knowledge existing outside of their immediate experience in order to broaden 
their understanding of themselves, the world, and the possibilities for transforming the taken-for-granted assumptions about the way [they] live" (Giroux \& McLaren, 1986). Students begin to see themselves as "subjects" whose positions and priviledges are mediated in terms of class, race, and gender. The indignation that results on the part of the student requires positive action to eliminate injustice and social inequalities. The challenge for the individual becomes not one of serving the dominant culture but defining it and transforming it on more democratic terms. When schooling is defined as a process of empowerment schools become "public spaces", (Arendt, 1958), where students learn to engage in critical inquiry and dialogue. Students learn to be concerned with justice, freedom and equality. Moreover, students are confronted with local issues around which they can become personally and actively involved in the creation of a critical democracy. Teaching, learning, schooling are thus politicized. No longer satisfied with adapting to the existing social order students and teachers are involved in "challenging the social order so as to develop and advance its democratic imperatives" (Giroux \& McLaren, 1986).

Dialogue is described by critical theorists as a process of deliberation and discussion between participants who exhibit trust, sharing and commitment to improving the quality of human life. It is a democratic form of 
communication in which all voices and differences become unified, both in their effort to identify and recall moments of human suffering, and in their attempts to overcome conditions that perpetuate such suffering (Ellesworth, 1989). Dialogue, in the classroom, is a way students can come to know their worlds and understand their experience together.

Einally, the construct of student experience is central to Giroux's (1986) notion of critical pedagogy. The sharing of student experience in the classroom context provides an opportunity "to critique dominant forms of knowledge and cultural mediation that collectively shape the students' experience" (Giroux \& McLaren, 1986, p.234). The process of subjecting experience to critique provides students with the "critical means" to examine their own lived experiences rather than accept the latter unreflectingly. When students critically examine their own experience they are in fact examining the process of their construction of selves and the formation of their identities. Critical examination of experience involves a process wherein the teacher attempts to understand and affirm students's experiences and subsequently lead students towards an analysis of those experiences.

Scholar and teacher, Maria Ellesworth (1989), provides a vivid example of schooling as democratization. In 1988 Ellesworth found herself at a university that was "the focal point of a community-wide crisis provoked by the increased 
visibility of racist acts and structures on campus and within the community." At the time Ellesworth worked with students and faculty to develop an anti-racist course at the university. The course involved not only classroom discussion but also active interventions against campus racism in the form of marches and the production of media-based education against racism.

Ellesworth's attempts and the neo-marxist idea of public schools as democratic sites introduces a reconceptualization of the role of teacher. Teachers are envisioned as individuals who engage their students in democratic dialogue around their experiences in order to empower them.

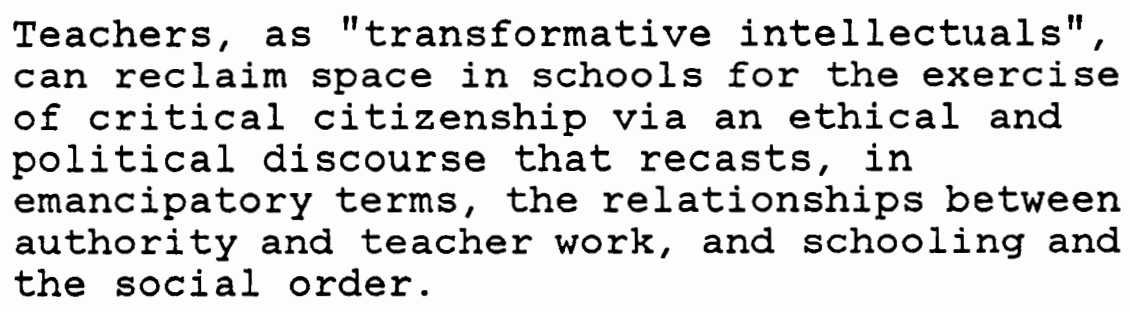

(Giroux \& McLaren, 1986)

\section{Key concepts \\ Transformative Intellectual}

The concept of "transformative intellectual" stems from the writings of Antonio Gramsci (1971) who saw all human beings as intellectuals who "think, mediate and adhere to a specific worldview." The importance of this insight is that it gives teachers and pedagogical activity a political 
quality (Aronowitz \& Giroux, 1985). Gramsci (1971) discusses the political and social function of intellectuals by using two categories: conservative organic intellectuals who are agents of the status quo; and radical organic intellectuals who attempt to transform social relations as they exist in a given society. The conservative organic intellectual, however, sees him/herself as autonomous and independent and neutral of any dominant social group, endowed with a character of his/her own. Within the context of the university, for example, the latter becomes the ivory tower where the intellectual can teach, serve on comittees and participate in scholarship maintaining an a-political stance.

Drawing on Gramsci's category of "radical organic intellectual" Giroux and McLaren (1986) derive their notion of teacher as "transformative intellectual". The transformative intellectual is quite clear on the political role $s /$ he plays as educator.

... One who exercises forms of intellectual and pedagogical practice which attempt to insert teaching and learning into the political sphere by arguing that schooling represents both a struggle for meaning and a struggle over power relations.

(Giroux \& McLaren, 1986: 215)

The transformative intellectual is critically reflective of his/her educational practice. Teachers as transformative intellectuals "take active responsibility for raising serious questions about what they teach, how they teach it and, and 
what the larger goals are for what they are striving" (Aronowitz \& Giroux, 1985). Reflecting on the concept of "teacher authority", for instance, may highlight the social and ideological role that teachers play in determining and legitimating certain forms of social life. The transformative intellectual is repeatedly faced with the question of what kind of society $s /$ he wants to live in, and subsequently, what kind of teaching supports the ideals of that society.

However, it is important to differentiate between the "critical intellectual" and the "transformative" "intellectual". The critical intellectual is described by Aronwitz and Giroux (1985) as an individual who is critical of inequality and injustice, but is often unable, or perhaps refuses, "to move beyond [an] isolated posture to the terrain of collective solidarity and struggle." The transformative intellectual, on the other hand, not only reflects on and analyzes various interests and contradictions within education and society but is also capable of "articulating emancipatory ${ }^{3}$ possibilities and working toward their realization" (Giroux \& McLaren, 1986).

The classroom is the site where the transformative intellectual begins to articulate and actualize democratic possibilities. Such teachers enable their students to engage in critical analysis and to make choices regarding what interests and knowledge claims are morally appropriate for a 
democracy. Toward those ends teachers become in Welch's (1985) words "bearers of dangerous memory". Students and teachers address "instances of suffering" that characterize present society so as to identify with people(s) who are marginal and exploited. Students become engaged in articulating other political alternatives and action that will hopefully remove constraints that restrict some citizens from leading decent and humane lives.

The conception of teachers as intellectuals and schools as democratic sites for social transformation may appear to some at best a naive vision, and at worst, a subversive, communist plot! There is no doubt that the transformative project has its problems. Transformative intellectuals cannot ignore that their practices are located within a "structure of possibilities mediated by cultural forms" (Connel1, 1983). Educational institutions are framed by certain traditions and values some of which may deter the transformative project. The university, as one example of an educational institution, has a very distinct culture defined in terms of space, time, organizational tools [texts, courses, programs] and products [publications, tenure]. Transformative intellectuals may find themselves at a telos of possibilities offered by the university in terms of financial support of scholarship, for example, and the cultural ideology of the university [tenure only on the basis of what is seen as "acceptable" scholarly interests]. The 
contradictions and resultant tensions for the transformative intellectual cannot be ignored as they raise fundamental questions about the transformative project. It is to these contradictions that we will now attend.

\section{Transformative Intellectual: Concept and Contradictions}

I mean by contradiction the existence of two structural principles within a social system, whereby each depends upon the other but at the same time negates it.

$$
\text { (Gidden, 1981) }
$$

Aronowitz and Giroux (1985) underscore the paradoxical nature of the position of the transformative intellectual in public schools and in universities. The three contradictions that we will discuss here are as follows: institutional values/educational values; student voice/teacher voice; rational subjects/meaning-makers.

\section{Institutional Values/Educational Values}

Sustained by the institution--university or public school--the practice of the intellectual is simultaneously rendered vulnerable by its institutionalization (McIntyre, 1981). The integrity of transformative practice/efforts may be corroded as the institution apprehends the resistance of the transformative intellectual and incorporates the efforts 
into mainstream university activities. Hence, transformative work becomes an example of "tokenism". When bombarded with accusations of racism and sexism in the university an official representative of the university in this study reminded the journalist that the university had a Women's Studies Program!

The role of the state cannot be ignored by the transformative intellectual. Practice can be influenced, and even determined, by interest groups. In Ireland the churches role in the state's organizational structure of primary and secondary schools, with clergy as school board managers and principals, is one example of such control. Teachers become the mediators of ideologies. Uncovering ideology, that is uncovering the relationship between personal practice and the political, is almost subversive in itself (Postman \& Weingarter, 1969); but it is only the beginning for the transformative intellectual who subsequently works towards changing undemocratic situations (Giroux and McLaren, 1986). Transformative intellectuals may find themselves envisioning quite different institutional structures and quite different [if any] roles for state and other interest groups. Lenntrichia (1983) describes the frustration of the intellectual who envisions because of personally stated educational values but is constrained by the values of the institution. 
...Paralyzed force, gesture without motion... ...feeling vaguely out of it, desiring change, but crushed, stifled, and enervated by the fear that the robust, active will may not succeed.

(Lenntrichia, 1987: 51)

\section{Student Voice/Teacher Voice}

The "active will" may emerge in the classroom where students and teacher reflect on the educational institutions and practices that mediate relations of class, race and gender discrimination. There is no doubt as to the political nature of such classroom activity. Liston and Zeichner (1987) make a clear distinction between the self as educator and the self as political activist. They explicate the distinction as follows,

... In the classroom the teacher is first and
foremost an educator and only (if at all) a
political activist. Teachers, as citizens
and workers, can and should engage in
political action outside the classroom,
especially that action which would create
better conditions for schooling. But
teachers as educators, must struggle to help
students find their own voice and develop
their own identities.

(Liston \& Zeichner, 1987: 122)

Berlak (1989) refers to the problem of educator and political agenda and the resultant source of tension in her paper "Angles of Vision". She explores therein her commitment to encouraging students to recognize and fight against injustice without imposing upon them "particular and 
potentially oppressive points of view". Her exploration of emancipatory pedagogy leads Berlak to question just how to encourage personal psychological or real change without violating student's personality and individuality.

By taking us inside the classroom Berlak (1989) raises the issue of pedagogy and its own inherent contradictions. Issues of power, authority and voice interplay in the classroom to create what Shor and Eriere (1987) term the paradox of pedagogical acts. Social relations, meshed in strands of race, class, and gender, are played out in the classroom with the concomitant problem of teacher-student power differential. Transformative intellectuals take charge by posing the questions their reality and their interpretation of the students' reality shapes the "dialogue". But is this "dialogue" in the transformational sense attributed to it by Shor and Friere (1987)? Clearly, dialogue presupposes that the teacher will not transfer knowledge as object, as a fixed possession; but the intellectual/teacher is still choosing the object to be critiqued and transformed be it "dominant mass culture" or some other concept. The teacher/intellectual may believe that the forces of class, gender and race discrimination restrict many people, this assessment may not be shared by students. An educational agenda that calls for action to undo injustice may be premature for students. Liston and Zeichner (1987:124) may be correct in suggesting that care and caution 
must attend this process of transformation within the classroom context.

\section{Rational Subjects/Meaning-Makers}

Ellesworth (1989) suggests that transformative efforts-pedagogy, scholarly discourse--are pervaded by an unhelpful reliance on "rationalism". In terms of pedagogy, it is assumed that students and teachers "can and should engage each other in the classroom as fully rational subjects". She continues,

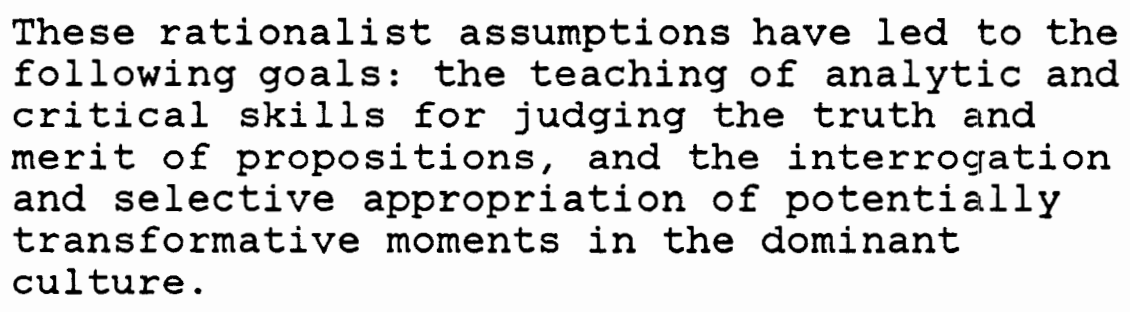

(Ellesworth, 1989)

The teacher enforces rules of reason in the classroom despite the ever increasing evidence that the idea of "the ideal rational person and the 'universality' of propositions have been oppressive to those who are not European, White, male, middle class, Christian, able-bodied, thin, and heterosexual". The efforts of the transformative intellectual may in fact be self-negating as certain voices are silenced and democratic dialogue is rendered impossible. Moreover, the problem of exclusionary rationalism is endemic to transformative discourse. "Democracy" is presented as the transcendent utopia--a non-negotiable absolute. 
Neo-marxists invite us to pursue democratic ideals together in solidarity, in the classroom and beyond. However, if Maxine Green (1988) is correct, solidarity removes absoluteness. Solidarity returns us to "ideas of relatedness, communication, and disclosure". In the context of conversation we share our experiences and try to make meaning from them. [We describe and inscribe our own worlds.] It may be in the very process of meaning-making that freedom is pursued. Individuals in the here and now take precedence over utopian visions.

\section{Women, the University, and Reform}

Universities have undergone reforms continually from the time of their origins (Winchester, 1988). Many feminist scholars would, however, agree that one aspect of the university has remained true to its original form--the male-centeredness of the institution in terms of substance and thought. In her essay, "Toward a Woman-Centered University", Adrienne Rich (1979) quotes from the catalog of one co-educational institution.

Brandeis University has set itself to develop the whole man, the sensitive, cultured, open-minded citizen who grounds his thinking in facts, who is intellectually and spiritually aware, who believes that life is significant, and who is concerned with society and the role he will play in it.

$$
\text { (Rich, 1979) }
$$


Simone Weil, denied entrance to the Ecole Normale Superieure, might have agreed with Rich. Weil writes that "she fell into deep despair over the loss of the transcendent realm only true men enter and where truth resides" (Weil quoted in Minnich et al; 1987). For centuries the academy had controlled access to education and to the definition and validation of reason itself" (Minnich et al; 1987). The early feminists of the nineteenth century [Rich calls them "the women intellectuals of the past"] were unperturbed by the male "trancendent realm" and assumed that the university, as an intellectual structure, was as viable for them as for their male contemporaries. Hence, the major issue in the nineteenth and early twentieth centuries continued to be the admission of women to the university for "intellectual training" (Rich, 1979).

Virginia Woolf was one of the first women to question this assumption. In "Three Guineas", Woolf reflects on the quality of the intellectual tradition protected by the university.

The questions that we have to ask and to answer about that [academic] procession. during this moment of transition are so important that they may well change the lives of men and women for ever. For we have to ask ourselves, here and now, do we wish to join that procession? Above all where is it leading us, the procession of educated men?

$$
\text { (Woolf, 1936) }
$$


Over the last century women have found their way into the university, though the presence of women is not represented equitably at all levels [difference in numbers of assistant, associate, and full female professors], nor are all groups of women represented (Minnich et al; 1987). It was not until the 1960's that echoes of Woolf's questioning reverberated. A different, and perhaps more "subversive", question emerged. The idealized notion of the university as the last bastion of "truth" was interrogated. Despite the female physical presence at the university, female, black and minority experience seemed to be missing from the academy--to study great American writers, for example, was to study great white, male writers. Disciplines dealing with woman's experience such as Family and Child Development were unheard of. Philosophy was dominated by an androcentric rationality (Young-Breuhl, 1988). Rich (1986) describes the reaction of women in academe to such exclusion.

When those who have the power to name and to socially construct reality choose not to see you or hear you, whether you are dark-skinned, old, disabled, female or speak with a different accent or dialect than theirs, when someone with the authority of a teacher, say, describes the world and you are not in it, there is a moment of psychic disequilibrium, as if you looked into a mirror and saw nothing.

$$
\text { (Rich, 1986:199) }
$$

Having gained access women now had to work at being truly present in the university, not by transforming themselves but 
rather by transforming the university (Minnich et al; 1988). How could the university itself be changed? "How best can we, as women, as educators, work on, as well as within the traditional academy?", ask Minnich, O'Barr, and Rosenfeld in their book "Reconstructing the Academy" (1988). Susan Hardy Aiken informs us that,

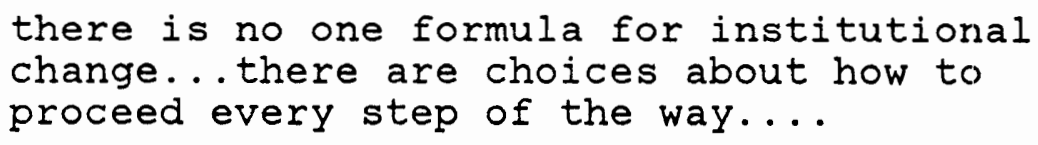

(Aiken, 1988)

\section{Feminism}

The word "feminism" first came into use in 1910 when women from various groups--blacks, immigrants, political radicals, college students--became members of the American woman suffrage movement (Cott, 1986). Cott (1986) explains that "feminism" was used to denote "the social awakening of the women of all the world" (Charlotte Gilman Ferkins) and the movement to readjust the social position of women (Inez Milholland).

Feminism is a social and political movement, revolutionary in character, that aims at a fairer redistribution of power (Spender, 1981; Mitchel1, 1986). The movement of women into the academy, and the attempts of the women to change the institution from within, have had as their founding principles those of feminism itself: that 
women are capable of agency, that they learn, think, imagine, judge, listen, speak, write and act, that is, the existence of an autonomous female subject (Delmar, 1986). Despite these abilities women have been subjected to the power both of individual men and of structures that men have mastered (Stimpson, 1986).

Eeminism should not be equated with the women's movement. "Feminism" and "the women's movement" are not co-terminous (Mitchell, 1986; Delmar, 1986). Certainly, feminism does exist in movements of and for women; however, feminism has and does exist as "intellectual tendency" without a movement, or as a strand within very different movements (Delmar, 1986)

De Lauretis (1988) suggests that feminism is best defined in terms of consciousness. Feminist consciousness is viewed as "a controversial political interpretation of female, socially constructed experience". Such an interpretation presumes political action. However, it may be exceedingly problematic to suggest that there is "a" single feminist consciousness. Delmar (1986) underlines the difficulty in "constructing modern feminism as a simple unity." There are many "categories" of feminism. Harding (1986) refers to fractured identities--women of color, cultural feminists, lesbian separatists, radical feminists, materialist feminists and post-structuralist feminists. 
Often dialogue between these groups is sparse, writes Delmar (1986). However, De Lauretis (1988) is more optimistic; she refers to the "debates" between different groups as "ultimately productive, because they sustain and nourish the practice of self-criticism, or better, perhaps, self-consciousness." Alcoff's (1988) discussion of the "identity crisis" in feminism facilitates a helpful insight into Harding's "fractured identities".

The "problem", as Linda Alcoff (1988) sees it, for many concept of feminism. According to Alcoff, feminist writers have articulated two major responses to the problem: the first response is that of the cultural feminists who maintain an exclusive right of feminists to define/describe/evaluate "woman". Eor cultural feminists, such as Adrienne Rich and economic institution but masculinity itself (Alcoff, 1988). For Rich and Daly both there is a female essence; patriarchy is defined in terms of the colonization of the female essence out of male envy. The solution of the latter state of affairs is found in the female rediscovering her own essence and bonding with other women. The second response to the problem of defining "woman" has rejected the possibility of definition (Alcoff, 1988). For the post-structuralist is no "woman" but rather "subjectivity." Post-structuralists critique,

The fundamental mechanism of oppressive power used to perpetuate sexism.... The mechanism of power...is the construction of the subject 
by a discourse that weaves knowledge and power into coercive structure...

$$
\text { (Alcoff, 1988: 267) }
$$

The coercive structure "forces the individual back on himself and ties him to his own identity in a constraining way" (Foucault, 1984). To define woman as having an essence is therefore to connect or tie the individual to her identity as woman and as such cannot solve the problem of sexism (Alcoff, 1988). The dialogue between the various "feminisms" continues... For the most part the conversation is carried on in distinct speech communities [Women's Studies Programs] within educational institutions, specifically the university.

\section{Women's Studies}

The institutionalization of feminism in the form of Women's Studies really began in the last half of the 1960's. Women faculty in higher education, began to develop courses that would facilitate reflection on "female experience and feminist aspiration" (Boxer, 1988:71). Florence Howe (1975), speaking of her own experience as a woman faculty in the sixties, points to the inspiration women like her received from both the free-university movement and the civil rights movement; the former served as models for organization and course development. The disciplines of English and History 
were two of the first to present courses on women probably because of the relative accessability of both disciplines to female scholars.

Boxer (1988) indicates that Women's Studies in the early years remained a "centerless, leaderless movement, marked by diversity in aim, content, and style." Nevertheless, Boxer is clear that Women's Studies represented a quest for revolution that was clear from the beginning

This education will not be an academic exercise; it will be an ongoing process to change the ways in which women think ard behave. It must be a part of the struggle to build a new and more complete society.

(Howe \& Ahlum, 1973)

Howe (1975) describes Women studies as the third phase in American women's struggle for education: in the early and mid-nineteenth century, there was an acceptance of woman's role of moral teacher and proponents of higher education for women argued on those grounds; in the second phase, attention was called to the "men's curriculum" and to the identity of male and female intellectual capacities; finally, in the third phase [sixties, seventies and eighties] far-reaching and provoking questions are being asked about the very nature of knowledge itself.

Lather (1983) sees the third phase of Women's Studies as both an "epistemological and political break with mainstream academe." Epistemologically, Women's Studies questions both the substance of knowledge and the process of knowledge 
production and legitimation. The introduction of the experiences and achievements of women to various traditional disciplines challenges the very substance of knowledge. Lather (1983) suggests that to consider unpaid labor as part of economics is to restructure the discipline of economics. McIntosh (1981) argues that such additions to the traditional curriculum underscore that the record of knowledge is not only incomplete but incorrect and its mistakes perpetuate the imbalance of power in society. Regarding process the new scholarship on women [Belenky, Keller, Noddings, Martin] questions the accepted distinction between subjectivity and objectivity. Hull and Smith (1982) ask: "What could be less objective than the totally white-male studies considered knowledge?"

Politically [though questions of epistemology are certainly political], Women's Studies is an educational strategy for change (Westcott, 1983). [However, Women's studies might also be interpreted as an institution's response to change agents.] Mazza (1983) writes that within Women's Studies "women can identify with an authentic sense of self, eliminate the conflict of living as "other" in male institutions, and engage in the [transformative potential] of ideological debate." Women's Studies becomes a "public space" where the morality of power is deconstructed and women claim their right to redefine themselves and their realities. 
Women's Studies has created "four interdependent models of presence" in the university that enact the political and epistemological agendas. Stimpson describes the models as,

...The interdisciplinary Women's studies
program itself, which offers a variety of
degrees; the study of women and gender within
a specific academic setting such as history
and sociology or even the intractable hard
sciences; mainstreaming, integrating the
study of women and gender within conventional
curricula and courses; and work outside of
the academy.

(Stimpson, 1986)

The Women's Studies Program involved in the present project offered a core package of four interdisciplinary courses labeled "Women's Studies" (Introduction to Women's Studies, Women and Creativity, Feminist Theory, and Women's Studies Senior Seminar). Completion of all four courses, in addition to two other related-interest courses based in different disciplines (Women in American History, Feminist Qualitative Research Methods, Gender Relations [Sociology], Women Writers before 1900) constituted a "Concentration in Wornen's Studies" for undergraduates. Participation of Women's Studies professors and students in conferences, rallies and marches constituted work outside the academy.

Many problems beset the new "discipline" both from internal and external sources: problems associated with political goals in academic settings, responsibilites to the women's movement, and the impact of Women's Studies on the university organizational structure. Boxer (1988) writes 
about a complete change of faculty in an early women's studies program at San Diego state, in 1974. Individuals feeling the tension between academics and activism resolved their personal dilemmas in various ways. Boxer (1988) mentions Jo Ereeman, a woman involved both in women's studies and the woman's movement, who decided that feminism was incompatible with scholarship but not with academic life. Mary Howell is described as having consciously compromised by applying traditional standards in her professional life and dedicating herself to community feminism and women's culture in her private life.

Many feminist scholars are still attending to contradictions in their work (Bowles \& Duelli-Klein, 1983; Treichler, 1986). Bowles writes that in some sense Women's Studies within the university is an internal contradiction; the university may be appealing to feminists because of the institution's commitment to cultural reproduction. Audre Lordre (1986) advises that "the master's tools will never dismantle the master's house" and challenges academic feminists to be aware and deal with its own contradictions. Behind a veneer of apparent coherence of Women's Studies and the university there may be further layers of internal tensions. Hutchinson (1988) underscores the conflicting ideals of the women's movement [action and sisterhood] and the incongruent power of Women's Studies professors/academic feminists as a priviledged group [with a lot of influence in 
defining the women's movement]. Florence Howe (1975) asks if Women's Studies is just a giant token of the male-centered university. "Parallel institutions" rarely change their hosts she writes. However, Boxer (1988) concludes that in the early 1980's the tensions and contradictions are being a basic belief that,

The orthodox university is still a vital spot, ...if only because it is a place where people can find each other and begin to hear each other. (It is a source of certain kinds of power.)

$$
\text { (Rich, 1979: 127) }
$$

\section{Consciousness and Social Change}

The struggle is over who will determine the forms of consciousness appropriate to the new age.

$$
\text { (Gramsci, 1971) }
$$

The term "consciousness" is used by neo-marxists in the sense of "political consciousness". Teresa De Lauretis (1986) defines political consciousness as "selfconsciousness"--the "political apprehension of self in reality." The struggle for the development of political consciousness in individuals may be inherently educational work (Lather, 1983). Transformative pedagogy attempts to effect a political consciousness in students.

[Transformative pedagogy] would develop and politicize students' own cultural expressions, identifications, and 


\begin{abstract}
resistances; it would attempt to encourage students within the context of their own race and gender, and... in their consciousness of themselves as members of certain social class, to develop coherent explanations for events--their own ideology. Political education would encourage them to use this ideology as the basis for social transformative activities.
\end{abstract}

Critical theorists and academic feminists focus on the possibilities of schools as sites for the development of political consciousness in individuals. The teacher's role is clearly critical for this project--the role of transformative intellectual.

Women's Studies courses may be an excellent example of the struggle to determine political consciousness in future generations. As counter-hegemonic ${ }^{7}$ work Women's Studies begins with a critique of the status quo in orcler to clarify contradictions that exist between received versions of reality [theoretical consciousness] and lived experiences [practical consciousness]. Academic feminists as transformative intellectuals go on to articulate ideological alternatives to patriarchal capitalism ${ }^{8}$ and facilitate collective/group work for change (Boggs, 1976).

The role [of the intellectual] is to develop the progressive forces of present history to become conscious of themselves, to transcend economist and privatized concerns, to aspire toward a substantive democracy, and to begin to see how social transformation can be accomplished.

(Lather, 1983: 40) 
The present inquiry was concerned with the lives of individuals whose educational practice suggested that of transformative intellectuals. Let us now consider more explicitly the directions that my work took.

\section{Objectives of the Inquiry}

There were three objectives in all:

1. To explore the lives of three academic feminists in order to assess the possibilities, limitations, and concerns arising out of their activity as feminist pedagogues/transformative intellectuals.

2. To inform the concept of teacher as transformative intellectual through empirical grounding in Women's Studies pedagogical efforts.

3. To examine the issue of representation in ethnographic research by rendering all description and interpretation, that is the creation of images of "reality" by the investigator, problematic in terms of control and oppressive relations between researcher and researched. 


\section{ENDNOTES}

1. Critical theorists, Henry Giroux and Peter McLaren refer to these reports on educational reforms as having played an important role in shaping educational policy at both national and local levels.

2. In the neo-marxist literature the term "new conservatives" is used to denote a political group made up of the old conservatives/right wing and the liberals.

3. Throughout this document the term "emancipatory" signifies freedom from the restrictions imposed by a patriarchal morality [See end note 4, Prologue]. Restrictions may include limited control of individuals or groups over their work, denial of access to debate, and obstruction of educational opportunities that would enhance an individual's quality of life. The word "emancipate", interestingly, is derived from the Latin "emancipare" which means "to give independence to a "son"! 
4. Alcoff and I, both, do not use the term "woman" as it refers to the patriarchal notion of woman as the objectified, fetishized "other", but rather as a adult female human being.

5. For further elaboration of the cultural feminist position see: Mary Daly's "Gyn/Ecology" (Boston: Beacon, 1978); and Adrienne Rich's "Of Woman Born" (New York: Bantam, 1977 )

6. See Denise Riley's "War in the Nursery: Theories of the Child" "and Mother" (London: Virago, 1983); and Teresa De Lauretis' "Alice Doesn't" (Bloomington: Indiana University Press, 1984).

7. "Hegemony" signifies the web of sociocultural mechanisms that develop, and sustain patterns of dominance and submission, according to Gramsci. Examples of sociocultural mechanisms are educational institutions, the family, and bureaucracy itself. Counter-hegemonic work involves a political perspective on the individual's or groups's lack of power and enactment of resistance to hegemonic norms towards the end of structural change. 
8. Patricia Lather (1983), drawing on the work of Natalie Sokoloff's "Between Money and Love: the Dialectics of Women's " "Home and Market Work." (N.Y.: Praeger, 1980), defines patriarchy as "the socially sanctioned power of men over women operating at material, ideal, and psychological levels in both the private and public sphere." Capitalism as an economic system based on private ownership of the means of production, distribution and exchange of goods/property is the material means by which patriarchy is sustained. 
CHAPTER 2

CASE 1

\section{Introduction}

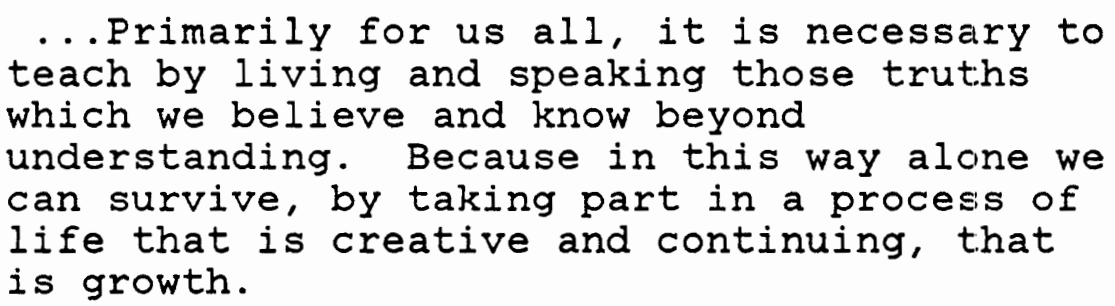

Audre Lordre

Audre Lordre advocates the transformation of silence into language and action; Muireann, an academic feminist of Case 1, tries to live and teach the transformation. Muireann is a creative writer whose work is autobiographical in nature. She uses writing as a means of breaking the silence of generations of women, to whom she refers as her "mothers and foremothers". Muireann's commitment to "voice" and particularly to the articulation of women's voices in writing is transferred to the classroom arena, wherein Muireann encourages her students to break the silence, to take voice by talking and listening, reading and writing. When students and teacher take voice, they tell about their experiences. When they talk about their experiences, they construct 
stories or narratives in a social context. Muireann's course Introduction to Women's Studies represents an exploration of such personal narratives.

In an attempt to understand Muireann and the classroom process which she facilitates, I explore four characteristics of narratives of experience as they are played out in her classroom. The four characteristics are as follows: the personal aspect; the social dimensions that dernand trusting relationships and a "safe" environment; the performance of meaning that develops as participants construct personal stories together; and finally, the discourse in which narratives are contextualized in this introductory course in Women's studies.

My exploration of the dimensions of Muireann's narrative approach to pedagogy will hopefully shed some light on Muireann's efforts as academic feminist, writer and teacher, to "break silence", as well as her students' response to those efforts.

\section{Narrative as Personal - Vignette}

The momentum of the Eall semester gathers itself and the month of October is well underway. Introduction to Women's Studies proceeds as usual in Room 400 on Monday, Wednesday and Friday mornings, beginning at ten o'clock and finishing fifty minutes later. 
The day is Eriday. I feel a little weary as I climb the four flights of stairs to reach the fourth floor of Walker Hall. In front of me on the staircase is a wornan.

I recognize the slight figure to be that of: Muireann, instructor of Introduction to Women's Studies. She is about thirty years of age. Dressed in a long floral, cotton skirt and white laced cotton blouse; she picks her steps slowly but deliberately. As I catch up on her on the stairs she looks around and smiles, seemingly glad to see me. I notice that her face, framed by shoulder-length black hair, reflects the whiteness of her blouse. Her blue velvet ribbon, serving as a hair-band, matches the embroidered blue satin of her Chinese shoes. I am reminded of Naomi's comments on Muireann's quiet femininity, not at all "the macho-construction worker" feminist that Naomi had initially expected.

Now Muireann gives me her full attention as we walk side by side, still struggling breathlessly with the multitude of steps. "How are things going?", she asks softly. "Oh, fine", I answer rather reticently, wondering if I should tell her my recent news from home concerning a death in my family. Does her question indicate genuine interest or an attempt to be pleasant, I wonder. I decide to tell her my story and feel reassured by Muireann's brief by empathetic response.

She begins to talk to me about the reading for today's class--Maxine Hong Kingston's, The Woman Warrior. Muireann, 
a creative writer herself, shows a deep interest in and concern with women's writing. She tells me that the autobiographical aspect of Kingston's book is fascinating to her. "When you write down your life on a page, your life takes on a life of its own", she says, speaking as someone whose own writing is autobiographical. Our conversation is interrupted abruptly by the noise of voices coming from a distant classroom. By this time we have reached the fourth floor; the noisy classroom is our destination. It strikes me that a month ago we wouldn't have heard such sounds from the confines of Room 400. I have heard Heather, a sophmore student in Introduction to Women's Studies, refer to the atmosphere of 409 as "highschoolish"! The noise today seems to validate Heather's impressions.

The desks are already in a circle, not as big a circle as on other days, however. "A 'Eriday' class", comments Muireann as she calls the roll, from her place in the circle (her back to the blackboard). I find a seat in the circle also, with my back to the windows so as to avoid the blinding light of the sun. I count eighteen students present out of a possible thirty or so; yes, this "is" a "Friday" class. As Muireann gathers her book and notes the chatter continues but in softer tones, confounded by the noise of campus traffic down below.

I take a quick glance around the room and survey the by-now-familiar faces of the sophmore and freshmen students. 
On first glance, the class appears to be predominantly white and female, the majority middle-class and coming from the northern part of the state. On further inquiry, however, I have found that difference defines this group---sorority sisters; students from rural areas in south-western part of the state; "D.C. girls", as Naomi terms them, from Washington D.C.; African-American women some of whom are sorority members; and two male students, one white, the other black. The underlying commonality of all students is their youth--no one is more than twenty years old.

I notice that Donna, an out-spoken lively participant is present, smiling and chatting to Dorothea, another African-American student. Dorothea sometimes seems hesitant to speak in class, which may have something to do with the fact that her boyfriend Rob is also taking the course. Rob is not here today. In fact, he rarely comes these days. When he does, he's silent; unlike Tom, a fraternity member, who comes on a regular basis and participates orally from time to time.

Sue raises her hand to get Muireann's attention; she has a concern regarding the research paper that's due in a couple of weeks. Sue, once described affectionately by Muireann as having "swallowed feminism whole and not digested a morsel!", is popular with both students and teacher. Sue, always indignant of women's oppression, always willing to express an opinion, always ready to argue her point passionately, is 
a sophmore student in English and Education. Muireann seems ready to begin and she explains to sue that all information regarding the paper on a woman in history will be furnished next week.

Muireann begins, "The Woman Warrior" is one of my favorite books". Naomi interjects, "Oh, I just remembered. I wanted to tell everyone that I found a wonderfully helpful book in the Women's Studies Library. It's called......". Naomi is a vivacious, blonde woman from Kentucky. Highly spontaneous, she is never reticent when it comes to discussion; by now I have heard numerous stories in class surrounding her family life in the south, and her college experiences in the College of Engineering. Muireann thanks her for her helpful information and makes a second attempt to begin. "It is one of my favorite books...but I shouldn't say that because you may not like it. It's not: autobiographical according to Kingston but I think it may be in some senses. It's an important book for me in terms of my own writing. Last year when Kingston came to visit this university I spoke with her and got her signature. I could talk for ever about this book but I want to becin with you... what was your sense of this...let's begin with the first chapter: "No Name Woman".

Today Muireann doesn't ask whether we've read the novel about Chinese American life as experienced by one woman--Maxine Hong Kingston. Instead we immediately begin 
to discuss Kingston's story about her aunt, who, unmarried and pregnant, kills both herself and her baby, after giving birth to the child in a pigsty. The story takes place in China at the beginning of the twentieth century. Donna is the first to reply to Muireann's invitation to respond to the text, "It made me very, very angry. I thought that it was very good that the aunt committed suicide." Muireann seems surprised, "You were happy that the aunt died?", she inquires. Donna, feeling that she has been misunderstood blurts out, "no, no". Muireann reassures her, "I'm not making fun of you...really. In literature women that are pressured often resort to suicide, and this course of action is often portrayed by writers as a "good" way out. You were going to say something", Muireann addresses another student, Sandra. Sandra offers, "I didn't understand the birthing in the pigsty." Before Muireann has a chance to answer Marian explains, "Oh, that was meant to confuse the Gods. Many people believed at that culture that the Gods would punish a woman like that--an unmarried mother." Muireann affirms Marian's response, "Yes, the notion of confusion is important. If you have ever walked in China town the bustle of the streets tends to confuse you and also silence you." Turning now from sandra and facing the rest of the students Muireann invites, "Did you have any other reactions?" Marian speaks up. "I find it interesting that the woman takes all the blame for the pregnancy. The 
villagers seem to see the "problem" as her fault entirely. What about the man involved?" Naomi answers, "It was the woman's choice to say nothing. She decided this because he was a big wig in the the town." Muireann questions, "Why not uncover him?" Naomi replies, "Well, like I said, he was a big wig in the town and if she said anything she would distort the image people have of him..." Her voice trails off as Muireann addresses the rest of the class, "Are you admiring women for keeping this thing to themselves?" Sue, the self-described feminist, seeming agitated with the woman in the story, says, "She blamed herself for the whole thing." Samantha, as if to keep the record straight reminds us, "Yes, but the narrator, Kingston, she doesn't tell us that, nor does she blame anyone for the tragic suicide. She seems intent on giving a well-rounded story." Muireann replies, "Yes, Kingston gives us a number of stories, she's playing with ideas..but there is one consistent thread through stories... we don't know the man involved.... Given this story of "No Name Woman", a woman left behind by a husband who emigrates to the United States, and who is violated by some unknown man in the village,...can this woman ever know love?" Samantha suggests that No Name Woman was expected to stay at home in China when her husband left. "She is also expected to accept this and live with the situation", Samantha adds. Muireann points out that it may be a case of an individual surrendered to her family. 
Muireann turns to face Angela. "In the Jim Baker trial Tammy, his wife, was requested to be a character witness.. What does all of this tell us about what women are valued for?" Donna, in a rather exasperated tone exclaims, "They're there for their husbands." Marian reenters the discussion at this point, "I believe that in this book that it's different. Women are not there simply for their husbands; they are there for their families. Women act as anchors in that they keep family ties closely bound." "Is there anything else that they are valued for? In this book, what is the role of female children in Chinese society?", asks Muireann. Sue, as indignant as ever, "They give them away". Muireann corrects, "They don't give them away. They pay to have them taken away. Remember the grandfather and the exchange of girl children for boy children." "That's crazy!", blurts out Donna. The discussion continues on the issue of devaluation of female children. Students seem to be 1 istening to one another but no notes are taken, I notice. Though not all students speak a quiet interest hangs in the air.

"What kind of characteristics do we value in women?", inquires Muireann. Angela and Sue supply brief answers respectively--"passivity" and "gentleness". Muireann reminds us, "Aren't women valued for not being selfish? No Name Woman never tells her story; she never discloses the name of the man who is the father of her child. Perhaps he 
was a worker in the fields who made his expectations clear and warned her not to tell. And so she met with him on a regular basis as she worked in the fields because she has learned that she must do as she is told. But she never tells. It is trained into women not to give voice to their experience. "No" "Name" Woman. She has no identity. Today, women like their jobs as ways of self-definition."

Muireann continues to question, "What else is going on here? Do you remember the part where we are told by Kingston that her mother warned her never to speak about No Name Woman, her aunt, in front of her father?". "There is an idea here that there is knowledge that we must protect men from...", Muireann tells the students. One student replies that usually women don't talk about issues of sexuality in front of men. Muireann questions in response, "What does the narrator associate with sexual maturity or menstruation?" The same student replies, "Shame".

Muireann begins a story, "I remember my first menstrual period. It had to be such a secret. I didn't want anyone to know. It was as if something awful had happened to me." Muireann's story is responded to in silence. Muireann exhorts, "Has no one felt like me? I'm always saying things and I think later on, "Why do I say these things?""

Rose begins, "When I began having my period I hated going to the store to buy sanitary pads or tampons. I mean once a man stood behind me in the line to the cashier and I was so 
embarrassed." The students laugh in chorus and empathize with Rose with groans of agreement. Samantha recounts a story of buying a bra, "Once, I went to a department store because I wanted to buy a bra. I was still in Junior High so I really hadn't gotten used to this kind of shopping. Anyhow, I explored the racks and rails of underclothing feeling "safe" and hidden from anyone's view. Eventually, I chose one that I liked and I walked shyly to the cashier's desk. I almost died. Who was standing by there but my History teacher! I felt so bad. I didn't know what to do with the undergarment in my hand. I couldn't think of a way to hide it. I knew she saw my embarrassment because when she looked at me she was smiling to herself. I hated that day." Muireann is reminded of her own "attempt to hide", "I know how you felt. When I went to buy a pregnancy test substance in a store I also bought a magazine so that I could hide the box under it!" "But you know it's true," a Sandra interrupts, "I still feel like Rose when I have to buy tampons. Last time I did I felt that the two men standing in the line behind me were watching me. It's funny because it's so natural to have a period." Muireann agrees, "Yes, it is natural. But it's just like my own brother's reaction to breast milk, which he describes as "women leaking" and defines as "gross!". Everyone laughs at Muireann's candidness. "I know I'm out-spoken.. so is my mother. But what is natural takes on other terms," Muireann adds. Sue 
agrees. She and another student contribute similar stories from their personal experience.

By now the fifty minutes is almost up. Muireann explains, "Time is nearly gone. It's important to talk about these things. I feel everyone is like me. We have a common basis. In my mother's time no one talked. Let me fill in a few things on the book: Maxine Hong Kingston, on being told not to speak of her aunt, No Name Woman, writess a book. So in the face of an injunction to silence the book is written and published. As such it is an act of disobedience, similar to the act of her aunt--"she couldn't be pregnant, her husband was away." In this chapter we see the mother telling Maxine the story of No Name Woman and then Maxine as our narrator--mother and daughter act as story-tellers. Women cannot hide; if you're pregnant you are intimately connected to your body in a way man is not. As the writer, kingston, begins disobeying her mother, we see what is, distinctly, a woman's problem--the mother-daughter relationship. Okay, make sure you've read the next two chapters for Monday."

Marian approaches Muireann as students gather their books and bags and prepare to leave room 409. "Are you feeling better?", Marian inquires. Muireann replies, "I think so. I hated having to cancel class like that on Wednesday but I felt very weak". Muireann, who has stood up from her chair, stoops to sign an "add form" for another student. She gathers her books and walks out with some remaining students 
still chatting about "knowledge that men must be protected from". I join the group at the rear and we begin to descend the staircase to the first floor.

\section{Narrative as Personal - Exposition}

\section{A Sense of the Personal}

Muireann is a writer and a story-teller. She sees her writing as one of those things which is "closely connected" to who she is as a person, a human being. During an interview, Muireann tells a story about being asked to talk about herself as a writer.

I guess it's a funny sort of thing cause it
reminds me of the first time I was
interviewing to be a writer in residence
somewhere and they wanted me to talk about
myself as a writer, which is one of the
things most closely connected to who I
am, ... and my mouth turned dry and it was
realiy hard to talk about something that I
do that is so intimately connected to who I
am. and ...eh..they would say, "oh well. I
really liked this story..tell me about it."
And I really couldn't and I felt really
stupid coming out.... And I think it made
me highly aware of...notions of talking about
myself because of writing autobiographically
and so I suppose continually inscribing an
idea of self, a sense of self on the page.

For Muireann, the notion of talking about oneself, and articulating one's experiences in writing, is deeply connected to "inscribing an idea of oneself", or the act of self-definition. Muireann believes that in order to define 
oneself autonomously, one must have opportunities to tell one's stories, to create and share narratives of experience. Muireann concerns herself specifically with the experience of women which she feels has long been hidden. Within the realm of women's experience she is conscious of "problems that haven't been articulated because they're taboo. She expresses it as follows,

... Lives that haven't been articulated and problems that haven't been articulated because they're taboo... because you're not supposed to speak about your sexuality or your longings or your angers or your frustrations or. because they all go against the ways society would like to define you.

To articulate the desires and frustrations of women is to make public that which has been relegated to the private. In a process of self-expression, women begin to define themselves on their own terms, rather than be defined by others. In The Woman Warrior, No Name Woman never tells her story; she never defines herself in any sense, Muireann tells her students. Hence, No Name Woman is defined by others--her family and community--in terms of her role as a woman who must obey.

Muireann seizes an opportunity for her own selfunderstanding in her own writing, which is largely autobiographical. Her writing deals with the notherdaughter relationship, which she believes to be the most intimate of relationships. The intensely personal aspect of Muireann's writing is inescapable because, as she 
acknowledges, women's distinctive experience as women occurs within the personal, particular and emotional sphere.

Muireann's writing process is reflected vividly in her classroom process. Below, she talks about the contribution that she as a writer can make to the classroom process.

I mean a lot of people in the academy would say that scholars bring what they do to the classroom..but writers, you know, what do they do? But... I'd say that my writing is very much a part of who I am as a teacher and that I learn from it and I learn from iny teaching and it's part of a cycle.... I don't know maybe the most dynamic teaching comes when you are fully engaged in the art of self definition... and it has to do with what you do and carry it into, not in a selfish way, ... where you're saying, "Me. Me. Me." But this engaged process of figuring out place or sense of self or who you are in relation to the world or to what you are studying... It seems to me that my most dynamic work comes from being able to bring that in a coherent way into the classroom and certainly it's something that I am concerned about... when I'm writing... you know, I'm taking voice....

By sharing personal stories, Muireann models a process of "figuring out a sense of self", in the classroom. Within the classroom context her personal and professional project meet: Muireann continues to engage in her process of self-understanding by articulating her personal stories publicly, while encouraging students to do likewise. The purpose of the course, Introduction to Women's Studies, becomes for students and teacher, a process of figuring out a sense of self, and an understanding of the assumptions on 
which they base their lives. Muireann describes the process by applying the quilt metaphor that she uses in her writing.

It's like stitching something and unstitching it and stitching it again and going over the same piece of fabric...

\section{A Private-Public Tension}

As students and teacher engage in the process of selfunderstanding, Muireann finds that her own personal life experiences become the pieces of fabric that must be stitched over and over again, as the "content" or "text" of the classroom discourse. Muireann firmly believes that she must be willing to share her personal life experience with her students. Her stories tend to evoke personal stories from students. Muireann tells the story of her first menstrual period and thereby leads other students to share their stories of female sexuality. Not only do students discover that women as a group share their experience but also they come to realize that a common thread joins stories--"female" knowledge is hidden from men. The stories no longer reflect the experiences of individuals but the common experience of a group--women.

Muireann struggles with a private-public tension as a result of sharing her personal experience. Wishing to maintain her privacy, yet feeling, ironically, that her ability to share the personal with her students is one of her 
strengths. It makes her vulnerable; nevertheless she finds herself sharing "over and over again".

I think I'm finding more and more to my surprise, because I think I'm a warm and open person, that I'm an extremely private person... How can you be a private person if you're comfortable using a sense of who you are and your passion for things in the classroom in order to make a point..

Muireann's stories serve as models of self-exploration for students. After a two-week illness Muireann returns to class looking noticeably thinner, speaking even more softly and tentatively than usual. She begins class by telling the following story.

I have been sick. I am sorry for not being here. I have to take it easy for the next few weeks. I will have to go home and lie down so call me. I used to have a "Brownie" professor... sloppy, soft, disorganized... I was critical toward her.... I've thought of her this week.... I found it difficult to ask for help. I seemed stubborn to my friends.... Large parts of me had to be missing for me to be your teacher, to be a real professional that your other life has nothing to do with it. other parts feed our professional selves. Now I feel bad about thinking like I did about Brownie. Cinderella's sisters cutting off toes...we can't cut off our vulnerability...t to be. You may find in your life...you'll find that to be a mother...it's not effortless... we try to make it look easy.. you have to pay. When we look at it that way... we might see how mothers work...but we prize what we pay for.

Muireann describes here her attempts to be "superwoman"-- the perfect wife, mother and professional. She finds it extremely difficult and stressful to the point of becoming seriously ill. Muireann uses her experience to reflect on 
her expectations of herself, expectations meted out to women by society. The implication of her story is that women should be able to fulfill multiple roles perfectly, with little effort on their parts. Muireann's own experience contradicts this as she finds that "you have to pay". She remembers "Brownie" who no longer seems a pathetic figure but just another vulnerable human being. By telling stories Muireann hopes "to introduce students to alternative ways of seeing things". How do students respond?

\section{Personal Narrative and Student-Process}

Students are attracted by a course that involves the sharing and exploration of their personal narratives. However, the process is not an easy one for them.

June decides to take Introduction to Women's Studies because she knew beforehand that many of the issues would be of interest to her and relate directly to her experience.

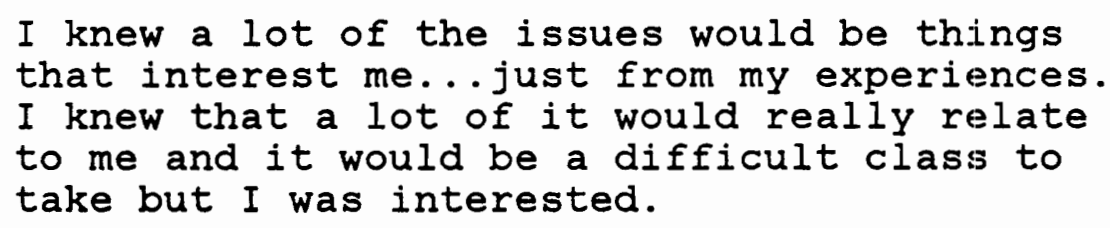

When asked to elaborate on her feeling that the course might be difficult, June explains, "Because some of the things we talk about are things that I'm having to deal with right now." It is difficult for June to open herself up to an elaboration of her personal life. June continues, "You open 
yourself up to some things that are hard to...hard to handle."

June's explorations, in Introduction to Women's Studies, lead her to reflect on the Catholic doctrine with which she has grown up. There seems to be an unresolvable discrepancy between her life [in terms of her religious beliefs] and the classroom discourse [advocacy of a "belief in women"]. June discloses that,

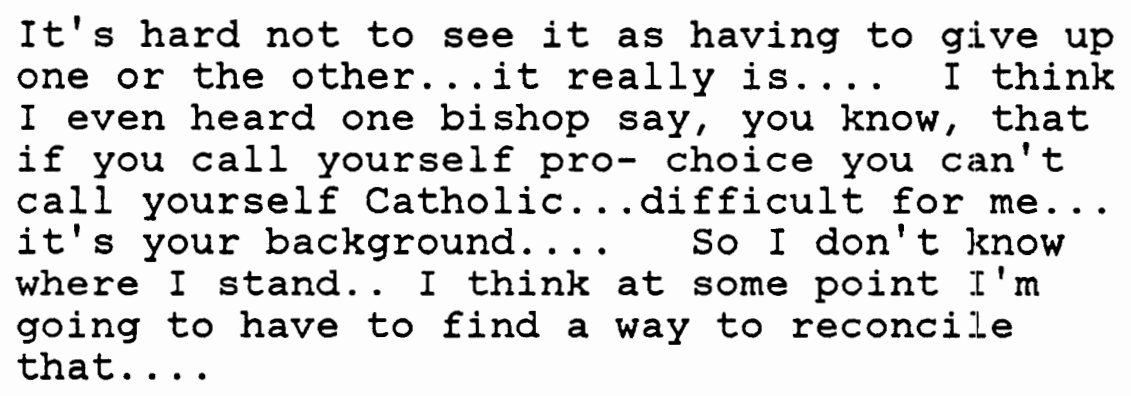

June realizes that the "story" with which she has been raised is not the only one available to her. The "one"-Catholic--story that has reigned supreme is now one among many alternatives. The tension, contradictions and ambivalences, between and within the Catholic and Feminist "stories" bother her, and "It hurts", she says.

The tension between apparently contradictory beliefs is understood or heightened within the social real.m of the classroom. June finds herself in conflict with other students whose value systems differ from hers.

And it's hard enough trying to understand yourself and then when you're sitting in a classroom and you're reading these things all semester and you're listening to other people in the room who maybe haven't had some of the 
same experiences so they're not coming from the same position.

Feelings of vulnerability continue for June as she feels "things getting a little bit too close" for her. However, she finds some sanctuary in her writing assignments. Writing about her personal life is "hard" but worth the effort, she says.

And towards the end when I was looking over it last night before handing them [journal entries] in, I was thinking that this is something that I would like to continue, you know, because it helps a lot....

....there's something very powerful about going back and reading what you have written and I don't know.. it just makes it important.

June's writing may exemplify a process of embracing contrary religious and feminist beliefs as she explores them simultaneously in her writing. Toward the end of the course she concludes, "Maybe being a feminist is having different sides of yourself or something." Additionally, though writing about the personal is difficult for June, she finds the use of first person "I" an empowering experience. She finds a sense of herself in writing a research paper about a woman who might act as a role model. Muireann encourages the students to use their own voices in the paper.

Write as you feel the need to express it. Your own voice may not necessarily fit into a certain formula.

The response to this open format was one of relief and delight for June. 
The paper was really great! [She laughs] I really enjoyed that. I was amazed.... .... So writing the paper when she said, "I'm not going to give you any specific format... I'm not going to tell you how to write this paper... and being able to use the first person in describing why this person is important to me was, it was really a fantastic experience. I actually had more fun writing that paper than doing the things that I've done in my other classes. There's something about being able to say in a paper, "this is how I feel that makes it...to me it makes it my work.

The ability on June's part to say "I feel", to articulate her own personal response to the subject of the paper, facilitates her ownership of the written work. A sense of what constitutes "my work" begins to develop for June; a sense of herself. A connection between "self" and "work" is forged, mirroring Muireann's own process of self definition through writing.

\section{Literature as a Vehicle of the Personal}

Literature as text is used by Muireann in Introduction to Women's Studies as a path to understanding one's life and oneself. Muireann explains, in an interview, how she wants her students to "walk with the text", to "read as listeners", "to get inside its skin in a sense and to understand selves in terms of it [text], from that "inner position".

Muireann uses pieces of literature that she herself identifies with in a personal manner. The theme of "placelessness", explored in the context of Maxine Hong 
Kingston's The Women Warrior is one example. Muireann talks candidly about her sense of placelessness during an interview: growing up as part of an upper middle class family with very little money; being born in Boston but having moved about from place to place; an inability to find a religious doctrine that her set of Christian beliefs might fit. Muireann describes herself as not being from "any one place", of continuously feeling "inside" and "outside" of groups. She choose texts that reflect the theme of "placelessness", and as such her own personal struggle. Muireann says,

I teach books where you know there's... ceremony where a young man who is a half breed indian tries to figure out where he belongs; or Beloved where a woman, who is not a slave anymore, is trying to figure out where she belongs or The Woman Warrior trying to figure out what her place is....

The Woman Warrior, by Maxine Hong Kingston, is embedded in the personal experience of the author and as such the text is highly representative of the texts used in the course, Introduction to Women's Studies. Muireann leads students through a discussion of the first chapter, "No Name Woman", questioning and probing students for responses and reactions to the main character--a Chinese woman. The discussion moves from questions like "What was your sense of this?" and "What about the man involved?", to questions framing broader issues such as, "Are you admiring women for keeping this thing [experience of an unwanted pregnancy] to themselves?" and ultimately, to the telling of stories about instances of 
"hiding" in the participants own lives--"I remember my first menstrual period." In this manner, using literature, Muireann skillfully leads students to an articulation of the personal.

Students feel that they should respond to text in a personal way.

I think that a lot of things should be responded to in like a...formal manner and then somethings you want a few personal,...most of them should be personal.

Naomi differentiates above between the form more typical of university courses--"formal"--and the newfound "personalized text". Donna comments,

...And then in my journal.. I don't know if everybody else writes in it the way I do. I don't write about what we are reading so much as how it has...applies to me personally or just the kinds of things that it made me realize and things like that....

Ironically, although texts facilitate students' selfdisclosure, they also serve to facilitate discussion of difficult issues without exposing personal lives to criticism and scrutiny. In this sense, reading texts acts as a safety measure for students like sue, for example, who show an unwillingness to share the personal. Sue couches her unwillingness to share the personal in terms of "what you don't speak about", that is, those subjects that are taboo for public conversations. Sue differentiates between personal experiences, those issues "close" to you and "opinions" about reading material. 
... I think talking about the book is different than how you feel. .... When you're talking about the book..it's ...I mean you can say things about the book but distance them from yourself rather than when you're talking about something like "mother-daughter" relationships anything you say could be related to you.... I mean family...you kind of keep that a sort of secret...your life and your homelife because you don't want people to know that you've got problems and stuff....

For Sue, it is safe to respond to the readings as she never has to go beyond the text itself to a public exposition of her own life. However, Sue can still make connections to her own life and explore her personal experiences in terms of the literature but in a more private setting.

The personal lives of women are evident in Muireann's classroom on three levels: the teacher sharing her stories; the students telling theirs; and the stories of authors such as Maxine Hong Kingston are read and discussed. The pedagogical method of Introduction to Women's studies is personal narrative and consciousness raising takes the form of story-telling. However, as students and teacher speak their stories around themes such as motherhood, marriage, menstruation they may be reinforcing what society construes as "feminine" issues. When classroom discourse centers on the concept of woman as embedded in old, cultural frames, it may be re-emphasizing the significance of that which should not be important--gender (Alcoff, 1987). 


\section{Narrative as Social - Vignette}

Someone once said that Women's studies courses always got the worst rooms in the university. Well if so, it happened again! I wasn't a bit surprised when Muireann announced to the class that she wanted to change the room. The pinned-down desks in straight lines facing a teacher's platform, desk and blackboard, seemed reminiscent of Dickensian Hard Times and authoritarian tones and processes.

Today, August 22, 1989, Muireann is standing in front of the blackboard. She begins, "It is extremely difficult to facilitate discussions in a room like this. However, there seems to be a problem in finding another room. I want to give you some advice. I can't enforce this but if you sit in different places everytime you come to class, I think you'll get to know each other and feel better about saying what you feel. Sometimes I say things in class that make me feel naked and vulnerable; I go home wondering why I said that. I recommend this as very useful."

At this juncture, Muireann moves toward the door behind her and closes it. She then walks to the door at the other side of the blackboard and closes it. Apologetically, she explains, "I know it's hot in here but...." she trails off. There is no need. for her to continue because students can hear the mumbled strains of another class in process directly across the hall. As Muireann returns to her chair at the top 
of the room she invites the students, "I'd like for you to take a minute on paper and describe yourself; how you see the way you are."

Without any verbal response the students begin to write. Silence pervades the room. Muireann sits down and looks about her. Intermittently, she coughs rather loudly, and turns very red. Now she breaks the silence with, "You might also want to include something you might be but aren't, something you wish you were like."

There is silence. Some minutes pass. Muireann interjects again, "Finding an apt way of describing yourself may be helped by use of similes." Students continue to write as Muireann stares directly in front of her, over the students' heads, toward the window at the back of the room. "Just another minute or so," she says after five minutes of writing has passed.

Now ready to begin, she says, "Let's start with--is it easy to describe yourself?" Donna replies, "It is difficult to describe yourself as you wonder whether what you think of yourself is what you really are, and you keep considering what other individuals might think of you." Muireann responds, "Are you saying then that an honest description takes account of another's description?" Donna answers in the affirmative. Other students agree with her.

Is there a place where you are cleansed from what other people think?", Muireann inquires. "Absolutely not!", says 
Samantha adamantly, "there are just many different sides to different people." Muireann retorts, "Is there any one side of you that is more genuine than another?" Rose, sitting at the back of the room, confides, "For the past five years I have never been genuinely... I I mean fully myself with my parents." Samantha responds to Rose, "I am surprised to hear that. My parents are the two people whom I feel I can be myself with."

Muireann addresses Rose, "Look what they are missing". Muireann and Rose exchange smiles. Muireann goes on to explain to the class, "There are composite pieces to us, different sides that we show at different times when we think it is appropriate. But this doesn't make us fake; it just makes us different."

Dorothy comments, "I am different with my boyfriend than I am in class." Muireann's response, "Good! Good!", is drowned in the laughter of students. Dorothy continues undeterred, "There are times when you want to act honestly and be yourself but you can't because of the context." Muireann questions her, "So you could act honestly but you realize that there might be repercussions. What kind of situation?" Dorothy replies, "Well, in a job situation, for example. Even for a summer job, I went for an interview. I couldn't dress the way I wanted to or would usually. I had to be careful about the way I pronounced my words. I had to say the "right things". You know...." "Because of fear of 
rejection", Muireann completes the sentence. "I can remember a story similar to yours that a friend of mine told me. In my field, English, there are meetings or conventions where a lot of interviewing goes on in hotel rooms. My friend had been interviewing all day--mostly with male interviewers. (My field is still a patriarchal one.) Anyway, on arriving at the last interview she was exhausted and she spoke honestly when she entered the hotel room on finding three women there to interview her. She said, "Oh, how wonderful, there are women here." With this comment she opened up the whole interview. I suppose I wonder if we dare risk saying who we really are. This makes defining yourself hard."

"How much does your sense of gender have to do with defining yourself?", Muireann inquires softly, as she walks about the room. Beatrice, an African-American woman replies that when males define themselves they probably use words like "ambitious", "strong", "non-emotional"--just like the cultural stereotypes we have of men. Beatrice continues, "But my own description of myself emphasizes the emotional side." Muireann probes, "You seem to have thought about culturally feminine things?" Beatrice replies, "Yeah, things that are looked down on in our society."

Muireann returns to her original question, "What is the influence of gender on writing?" Samantha insists that her piece was not influenced by her gender. "Would you like to read it aloud to the class?", Muireann invites. Samantha 
agrees and everyone sits and listens. As Samantha finishes, Sue raises her hand to speak. She says, "I think that the piece was very influenced by the female gender of the writer." The use of words like "sensuous" is indicative of her gender. If she were a man she would probably use the word "sexy". The remainder of the class seem to be in agreement with Sue, expressing a quiet chorus of "Yes". "Doesn't "sensuous" mean "sexy"?, Muireann asks. She replies promptly that this may be the case but it is not the way society defines it. She explains further, "Sexy" is for men but "sensuous" is for women."

Muireann invites Angela to read her description. This African-American, engineering student reads about her wish to be a female goddess who could help other women be what they wanted to be. She continues, "I like being with my own kind." Almost immediately on completion of her reading, a student blurts out, "What do you mean that you like being with people just like yourself?" Angela explains calmly, "I mean people who are like me, who like to do the same kinds of things, and who act like me."

Muireann choses to comment on the ambition to be goddess-like, "That's a good ambition". "Anyone else?", she invites other students to share their descriptions but to no avail. Muireann breaks the silence and speaks by speaking about her own writing. "It's difficult to write like this. My own work is like that. I have a desire to impress 
something true on the page but it slides away from under me...."

\section{Narrative as Social - Exposition} ...To learn again to speak starting with I
starting with We

\section{Marge Piercy}

Muireann is fully aware of the importance of a "safe" classroom environment that can facilitate students' selfdisclosure. This realization has come about through her own, brief experience as a student of Women's Studies. As a nineteen-year old, heterosexual woman she felt that the emphasis on the negative, on "male-bashing", on "what was wrong, what was wrong, what was wrong" in those early women Studies classes, created an environment not conducive to exploration and discussion of multiple views. In Introduction to Women's Studies, Muireann tries to ensure that her classroom is a supportive environment, where it is "safe to question", safe to share the personal and the different viewpoints inherent in such sharing. 


\section{An Ethic of Relation}

Eor Muireann the connection between talk and relation is clear; class discussion being built from the outset on an ethic of relation--trust. Muireann hopes that if students begin to know each other, it is more likely that they will begin to trust one another with their personal narratives. Trusting relationships are built over time, however, and Muireann is patient. At the outset of the semester some students are reluctant to share their written self-descriptions. Students sit together at close physical proximity in the classroom but they are unfamiliar with one another. By speaking, they risk rejection for "being who they really are"; many students chose to remain silent and allow individuals like Samantha, a student in architecture, Donna, a psychology student, Rose, a student in English and Education, and Angela, a student in engineering, to carry the discussion, led by Muireann.

June remembers beginning the course, hardly ever speaking. She describes her reaction to the first day of class. June, a sophmore student returning to college after a two year break, comes to class expecting to experience camaraderie--a feeling of familiarity and trust that exists between friends. Instead, June feels "intimidated" by both teacher and students; she is unwilling to participate in such an evironment. June's experience underscores the importance of good teacher-student, and student-student relationships 
in Introduction to Women's Studies. Muireann is also aware

of their importance. She encourages the students to try to get to know one another. Moreover, Muireann realizes that she must make the first step in building a trusting relationship between herself as teacher and the students.

In an attempt at building a strong student-teacher relationship Muireann is highly supportive of students contributions in class. In response to Rose's disclosure of a problematic relationship with her parents, Muireann smiles in affirmation and says, "Look at what they're missing." Eor Muireann a supportive environment also means that she does more than simply accept and affirm students' narratives. Muireann also offers explanations to help students understand their particular problem or concern from another perspective. She explains to Rose: "There are composite pieces to us, different sides that we show at different times when we think it is appropriate." Muireann tries to help Rose see that she is not being "fake" with her parents; it's just that we are complex human beings with many sides to us. Here Muireann supports Rose, but also attempts to extend the meaning and significance of Rose's initial interpretation of the relationship with her parents. Muireann is not finished; she challenges Rose to think even further, to go beyond her sense of self in one specific relationship to explore her self-definition more broadly. Muireann asks, "Is there a 
place inside you where you are cleansed from what other people think of you?"

Students begin to explore this question but not alone. Muireann is right there with them, describing her own struggle with inscribing a sense of herself in her writing: "It's difficult.... I have a desire to impress something true on the page...but it slides away from under me." Muireann does not present the answers to her questions but shares her own dilemmas in an empathetic manner. (Interesting and important questions do not have instant answers, perhaps). By means of supportive affirmation, explanation, challenge and empathy from Muireann, students begin to "feel safe" in the teacher-student relationship and begin to "open up" more and more as the semester progresses. Sue notes the progression of the relationship and concomitant feeling of comfort in the class.

And so into the class people have gotten more open, I mean... I see a lot of people who are talking more and seem more comfortable.

June finds that she feels "comfortable by the end of the semester". The "comfort" that students allude to describes, I suggest, a classroom environment that is "low-risk" in relational terms and facilitates the taking of risk in terms of self-disclosure. 


\section{Students' Perceptions of Relationships}

Muireann's attempts to build a trusting relationship between herself and her students is interpreted in interesting terms by the students themselves. Some begin to see Muireann as a potential friend; others view her as a "co-learner"; still others understand her questions as a supportive challenge to their thinking.

Students speaking about their relationship to Muireann begin to see the potential of friendship between themselves and the teacher. Naomi, an engineering student from Kentucky, for example, thinks that Muireann would be a good person to "sit and chill with!"

$$
\begin{aligned}
& \text {...she's the kind of teacher I'd like to go } \\
& \text { sit and chill with and talk about not women's } \\
& \text { studies in particular but other issues } \\
& \text { because she is someone who has a point of } \\
& \text { view about everything... and she would think } \\
& \text { about it before she says it... }
\end{aligned}
$$

In fact, Naomi tells me that she had planned to ask Muireann and her class mates over to her apartment "to watch a movie together...so it'd be fun". It is apparent that Naomi views Muireann as a "person" behind the "teacher".

Sue talks about other teachers that she's had in college and contrasts her relationship with them to her current relationship with Muireann.

$$
\begin{aligned}
& \text {....If you saw them on the street, you } \\
& \text { wouldn't say, "Hi" to them because you } \\
& \text { wouldn't expect them to even acknowledge } \\
& \text { you... . like they always put themselves higher } \\
& \text { than you. And with Muireann . you feel. like } \\
& \text { you could talk...not only say "Hi", but stop }
\end{aligned}
$$


and talk to her about the way your life is going... so you really have a friend.

Sue is unlearning an old school script that presents the teacher as an authority. Muireann, she feels, is her friend, and this encourages her to speak up in class, to tell her story. Sue says, finally, "So at least it makes me speak...that's really a strong point. I've never had a teacher who did that before..." There seems to be a correlation between the redefinition of the traditional concept of "teacher authority" and student voice, in Sue's case.

An intentional relinguishing of an endowed authority, on Muireann's part, is perhaps what leads students to begin to redefine "authority" as they have known it. Students begin to see Muireann as learning just like themselves. One day, for example, Muireann engages the students in a brainstorming activity. As she steps onto the platform to get to the blackboard she says,

\footnotetext{
Even though I am up here this does not mean that I have the truth or that I know anything. [The students respond with laughter.]
}

Donna is impressed with Muireann's non-authoritarian approach in the classroom, in terms of teacher-knowledge.

I like how she's so aware, where she doesn't take the subordinate-superordinate attitude like I'm going to stand up here on this podium and you all sit there and listen to me talk. She's aware. You know, "We'll just all sit here together and we're all equal and you have your opinions and I have mine". 
Donna interprets classroom discourse as an exchange of "opinions". This is perhaps why she finds it easier to accept the teacher as an equal in conversation. "Talk" constitutes individual views rather than structured knowledge that she is used to receiving in her other university courses.

June appreciates Muireann's willingness to share her unanswered questions and be "very honest about the fact that these are all things that she's learning too." June admires Muireann greatly and her admiration is surprising to herself! "It's interesting," June relates, "because she's probably the first instructor that I thought didn't already know everything."

Many of the students see Muireann as being highly receptive of their contributions in class. However, rather than seeing her as "blind" acceptor and affirmer of their stories, students appear to be challenged by her particular "brand" of receptivity.

I think when you say something she hears it, she listens to it and if she says something back it's not going to be: Yes, that's right. or you know, it's going to be something that she picks up on and something that she thinks you need to think about.

June feels challenged, challenged to think in other patterns, challenged to participate in her process of selfunderstanding.

It's good too because if you have a different opinion she's not going to sit there and let 
you have the opinion she's going to say... why...look at it from my point of view.... And so you can come to see where she's coming from and so it's not bad.

Donna also appreciates Muireann's process of questioning students to further their understanding by coming to issues from different perspectives.

It is important to sue that her contributions in class are not ignored or ridiculed no matter how "stupid". Muireann accepts students ideas, links them to the ongoing discussion and then uses them to challenge students further. Sue explains how Muireann links students' ideas to one another and then, to the main theme under discussion, no matter how tangential the ideas might be.

...And she doesn't make you feel stupid.... I think a lot of times people say things that are kind of stupid.... I mean including me, and she doesn't say, "No. Yes". All of a sudden she says something that will tie it all together..so it makes you feel less stupid.

According to Sue, Muireann values each individual's ideas. Rather than dismiss the irrelevant, or unimportant, Muireann weaves all contributions into the fabric of the classroom discussion. Rose's comment on her relationship to her parents is woven into the discussion, to be used by Muireann as an opportunity for self-understanding of students.

Despite a general feeling of comfort with their relationship with Muireann, students experience a certain confusion. The confusion surrounds the role of Muireann as 
their evaluator which seems to conflict, for them, with her supportive role. Initially, June finds it difficult to think of Muireann as other than "the professor who teaches me and grades what I do". As the course progresses, however, June learns to trust Muireann and share her personal experience with her, only to realize that she is in fact being graded by Muireann. Upon this realization, June begins to find it difficult to express her personal experience, particularly when it involves her journal writing.
You know I was just writing them and I needed to write things that would please her, you know, and it was hard to get in touch with how I was feeling and thinking because it was a performance....

June's efforts to get in touch with her thoughts and feelings are thwarted by the knowledge that she will be graded by the teacher. Hence, June feels that she must figure out and do what the teacher requires in order to "make the grade". June's efforts, however, are not the only ones thwarted by evaluation schemes. Muireann is frustrated with having to grade students' journal writing. In her words,

I think a lot of people are dealing with a lot of different things and trying to figure them out. ...they are really asking questions and I was frustrated again because I was thinking I've got to judge their process of self-discovery and I don't want to do that....

Students' process of self-understanding may be endangered by evaluation practices. Ironically, the danger may be greater in this particular classroom. Students begin to suspect that 
in order to "do well" they must agree with the teacher's opinions. Sue expresses the concern that a lot of students "weren't satisfied because Muireann graded hard". Students, Sue explains, are left wondering, "what does she want from me?" Donna suggests that perhaps Muireann wants a reiteration of her-the teacher's-views.

But one thing that somebody told me was that... the papers you would write had a lot of your own opinions in it and if it wasn't her opinion she was a little more.. I think she was a litte tougher on it...

The role of Muireann as an evaluator creates a potentially high-risk context for students' processes of self-disclosure toward self-understanding. Muireann finds that the student-teacher relationship is something that has to be continuously "worked on", so as to prevent heightening students' feelings of vulnerability. Muireann meets with June in her office to discuss how journals will be graded; her task is to reassure her student and rebuild trust between them. Muireann explains to June that she would be grading journals according to the level of engagement, not according to particular perspectives on the issues. June comes out of the office thinking, "I don't know why but I trust her."

There are certain threats posed by students to one another when personal experiences are shared in a classroom context; the teacher-student relationship is not the only one to be considered. In Introduction to Women's Studies students seem highly aware of one another. 
Donna seems happy with her classmates telling me that she thinks that it's a good class.

I mean there are really good people in there.

I mean they are real easy to talk to and when you say something you don't feel like, "Good everyone thinks I'm stupid", you know...you feel comfortable...

However, as with all relationships time is of essence. Naomi, a major participant in class discussion, is very silent at the outset of the course. She explains that she spent a good deal of her time, initially, "sumning up" individuals. She remained "closed-mouthed", to use her term, until she thought she had figured other students out. Once she "figures out" the other students Naomi enters into discussion, enjoying the exchange of views.

I like to hear someone say something I don't agree with and try to justify why I don't agree or why I should agree...

Nevertheless, Donna and Naomi are frustrated with her peers whom they feel "really have a lot of things to say but they just never say it." The frustration with silent students, whose stories never get told within the classroom, takes a number of forms. Naomi dismisses such students as "so backward, just like that girl we read about in Maxine Hong Kingston about the girl who wouldn't talk--she just wanted to be on her own." Naomi apparently feels that such "wanting to be one one's own" is unacceptable to the larger group. Many of these silent students only speak when "they're with their little group of girls", she comments (in 
a somewhat derogatory tone) so she doesn't "really like that kind of people".

Students' frustration with those they perceive as non-participatory may reflect an unease with the process--a process in which they publicize their stories and subsequently, feel violated by the silence of the other students. Students cannot decide whether the silence of their peers is receptive or critical. They interpret the silence of many students as "non-relational", constituting a lack of trust.

Ironically, June, being one of the more silent students, sees her responsibility to her peers more in terms of listening.

...listening to the way they... what they feel about a certain issue, how it compares to what you feel....

June's connection to the group seems to grow through her listening process, "I guess there are always a few people that you feel more connected to because they've said something...that you think...yeah, I feel that way, too". June defines her silence in terms of her connection to other students. Students who differ from her don't seem to pose a threat to her, but she is more inclined to feel closer to, and trusting, of those students that hold similar views to her own. 
By the end of the semester Muireann is satisfied that trusting relationships have grown among the students and herself.

I think they're hearing each other and I think that might be the most valuable thing of all. I think they're hearing themselves and I think that they are hearing each other. I think they trust me....

During one class discussion on "motherhood", Muireann finds herself left behind as the students challenge one another, question, affirm and oppose. "When this happens I feel that I have been successful", she says. The students narrate their own stories, starting with "I" but in the context of "We".

Adrienne Rich (1979) writes that "the possibilities that exist between two people or among a group of people, are a kind of alchemy. They are the most interesting thing in Iife." Rich (1979) goes on to describe those possibilities as frightening but not destructive, as those scicial encounters extend the possibilities of "truth" between people. Maxine Greene (1988) believes that telling one another stories, narrative thinking, "releases imagination or the capacity to summon up alternative possibilities". In telling the stories of our experience to one another we engage in terms of who we are; we break through the "shells of privatism, the chill structures of autonomy", we reach out to bring something common into being. Hannah Arendt (1985) calls this commonality an "in-between" space,... and all the 
while we are building a sense of ourselves. The in-between begins with people speaking and acting to one another, Greene (1988) writes. The in-between is a process. There is no end product; it is intangible...

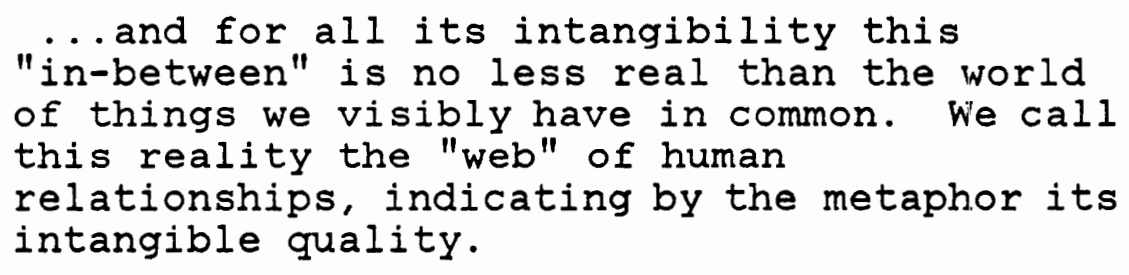

(Greene, 1988)

In Introduction to Women's Studies, Muireann attempts to create an "in-between". As she does so we may well inquire as to possibilities that come about. To this question I will now turn.

\section{Narratives of Experience as Performances of Meaning - vignette}

What is Adrienne Rich's major point in the essay, "Compulsory Heterosexuality?", asks Muireann, as she takes a quick glance around the circle of students staring in her direction. Silence. There is a long pause, giving Muireann time to be reminded of Marian's visit to her office a few days previously.

Marian is a tall young woman, a senior in engineering, with a 3.9 grade point average. She is taking Introduction to Women's Studies and participates in class discussions with a certain vigor and passion. She is emphatic in her tone of 
voice, and thoughtful and insightful in her comments on literature or personal experience.

Muireann remembers Marian's offer of help.... "From some of our class discussions I have the distinct impression, Muireann, that the students are homophobic. We really need to zone in on the issues surrounding homosexuality. The language that the students in Introduction to Women's Studies use--"queer", "straight", "bent"--it's crazy in this day and age. They need to be set right on the issue. I think, Muireann, that tomorrow's class is a crucial one. If you want I can do any sort of presentation to help...."

Muireann, not knowing quite how to deal with this offer of help, speaks in a slow, explanatory tone, "Yes, this class on compulsory heterosexuality is important, Marian. I feel a little inadequate actually being a heterosexual women; I sometimes think that I am unable to address the needs of my students who are not heterosexual. But because this is an important topic we need to approach the issue carefully. You see, Marian, many of these students have preconceived notions about homosexuality which stem from religious beliefs; they hold those beliefs firmly and without question. We don't want to make them feel threatened but rather encourage them, in a friendly environment, to question their beliefs." Marian seems a little impatient at Muireann's calm and she silently contrasts it to her own passion on the subject. Marian says loudly and urgently, "But they have got to be 
made to see that homosexuality is as valid a sexual orientation as heterosexuality but that cultural ideology has made heterosexuality compulsory. "Well," answers Muireann, "that's exactly the point of Rich's essay. Don't worry about the discussion. I think it will go quite well. It should be an interesting exploration of the issues...."

"'An interesting exploration!' Now that is funny", thinks Muireann to herself. The students seem to be refusing to talk today. Maybe she was wrong and Marian was right. Muireann had tried to get the students to talk about homosexuality but to no avail. The result: a wall of silence. Maybe they need to be told as Marian had suggested. Now Muireann decides to confront the students in front of her.

"I don't know why you are so reluctant to discuss this issue. We have to explore it. I know what you're doing. You can't avoid the discussion; you can't avoid it. We're going to sit here for fifty minutes. So let's get this issue out in the open and talk. The issue isn't going to go away. Marian announces, "Yes, we've got to bring this issue out into the open and talk about it. Why is everyone so afraid to speak? Usually, people who are against homosexuality don't understand it; they don't understand it because they they have never known homosexuals as friends, real people. That in itself is amazing when you realize that ten percent of the population in the United States is homosexual. We 
need to recognize that fact. Homosexuals have the same rights as everyone else but they're treated like second-class citizens."

Donna retorts, "The fact that there are so many homosexuals in this country does not make it right. Most of us, well I was, raised to believe that homosexuality is wrong. This is a fact requiring no discussion."

"I can't believe that anyone really believes this propaganda", replies Marian. I mean I know what you're referring to in terms of established churches. I'm a member of the Catholic church myself. Rather than leave the organized church I take the attitude that if I remain a member, then I've some chance of changing things. I think changes are possible. For example, the chaplin of the university Catholic community spoke at the most recent gathering of homosexuals on campus. This is progress."

Sue raises her hand. Muireann calls on her. "Well, you know I think that there is a lot of truth in what Marian's saying. I mean, my boyfriend was raised by his lesbian aunt. She raised him just as well as anyone else would have. He's fine. Homosexuals are just ordinary people. Maybe we say what they do is sinful because we're afraid of them--they are different from us."

Rose's mouth drops on hearing Sue's story. She says, "I would be afraid that children raised like that would also be "queer". " 
Marian retorts loudly, leaning across her desk toward Rose. "Such language is really awful. I wish people wouldn't use "queer" like that. It really bothers me. It's obvious that we all buy into a certain norm of how the individual should be or must be, that is, of course heterosexual. Anything that is deviant from the norm is perverted.

Though Muireann makes an attempt to interject during the conversation, she is unsuccessful in doing so. It's as if Marian has taken over an authoritarian role in the classroom; she listens carefully and is always ready to retort emphatically.

Samantha speaks from the back of the circle, "I read once about homosexual teachers in elementary schools. I was horrified. I mean I can understand why some parents would worry. There is so much child abuse these days."

Muireann attempts to question Samantha further. Marian becomes rather red in the face, shaking her head from side to side in disbelief. It is Rose who speaks. "I wouldn't mind if the teacher kept his/her sexuality out of the classroom. I mean they shouldn't announce it in front of the children." Muireann holds up her hand to silence Marian who seems ready to "explode", while she says, "We really need to listen to ourselves here...." It's no use. Marian must speak. Pointing her right hand in the direction of Samantha she shouts, "Why on earth would a homosexual be: more or less 
likely to abuse a child? It's ridiculous! In Scandinavian countries gay and lesbian teachers are acceptable, as are homosexual parents. In the United States we have such a narrow view of "parenthood". We need to redefine it." Marian stops to catch her breath. She is just about to continue when Muireann captures the moment.

"Let's get back to Rich's concept of the lesbian continuum. Women loving women, be it a platonic or a sexual relationship. I'd like to hear your views on this." There is silence as Muireann awaits a reply.

"Well," says Marian, recapturing the moment, "I wasn't finished you know." Everyone laughs, including Marian and the tension is diffused momentarily. As Marian continues, a ripple of agitation flows through the room. The looks on students' faces tell that they have heard quite enough. However, Marian says what she intended to say. "Anyhow, all I wanted to say, was that we're still operating in stereotypes--homosexuals are perverts, deviants, child-abusers. We need to reconsider our stereotypes carefully." "Marian." It is Muireann who softly calls out her name. Marian, unheedingly, continues. "It's just like the warped perception some individuals have of "feminists". The sadness is that we operate on the basis of those stereotypes and it's discriminatory."

Donna, silent for most of the discussion, speaks up now, "Perhaps what you're saying is true but...." Marian 
interrupts, "What I'm saying is..." Donna interrupts, "Look, I let you speak. Now it's your turn to listen to me. I'm Baptist...."

Narratives of Experience as Performances of Meaning Exposition

The narrative mode leads to "conclusion" not about certainties in an aboriginal world, but about the varying perspectives that can be construed to make experiences comprehensible.

Jerome Bruner (1986)

Students in Introduction to Women's Studies engage in a process of self-understanding in part by examining their differences from each other, in terms of perception and interpretation of experience. Muireann sees the political significance of difference in that students learn of the existence of multiple interpretations for a single event or experience. When students are confronted with difference Muireann hopes that they will listen and learn "to respect varying points of view".

I suppose it's [sharing narratives of experiencel a political act in the sense that I try to teach respect for varying points of view.... I try to teach them to listen....

Muireann establishes that difference among class participants does exist, and moreover, it will have to be confronted by all concerned. At the beginning of the semester Muireann explains to the students how they might approach the class process. 
Well, let's say if you read or heard something about marriage that you didn't agree with.... You must ask yourself, "Why do I think this way? Why does this make me feel this way?" Expect differences within the class; not everyone will agree with you. There will be disagreement.

Muireann suggests that confronting different viewpoints can be challenging if the students ask themselves, "Why do I think this way?". Confrontation with difference can also be empowering, she explains, as it can lead to new ways of interpreting experience: "I felt empowered when someone showed me a way of looking at or doing something...", she shares from her own college experience.

\section{A "Difference-Response"}

Though Muireann establishes the importance of difference among class participants, the students themselves express a variety of responses. Some students attest to liking the different views expressed in classmates' stories. Naomi enjoys the variety of perspectives offered by students in the class, given, for example, their rural, urban, ethnic backgrounds, she explains. Naomi praises Muireann's efforts to facilitate and incorporate different viewpoints.

I like being around different people... and in the class...so you're getting all different kinds.... It was nice and I think Muireann helped that a lot....

other students came to Introduction to Women's Studies expecting a certain perspective, that is, a feminist 
perspective. Sue expresses frustration at having to listen to non-feminist views of many students. Because it is "really hard to see people react to certain things" the way they do. Sue decides to dismiss those views out of hand.

I feel that people who aren't feminist... Who are really right wing... are that way because they are too dumb to be otherwise or they are too selfish...either that or they're very uneducated....

In Introduction to Women's Studies, there is a third reaction to the array of different perspectives presented in class. This reaction reflects the difficulty that some students have in handling difference when they feel threatened by it. A case in point is a particular class discussion on homosexuality.

Muireann assigns a theoretical essay by Adrienne Rich called, "Compulsory Heterosexuality", for reading. Interestingly, this is one of the few pieces of non- literary genre that are read in Introduction to Women's Studies. After a student, Marian, visits her in her office, Muireann is a little apprehensive and wonders how the class will progress. At first the class doesn't seem to be progressing! There is no overt response to Muireann's inquiry regarding student response to the article. Then Marian begins her defense of homosexuality as a valid sexual preference. Marian is vociferous on her point. There is almost a silent consent among the other students that Marian is "different" from them; her separate stance prompts other students to feel 
their "sameness", their affiliation with one another, and thus affirm their majority position as contradictory to Marian's. The teacher is silent also though she struggles with Marian for "air time". Marian is speaking from her experience, though she never shares this openly with the class.

When the interactions increase between Marian and the students, the discussion takes on highly emotional tones, without ever becoming explicitly personal. Both Marian and the other students become increasingly entrenched in their respective positions and unwilling to listen, let alone accept, a different point of view. Other students in return become "louder" and fail to connect or enter into Marian's view on homosexuality. Muireann struggles to enter the discussion and finds her task as impartial referee, assuring equal air-time to all, an extremely difficult one.

Afterwards the students response to this particular class indicates a very real discomfort with the classroom process. Naomi senses that students are "blaming" Muireann for facilitating the discussion in the first place and later, for allowing it to continue.

I think that there are some that have respect for her and some have a lot of disrespect for her and the fact that she lets us say some things and they don't agree and they kind of take it out on her...like when they were arguing about lesbian relationships that one day. I felt like a couple of them were looking at Muireann as if it was her fault 
that all this was going on...because she was allowing it to be discussed and all that....

The language used here, "she let's us say" or "it was her fault" is interesting. Students view Muireann as the authority who "allows" and "permits" certain issues to be raised for discussion and, therefore, is at "fault" in all this; she is very much an authority figure to them, despite her efforts to the contrary. Naomi, herself, suggests that issues like homosexuality should be discussed in ways that detaches or distances participants from them.

Well, I thought a couple of girls really got hot about it. The one girl that really defended it...so many people in that class were like, "I know she's gay because she was saying all that", you know.... I thought there would have been a better way for her to state what she was saying and not make the girls think that. It's just the way she came across.

Getting "hot" about an issue is unacceptable, according to Naomi, especially so because others are going to come to certain conclusions. In Marian's case some students conclude that she is a lesbian, although she has never stated so explicitly in the classroom. Naomi seems to believe that one's homosexuality, even when implied and not expressed directly in discussion, should be kept secret or hidden. Here, she may be silencing one distinct kind of experience. Sue's response is similar. Sue is disturbed by Marian's openness about homosexuality. She is embarrassed for her. For Sue the subject is too close to Marian's experience and 
therefore is "taboo" in the public forum of classroom discussion.

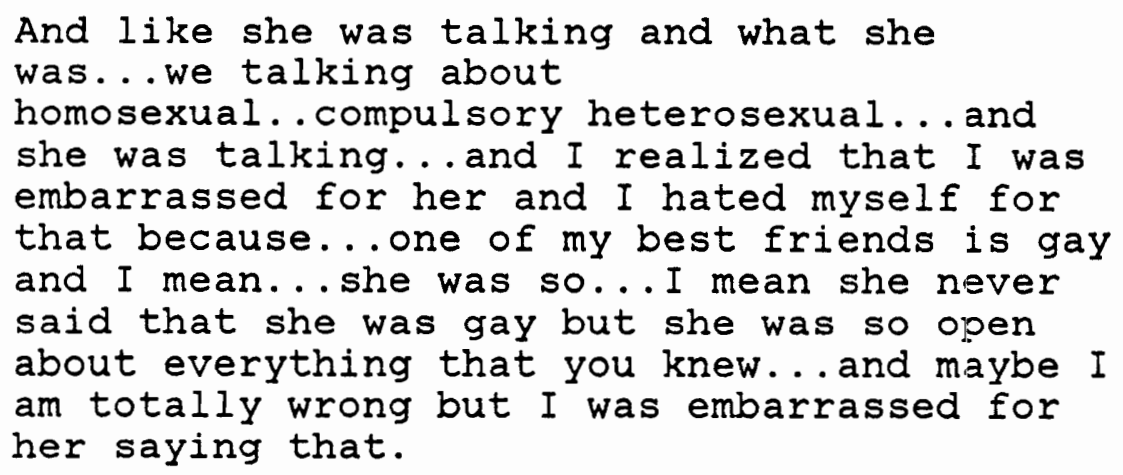

To be openly passionate on an issue implies, for Sue, that one is intimately involved with the issue. She concludes, therefore, that Marian is a lesbian. Sue goes on to describe Marian as "oppressive" and we are left wondering if, in fact, it is Marian's difference, in terms of life choice and perspective, and her insistence on making her views heard, that is oppressive to sue.

Rich warns us that when we begin to share personal experiences we have to be careful not to "gaslight" and silence each other. This may be close to what's happening in Introduction to Women's Studies. Speakers risk getting less than responsive reactions from their listeners, who would prefer if they didn't speak so "irrationally". Marian speaks emotionally in class. She is "in" her experience of homosexuality, hers is this "instance of suffering". Do students render Marian's experience, and Marian herself, as "other" than themselves, threatening their ways of being, their standpoints? We still have a lot to learn about the 
social dynamics of sharing experiences of oppression, the piece of the oppressor that we carry around in each one of us...that makes us want to silence the "other".

\section{Teacher vs. Students: The Irony of Difference}

Marian's struggle to be understood during class discussion emphasizes deep-seated differences between class participants. Her struggle is indicative of many similar ones that Muireann herself experiences as she presents and represents views different from those of her students.

On one occasion a conflict arises between students and teacher; it arises almost incidentally around the topic of the ongoing state elections. Though the discussion occurs tangentially to the planned agenda for the class it is important in that it reflects Muireann's willingness to be flexible regarding the syllabus, and her earnestness in connecting "life" to "school" for students. Above all, the incident that follows reflects the irony of difference in Muireann's classroom. Muireann encourages displays of differences; however, there are some differences between students' views and her own, that she would wish to eliminate. Below Muireann calls out for "sameness"!

The following exchange takes place the day after the state elections in November. Muireann opens class discussion by sharing her feelings of frustration over the election, "I'm really frustrated...the election... I stayed up all 
night. There is to be a recount in three weeks. How many of you vote? [Three hands go up, approximately twenty students are present] Why not? Angela: If I voted it wouldn't make any difference anyway.... Muireann: You guys, I know when I was in college and an absentee vote I didn't either...but it's important to exercise your vote. When you don't do it you're exercising a kind of willful powerlessness. Voting in this state had ramifications elsewhere. Even if it means picking the least worst.... Rose: It's too much of a hassle. I can never get them straight...to me right now it's just not that important. Muireann: You mean it's not important?! Rose: I'm being honest. I know it's not good...but I have so many worries and pressures...it's just too much to figure out. Naomi: I feel the same. Rose: I didn't like any of the candidates Muireann: Is there ever an ideal candidate? Tina: It's so difficult to understand it all Muireann: There's a summary in the paper...... The discussion continues and concludes with a comment from Muireann: Fall from innocence... the beginning of self-awareness. You sometimes have to compromise your beliefs so as to be effectual. There may not be an ideal world achieved but that doesn't mean that we don't do anything.

Muireann struggles with the seeming apathy of her students to whom voting is a "hassle". In urging students to exercise thair democratic right Muireann invokes students 
to her way of thinking. On reflection Muireann explains that it is times like these when she feels the need to "split herself", as she described it, and remember when her perspective, or view of the world, was similar to her students' whose views now frustrate her. She shares, .. It is so important to me as a teacher to take myself back to not knowing it...myself... shared process...split myself...

A splitting of self, or what one might classify as a "pedagogical schizophrenia", may be had by students and teacher also as they recognise and acknowledge the ambiquity and the contradiction between their different frames of reference.

When students and teacher enter the classroom of Introduction to Women's Studies, they take with them a view of the world, a world-picture or "weltbild". Wittgenstein likens the worldview to a myth, a kind of story, an inherited background of instincts, beliefs and habits against which we distinquish true and false statements (Garrison, 1987). Worldviews are acquired through observation and instruction, that is, at the level of experience, prelogical, prelanguage. When pedagogy is translated into narrative, students and teacher interact with their worldviews at the level of language and perhaps for the first time become consciously "aware" of them. June's reaction speaks to this notion, I feel, "Things I found myself saying, gosh, do I think that, 
why do I think that?" Not only are class participants confronted with their own world-pictures, but those of others also; they participate in a knowledge gathering activity in the context of experience.

Narrative in the Context of Political Discourse Vignette

Muireann checks her mailbox and finds therein notification of the up and coming English department faculty meeting; the topic: English curriculum. Well, she has two days to prepare her presentation on the value of the introductory course called "Writing and Gender".

Time passes. It's four $\circ^{\prime}$ clock and Muireann and her husband, also a member of the English Department, make their way through the halls toward the conference room where the meeting is to be held. Suddenly, a figure emerges from an office and turns to lock the door. It is the Department Chair. He catches sight of Muireann and her partner; he stands outside his office door and waits for them, smiling.

"How are you feeling now?", the Department Chair addresses Muireann. "I'm getting back on my feet, thank you", she replies briefly but politely. The three professors stand in the hall now waiting, expectantly. "We can accommodate your iliness...", the Department Chair continues. Muireann wonders indignantly to herself how HE accommodated 
to her illness, after all HE didn't teach any of her classes. However, she replies, "It is often enriching for students to have a variety of teachers. I think that they appreciate that." The head of the department continues, "But, you know, students are like a family. One teacher with one class." There is silence for a moment which feels like eternity to Muireann. "In fact", the head tells them, "a student came to me today who was deeply concerned about his professor being a Marxist". "I think it's good for students to see this", Muireann encourages. "Well, professors have to be careful with their points of view in required courses; they're not elective courses", he cautions. "Well, I'm a feminist", says Muireann, "and that's the way that all my classes are.... "I don't see why we have to be more careful with our points of view than traditional professors have to be with theirs", she adds quietly but firmly. The conversation ends and all three begin to walk in the direction of the faculty meeting room, in an uncomfortable silence.

On entering the conference room Muireann takes a position at the table with her husband. The Department Chair takes himself elsewhere. After some introductory comments, he invites discussion on the "Writing and Gender" course. One member of faculty reports that many students, to whom she has spoken about the course, believe that, "It's just a course where someone gets up and stands on a feminist platform...". 
Muireann, rather concerned with this response clarifies, "It's dangerous when anyone uses the classroom as a platform for their political views.... I don't think that we should leave our politics outside because that seems really dishonest to me... So I am coming into the classroom with books I've chosen to read, the order in which I've chosen to read them, and the criticism that I've chosen to support a discussion of them... and all of those are informed by who I am and what I believe to be important, and that: is political." Another colleague comments that perhaps this kind of teaching is in fact political propaganda. Muireann retorts, "I don't think that good teaching should work like political propaganda...but the way I teach is informed by what I think is important and the students can't escape it... when they're in my classroom...."

\section{Narrative in the Context of Political Discourse - Exposition}

\footnotetext{
"Well, I'm a feminist and that's the way all my classes are..."
}

Muireann

\section{Teaching is Political?}

Muireann recognizes the political nature of all teaching, not just especially her own. Below she describes her own 
version of feminist politics which she promotes in the classroom.

...It may be a woman who loves women... love in its political, vulnerable stance.... I think in its broadest most powerful sense it's not only concerned with women's issues but issues of race and gender in the many forms in which they occur...so I see it for myself in those broader terms. I think it means being active... I don't think you can be a feminist and be passive... and sort of embrace an ideology... and sit back on your ass and not do anything.

For Muireann being active means bringing her politics into the classroom. As a feminist teacher she admits that her values inform the selection, sequencing and discussion of course content. Muireann differentiates between "platform" and "discourse". According to this teacher, the classroom is not a platform from which to promote political propaganda. However, Muireann acknowledges that her values facilitate a certain classroom discourse. Discourse can be described as a way of seeing from a particular standpoint, political or epistemological, or both. The classroom discourse is directly related to Muireann's politics--the discourse is feminist. Muireann admits that this is an unavoidable dimension of her teaching and probably what makes it a dynamic and important activity.

Discourse can act to constrain the production of other discourses--other meanings. Muireann is aware of the possibility of her feminist discourse dominating classroom exchanges, and thus constraining the production of students' 
perspectives. Her wish to prevent this occurring is reflected in a remark to the students early in the semester, "There is no party line", in reference to student responses to the course readings. Moreover, describing herself as "a gentle teacher, a soft teacher", Muireann tries to exercise forebearance; she tries to acknowledge multiple perspectives and to avoid dealing in "absolutist terms". [We have witnessed some of her efforts in this direction during class discussions on homosexuality and suffrage, in the last section.]

Muireann believes that her approach to the world, and to "feminism", is more "amorphous" than some of her feminist colleagues; thus allowing her to be less controlling of classroom discourse. There is no certainty for Muireann regarding her feminist position; in fact, she has a problem with the label "feminist".

I have a problem with it, I suppose, because I don't like defining anything too narrowly. So to say I'm a feminist seems like it's cutting...it's like shoving yourself into a particular niche so I'm not sure that it's something that I wish to do.

To call herself "feminist" is confining for Muireann, who describes herself as being in a continuous process of self-knowledge. "Niches" are limiting for her, it seems. Due to Muireann's approach to feminism, she is very reluctant, and perhaps unable, to impose one perspective, one right answer, on students. 
So I can't go in... I just can't go in and say, "This is the way it is." And sometimes I think that's a weakness. I mean I know it frustrates some of my students. They want to say, "Well, what do you want?"

Muireann feels that her uncertain sense of self, as a feminist, is transferred to the classroom as a tentativeness, an unwillingness on the teacher's part to assert the authoritarian tones to which students are accustomed from their other university classes. Muireann explains,

I do have a lot of self-doubt. I think that my self-doubt is my own internal checks and balances as well. And I think sometimes it's justified and it helps me do a better job. However tentative, Muireann's "feminism" becomes the

frame for discussion, the background of the narrative. It pervades classroom conversations. Students' experiences are shared, and explored within Muireann's feminist framework; the constituents of stories--"characters in action with intentions or goals in settings using particular means" are repositioned in relation to one another on different terms-"feminist" terms.

\section{Rape and Agqression (Viqnette)}

"From reading your journals I've learned that many of you feel that the rape victim is responsible for her own violation, because she abuses drink or drugs. I'm really concerned about this view, to be honest. So let's talk again today about rape. I'd like you to consider more on 
"aggression" and use Monday's discussion with today's in your journals. It was interesting to me that we couldn't define "aggression". What is aggression?" Muireann introduces Wednesday's Introduction to Women's Studies class.

Naomi responds to Muireann's question, "Well, I grew up in a small town in which the people were fundarnental Baptists. The idea I have because of this background is that the male is always the aggressor.

Muireann questions Naomi, "Is there anything else that reinforces this notion?"

Angela suggests, "Well, there are rules for guys regarding dating. For example, the guys always ask the women out in the first place--it's their responsibility from the beginning.

Muireann challenges the students, "How many of you call someone up to go out with?" In response fifty percent of the students' hands are raised. "Good", Muireann praises.

Muireann continues, "How many of you expect him to pay for you?" A ripple of laughter moves through the classroom. Jennifer laughs aloud and exclaims that it would be wonderful if someone paid for all her entertainment, her "good time". Muireann directs her next question at Jennifer. "What priviledges are given to the person who pays?"

Angela answers instead of Jennifer. "It's a question of ego--the male has always taken the initiator's role--he pays and gets to chose where to go perhaps. It's tradition. Now 
we've come to accept it as the man's role. Men pay and women look good."

Muireann repeats, "Men pay and women look good." She continues, "Ask yourself what traditions and values embue our actions...the guy having the money, the woman looking good."

Rose explains, "Well, if the roles are reversed the woman may be viewed as a slut."

"The man always goes after the woman. My father went after my mother because she was a challenge--other chicks were too easy", Tom contributes.

Some mouths drop in dismay at Tom's remarks; others with concern as to Muireann's response to Tom's language. The latter students are not disappointed as Muireann responds instantly, "The language of the hunt, the chase--he went after her. It is interesting to me that our language reflects the categories with which we describe our experience. In a dual system one thing has to be stronger/bigger/better than the other. Woman has become the "other" to man. Those that have been called "male" traits have been seen as big, aggressive, strong, active while "female" traits have been viewed as small, non-aggressive, passive, and weak.

If woman's way of achieving intimacy is to be passive and man's right is to pay for it...here we have active and passive roles with a lot unspoken in-between. People tell you all the time how you should fit in as a man or as a woman. 
All you have to do is look at magazines to see how these messages are communicated and notions of "male and female" are perpetuated. There are so many double messages about sex that make us feel more comfortable about things like rape, as if it's okay.

Cindy raises her hand. She begins, "I had a friend who was raped but she was drunk, really drunk and got left behind at a party. She lost all control of herself. She never reported the incident."

"Why not?", asks Muireann, as the class listens with interest.

"Well, I suppose she was out of control", answers Cindy.

"Why not?", Muireann asks again.

"Like I said, she was out of control and I suppose she felt that it was partly her fault", Cindy replies grimacing at the line of questioning.

"Why? What's the big deal with control? Haven't any of you ever enjoyed being out of control. I don't mean necessarily due to cocaine or drink. Why is she blaming herself?"

Cindy replies rather emphatically, "I don't know." Muireann retorts, "You do know. It's good. Keep asking yourself, "Why?". 


\section{Discourse Exemplified}

The theme of "aggression" and the topic of "rape" have been previously discussed in Muireann classroom.

Predominantly, students perceive aggression, in the context of rape, as somehow "deserved" by the female victim.

Muireann is concerned with this aspect of student discourse; their perspective concerns her and so she raises the issue of rape/aggression one more time in class. Muireann's actions imply that there is a more useful or valuable way of looking at the issue of rape.

The classroom discussion seems to develop in a certain direction led by the following questions:

What is the relationship between violent aggression and our liking to be passive and taken care of? In human relationships do we want our vulnerability to be taken care of?

How many of you call someone up to go out with? How many of you expect him to pay? What priviledges are given to the one who pays? Ask yourself what traditions and values imbue our actions--the guy having the money and the woman looking good?

The questions serve as a series of challenges to the students to make certain connections. The issue of course is whether they constrain the expression of students' own meanings. In this instance, the teacher draws a connection between the cultural passivity of women in relationships and acts of violent aggression against women. Hence, the questions reflect an implicit background of "one true story" of our experiences--a feminist story. 
Muireann also seizes an opportunity to use the students' own use of language to elaborate her perspective. When Tom uses the term "hunt" to describe his father's pursuit of his mother, Muireann responds The language of the hunt, the chase. It is interesting to me how our language reflects our experience. In a dual system, like we have in western culture, one thing has to be stronger/bigger/better than the other. Woman has become the "other" to man. Those that have been called "male" traits have been seen as big, aggressive, strong, active, while "female" traits have been viewed as small, non- aggressive, passive and weak. The different perspective she offers is a feminist one, which attributes rape to a patriarchal culture oppressive to women. When we explore Muireann's line of questioning, and her exposition of "dualitites", it seems clear that she is working with students to uncover the patriarchal ideology underlying the phenomenon of rape. Toward the end of this particular class on "rape", Muireann summarizes more explicitly a feminist perspective, expounding on cultural ideology of "active" male/"passive" female syndrome; thus bringing to culmination the direction of her questioning and elaboration strategies. Muireann summarizes as follows,

If women's way of achieving intimacy is to be passive and man's right is to pay for it...here we have active and passive roles with a lot unspoken in-between. People tell you all the time how you should fit in as a man or as a woman. All you have to do is look at magazines to see how these messages are 
communicated and notions of "male" and

"female" are perpetuated. There are so many double messages about sex that make us feel comfortable about things like rape, as if it's okay.

The foregoing exposition makes sense to Muireann. There is an insinuation that by reimagining and reorganizing the attributes and activities of women that we can develop another, more appealing, feminist definition. So, if women ask men out, if women get control over the economics of their lives, if women are active rather than passive, if women get to say what they want, then everything will be different. In such a society "rape" as a phenonomen may cease to exist. Muireann's discourse frames "woman" as passive victim of assault; this discourse is indicative of a feminist discourse that speaks about experience as constructed, and within the terms of dominant patriarchal discourse.

Given Muireann's acknowledgement of her specific set of values, and subsequently, her specific speaking and teaching positions within the classroom, she is quite clear also on the ways she wishes her students to deal with her discourse.

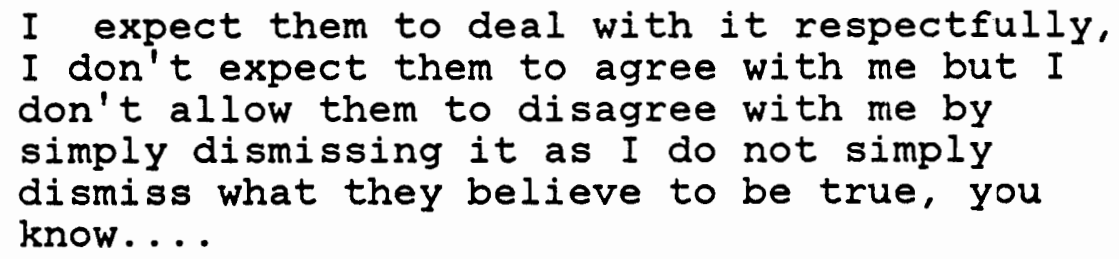

Students vary in the ways they deal with classroom discourse. Naomi says that there have been numerous times that she has disagreed with Muireann. However, this does not 
seem to pose a problem for Naomi who describes Muireann as not coming across as,

...over powerful and over bearing but she really is a powerful person... You know she is the way I think people should picture feminists.

Problems seem to arise when students feel imposed upon by Muireann's position and the discourse that she introduces into the classroom. Ironically, students react to Muireann's discourse in the same way that Muireann responds to patriarchal discourse--"it tells you how you should fit in". June describes the reactions of classmates,

I've heard other people coming out of the class... with negative opinions.. that she was trying to tell them how they should think which you know... I can see...

June suggests that the students with such notions need to approach the class differently.

So I think if you approach it with the idea that she's there to help you see what you're thinking...rather than she's there to tell you whatever's right or wrong that's going to affect how you feel about her....

Some students feel that a specific way of thinking is being imposed upon them. Yet, Sue highlights for us that discourse is not only the perogative of the teacher but something created socially and largely affected, therefore, by the students. Seemingly disappointed with the discourse of the class which turns out to be less radical than she personally would have wished.

I expected it to be a lot more feminist. I expected there to be a lot more... I 
mean...things in the class I expected the class to be a lot more radical about them like I was.... The first day I walked into the class people were like: "I don't like the word feminist"...

Sue identifies with Muireann's position: "I think she's really radical... I like that...she's definitely a feminist". However, Sue is very concerned with how feminist discourse in Introduction to Women's Studies can "offend"; she is torn between asserting feminist views and being tactful.

...they need to be told..but I tend to say things too rudely but I wonder how it would be coming from a teacher.... I think you just have to be careful in not offending people but then you have to sometimes offend people to get them to think.... I don't know I think it's important to be a feminist but I also wonder how people feel....

Sue is particularly concerned about the "grus that believe in equality and stuff" who are "terribly offended" by "talking about a lot of feminism".

Donna, like Sue, recognizes Muireann's position and she seems unintimidated by it. However, just as sue, she is concerned about the males in the classroom.

I feel bad. People like Rob...he won't speak because he is a guy. I know how some people respond to Tom, you know--"guy!"

As Donna speaks I begin to wonder if the discourse of the class as one of female experience excludes the males and posits them outside the discourse. Donna later advocates having more men in the classroom so as to facilitate more male-involvement, and perhaps, a less exclusive discourse. 
When gender is the construct central to our discourse we may be reconstituting the male-female essential difference, a mode that posits male as "other" on the one hand in their "male" experience of the world, outside the circle, unable to enter into, or challenge, the discourse of female experience. Perhaps Donna's earlier comments were getting at this point in her concern for the "guys". The "them and us" syndrome becomes particularly evident during a number of class discussions, the discussion on "rape" being one example.

The students' concerns regarding the exclusionary discourse, based on Muireann's differentiation between "male" and "female" experience, are related to her tendency to refer to "women" as a composite, unified group whose experiences are definable and alike. Muireann proclaims that "It is important to talk about these things... I feel everyone is like me... we have a common basis..." The "common basis" to which Muireann refers seems related to understandings reflected in her other statments.

Women experience difficulty in saying: I want If women's way of achieving intimacy is to be passive..

As women do we have to wait till we're dead to be heard?

By drawing attention to experiences such as "being silenced", or having to be "passive", Muireann is invoking a much needed articulation of women's experience in western 
culture. Nevertheless, I am led to ask, "What is "women's experience"? Lorraine Code (1989) writes that there is no singular female experience; the notion of women's experience is an artificial construct. Code (1989) points out that to assume otherwise would be "to mask crucial differences between and among women.

Muireann's efforts to "break silence" and to facilitate the articulation of women's life experiences in her classroom are intriquing in their complexity. The introduction of students' personal experiences, in the context of feminist discourse, within a public educational setting represent one radical teacher's attempt to move and work within the university on her own terms. 


\section{CASE 2}

\section{Introduction}

If I were to paint a picture of a wise elder, sitting outside a humble mud-hut on a straw mat, surrounded by younger and less experienced members of the tribe, all of whom sit enthralled by the knowledge of the ages being bestowed upon them, then I would be painting a portrait of Chloe, academic feminist and teacher of Feminist Theory 3000.

Before ever meeting with Chloe I had heard about her from a number of people--her students, friends of her students, her colleagues or her friends! They described her, in no less than mythical terms, as an individual with a passionate commitment to feminism, a tremendous familiarity and facility with ideas, and the authority of a university professor.

In the context of the present study, Chloe's qualities of commitment, knowledge and authority, become the bedrock of her struggle as a teacher of Women's studies. It is these qualities that distance or separate her from her students--they are less committed to feminism, less knowledgeable, and less privileged in terms of institutional authority than she. Chloe wishes to bridge the gap created by these differences in order to achieve "the best exchange possible" among participants in the course, Feminist Theory (3000). 
The differences that exist between Chloe and her students, in terms of knowledge, politics and authority, distort classroom dialogue. Dialogue can be defined as a discussion between individuals who trust one another and who share a commitment to social justice. It is a democratic form of communication in which all voices and differences become unified, both in their effort to identify and recall moments of human suffering, and in their attempts to overcome conditions that perpetuate such suffering (Ellesworth, 1989).

Chloe's transmission of knowledge to students contradicts the social nature of knowing and understanding in the context of dialogue. In Feminist Theory 3000 the unified consensual voice proves evasive as participants differ in terms of political commitment to feminism. Einally, the trust that might exist between Chloe and her students is confounded by the power differential, embedded in the teacher-student relationship.

Yet, despite problems all is not lost. If the wise elder is reflective and self-conscious of her privileged position, then perhaps she can approach dialogue within her classroom, if not fully achieve it. Chloe takes a reflective posture as she enters into an "inner conversation". The voices of the inner conversation represent Chloe's different selves as salvaged from personal and professional history--the voice of the conservative intellectual, she once was, reminds her of the privilege and authority bestowed upon her as an 
academic; the student voice which raises questions regarding the ethics of her feminist politics in the classroom and of course, finally, the feminist-voice which encourages her in her efforts of curriculum transformation in the academy. The case study that follows explores Chloe's efforts toward a dialogic classroom in Feminist Theory 3000 . First, I will try to open a window on the lively landscape of Chloe's classroom by presenting a vignette. Then I will move on to explore the origin of Chloe's "voices" in the context of her personal and professional history. I then attempt to represent an "inner conversation" that Chloe might have had, by constructing a discussion among Chloe's "voices" on the topic of dialogue in Feminist Theory 3000. I constructed the "inner conversation" from Chloe's own reflections on classroom process offered in interview and during classroom discussions. [My analysis of this data showed Chloe to be highly reflexive in her ability to reflect on her own actions, postures and beliefs in classroom contexts]. The researcher expositions that follow the "inner conversation" are designed to further interpret and expand on the problems posed to dialogue by Chloe's knowledge, passionate commitment and authoritarian privilege. 


\section{Chloe's classroom - Vignette}

A desk is scraped along the gray tiled floor in Room 423, Watson Hall. Then another. Then another. The scraping intermingles with a cacophony of chatter and the sound of an old heavy glass door open and bang closed as I enter the room to take my place in the circle. No sign of a teacher. Oh, I see signs of one--a book-strewn desk and chair at the front of the room by the blackboard. There's someone trying to get students' attention; there's nearly thirty of us here today--that's good, on Thursdays the attendance pattern is a little different.

I hear a voice say something about announcements, another desk scrapes; there's a knock on the door, one student gets up and opens it noisily to allow in a latecomer. I can hear. the drones of equations beaten rhythmically on the blackboard across the hall--engineers in the vicinity. It annoys Lesley...that sound, "Can someone shut the door please?", she shouts. "No, it's far too hot in here...there are no windows to open", another voice resounds. "Well, I'm going to go over there to tell those guys to shut up!", retorts Lesley. "No need for that"--I've located the teacher! Small, rather frail in stature, in autumn shaded pants and sweater, and laced desert boots. She looks pleadingly almost at Lesley. I notice the bright eyes behind the spectacles, the animated expression. I am drawn at once to her voice--quiet but 
commanding. Someone closes the door and at last I settle down to listen to Chloe, the teacher.

Announcements, always so many, a list of Women's studies concentrators is needed; someone's friend has suffered from the comments of a anti-semitic teacher, what procedures should be followed?; the Student Government Association is sponsoring a forum on the abortion issue; South Eastern Women's Studies Association is having a conference in a nearby town; a Graduate student in the Psychology department needs subjects for her study involving assertiveness training for heterosexual single women under twenty-five. Chloe winces and many students laugh. The student-announcer reddens with embarrassment and struggles to explain the heterosexist bias of the research. The announcements continue. There are questions to enhance clarity. Suddenly, the glass door shakes and its vibrations are felt throughout the classroom. Someone's trying to get in. It's ten minutes after two. I get up from my seat and open the door. Two men in their early twenties, looking a little bedraggled, enter the room. There is a momentary silence as they come face to face with Chloe. "We thought we'd just like to sit in and listen today", they state inquiringly. Chloe smiles in agreement. Thirty one pair of eyes follow the visitors as they find their way through the discarded empty desks in the middle of the classroom to vacant seats at the back of the circle, at the back wall of the room. 
The circle...a rectangular affair really. A circumference of junior and senior students, female, white and apparently middle-class, less make-up, hair-dye, Reebock than the Introduction class. I sit next to another foreigner, Sendyiha from India, who sits diagonally facing Joan, the only African-American woman in the class. Three or four young men sit at the back of the room--all anglo-americans who for the most part sit quietly without speaking. Close by, three faculty auditors seem to huddle together. I know that they're auditing because Chloe said so early on when she introduced them--Alexandra, a member of faculty from the English department and a creative writer; Niamh with the pearls, pearls and tennis shoes, is a professional adviser in Arts and Sciences; and Pauline, the Co-ordinator of the Women's Studies Program. Miriam is sitting in on the course also, though she doesn't sit with faculty but finds her space with the other students in the "circle". She is a Ph.D. student--ABD--from the History department at the University of Keyes, and in the area for the semester. Alexandra and Niamh sit in a row of desks just inside the circumference of the circle, accompanied by some five or six students. Lesley once suggested that we all try to fit into the circle-proper...but there never seems to be enough room for everyone.

It seems that we're ready to begin. Chloe hesitates, "oh,... I know... yeah..actually I do have one announcement and 
then I will get into Catherine MacKinnon. I think I mentioned to you all that on March 28th, Helen Caldicott is coming to this university... in fact I do remember telling you that she is the most charismatic speaker I have ever heard in my life." She continues on describing Caldicott's credentials and origins. "Well, at any rate...we have a series that's supporting the speaker--"Women Speakers and Writers"--in fact I'm very happy to be one of the women who founded that series... and I ran it for two years. We are having a meeting at four 'o clock and if anyone would like to help with the last minute arrangements please come...."

Just as I think that announcements will take up all our class time, the hour is saved--Chloe announces, "I'd better get on with Catherine Mackinnon... I have a feeling that we'll take up all the class." Chloe then takes a quick glance around the room mumbling hurriedly, and hopefully, "Has anyone else...no?...good!" Chloe seems relieved now that the announcements are finally over! Silence pervades the room. There is a sense of waiting, waiting for Chloe to begin. Most students stare in the teacher's direction waiting. She doesn't disappoint them. Chloe says rather apologetically, "Can you all bear listening to me... I promise for fifteen minutes... I swear about this! This is a very important article...it really is.... How many of you read it? Don't lie. I'm not quizzing you " There is little overt response from the students, only silent stares. Chloe continues, "Put 
your hands up, come on. Alright, how many of you at least tried to get into it?" A student voice pipes up from somewhere in the circle, "Which article?" I can sense the stifled laughter waiting to overflow. Chloe shows no emotion but answers briefly and directly, "The one for today...Catherine MacKinnon." The student, apparently unperturbed, replies, "I get confused". Still silence. Now Chloe reacts smiling, "Weak excuse". The tension drains with the laughter and there is an air of relief all round. But Chloe has a point to make. "Tell me really, how many? I just want to know." Eive of us raise our hands. "Okay," she says, "I won't comment on this." But the didactic tone is clear, "I expect to hear you write about this in your journals... and not just what I say today..." She smiles and laughs at this final remark, and so do I. "You know I don't give quizzes in this class...really...so let's do it."

Chloe gets up and walks to the blackboard behind her. "Feminism, Marxism, and the State...a big, big issue in the feminist movement... and it seems to be talked about more and more. Should the study of women be approached in terms of their sexual identification, as if the whole world is supposed to be divided into women and men, and women all cohere because they're in this sex defined as woman...gender defined as woman...or is it more important to consider people in terms of class. I'm simplifying a very complex article. "I have no problem hearing her--her tone is resonant, her 
voice projected. It seems that the class is to be lectured to but in conversational tones. My attention is held, I am enthralled. I am beginning to understand her being a school-debater. Maybe she's right... she should have gone into Law. No doubt the passion in her voice, that sense of urgency, and the importance of relating these ideas would hold any audience.

Chloe goes on to explain the syllogism of Marxism and Eeminism on the blackboard. "Marxism is to Feminism as work is to sexuality. After we've talked in here on rationality and logic, here I am putting a syllogism on the blackboard." She carries on explaining the major tenets of Marxism. The only labor that counts is the official labor..."

Rhoda, listening intently as usual, interrupts, "I thought they talked about the fact that women having children constituted economic value." I am not surprised at Rhoda's contribution. She always has a lot of interesting things to say; I wonder if she intimidates some of the other students with her knowledge on censorship, Marxism, the Bible...especially the Bible. "I'm Jewish", she announced the very first day in class and I'm always having discussions with my Dad on feminism and other issues." "Why not with your mother?", Chloe asked at the time. "Oh, she's lived feminism all her life, as a Jewish woman in medical school, she feels like she's done her share and isn't willing to talk about it 
any more." Since then Rhoda has told almost as many stories as Chloe.

"Yes", agrees Chloe, then, but Rhoda isn't Einished. "So in that respect they do put some sort of value on it but it still wasn't "work"."

Chloe immediately picks up on Rhoda's point, "Exactly! It wasn't the same thing, as you point out, as real labor". Chloe walks back toward her chair and sits down. She continues to explicate the text, her eyes moving about the room capturing students' attention, "Women's labor is use-oriented...it does not tend to produce a product...it's a continual flow of labor for which there is not economic pay...."

Now it's Joyce's turn. A Women's studies concentrator and senior in history. Joyce suggests that "a lot of third world women work continually"; Chloe affirms, "they work continually, from dusk to night...not... I mean till dawn...not dusk...dawn", she laughs. Joyce goes on, "... and most of their work...." Chloe interjects, "It's really just amazing". Joyce finishes, "Women's labor is not counted in gross national product." "It's not counted", Chloe affirms again.

Chloe continues, "Cathy Ferguson has written a brilliant book called, The Eeminist Case against Bureaucracy. I mean if women would just check the category of "unpaid labor" because no matter who you are as a woman, chances are that 
you engage in unpaid labor. You may get paid but I guarantee that you're the one who goes home and does the unpaid labor. Really, I hope that there's no one here that would argue with that point. And if every woman checked the category of "unpaid labor" on the 1990 census, they would totally mess up the entire economic system. I'm going to do jt!" Laughter is heard as Chloe makes this statement.

Now a discussion begins. Pauline, Alexandra and Althea discuss the labor involved in the act of getting up in the morning, enforced, in their view, by the dominant culture. They talk of the time taken for make-up, sprays, and so forth. Chloe laughs and comments that her morning preparations take only five minutes. Chloe draws our attention back to Mackinnon after this brief and humorous diversion, with, "...but anyway...work". Everyone laughs as Chloe tries to continue with the reading for the day, "On page...check back to Mackinnon. She wants to know if these two potent theories of power can speak to each other... and why is it that they haven't spoken to each other.... The key here is method... Bear with me, I won't stay on this much longer, but I do want you to understand it because it's a very, very important thing in the feminist program."

Chloe continues for some more minutes, discussing how feminism as a theory emerges from those whose interests it serves, until Althea, an African-American woman, visiting in the class today, interrupts. "Then how would you address the 
problem of feminist theory coming from white, middle-class women?", Althea asks. Chloe admits that Althea is absolutely correct. Teresa intervenes, "I just wanted to say that I agree with that...feminism needs to come more from a dialogue between people. Basically, what has to happen is that we have to talk, and we have to respect the basis on which people live, and not make assumptions about the way people live, according to anyone's race or class. This is what consciousness raising is for." Chloe replies, "It's a hard thing to do".

Margaret, a vocal self-described feminist and avid reader, questions Chloe, "I have a question. What is materialist feminist?" Chloe explains, and Marie adds, "It's interesting...I feel like I'm being bombarded by definitions...different kinds of feminisms. Third World Feminism, I feel, is more community based. There's a certain power that comes from that. Our approach here is very individualistic. I've come to question that a lot". There follows a brief pause until Joyce suggests, "Well, we're trained to do it." Chloe adds softly, "We're all in ideology". Althea attempts to clarify a point she made previously, "The black middle-class are as guilty as the white middle-class for ignoring the problems of the lower class.. and..." "And we think apartheid is restricted to South Africa", Chloe exclaims. Joyce informs, "It's our representation of it." 
Lesley is squirming visibly in her seat, a good example of a balance between emotion and brilliance, as Chloe describes her. I have a distinct feeling that the discussion is about to be taken in a different direction by the unorthodox Lesley. Will Chloe go with it? I suspect so. "Well, everything's a representation... Why do we have to get into all this theory? Why not just tell our own stories of labour and economies in our own lives?", says lesley.

Julie's lips seem to be twitching. Eventually she says, "Well, I'll say something.... I was just talking to a woman the other day about how when I get into Women's studies classes we read all this theory but we never talk about it as much as we talk about our own personal stories. Is it because we disrespect our ability to cope with the theory?" Amber and Jane hurry to agree with Julie. There is too much of the personal they argue, and classes can become like "self-help" groups. Margaret disagrees emphatically, stating that the whole point is to make the theory relevant, unlike her experience with psychological theory.

Amber interrupts, "but getting personal in discussions just means that you're afraid to say anything in case you'll offend anyone." Don, a Caucasian male and leader of the university undergraduate association, seems annoyed. He asks, "Why is everyone so afraid of offending. Just speak your mind, for goodness sake. That's what 's wrong with this 
university, everyone's afraid of offending someone else. How are you going to learn if you don't talk."

It is clear that by now Lesley is extremely agitated if not hostile to these remarks. She sighs loudly, "WOW!" Joyce, as if coming to her defense utters, "I think that it might be out of respect for each other." Now Lesley speaks: "Could I say something please?" She addresses her comments directly at Don, "I'm a lesbian okay? And if I am open I might get beaten up. I might get killed. I'm afraid. I'm afraid. When a woman speaks she's not sure how someone else will react. We get beaten up and hurt. Find a place where you have been hurt and you might start understanding." There is silence as we all feel the emotion, sincerity and anger in Lesley's voice. Eventually, Don admits that he has a different perspective on things. The discussion continues, slowly at first, but picking itself up as it develops.

Chloe has been noticeably silent. Now she says, "Time is up. But just let me read you Margaret Randall's poem. The essence of feminist consciousness is going out and doing something. Take this discourse into every conversation you have. She reads urgently and emphatically:

TALK TO ME

TALK TO ME. THREE

WORDS

MOVING WITH HEAVY FEET

ACROSS THE OPEN SPACES 
A SIGNAL

OR THE BEGINNING OF A POEM

TALK TO ME. NOT MEANING

"HOW ARE THINGS GOING?" NOT MEANING

"THEY CAN'T DO THIS TO YOU"

(THEY CAN, THEY ARE)

NOT EVEN

"WHAT CAN I DO TO HELP?"

DO IT, THAT'S ALL.

PLEASE

NO MORE QUESTIONS, NO MORE

KNOWLEDGEABLE STATEMENTS

THREE WORDS. BEGIN A POEM. TAKE YOUR LIFE

AND USE IT.

I hear the sounds of bags dragged up from the floor. A low chattering begins. Chloe is invisible behind a crowd of questioning students. I walk out in silence, wondering. A desk is scraped along the gray tiled floor. Then another. Then another. A heavy, glass door bangs behind me. 


\section{Finding "Voices"}

Chloe is a professor of English literature. She begins third-level education at the New University College, transferring later on to Lehrman State University, where she completes both bachelor and master degrees in English. Chloe commits herself to the intellectual life and is highly successful. Chloe's commitment and ability as a scholar are noticed by one university professor who encourages her to continue her studies toward a doctoral degree.

... a professor there who liked me very much, in English said that he had a good friend at Waterman University and urged me to apply. So I ended up in a private institution and I finished my doctorate there in 1979, and that's when I got the job here, my first and only job.

Chloe arrives at her present place of employment where she continues to be highly successful academically. Chloe attributes her success in academe to having "adapted to all the masculine models of success"

\footnotetext{
... I did my work this way: I was very aggressive. I wasn't married so I didn't have familial obligations. I made myself into the typical male model of the success story because it wasn't rampant success, but I had done all that you're supposed to do. I spent my first five years here publishing in mainstream, eighteenth century British literature and a little Irish, and published a book, got tenure....
}

Chloe might be described here in somewhat the same way as I described Gramsci's "conservative intellectual" in 
Chapter one--"as autonomous and independent and neutral of any dominant social group, endowed with a character of her own". Within the context of the university, Chloe becomes the intellectual who teaches, serves on committees, and participates in scholarship maintaining an a-political [or at least ostensibly a-politicall stance".

Chloe's standpoint, political and epistemological, remains "mainstream" in her area of scholarship despite frequent conversations with her friend, and colleague Lena. Lena's interests lies in feminist criticism and speculative fiction, both radical in terms of English literature and scholarship. Chloe describes Lena as having "always known" feminist criticism but admits that she herself had believed that that was Lena's work and that her own was just very different.

Ironically, it is through Chloe's competence and expertise in mainstream eighteenth century literature that leads her to Ocean University, as a visiting scholar, where she is reintroduced to feminism by means of feminist speakers--Marilyn Frye and Audre Lordre--and a plethora of feminist literature from the university's Women.'s Studies Center.

I started reading feminist criticism, I had never read it before.... I started reading and I went, "Wow! This makes sense." I was amazed that I could have been blind to i.t for such a long time.... 
Chloe begins to read feminist literary criticism; she finds it extremely valuable to her as a literary critic. She is astonished at having come thus far in her career without ever considering the contribution feminist theory might make to her work. One of the reasons to which Chloe attributes her "blindness" is that she feels she had become "an honorary man in the profession".

The voice of the conservative intellectual is now answered by a new, and different, voice--the voice of the academic feminist. An inner conversation begins for Chloe which feels to her like a crisis--she is paralyzed as it were as she moves between mainstream and radical perspectives in literary criticism. She is "taken out of old paradigms and into new ones".

I started reading all this stuff and I couldn't write literary criticism in the same way. I couldn't teach it the same way. I went through this crisis.... I'd be asked to teach British literature.... All of a sudden the misogyny was creeping up in their texts and I was indignant that we call this a great literary tradition.

Chloe, as the now tenured, "expert" in British Literature, must continue to teach within old paradigms--Swift and Shakespeare--all "deeply sexist" but still contituents of the core curriculum of the university. It is a challenge for her to operate within the old frames of the university with her new theoretical framework--feminism. 
Gradually, however, the voice of the academic feminist is no longer just a voice which reflects but also one which induces Chloe to act. Now Chloe becomes involved in a community of feminists wishing to formalize their community in the structure of a Women's Studies Program. Chloe describes herself as "moving from the theoretical to the practical".

I feel like I did it backwards. I've been doing the backstroke in feminism. ...And I sort of got pulled into Women's Studies and it was a crucial year.

Indeed it is a crucial year for Chloe as the lobbying for a Women's Studies Program is successful. She is requested by the dean to act as the interim coordinator.

In her new administrative position, Chloe is torn between the voice of the conservative intellectual and that of the academic feminist who would dispense with bureaucratic red tape in the interests of change in the university. Chloe tells her story of one committee meeting concerning the inclusion of Women's Studies under the rubric of Humanities so as to ensure it's inclusion in the university's core curriculum.

I came out of that meeting wanting to holler. I really did. There were two people at that meeting who understood what I was saying and one of them, fortunately, was the chair. I got nothing but ignorance and hostility from the rest of them.... They took every opportunity to demean me and make me look like I was someone fooling around with women's issues. 
The woman, accustomed to be treated as a respected intellectual, feels that she is now perceived by some as "someone fooling around with women's issues". Chloe is angry at the "hostility and ignorance" of many university faculty and administrators who seem to understand little about the longterm epistemological and political project of feminism in the academy [or indeed, trust it]. On the occasion of the appointment of a coordinator of the Women's Studies Program, Chloe is happy to leave her administrative position and return to her role as literary scholar and teacher.

The once self-described "single, ordinary, heterosexual woman" now describes herself as "lesbian, feminist, literary critic". But Chloe's route into feminism is "purely academic, not even just intellectual but an academic enterprise". Moreover, Chloe's "feminism" is, as she expresses it, still "entrenched in academic feminism".

Obviously for me it was an intellectual thing first, so feminism for me became feminist theory rather than feminism. So for me it was more of an intellectual enterprise rather than a political or personal thing. And I moved into the political and personal side of it so that last year for instance, I have been organizing buses to this rally in Washington or I have been involved in bringing women speakers--even that's academic. I guess my political side of it hasn't been that great, quite frankly, because I am entrenched in academic feminism. But I've come to appreciate the political side more. I've certainly come to appreciate the diversity of it in the world--race-class-gender nexus--that whole routine. I've come to it all through 
readings on it. I think I got politically

involved in it in an academic way.

Chloe is a self-described "academic" feminj.st.

The course process of Feminist Theory 3000 taught by

Chloe reflects her theoretical approach to feminism and her belief in the role of Women's Studies as a critique of the disciplines. Chloe continues to learn the negotiation

between being a feminist and being a university teacher. She describes her learning process in Eeminist Theory 3000.

I've learned some things just because I pick them up myself and also through what some students have been very open to tell me and offer criticisms.

Students who have taken a number of English and Women's Studies courses with Chloe have no difficulty approaching her with, what they consider to be, problems in Feminist Theory 3000. Chloe talks about the problem posed to the classroom learning process by auditors, an issue which is of concern to students.

Lesley, and I think Joyce maybe, and a couple of others I can't remember, mentioned to me that they felt that there was a circle for the class, but that there were also people who were inside of it in a line or maybe in the back and outside of it, and that was in a hierarchical manner as well. And I think that I should have been more attuned to that....

Lesley and Joyce approach Chloe after class in the hope of bringing the question of faculty auditors to her attention. Chloe is receptive of their comments, though there is little that she can do to address the problem. 
At other times, students have raised issues of classroom process within the classroom context. Chloe realizes that she has a problem "letting go" of the class discussion. She is made further aware of this problem by some students' comments at the beginning of a class period.

.. again some students told me this, and they were giving me hints throughout, "Chloe, why don't you let somebody else take the reading for the day and lead it [discussion].

Chloe listens carefully to students' voices as they encourage her to be reflective on the kind of classroom process she facilitates. The student-voice asks Chloe to trust students to carry on, or lead, discussion; to regard student-talk as making as valid and valuable contribution as faculty auditors and herself, the teacher.

To image Chloe's mind as in "endless debate" or "continuous conversation" is to value her many inner voices. Hence, there is equal acknowledgement for the "conservative intellectual", "the academic feminist" and the "student", reflecting a "radically democratic form of mental life" (Young-Breuhl, 1986).

The value of the idea that our mental life with others and with ourselves is conversational--that it is a constant interconnecting of all sorts of representations of our experience and also potentially an extension of our experience as we hear ourselves and others and reflexively interpret ourselves in and through novel conjunctions or conversational moments. 
The case of Chloe, academic feminist, provides rich evidence of an individual contending with multiple, and often, contradictory voices and their implicit speaking positions. During the course of Feminist Theory 3000 the "inner conversation" for Chloe surrounds her attempts at facilitating dialogue in her classroom, as she seeks to systematically "demystify the production and distribution of knowledge"--the course objective.

Dialogue is a process of deliberation and discussion between participants who exhibit trust, sharing and commitment to improving the quality of human life. It is a democratic form of communication in which all voices [students and teachers] and differences become unified, both in their effort to identify and recall moments of human suffering, and in their attempts to overcome conditions that perpetuate such suffering (Ellesworth, 1989). The facilitation of dialogue is not an easy task. Chloe struggles with the negotiation of teacher as facilitator of dialogue and her implicit institutional authority and explicit feminist politics. The "inner conversation" of Chloe that follows seeks to depict her struggle toward the end of classroom dialogue. 


\section{Approaching Dialogue: A Conversational Moment Within}

Chloe participates in a conversation within, between four voices of her own: the voice of Arthur--the conservative intellectual and a-political scholar; Adrienne, the student, the reflexive self in the classroom context; and finally, the voice of Olivia, the academic feminist. The issue for discussion--the possibilities of achieving dialogue in Eeminist Theory 3000 .

The Knowledge-Power Nexus (Dialogue)

\section{Arthur [Conservative Intellectual]:}

As a teacher in Women's studies you are controlling the acquisition of certain kinds of knowledges. Dasn it, who wrote the syllabus, who chose the texts, who's grading the journals and oral reports? The conflicts are still there...the conflicts between power and not power. You don't want to be in the power position..but you can't escape it, can you? You still buy into an ideology that says you don't want to be controlling.

\section{Olivia [Academic Feminist]:}

That power-knowledge nexus is the one that bothers me, because I think that's a problem. I can really tell them something but at the same time I don't know entirely how to 
divorce that relay of knowledge, the privilege of it, from the power position.

\section{Adrienne [student]:}

I suppose you're still developing a way of teaching. You must have to learn to deal better with letting go of the class more. You tend to be the central figure because you talk more. You know that you can keep people's attention, you shouldn't abuse that, I feel that, and again I told you this, and others were giving you hints throughout--"Chloe, why don't you let someone else take the reading for the day and lead it?

\section{Olivia [Academic Feminist]:}

I did that once after Joyce suggested it to me. I think I've got to do that more.

\section{Arthur [Conservative Intellectual]:}

You know the author's message and we're there to promote it, the students are there to get the message.

Olivia [Academic Feminist]: No, I know I tend to do that too much, explicate the text. 


\section{Adrienne [Student]:}

Yes, shouldn't it be more of a conversation with the text and each other. Sometimes you may get something completely different than anyone else because of some personal reaction, very personal reaction, that other people haven't experienced. And that's what it's about. It's not like there's one message.

\section{Arthur [Conservative Intellectual]:}

Naturally, I know a great deal. This may sound like an arrogant statement but I do feel that I know a lot of things. I have a lot of knowledge that I can impart. For example when I did Catherine MacKinnon's piece on Marxism and Feminism. I know that I've read at least ten books on any one of those issues. I can really tell them something. I have the information.

\section{Adrienne [Student]:}

You did! You talked for the most part of that lesson.

\section{Olivia [Academic Feminist]:}

How did you feel that class went?

\section{Adrienne [Student]:}

Well, part of the problem is that, we students aren't doing the reading. Remember that student who couldn't recall the 
article assigned for that day? I guess there's no incentive--no tests, no question-answer routines, no pop-quizzes. If you lecture then you solve the problem. Explain it to us, we'll understand; it's a "learned behavior" and honestly, it's an easy way out on one level for us. We come to class with the expectation that it's going to be explained anyway.

\section{Arthur [Conservative Intellectual]:}

Additionally, isn't it easier for the professor to say, "Oh forget it, and if you haven't done the reading or you don't want to talk I'll tell you what it says and I'll show you what's important cause I have something that I want to say anyway." You know, you have this certain message to get across. At the outset of the class you ask students "Can you bear listening to me? I promise to be no more than fifteen minutes. I swear about this! This is an important article; it really is." You say that you don't want to tell students what it's all about...but I'm the part of you that does! And think of the time you save from trying to figure out how to get them talking.

\section{Adrienne [Student]:}

Yes, but we all sat there in silence for the most part as you explained MacKinnon's article to us as if we couldn't understand it ourselves. For example, you tell us that, ".. a 
big, big issue in the feminist movement" that seems to be talked about more and more is whether the study of women should be approached in terms of their sexual identification, as if the whole world is supposed to be divided into women and men, and women all cohere because they're in this sex defined as woman...or is it more important to consider people in terms of class". And you go on and on, finally telling us that you are simplifying a very complex article. Why presume that students couldn't simplify the article for ourselves, if indeed they need to simplify it? You assume our ignorance, in the light of your knowledge. As you say yourself: "I do want you to understand it..."

\section{Olivia [Academic Feminist]:}

Okay, I see what you're saying. But maybe it's not that I have the authority and privilege of knowledge. If only the students and I would consider ourselves having different knowledges. The woman plumber knows more about the conditions of her life and work than I ever will. I have another kind of knowledge; I may be able to theorize about her position as a woman in the wider socio-political context. But what is this theorizing but another vision of the same experience, which we happen to privilege in academe. Because what we should be doing is approaching knowledge as the one...not just the one vision...but rather a conglomeration of multiple perspectives and visions. 


\section{Adrienne [student]:}

Are you really attending to multiple perspectives by giving so much attention to the auditors in the class?

\section{Olivia [Academic Feminist]:}

I admit that I should have been more careful about the auditors in the class. Although some students enjoyed the contributions coming from women of different ages and experiential backgrounds. But a couple of them did mention to me that they felt that there was a circle for the class and that there were also people who were inside of it in a line or maybe in the back and outside of it, and that was a hierarchial arrangement as well. I think I should have been more attuned to that. I'll tell you quite honestly and I have to realize this more, when you have auditors in your class, sometimes at your own peer level too, you often end up speaking to them or trying to give them the limelight and I think... would not do that again. I think that has been a mistake and if I have auditors I'm going to have to talk to them before and perhaps throughout to emphasize how much I want the group to come together. 


\section{Arthur [Conservative Intellectual]:}

Part of it too is the difference between me and some other instructors. Monica, for example. I tend to let my classes get big and it may be something in me that likes an audience, I don't know. I don't want to think of myself that way but I have to admit that it might be true. When Monica was teaching Feminist Theory 3000 for instance, unless students had Introduction to Women's Studies and one other Women's Studies course, they couldn't take Feminist Theory 3000. So she had a small group. I made a few exceptions this time, people who were taking Eeminist Theory 3000 simultaneously with another prerequisite course could take it if they were upper level ones. A couple of people were afraid to tell me and got by doing it anyway. I let in the auditors and my class was in the high thirties/low forties. Maybe I should have been satisfied with a smaller class and a more discursive group. But I have an alternative motive for doing that too. I like to keep the numbers up in Women's studies, so it's an institutional play I'm making also.

Olivia [Academic Feminist]: Pleasing the father are we?!

\section{A Knowledgeable Woman (Exposition)}

Chloe is highly aware of the knowledge-power nexus that exists as a barrier to dialogue between herself and her students. She wonders how to divorce herself from the 
privilege connected to the relay of knowledge and the power position to which she feels allocated.

Chloe describes herself as "one of the most literate people she knows!" She reads avidly and writes extensively. In the past five years much of Chloe's work has been in the area of feminist literary theory and feminist theories of knowledge. Chloe has become competent in the area of feminist theory, publishing and teaching within that arena of scholarship. Both English majors and Women studies students, who have taken courses from Chloe, speak of her in almost mythical terms! According to them, she is a "wonderful teacher", who can "enthrall an audience", who "knows a lot", and who has a passion for her subject.

Chloe perceives herself as having knowledge. In an interview, she explains that she believes that she has a lot of knowledge that she can impart to her students. She recognizes the danger of this position.

Chloe's students in Feminist Theory 3000 are also aware of the power differential set up between a teacher whom they admire, and enjoy listening to, and they themselves who wish to participate more in classroom discussion. One student, stacey, is concerned with the power relations within Chloe's classroom. Stacey talks about Chloe as a knowledge "broker" of sorts and she compares the classroom process to an exchange. Stacey explains, 
I mean I have information... if you sign up to take the class you want to know this information and I will give you this information.

"Signing up for the course involves payment for 3 credit hours "worth" of knowledge which the teacher duly provides. Part of the problem for Stacey is Chloe's insistence on explication of the assigned reading material each day in class. Stacey is bothered by what she perceives as a teacher who wants to "give" an interpretation of the text. Stacey provides an example,

I think it was the Mackinnon text... she kind of interpreted it for us and that bothered me a lot.

Stacey goes on to say that she is willing to accept the teacher's clarification of issues when clarification is requested by the students. Otherwise, Stacey interprets teacher's explanation as condescending; she sometimes feels "talked down to" by Chloe. As a student in English, Stacey talks about being educated in a tradition which dismissed single interpretation of any text. "All interpretations go", she explains, "so long as one defends one's interpretation to a degree". Interestingly, Stacey suggests that discussion on assigned material might be more productive if participants could reflect on each other's individual's "conversation with the text". For Stacey, "it is hearing other people talk that helps [her] think" and "helps [her] come out wi.th [her] voice". She talks explicitly about coming to Feminist Theory 
3000 to find "a community of people to interact with"; instead, she often finds just "a body of knowledge" being imparted to her.

... When Chloe starts off on her topic she
gets going and you can't stop her. I think
what she says is interesting but I don't
know... sometimes there's so much that you
want to say that you can just go on and on
forever. And it's all interesting but
somehow at the end you feel like no one got
to talk and that's a problem.

Stacey elaborates above on a problem that Chloe herself is aware of, that is, of starting off on a topic and not stopping thus preventing discussion among class participants. At the beginning of the course Chloe tells the students, "If you don't stop and interrupt me, I will go on and on." Chloe punctuates her explication of text with amusing stories. Her stories revolve around Chloe's experiences such as dinner with Mary Daly, a renowned feminist scholar; a lecture by Mankiller, a Native American woman; growing up in New Orleans during the desegregation movement in the fifties and sixties. Chloe is a wonderful story-teller. She modulates her voice and swings her arms about, her eyes dance around the room, holding her audience throughout. She is aware of her ability or power to entertain with her knowledgeable narratives.

Miriam, a history student in Feminist Theory 3000, recognizes Chloe's struggle with her power position, what Miriam terms, the "power/not-power position". She admires Chloe's consciousness of the knowledge-power syndrome but 
comments, "Chloe's conscious of it but she still does it." Miriam sees Chloe as someone who is in the conflict between power and not-power. "Chloe doesn't want to be in a power position, she doesn't want to tell students what it's all about but there's another part of her that does", says Miriam. Miriam is confused by Chloe's explication of text which she feels there is little need for in Feminist Theory 3000; after all, Miriam comments, "Feminist theory tends to engage issues that are personal on some level". Miriam fears that Chloe's explication of text may ultimately destroy the dynamic of the course by "reasserting the hierarchy" between teacher/expert and student/novice.

There is a distinct danger that the relay of knowledge can eliminate the possibility of a community in Feminist Theory 3000 in the process of knowing. Students can begin to perceive the teacher as "all-knowing" and are intimidated by her breadth of knowledge in an area; subsequently, they withdraw from discussion with her. For example, Penny, a psychology student, who never speaks in class, feels intimidated by Chloe, although she realizes that this is not intentional on Chloe's part. Due to this feeling of intimidation Penny is very reluctant to approach Chloe with questions regarding course content. She says, "If there were questions and that kind of thing, I would go to someone else". 
Both Chloe and students wonder if there is any way to break down the "knowledge barriers" between class participants. On the suggestion of Joyce, a history student and concentrator in Women's Studies, Chloe invites four students to lead the class discussion. Stacey, having been absent for one class period, returns to experience a new class format. She is impressed with Chloe's efforts to facilitate students' involvement in the discussion. Stacey comments,
She picked a couple of students. I don't know what happened during the class but a couple of students seem to be the ones that were going to sort of direct the class... that interested me and I thought the discussion was good that day, too.

The class that stacey refers to is one when the assigned reading on "incest" was interpreted by students privately and who then made mini-presentations to the class and led discussion. Stacey sees this class format as successful because of increased interaction among students, without depending on Chloe as discussion director. During the class period in question, Chloe participates as one of a group exploring an issue without striving for any right answers. The teacher's interpretation is one among many. Chloe's struggle to overcome the power position endowed by the relay of knowledge is confounded by the presence of faculty auditors. Rather than enrich the conglomeration of perspectives to which Chloe aspires, some students perceive 
auditors as individuals who possess knowledge on feminist interpretations of issues under consideration. Faculty auditors particularly Alexandra, are quite vocal in class, often dominating the discussions. Moreover, their physical presence in the classroom is problematic for some students--"There is one circle for the class and there were also people outside it..in a hierarchial manner", one student tells Chloe privately.

Chloe admits to have given auditors a lot of air-time, perhaps to the exclusion of regular students. She talks about speaking more to these peer-faculty and giving them the limelight. It is not unwarranted that some students begin to believe that the contributions of professors are more valuable than the students'. Chloe vows that next time there are faculty auditors she will talk to them before class to emphasize how she wants the class group "to come together", to be a cohesive group of individuals participating in discussion.

It seems difficult to get away from the traditional school script to which both teacher and students adhere-that teachers have knowledge and that they transmit it to students. Chloe struggles to rewrite her school. script but finds it difficult to escape the power dynamic created by her own passion for knowledge and sharing of that knowledge.

During one class period, Chloe admits, I keep saying if I know something... it will get me more money, it will get me more respect, 
people will like me better, I don't want to know anymore. It's no fun to know anymore.

She then quotes Susan Griffin's statement: "We may have to love knowledge for its own sake and not as a means to power."

An Institutional Authority (Dialogue)

\section{Arthur [Conservative Intellectual]:}

As a professor you represent the institution to your students. For students teachers can be the all.- knowing "Father", the institutional authority, that they must please, you know.

\section{Olivia [Academic Feminist]:}

I know but I try not to take on that role. I put some effort into establishing a positive and trusting relationship with my students. I framed the requirements for the class so that they might foster dialogue among all of us, me included. Basically, the students have to read quite a bit so there's lots to talk about. I make very few demands on them and I give a lot for class participation. "Give a lot"... I don't give anything. I acknowledge it perhaps. I tell them that I like to have discussions in the class and if they don't interrupt me and ask me to stop talking I shall continue to talk. They write a response to the readings in journals 
which I collect twice or three times during the semester. There was not the usual research paper but an oral project, again so they would get involved with each other in discussion.

When I have to make unilateral decisions--like choice of text--for those I carefully explain my reasons. For example, when I chose three feminist anthologies I explained that...the hallmark of feminist criticism is collections of essays.

Arthur [Conservative Intellectual]:

Eace it we're "in" authoritarian structures when we're in the institution.

Adrienne [student]:

Remember your confrontation with Kelly?

Olivia [Academic Feminist]:

Oh, yes!

Arthur [Conservative Intellectual]:

Please explain to me what happened. 


\section{Adrienne [Student]:}

Well, the exchange between Chloe, the teacher, and Kelly, the student, grew out of a discussion on "Women's studies in the United States", an article by Marilyn Boxer. Chloe had explicated the major points of the essay and then invited students to comment on their own experience of Women's Studies.

\section{Olivia [Academic Feminist]:}

I asked them for complete honesty in their comments.

\section{Adrienne [Student]:}

Yes, and Kelly was being honest when she said:

"I understand .. but something that bothers me is, and it bothered me before, is the kind of assumption that true feminists are connected with certain issues...like... you know, pornography, or you know, fair treatment of animals...."

\section{Olivia [Academic Feminist]:}

I agreed with her statement, that all feminists cannot be connected to "certain" issues.

\section{Adrienne [Student]:}

Then Kelly replied:

"They're not necessarily...but sometimes.... I remember a few days ago we were talking about pornography... and I mean I feel very 
strongly; My view is that... you know, it's a person's choice. But you were saying that you were offended when someone saw censorship as a question of choice. And I felt intimidated to say anything about it."

\section{Olivia [Academic Feminist]:}

At that point I asked Kelly not to feel intimidated. I told her that she shouldn't feel that way. I invited her to speak her mind on the issue of pornography right there and then. "You should say it", I said, "say it now."

\section{Adrienne [student]:}

Kelly chose not to say it and she continued her original line of thought. She said,

"Just like that kind of thing... and there have been other times... also when I would like to say, "I'm not really a feminist... and I don't share that view". That kind of thing... and I mean that's just something that I personally, I guess when I want to get into the class a little while I'll feel more comfortable about saying things. But I feel I'll really offend someone if I disagree with that or that maybe I'm not you, you know."

\section{Olivia [Academic Feminist]:}

Just then I understood completely what Kelly was getting at and I appreciated her saying it. At that time, I immediately didn't want that to happen again.

\section{Arthur [Conservative Intellectual]:}

How did you respond to Kelly? 


\section{Olivia [Academic Feminist]:}

I told her I understood where she was coming from, that it was all the worst because I was saying saying it because she not only had to disagree with someone else in the class but she had to disagree with the instructor who has the power in the class, right? I mean it's true. I told her that I appreciated her saying that.. and that I hoped that we would get back to that.

\section{Adrienne [Student]:}

And then I thanked her. I think that's a good case because here you are, the voice of authority, plus a feminist, because of that she didn't speak up even when she disagreed. Don admitted later on in the same discussion that he was afraid to speak up as the male in the class on something as sensitive as pornography. We feel your authority, we feel that you have some really strong opinions. As Kelly expressed it that day: "I better not say this because we will disagree and you're carrying the class because you're the professor in the class." That's censorship. You were engaging in censorship. I know you don't mean to, perhaps, but the whole university system is behind you saying what students can and can't say to you, as the embodiment of institutional authority and feminism combined. 


\section{An Authoritarian Privilege (Exposition)}

In an attempt to build dialogue in her university classroom, Chloe finds that due to the students' and professors' asymmetrical positions of authority and privilege, dialogue is extremely difficult to achieve.

Students are aware of the teacher's authority in Feminist Theory 3000. One student, Stacey, comments that she came to the class interested in seeing "some ways of breaking down barriers between students and professor". Stacey hoped to see "a class where there wasn't a central point that would be the professor". On arrival in class she finds Chloe sitting at the top of the classroom..."she still sits up at the front near the blackboard and the desk", stacey notices. Stacey suggests that if Chloe positioned herself differently in terms of the classroom's physical layout, then students might think of her less as their "professor".

The physicality of authority in Feminist Theory 3000 is a less subtle form of the institutional authority that pervades classroom discussions and exchange. Miriam, a graduate student in History, suggests that one can never escape the power dynamic of the teacher-student relationship but that perhaps you can be more conscious of it. Miriam remembers the Chloe-Kelly exchange which, she feels, "really 
brought the whole issue of student-teacher power relationships to the fore." Though this incident did not eliminate power-relations, Miriam feels that it worked to undermine them.

The Kelly-Chloe incident raises important issues concerning the possibilities of a dialogic relationship between student and teacher. Herein, may lie problems for the transformative project--the problem of reconciling "differences" in discourses into one, unified transformative voice. In an attempt to achieve dialogue in her university classroom, Elizabeth Ellesworth, concluded that due to "the students and professors asymmetrical positions of difference and privilege", dialogue was both "impossible and undesirable" (Ellesworth, 1989, p.314). Below, Kelly and Chloe discuss the possibilities of a dialogical relationship ever being achieved in their classroom, during a class discussion on the process of Women's Studies.

Kelly and Chloe discuss their dialogical relationship, the possibilities of "democratic communication" between two speaking subjects, they become aware of the power relations that politics and authority constitute, and in which they are immersed. The underlying question of this conversation is: Can you, the academic feminist, my teacher, ever truly dialogue with me, your non/uncertain-feminist, sophmore student? 
We see Kelly expressing her concern with the assumption that "true feminists" are connected with certain issues and certain positions on those issues. She recognizes the teacher as a feminist with "certain" views on pornographyshe is intimidated by the authority of the teacher's politically entrenched position intertwined with the teacher's institutional authority in the classroom. Two discourses, that of institution and feminism, distance or deter Kelly from honest disagreement with Chloe.

Dialogue is not easy to achieve, therefore, between one speaking subject and one silent "subject". Such a state of "uncommunication" in Feminist Theory 3000 reflects a system where the teacher becomes "oppressor" over her students, the oppressed. "Maybe I'm not you", Kelly challenges Chloe--a rather powerful statement of difference--Kelly asserts herself as an "I", though her words would seem to imply that she has felt like an "other", the "not me" of the teacher, Chloe. Chloe accedes, "I mean it's true..you have to disagree with the instructor who has all the power in the class, right?" As Chloe recognizes, and publicly acknowledges, the power differential between kelly and herself, the possibilities of dialogue are increased, there is a beginning of a relationship based on honesty--the teacher's willingness to be self-aware and self-critical and her attempts at being receptive to "difference" between her students and herself. 
Kelly is hopeful that a trusting relationship will grow in time, "I guess when I get into the class a little while I'll feel more comfortable about saying things." It appears that Kelly locates the problem within herself, "I mean that's just something I personally...." she trails off. There seems to be a tension between a materialist analysis of her experience in terms of power relations and the well-documented tendency of women to say that the fault lies with me; a personal quirk.

Though Miriam is thankful to Kelly for "opening up" the class discussion, she feels that "there is still a sense of apology" by students who offer their viewpoints. Miriam imitates the students' apologetic tone--"I don't know if anyone else is going to agree with me on this...but...this is what I'm going to say... and this is what I think."

Chloe is aware of her authority and the influence that it has on students' classroom discourse. Chloe tells me later how "bothered" she is by Kelly's comments. She immediately "wanted that not to happen... and wanted to keep it very open after that". Chloe is upset at Kelly's feeling of intimidation both in terms of teacher authority and feminist discourse. The teacher struggles with the negotiation of teacher-as-facilitator of open classroom dialogue and her implicit institutional authority and explicit feminist politics. 
Chloe's experience in Feminist Theory 3000 underscores the importance of "difference" in the context of dialogue. It may be too simplistic to assume a unified front of subordinated individuals, (students and teacher), against the subordinators (patriarchs), within classroom dialogue. The assumption of "a sharing and trusting "usness" against "themness"" (Ellesworth, 1989) ignores the dynamics of subordination present among participants, as the Kelly-Chloe exchange witnesses, and moreover, within participants "in the form of multiple and contradictory subject positions", as represented by Chloe's inner struggles.

The case of Chloe provides rich evidence of: a subject, a radical pedagogue, struggling with "multiple and contradictory positions", while simultaneously attempting to construct a dialogic classroom with her students. The voices within Chloe find their external manifestation in the concrete distortions and constructions of dialogue among course participants.

\section{Passionate Politics (Dialogue)}

\section{Adrienne [student]:}

You are a feminist already, you have a feminist consciousness; therefore, we are not "equals" in dialogue. The struggle for understanding is imbalanced, I feel. Are you attempting to take me to the place you already are? 


\section{Olivia [Academic Feminist]:}

I know that negotiation very well between the positions of feminist and teacher. It's the thing that I have dealt with more consciously in my mind than any other but also unconsciously in the classroom--what I did in there, everything--when I think about it, it doesn't seem to matter, I just seem to keep acting the way that I've been acting. I am clear that I want the discussions to be open and I want people disagreeing with me.

\section{Adrienne [Student]:}

But what privilege does one have to possess if you have to disagree?

\section{Olivia [Academic Feminist]:}

Obviously, there's a different answer every time. I look at my students as my "unruly daughters". These young women must be both reformed and protected. These women are oppressed. I teach them in Freshmen classes and they're out to please--their peer groups, the guys they know, the other women they know, their parents-- they are out to please. I suppose I'm anxious to share with them a vision that makes a lot of sense to me. 


\section{Adrienne [Student]:}

Did it ever occur to you that the very passion you exhibit about feminism can be exclusionary? I remember one day in class you invoked us to "bring feminist discourse into all our conversations".

\section{olivia [Academic Feminist]:}

But the majority of students in a 3000 level course on Eeminist Theory are more or less convinced on these issues...they've been through at least one other Women's Studies course. Many of them are concentrators.

\section{Adrienne [Student]:}

Perhaps but we're all socialized differently, we all have our different opinions on things... you'd think we'd all be in the same mode of thinking because we're all in Women's studies.

\section{Arthur [Conservative Intellectual]:}

Certainly, I see the existence or development of affinity groups in the classroom to be a direct result of such differences. The affinity group in particular that I refer to here is a group of Women's Studies concentrators who appear a lot more informed than the others on feminist theories and issues.

\section{Adrienne [student]:}


They make some of us feel inadequate in their understanding. I think they must be friends outside of class also and they are the students with whom you seem to be more familiar with, Olivia. It's like they all know each other and know what they're saying to each other. It's like, "Oh yeah, yeah, yeah", and they make common references. Some students feel outside the group and they wish that they could feel more a part of it. Yes, there are many students that are not concentrating in Women's Studies. I'm disappointed in the class because I think we do a lot of man-bashing or male-bashing and I don't really like that. I mean I'm one of the ones that hardly ever shows up but I mean I don't know, I don't feel like there's anything I can contribute.

\section{Olivia [Academic Feminist]:}

I'm not anti-male. I can't continue to express my energy that way. I don't hate men... the men I know would testify to that. I mean I'm sorry that you feel that way. I just don't want to talk about male writers anymore in my classes because that's what we've all learned.

\section{Adrienne [Student]:}

But you'd be surprised by the students who are alienated by that. In fact many times women have approached you and said, "We don't see why you're so hard on the male writers." 


\section{Olivia [Academic Feminist]:}

But I'm really sick of it. A guy in the English department asked me once, "Chloe, I'm really interested in incorporating some women writers in my classes... and I'm particularly interested on those who play around in interesting ways with the theme of marriage." So I proceed to name four or five writers and he says, "I don't know any of these, Chloe. Tell me are they good writers?" I just left. I was furious.

\section{Adrienne [student]:}

Is this a model for dialogue? Isn't this rather extreme?

\section{Arthur [Conservative Intellectual]:}

If I were being political I think I'd rather exr on the side of bending over backwards for some patriarch than not giving the information. Don't you think that's an opportunity for dialogue that you're shutting down the possibilities of change?

\section{Olivia [Academic Feminist]:}

I know. I'm just so sick of it. The job of the oppressed to teach the oppressor about their oppression. These days I think I'd rather risk alienating others.

\section{Adrienne [student]:}

But do you want to risk alienation in your classroom? 


\section{Arthur [Conservative Intellectual]:}

Speaking of avoiding alienation--how did the class on the issue of homosexuality go?

\section{Olivia [Academic Feminist]:}

It's difficult for me to say. I assigned a commentary on Adrienne Rich's article, "On Compulsory Heterosexuality and Lesbian Existence: Defining the Issues". I intended to discuss it like any other piece. I came into the classroom and explained to the students that I was not sure how to deal with the issue in class, that is, in an academic environment. Then I told them that I was a lesbian.

\section{Arthur [Conservative Intellectual]:}

You've never done that before in other Women's Studies classes. That was a first.

\section{Olivia [Academic Feminist]:}

No, but this time I felt I was ready to do it. I had given the idea of self-disclosure some thought. I lied to you (myself) really and to a lot of people about being lesbian because I just concealed it a lot. I guess the reason was that I didn't want people to think differently of me... you 
know. In the last year or so I don't feel the need to conceal it anymore.

In any case I expounded on lesbian women being the backbone of the feminist movement and being its radical dimension.

\section{Adrienne [Student]:}

You also pointed out that there are different ways of defining sexuality. I think that this helped everyone feel more comfortable.

\section{Olivia [Academic Feminist]:}

Yes. The problem is, I explained, that heterosexuality has been made an "institution"; it is the norm and any other choice of sexual preference is abnormal.

\section{Arthur [Conservative Intellectual]:}

Hmm.

\section{Olivia [Academic Feminist]:}

I'd do it differently next time. I would do it from the very beginning--"I am a feminist critic, this is who I am...this is what I do... I'm a lesbian and I, therefore, read certain critiques of heterosexual culture in ways that heterosexual women may not but I hope that all perspectives can be useful. I think that this approach to the discussion would open it 
up more and they may trust me more and be willing to share the personal themselves.

Arthur [Conservative Intellectual]:

Why do it differently?

\section{Olivia [Academic Feminist]:}

I should have spoken about it earlier so the class could proceed on more of a diverse groundswell. Because I allowed lesbianism to be invisible in the course for two months, I contributed to the invisibility of difference. Saying that I am a lesbian is an important act. I mean it's not as if I'm trying to convert them to lesbianism. I'm not. I think they should do as they feel but I'm afraid that if we don't confront them with difference then they'll lose their ability to hear each other, to continue to exist with integrity in relations to each other even when we define ourselves differently. Difference does not have to be painful.

\section{A Passionate Commitment (Exposition)}

Chloe struggles with her role of teacher as facilitator of classroom discussion and her feminist passion. Within the classroom context Chloe struggles with her desire to confront students with important issues, and to challenge them to explore these issues; however, in doing so she is faced with 
the problem of her own feminist passion which students often interpret as impositional and exclusionary.

Chloe, as we have read from her personal history, has made a commitment professionally (as an academic) and personally (as a lesbian) to feminist politics. She finds feminism makes sense to her as a framework for work and life. She often shares her passionate commitment to feminism in the classroom. One aspect of her commitment is her work to transform the curriculum in the university.

Chloe's great concern with curriculum transformation is mirrored in a class discussion on the literature component of the English undergraduate curriculum. She tells the students that she is now unwilling to teach Shakespeare or some other male writers; she is tired of the misogyny in their texts, weary of their male discourse. Chloe admits to the students of Feminist Theory 3000 that by including only women writers in her English courses she risks alienating her students but this is a risk she must take. Chloe realizes that she can no longer continue to be angry and negative in her literary criticism. "I want to channel my energies in more positive directions", she tells the class. Tangentially, she explains, that she has stopped subscribing to the New York Times Book Review due the meager attention that journal pays to women writers. Instead, she now uses the Woman's Review of Books as her catalogue and guide. 
Chloe's position as ardent academic feminist has two very different effects in the context of the Feminist Theory course. Some students admire her stance and find that when confronted by it they are "pushed against" important issues", especially their own standpoint, intellectually and personally. Yet there is an opposite response, some students feel "pushed outside" the issues, not feminist enough, or simply imposed upon by Chloe's "preaching". Both student responses are important because they raise the issue of "phases" in terms of adherence to feminism. Chloe introduces the notion of "phases" in feminism during a class period. She says,

I think that we all go through different phases on this. Some have been in Women and Creativity, or another feminist theory class, or some other classes...Alexandra's in a graduate class and is teaching some... and I think that they're all different levels. And I think that I'm sort of at the stage where I have ten years of professorial teaching behind me and I think my perspectives are a little different from some of yours. I'm sick of the male discourse. I know some of my male colleagues who are sick of it, too. It's not just something that a woman feels.

Two students, Penny and Miriam, represent two very different reactions to Chloe and the feminist discourse she introduces into the classroom. Chloe interprets differential responses such as these as representative of different "levels" or "phases" that individuals may pass through in their commitment to feminism. Because Penny does not share 
the passionate commitment of Chloe, problems arise for Penny that lead her to "opt out" of any dialogue with the teacher. Miriam is a graduate student in History "sitting-in" on Eeminist Theory 3000. Miriam describes herself as "someone who likes ideas" and is very comfortable in academe. Miriam describes herself, also, as someone who lives life and conducts her work in a very linear, analytical and goal-oriented fashion. Describing this model as a "safe" one, Miriam admits to having suppressed "all the stuff" that she is unsure of in her personal life. She recalls growing up "completely white, completely middle or upper-middle class, and academic". Miriam refers to her childhood social sphere as a "privileged space" and wonders how not necessarily to cope with such privilege but "how to understand it, how to decide if that's what [she] wants." Miriam is led to reflect on her own positionality and ultimately to a realization of her privilege. Miriam concludes,

I think more than anything it's a realization of choice for me and given that choice what am I going to do with it.

Miriam has also felt confronted in terms of her own academic scholarship. Beginning to explore dissertation topics Miriam has felt encouraged to make "gender" a central construct of her historical research. "Not a day goes by", she says, "without making connections between my work and what's being spoken about in Eeminist Theory 3000 . Miriam 
begins to develop a critical perception of what began as an academic problem--her dissertation topic. No longer is the research problem the only issue of importance for her; now she considers epistemological questions pertaining to her research methods.

Prior to Feminist Theory 3000, Miriam had decided to focus her dissertation on courtesans in Renaissance France. Now she realizes that on one level this research project could be "a story about men, by men, for men, even though it's about women's bodies." Newly aware of this possibility Miriam raises new questions within her topic area.

I want to find a space for women's worcls, for women. Is there a space, does it exist, or is it simply what we've been always told, or is there a way of reworking that so that women's space is actually there.

Miriam wants her work to do more than explore an idea in history, she now speaks in terms of asserting a space and power for women-courtesans-in her research.

Miriam's experience of Feminist Theory 3000 is one of feeling "pushed against the issues". She describes how she has had to confront her fears about where she will go, and how she will operate, in a world where problems of racism, sexism, classism and homophobia predominate.

Miriams's response to Chloe's classroom process is a passionate and emotional one. She compares her experience in Feminist Theory 3000 to being near a "volcano" all semester. However, she is unthreatened by the "volcano"! 
I'm not so threatened by it now... reasly because being near a volcano can be terribly terrifying...but I have this sense that it's a good volcano... that I can handle it and I'm not going to be dessimated by it.

Miriam feels that if she had experienced this class early in her college career that it would have felt threatening and intimidating. At this point, when she is "All But Dissertation" she can handle it and even enjoy it.

Penny is an undergraduate junior in psychology. Penny has a very different reaction to Chloe and the classroom discourse of Eeminist Theory 3000. She feels excluded-"pushed out", so to speak.

Unlike Miriam, Penny has taken two other Women's Studies courses--Introduction to Women's studies and Women and Creativity. Penny doesn't enjoy Eeminist Theory 3000 because she feels pressured by Chloe's feminist passion. Penny describes Chloe as having "modified" her feminist opinions somewhat since a previous encounter, when Chloe taught some of her Introduction course classes. However, for Penny, Chloe is still too "do-do-do" regarding feminism and inflexible in her opinions.

One example of her problem with Chloe that Penny presents is Chloe's tendency to "male-bash". "Men are an important part of my life", says Penny, and so she is reluctant to be too harsh on them, as she perceives Chloe and other class members to be. 
Penny pinpoints Chloe's tendency to tell rather negative stories about her dealings with the administration while acting as Interim Coordinator of the Women's Studies Program. These stories usually refer to male administrators, with whom Chloe has found it impossible to work. Though Penny realizes that Chloe is "striking out against a certain mentality" rather than specific individuals, she is upset at these stories. Because of Penny's feelings about the male-bashing discourse of Eeminist Theory 3000, she feels that there is little that she can contribute to classroom exchange; so she decides not to show up for class and if she does she is always silent.

Throughout our interview, Penny expresses a feeling of being "outside of things" in the classroom. She feels that "a lot of people in the class are looking at things from a different perspective". In fact she says, she might as well be a man in the room insofar as her views compare to some participants.

Part of Penny's feelings of exclusion can be attributed to the emergence of an affinity group within the main classroom group. The affinity group is made up of concentrators in Women's Studies, that is, those students who take a series of six courses and achieve a "concentration" in that area. Many of the concentrators are English majors also and so have had the opportunity to get to know one another. Chloe is very familiar with these students, both as 
their Women's Studies and English professor. These students converse freely with Chloe inside the classroom. The concentrators share Chloe's passionate feminist standpoint. According to Penny they too participate in the male-bashing scenarios. Her response to this affinity group can be summed up as follows,

You feel like if you don't wholeheartedly subscribe to their ideas and stuff, you know, you aren't a feminist and you don't believe in equality for women. I mean you just feel like an outsider.

Penny has a commitment to feminism since an early age when her mother took her to abortion rallies in Washington D.C. Yet the "feminism" of Chloe and the affinity group is not her "kind" of feminism, she feels. Penny leaves Feminist Theory 3000 imaging Chloe's feminist vision as one that seeks to invert the present system, and build one where "women are better and we're going to take over power from men". This vision is "silly" according to Penny. She concludes, "How do we ever expect men to take us seriously or take Women's Studies seriously if we're not going to try to include them?"

How does a teacher deal with these multiple positions in the classroom? Penny's commitment to feminism takes on different proportions to Chloe's. As a teacher in an educational setting should Chloe take Penny's position into consideration during class and "tone down" her belief system so as to prevent alienation? If Chloe presents herself less passionately on an issue how will students like those in the 
affinity group of Women's Studies concentrators react--will they feel "betrayed" by Chloe? And will Chloe have been true to herself as an individual and as someone in relationship to her students?

None of these questions are easy for Chloe to answer but an action that she takes at the end of the semester has an interesting effect on students who take Penny's position. Chloe tells the class that she is a lesbian, as part of her introduction to the essay, "On Compulsory Heterosexuality and Lesbian Existence: Defining the Issues". For Joan, whose response to Chloe [shared in an interview] mirrors that of Penny's, this was an important event. Joan, an African-American undergraduate in Political Science, traces her impression of Chloe from the beginning of the semester to the class on homosexuality, which is one of the last class periods. She says,

I think at the beginning of the class because she was so passionate about the "this and that" she was talking about, I was trying to sit back and think whether she was really a radical person, you know; whether she was going to have this strict way of thinking and condemn everything else....

....But you know just listening to her talk
in class yesterday. I mean she just seemed
kind of open.... I guess yesterday I got a
different impression of her. I think I like
her. I don't agree with everything she says
but I think she was really nervous telling
us about it.

For Joan, Chloe's self-disclosure rendered her vulnerable"nervous". Chloe seems less imposing, more of an ordinary 
human being. Unwittingly, perhaps, Chloe may find that her often conflicting role of teacher/facilitator with her role of feminist can be reconciled in displaying the "person" behind both roles. 


\title{
CASE 3
}

\section{Introduction}

\author{
"I am a feminist and a post-structuralist" \\ Gale
}

Five years ago Gale would probably not have referred to herself in these terms. However, Gale has gone through a major transition in her life that has moved her from the private life of home to the public life of the university. This transition is immensely important in understanding Gale's search for personal autonomy and her continuous struggle to maintain such autonomy, in the leadership roles of academic feminist and university teacher.

Understanding Gale in terms of her transition from the private to the public realms of experience, leads me to make a number of assertions about this teacher. First, Gale uncovers a different dimension of herself--the intellectual--through a series of particular life experiences. Second, the intellectual domain takes Gale into the public sphere of the university wherein she sees rich possibilities for her growth in terms of autonomy and leadership. However, Gale finds herself still searching for an autonomous sense of self--as a teacher faced with a complex classroom process; and as an academic feminist whose 
transformative efforts are thwarted by what she perceives as an unfriendly institution in which she feels extremely vulnerable.

I explore Gale's transition from the private to the public realm by examining four dimensions of this transition. First, I lay out Gale's personal history to date. Secondly, I move on to the present and her teaching of a Women's Studies Senior Seminar called, Women and Representation. During this seminar it becomes clear that Gale is struggling to gain control of the public realm of the university. Gale struggles with "knowledge" which she perceives as a teacher's route to an autonomous self; she struggles with the presence of faculty auditors whose authority she feels; she struggles with students whose silence she cannot understand; concomitantly, she struggles with the negotiation of the person-teacher boundary. Finally, I explore the feelings of vulnerability that Gale expresses in terms of her relationship, as an academic feminist, with the university institution and those who represent it. Gale's struggles within the public realm reflect her continuing search for autonomy as an individual. 


\section{Personal History: A New Dimension}

Having grown up in a Mormon family Gale learned from an early age that the role of women was "a supportive, emotional, privatized role" that left her wondering, "what to do with the rest of me?" She described her experiences as follows,

The factor for me was that I was raised in a Mormon family. ....And there were all these expectations. I mean the kind of expectations for a woman in the Mormon church are very...very prescribed and I just wasn't comfortable. I mean I really envied people. I mean I always felt perplexed. This role is so..."there"... so obvious what it was supposed to be. And it seemed to me so.... of course, I could do it...but it just seemed like... What would I do with the rest of me. [Gale laughs]

I just couldn't figure out what to do with my mind... or my interest in leadership. I just have sort of a leadership impulse I mean I'm interested in being with groups of people and making decisions with groups of people and taking leadership roles in real ways in the world, consequently. And that wasn't supposed to be. I wasn't supposed to have a public leadership role. I was supposed to have a supportive, privatized, emotional role and it seemed that I couldn't account for by choice.

Gale grew up unable to articulate, but sensing, the tension between the expectation that she lead a private life and her own desire for leadership and autonomy in the public sphere. She continued, 
It was a struggle. I was aware of it but I couldn't articulate it because I'm really...that was a long time ago.

Part of the private-public tension was reflected in her differentiation between "insights" and "arguments". Gale felt that as a woman she was allowed to have insights but never arguments, the latter would have represented a "position", a "standpoint", part of what is associated with a "public" self.

I mean I was socialized not to have arguments. I was socialized to have things like... I mean an argument is you have a position in a public sense; you've taken a stand. You're staking your identity on it and you'll stand there with your idea and your argument and that's all public things. Those are the things that are in the public domain... and I was never supposed to have anything. ...I could use my insights and internalize them to play out the roles that I was supposed to play.

Gale's private-public tension was further highlighted by her relationship with her mother.

My own mother gave me very contradictory messages...because she was a Mormon and she also had to work. That was always a conflict for her but nevertheless I saw her--this very successful secretary and very hard worker, and very successful, independent woman--a part of herself that she won't claim because she wasn't supposed to be that, she had to do that to earn money, "Wasn't that too bad?" But you see I didn't read it that way. I read it as a model of a woman who could go out in the world and could be very successful and get what she wanted out of her job. That's not...she didn't realize that she was giving me that.... 
Gale's mother inadvertently modeled the notion of "a successful, independent woman" for her daughter. Gale paid attention and was attracted to her mother's public role. Simultaneously, Gale received messages that a woman should remain at home, in a more private world; it is only in unfortunate circumstances [usually pecuniary] that a woman, who is both wife and mother, should work.

Gradually, Gale came to terms with the Mormon church and began to figure out her own choices.

I think a lot of it was coming to terms with the Mormon church, that's for sure. There was lots of time to figure that out. So feminism was, you know, really helpful. It was very important to me. Although I broke away from the Mormon church little by little...

However, some of Gale's choices continued to be unsatisfactory to her.

I was a high school teacher and that wasn't enough for me either. So I was always putting myself in roles that weren' $t$ enough for me, 'cause I had no guidance. There were no role models in my family and certainly no expectation. So I was doing everything against everyone. So that really aids iny feminist politics. [She laughs] And so I feel like you know, I've always been in this marginal position. Right now it's a struggle for me to feel that I don't always have to feel marginal, that I have a right to the institution itself, that I don't always have to inscribe myself marginally. And I was a high school teacher for about six years and I felt like that there was a lot more about literature that I didn't know because it just wasn't enough. 
on the occasion of her first pregnancy Gale decided to return to college, to work toward a master's degree. She explained,

And I was basically living in the suburbs then and my husband then was a high school teacher and I was a high school teacher and that's how we met. And so I figured I could go to graduate school as I was pregnant and I had to take care of my child anyway. And so I could justify more education as sort of something to think about while I was taking care of my.... I mean I couldn't claim it really as my own...

Gale came "around to it in terms of this other role of wife and mother" which was "really the role that was [her] role". Continuing to attend graduate school, while taking care of her child and pregnant with a second, was challenging, to say the least. Gale described her process,
It was hard, I was so big. [she laughs] Well, the first semester, I remember in December, I was about...he was born on January 31st, and I remember sitting at the typewriter typing my papers that first quarter. It was just physically very unpleasant. So, I took a lot of leaves and I went part-time and then I took my masters exams five years later when I was pregnant with my second child. And that was really....it was like eight and a half months pregnant when I took my written exams.

Gale completed her master's degree while she "took care of [her] children". However, she found that she could be highly successful in academe. Upon this realization, graduate school constituted "a very important transition" for Gale. She felt that she could now "come to terms with who [she] was", with the help of "wonderful professors". 
... I had people who didn't pay attention to all these things. They were interested in my mind and my ideas and the development of my opinions and the development of my intellect,... and myself as a critic.

Gale began to realize that she didn't have to inscribe herself marginally any longer; she found a place where she could feel a "person", more "fully human", to use Friere's term, perhaps. However, Gale was still reluctant to claim any part of her academic experience for herself.

I was so reluctant to claim any of this for myself and they would just give it to me, practically, you know. I did have to claim it for myself. They can't give it all to me...but they took me seriously as a person, or as a student or as something like that.

Gale's success in the university encouraged her to continue in graduate school, this time toward a Ph.D. degree.

So I did very well in graduate school and everyone was sort of asking me was I going to get a Ph.D. and I..."Well, am I?" So, I thought, "Well alright... I might as well do that too." And so then I applied to be a TA and my daughter was about $21 / 2$ when she could be in day-care and then, I was a teaching assistant.

Ironically, perhaps, she described herself as continuing to play the role of a "very obedient daughter". Gale was a very diligent student, always anxious and ready to do what was asked of her by her teachers. For example, she read all materials suggested by professors without ever considering that a selection of readings might be more appropriate. 
And then, I don't know, I started taking courses, you know, I was always a very obedient daughter and that's another role. So I'd go into a graduate course with the syllabus and I couldn't wait to read everything and listen to every word the professor said...totally uncritically, you know.... "Oh let me please you and of course, I would please them...

Gale's anxiety, almost, to learn and to gain the knowledge which would lead her to a greater sense of who she is, prompted an "uncritical" approach, on her part, to the subject matter of her courses. Thirsty for knowledge her teachers could provide, she continued to drink undiscerningly until...

There were two particular incidents which eventually roused Gale from her uncritical obedience as a student. First of all, Gale wrote an excellent final examination paper for one of her graduate courses. Several weeks later, the professor of the course approached her to explain that he had used some of her ideas in a paper which he was about to publish. Initially, Gale was extremely flattered by his remarks; later on she came to a political analysis of her professor's plagiarism. She was stunned by the realization.

I had this one professor who said, "On the exam you wrote, you explained something so well that I, I sort of used it in this article I wrote." I was so happy that they'd...not really thinking that this person was trying to cover himself for lifting my ideas. And I just felt like, "Oh, please take more, take more." [She laughs] I was so stupid. 
The second significant event for Gale took place in the context of a literary theory class in which she discovered contemporary literary theory to be "incredibly sexist".

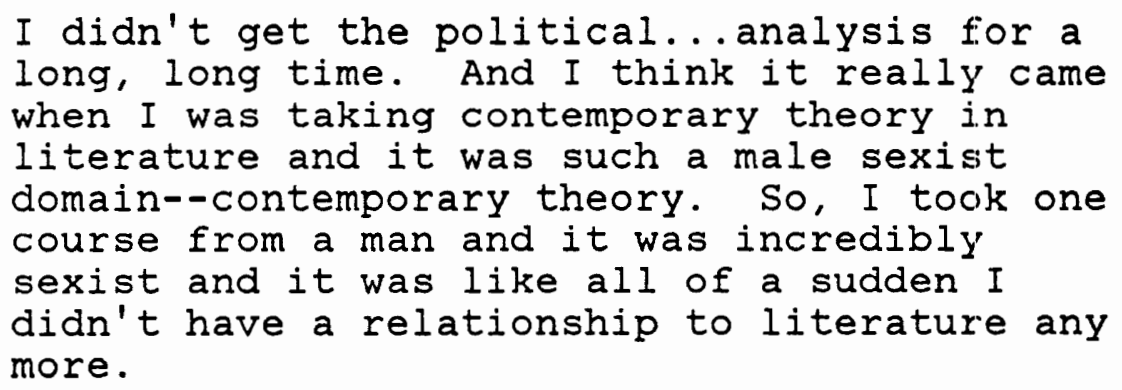

Gale began to realize that as a literary theorist she must look at literature through a "male" lens. Literature, it seemed to Gale, at that juncture, didn't really belong to her as a woman. For Gale this new found realization was startling because she had "always read for a very young age". Literature had provided a place "where she had put that part of her that didn't fit any place else". The awareness that she no longer had privy to this "place", simply "because she was a woman", constituted a "moment of psychic disequilibrium", which Adrienne Rich describes as looking in a mirror and not seeing oneself. Gale explained her feeling,

I'd always read from a very young age... and it was sort of the part of me... it was where I put the part of me that didn't fit any place else. And all of a sudden, I couldn't have that and this made me.... And by this time I'd worked out many other kinds of things and I just couldn't believe that, I just couldn't believe. So I went to the graduate chair and she eventually directed my dissertation. She was a feminist scholar and she could listen to me. She let me do an independent study the next semester instead of taking the next 
[course] in the sequence. And I did an

independent study in feminist theory.

Gale's analysis of the field of literary criticism had wider implications for her newfound intellectual life. She realized that though she had gained access to the institution, to new ideas and to her own intellect, the university was really a place inscribed on her behalf but not directly by her. She may have had access to knowledge, but it was a knowledge woven in threads of sexism, binding her to her well-worn place at the margins.

However, Gale learned something else from her experiences in the institution--she began to recognize the the essentially artificial and constructed nature of knowledge and also, the possibilities of feminist theory, as a vehicle of critique.

I felt that there was so much more to be said. I suddenly saw... I suddenly started to put things together... what I could say or what I could do and what I could bring to literary studies...basically from reading post-structuralist feminism.

Paradoxically, Gale found a theory that helped her "clarify and critique" existing literary theories, but that very theory inscribed her marginally in terms of "malestream" literary theory.

Post-structuralist theory is a whole different way of thinking and looking at the world and I didn't realize that there were people who weren't where I was. 
She continued to work with post-structuralist theory and she wrote her doctoral dissertation, using it as her theoretical framework. But theory, for Gale, has become even more than a tool of clarification and critique. Her graduate experience has "giant implications" for her personal life.

... I went through a divorce in the middle of writing a dissertation because all of this had giant implications for my personal life. It's really hard... I don't recommend that!

Also, Gale began to realize that there were certain social expectations particular to her as a woman. She was watchful and determined not to allow what she calls "the myth of mothering" to take hold in her own life.

\begin{abstract}
There's a whole myth of mothering in our culture that's very dangerous for women to buy into--that it is your identity or that you can do it. You can't do mothering... you can't be.... To be a mother in our culture means to be ever present and ever supportive; that's an impossible role for a human being, that's an unhuman role. And so I don't... I try not to take on the unhumanness of the role. And my children... you just have to not feel guilty about not being there every minute for your children. They're not going to suffer; that's not what they get from you.
\end{abstract}

The woman who once saw graduate school as something to do while raising her children, can now claim the university as a "room of her own". Gale moved, with her two children, from the West to the East coast, to take up a joint position of English and Humanities, in a southern university, in the hope, at last, that this role would be "enough". Her opportunity for leadership was near. 


\section{Women and Representation 4000 - Vignette}

\section{Journal Entry}

August 22, 1989

Today I met Gale, the teacher of Women and Representation 4000, the Senior Seminar, for the first time. We had spoken briefly on the telephone last June but then went our separate ways over the summer months. Now it is Fall and school has begun. I headed across the drill field this morning at 10:50 a.m., toward Paeton Hall, where we were to have our first class meeting.

I arrived in Paeton Hall a little early and had time to look around. I decided almost instantly that this was a rather unlikely room for a seminar. It was large enough to fit at least sixty students and I didn't expect more than ten in this seminar. I had just sat down at one of the old wooden desks when Fay, a student from my Feminist Theory class last Spring, arrived. We talked for a while and watched other students arrive. Then, Kathy who had been in Introduction to Women's Studies, almost a year ago now, entered the room. She seemed an outgoing individual, an English major like Fay, and a writer for the campus newspaper. Then, two women arrived together. I later found out that they were Ruth and 
Mary. Ruth is a graduate student in English while Mary is a senior in International Studies. Both sat quietly at desks, rummaging through their book bags for books and folders, I imagined. Neither exchanged any greetings with those of us already there, but they did smile. I felt that I knew Ruth from somewhere; later I realized she too had taken "Eeminist Theory" with me, a year ago.

In the meantime, Gale had arrived with a young man carrying a film projector. He set it down on the floor and left. I had felt rather apprehensive about meeting Gale initially. My fears subsided now. I introduced myself and she seemed very happy to have me in the classroom. I thanked her for the opportunity. She is in her mid-forties. I noticed her book bag was more like a student's than the usual professor's briefcase.

As the remaining students, Lesley, and Rose arrived, I noted Gale's reaction to them as very warm and friendly. Rose was a psychology major, in her senior year while Lesley was in Eoreign Languages and English.

On Gale's request we set our chairs in a semi-circle and made name-cards for ourselves, so we could get to know each other quickly. Just before we got started three women arrived in the doorway--faculty auditors. These women later on introduced themselves as: Pauline, the coordinator of the Women's Studies Program; Lisa, a beginning professor in 
Foreign Languages; and Beth a colleague and friend of Gale from the English department.

All introductions complete we surveyed the syllabus. The movies, theory and novels looked interesting. I began to look forward to sitting in on "Women and Representation"...

\section{A Public Transition}

Gale feels that she has found, in the university, a place where she can assert her autonomy and leadership skills. Gale sets out to make her contribution to literary studies by critiquing them through a feminist post- structuralist lens. Her critique constitutes a transformative agenda in terms of teaching and scholarship.

Gale designs the course syllabus of the Women and Representation Senior Seminar to meet a specific learning objective.

The aim of the course is to learn some contemporary ways of questioning and responding to the representation of women.

In other words, the students in the seminar will acquire knowledge outside their immediate experience, [contemporary ways of knowing is a euphemism for post- structuralist theory] which they can then use to interrogate one particular aspect of dominant, patriarchal, western culture--the representation of women--and subsequently, redefine current representations and construct different ones. Four methods 
of inquiry are used to structure the process of knowledge acquisition towards these ends; these approaches are described in the syllabus as follows,

Eirst, we'll consider the representation of the female mulatto in American society to see what this figure can show us about representation in general. Second, we'll examine major essays that emerged from an intense feminist inquiry in the place of woman in cinematic representation [includes film series]. Then, we'll read essays by two major post- structuralist theorists to understand what they can tell us about the place of the feminine and the maternal in our culture. Finally, we will read four novels to see on what grounds each novelist configures the representation of women and also to discover how feminist theories of representation can inform our reading.

Thus, when students learn post-structurlist theories of representation they take heretofore taken-for-granted cultural representations of women in art (cinema, theatre, paintings) and literature, and they begin to understand how such representations perpetuate repressive notions of "woman" as "maternal" or "feminine". What was once ordinary to us, (for example, cinematic representation of the female mulatto in Classical Hollywood cinema), now seen in the context of patriarchal repressive myths about women, seems extraordinary and unacceptable, (the mulatto, as a black woman wishing to be that which society unjustly assumes and portrays as superior intellectually, socially, and economically, that is, "white"). 
The overarching theme of Gale's scholarly work is narrative constructions of sexual difference in film and literature. Gale views the Senior Seminar on Women and Representation as a learning opportunity for herself as well as her students. She explains this to the students at the beginning of the semester,

I have promised three chapters and an introduction on this [she laughs] by next July. So I designed the class so that I could get some information from you [she laughs again] because I think that feminist theories of narrative are very interesting.

The Women and Representation seminar starts out as any other seminar might, students and teacher involve themselves in discussion; in this case, on Classical Hollywood film. However, as the semester proceeds and seminar participants delve into post-structuralist theory, the dynamics of the Senior Seminar become increasingly problematic for Gale. Her struggle for autonomy and leadership in the public realm combines with her students' particular approach to the classroom to create a complex arena of teaching and learning. 


\section{Film Viewing - Vignette}

\section{Journal Entry}

August 29,1989

It's been just a week since I first joined the class "Women and Representation 4000". Lee has left due to some unforeseen professional commitment. Lesley stjll comes but on an irregular basis. She has dropped the course officially.

Today, we began discussion on the work of film director, $\mathrm{J}$. Stahl, in the context of the movie Imitation of Life. It was 11 a.m. Rose, a psychology major, lisa, a faculty auditor, Lesley, from English and Foreign Languages, Kathy, Fay, Ruth--all English majors, Mary from International Studies and I sat in a semi-circle facing Gale, who sat with her back to the blackboard. Pauline, coordinator of Women's Studies Program sat just behind Mary, just outside the circle. Behind Pauline lay rows and rows of desks, vacant and silent. The sun streamed in through the windows on Gale's left-hand side. Gale got up from her chair to draw the blinds. We began to view some frames of the movie that we watched in full on Sunday evening last, in one of the university's auditoriums, as part of the Women's studies Film Series organized by Gale. Imitation of Life traced the story of Bee, an aspiring white business woman as she rose 
to fame and fortune. The movie also depicted Bee's struggle as a single mother, and that of her loyal black servant and friend, Dahilia, mother of Peola. Peola, a mulatta, longed to be white, like Bee.

Before rolling the film Gale begins by sharing her reaction to Imitation of Life. "Well, I don't know what your impressions of that movie were but seeing that film, encountering that film, I have a very complex reaction. There was so much that was really important. Let's talk about how gender, class and race come together in John Stahl's version of this story."

"How do race, class and gender come together in this movie?", asks Gale. She continued with a series of questions, "Why does Peola want to be white? That's another way of asking that question. Is race more important than class to Peola?, she finished.

Ruth answered, "Race supersedes all else for Peola." Lisa suggested, "She takes on an identity that others perceive her as ..natural. You are light-skinned and your are thrust into an environment that is white. You are perceived and treated that way."

Gale then asked, "What does she gain by being treated that way?" Then she added, "The difference between Bee and Peola is interesting. What can Bee get to do that Peola can never do?" 
Kathy replied that Bee can move up the ladder from a poor woman to be highly successful and rich and move about in "high society", but Peola is black and the daughter of a servant, both of which prevent that kind of mobility.

Gale agreed and questioned further, "How else does Peola function in Bee's life?

Fay reminded the class of an instance in the film when Bee reprimands Peola for making her mother so unhappy.

Gale extended Fay's comment, "Yes, she puts the breaks on her even more than her mother." Gale laughed, and Lisa, a mother herself, interjected, "But Bee does so as a mother. Bee is always thinking of Peola's behavior in terms of how it's affecting Annie, Peola's mother."

"I'm glad that you brought that up", said Gale, "the mother issue, I mean. I think that the whole "motherdiscourse" is like the bedrock of this film. I mean any film that ends with "Mommy, I want my quack-quack!" Everyone laughed loudly in the classroom. Gale continued laughingly, "That's when I finally lose it, just lose it. It's my disbelief about this film. I mean, it's just beyond me. But it's just not that the film ends with that...the film closes with that... and I think that we need to make a distinction between an "ending" and a "closing" to a representation. The film makes its closure on that line...closure cccurs on that discourse of "mother". Right? Because it brings Bee back to what it means to be a mother. Bee forsakes the man she 
loves for her daughter's sake; the film validates that action."

Lesley suggested, "If the roles were reversed, if Dahlila was Bee, it just wouldn't work." "Yes", agreed Gale.

Mary recalled the scene from the film when Bee first decided to open the store, "When Bee first decided to open that store, selling pancakes and coffee, she was incredibly smart but she was also manipulating a notion of femininity toward her ends. Before she even deals with the man from whom she wishes to rent the store, the camera checks her out completely...her whole body is subjected to one of those totally objectifying scans across it. It's like those kinds of looks men give you..." Mary trailed off, and Lesley begins, "But the black woman, Dahlila, never got objectified in the same manner."

Gale explained, "I think the film is trying to construct notions of gender and race along those terms. When steve Archer, Bee's boyfriend, first meets Bee she tells him, "I'm a woman." Archer replies, "You're not just a woman you are all women." Bee is constructed as the epitome of the ultimate desirable woman. Dahlila is not white, therefore she cannot fit into that mould."

"Getting back to something that Mary raised," said Fay, "Bee exploits Dahlila. Bee went and decided to open up a business without ever asking Dahlila. After all Bee did intend using Dahlila's pancake recipe." 
"Yes", said Rose, "Maybe Dahlila would have said that she would prefer to go on making pancakes in private and not in public."

"Absolutely, I love the scene where Bee comes back to the house and says to Dahlila, "We're starting a pancake business, get your broom". At that point, students and teacher exploded in laughter. Gale continued, "It's just a natural thing for Bee to appropriates the idea, the knowledge, the work, and the image of this other woman. If you're going to exploit someone Bee is a good model."

Pauline, faculty auditor, threw in a question, from her seat behind the classroom circle. "Had the image of Aunt Dahlila existed up to that time?" Gale answered briefly, "It must have."

The discussion continued....

\section{First Moves: Film Viewing - Exposition}

In the foregoing vignette we witness part of a class discussion on John Stahl's film, Imitation of Life. This is one of the five films viewed by seminar participants. The movies are subsequently discussed during class periods against a backdrop of feminist film theory. The particular theoretical essay read prior to class discussion on Imitation of Life is "Visual Pleasure and Narrative 
Cinema", by Laura Mulvey. The excerpt presented below is a representative piece.

In a world ordered by sexual imbalance, pleasure in looking has been split between active/male and passive/female. The determining male gaze projects its phantasy on to the female figure which is stereotyped accordingly. In their traditional exhibitionist role women are simultaneously looked at and displayed, with their appearance coded for strong visual and erotic impact so that they can be said to connote "to-be- looked-at-ness"

$$
\text { (Mulvey, in Penley, 1988) }
$$

Gale leads the discussion of the film by first expressing her own reaction to it. Other participants are encouraged to do likewise. The exchange is for the most part--a-theoretical, at least in an explicit sense. Theoretical phrases and concepts provided by Mulvey's essay, for example, "scopophilic instinct" which means the pleasure taken in looking at another person, are set aside as teacher and students share personal interpretations of Stahl's production. Gale does have an agenda for discussion, however, and she carefully guides the students toward a consideration of the racial issues pertaining to the film: "Why does Peola want to be white?", "Is race more important than class to Peola?" The theme of "motherhood" is also a part of Gale's agenda, which she introduces by asking, "How does Peola function in Bee's life?" Gale's questions are 
answered enthusiastically by students and class discussion is not difficult to facilitate.

As a part of popular culture film provides a medium accessible to students and teacher. Moreover, the teacher's approach to the film viewing and discussion is one that emphasizes personal interpretation rather than indepth theoretical analysis. My analysis here is supported by student response to the film series section of the seminar. For the most part students fail to comment on the film section preferring to speak at length about their problematic experience with the French theory. Kathy is one of those students who comments on the film series at length. She says,

I mean... I loved the film series; I though it was great. Class discussions were good then. I could talk about the films and the theory didn't seem too daunting at the beginning of the semester. I wish we could have done more, perhaps a couple that we could have seen by ourselves... if time would permit it...or if we could have met in the evening.

As the course progresses, Kathy becomes increasingly silent. At the end of the semester she wishes that there could have been more movies which, she implies, might have led to a more discursive class. But Gale's project does not include a semester on feminist film theory. By the beginning of October she has moved onto an examination of Erench theorists--Irigary and Kristeva. 


\section{Interpreting Theory - Vignette}

\section{Journal Entry}

Tuesday October 3, 1989

Today we began to study the French theorists who write from a psychoanalytic framework. I've included an excerpt below,

The move, also reveals, better than any mother ever could that the maternal body is the place of a splitting, which even though hypostatized by Christianity, nonetheless remains a constant factor of social reality. Through a body, destined to insure reproduction of the species, the woman-subject, although under the sway of the paternal function (as symbolizing, speaking subject and like all others), more a filter than anyone else-a thoroughfare, a threshold where nature confronts "culture".

(Kristeva, 1980) We have read an essay, "The Sex Which Is Not One", by Luce Irigary, from her book of the same title, for homework. Gale seemed really anxious to begin. She began, "Today I think we really need to bear down on the issues and really see if we understand them very well... So I put on the board three things that...will be helpful." On the blackboard Gale wrote,

HER PROJECT:

THE FEMININE:

THE PROBLEMS: 
standing at the blackboard Gale announced, "I think that we need to understand what her project is, right?. I think we need to understand what she means by the feminine... and I think we need to understand what the problems are." Gale laughed then, probably realizing well the problems attached to merely reading Irigary.

Then she began again, "okay, now Irigary.... I wanted to say... I got this book on Saturday at "Books Strings and Things"....a book called Between Eeminism and

Psychoanalysis .... This is a fabulous book. This is a book of papers that were... that were worked through at a seminar at Kings College, Cambridge, in 1987...by many feminist theorists that were discussing... Irigary was there... and gave a paper. Her paper was called "The Gesture and Psychoanalysis"...ah, a woman philosopher called Margaret Whitworth has this wonderful article called "Rereading Irigary", that a lot of what I'm going to talk today comes from. But in any case these women got together and they said, that there are some impasses in feminist theory, there are some impasses in the use of feminist theory...ah, in a practical sense.. which somehow seem to be getting coopted all over the place... what is the political agenda of this kind of theory anyway? And they worked through, in a theoretical sense, some very important impasses and conundrums and it's splendid because it's not... it doesn't seem to be repetitive at all of of...things.... It's moving forward in some 
senses. I've just had a chance to start looking at it... and I read the Irigary for today....

So let's see if we can define Irigary's project. I'm really getting more interested in it than my first impression...that I spoke of last time. Let's talk about the title of this book This Sex Which Is Not one Could you explain to me the references to this title, the pun in this title?" There was silence. "The French title is about the same..."The Sex Which Is Not one"... what does that mean? Silence again resounded.

Then Ruth contributed, "She's talking about the fact that women have not been recognized as having any sexuality."

Gale responded, "So women are the sex without one...." Everyone laughed. "That's one meaning... what other meanings are there? "The Sex Which Is Not one", questioned Gale.

Kathy suggested, "The sex which isn't a sex because you aren't really a sex...unless...you're in the shadow of a man".

Gale repeated Kathy's words, "The sex which isn't a sex... is that what you are thinking more or less...okay...a sex which isn't really a sex. It's just a reflection or the opposite or the opposition to male sexuality...another version of that. Okay what's another sense?"

Mary commented, "A sex that is multiple."

Again Gale repeated, "More than one...multiple. Irigary talks about westernized metaphysics as a metaphysics of the 
same. Gale went to the blackboard and writes: METAPHYSICS OF THE SAME.

From her standing position at the board Gale explained, "In some other reading..this essay, "The Sex Which Is Not one", is just this whole discussion of how it is that femininity, or the feminine, becomes subsumed in the masculine. It's not sexual difference, it's sexual indifference. So the problem is that western metaphysics seems to be ah...caught up in the... in a notion of difference that's always going to posit things in binary ways...one thing as opposed to another thing... which is a way of cancelling out real difference."

Gale continued, "Okay she's...that's one way of understanding her project.... So, what do you think she's trying to do? How would you define her project. . what do you sense she's trying to accomplish with her thinking, with her writing. . ?"

Laura, a faculty auditor began to speak, "She talks about one thing being valid, that is, the male to experience physical pleasure and for a woman--the woman is supposed to fill that gap, that female pleasure. She talks about various ways that female bodies can be interpreted that isn't that the woman is defined in relation to the male."

Gale agreed with Lisa, "Okay...so she wants new representation" 
Lisa interjected, "She wants new representation of the body.. as a dome of pleasure for the woman."

Gale wrote on the blackboard, NEW REPRESENTATION OF WOMEN'S BODIES, while simultaneously asking, "Anyone else have a way of coming at this for understanding this?" There was silence from the group. Gale asked encouragingly, "Were you going to say something, Fay?"

Fay responded in a quiet tone of voice, "Well she's not...first anomaly of the definition of femininity...she kind of steps into this very negative space that women have been given and that's where she's working from... she's using that as her position to crack... the mould...."

Gale was estatic! "Excellent...that's absolutely excellent.. she's working from the inside of... of a place ...she's working from th inside of the symbolic order ...she's working to dismantle it from the inside.... She's not stepping out of it.. and saying, let's create an alternative...is that what you're saying?"

Fay answered, "Yeah."

Gale continued, "I think that's right. Okay, so she wants to ...dismantle the symbolic order from the inside." Again, Gale writes on the blackboard: DISMANTLE: SYMBOLIC ORDER FROM THE INSIDE

Gale inquired of the rest of the class, "Do the rest of you agree that she's there? This Margaret Whitworth article talks about the project in terms of the relationship to the 
physical to the psychic, and the social and she says that the problem.... I mean it's a practical problem...this isn't an abstract, remote problem...this is a real problem for women in that am...psychic life really doesn't match social life...there's no match...there's no very satisfactory match for women..in our culture... O Our psychic lives and social institutions just don't join up in the right way [laughs] therefore she says...that women are prey to many things.... I love this..this way of talking about what the problem is for women... in this Margaret Whitfield article... She says, "Women are prey to interminable rivalry with each other". This is a real problem for women...the qualms of rivalry that women have with each other... and this list of things that are problems for women are sort of....

It's a very different approach to women than radical feminism proposes...so I want to give you this list of things that Irigary's working on.... The real problems for women in this non-match between psychic life and social life. Okay, because our psychic life...because there's only one version of women that is, the place of the mother, the place of the mother is unique. Right? There's only one place for that to be...so what happens with women is that women have become the mother in our culture but there's no place to relate to each other in that place...it's only "the mother". There's no relation among women in that place in that culture...because it's such a monolithic construction out of 
the metaphysics of the same. Okay? There's no relation with her in that place. So the problem is that really there's just too few depictions, representations of mother-daughter relationships in the culture... It's not enough articulation of that... of that relationship and in fact that relationship is uncivilized. It lies outside the symbolic. Gale stood at the blackboard and wrote: UNSYMBOLIZED RELATION BETWEEN MOTHER AND DAUGHTER, meanwhile explaining, "So in order to... she wants to start from Elles... we talked last time. She wants to start with women among each other but what kind of symbolic representation do we have of that...not very much. We just have a certain notion of the mother and contemporary articulation of mother-daughter themes.... I mean it's exploding all around us. However, it needs to be worked through much more carefully... so that women can relate in that place.

Okay, I think Irigary wants to have a whole different symbolic order, a female imaginary...a female symbolic. She wants to understand the specificity of women in representation... [Gale paused.] So it's a practical question: how to construct a female sociality? How to have representations.? And actually what is needed is.... Gale is at blackboard standing behind chair...students are silently taking notes.... Because this relationship must be symbolized that means that women lack a mediation. Gale 
wrote on the blackboard again: WOMEN LACK A MEDIATION FOR THE OPERATION OE SUBLIMATION....

Suddenly, Gale asked, "Rose, do you follow this?" Rose was slouched in her seat, staring directly in front of her toward the window, instead of the blackboard. Her pen dangled from her hand playfully. She was startled by Gale's question, and answered, "Oh, yes...umm...yeah."

Gale turned to continue writing on the blackboard: DIRECT SEXUAL ENERGY TO SOCIALITY...CULTURALLY ACCEPTABLE AIMS

Lisa raised her hand to question Gale, "Are you saying that there's only one woman...this whole monolithic thing "woman" there's no way for women to relate to each other within that giant monolith. In the movie, Mamie doesn't really have any friends.... All the women in the movie are competing to be the one image."

Gale replied, "okay, so this problem of mediation...it means that women can't really sublimate... and sublimate...do you know what that means in a sort of commonsensical sense what it means to sublimate?"

There is no response from the students. Lisa, a faculty auditor, answered, "It means that you divert sexual energy to social... ah...to sociality I guess...to acceptable...culturally acceptable aims. So women's sexuality sort of lies outside of all this...this dark 
continent...this unknown that feminine...that's so...ah...that we can't be spoken....

Gale replied, "Exactly, Lisa, so the feminine is like the dark continent of culture... the unknown... it has to be unknown for the...to work. It's a prop for a metaphysics of the same."

Having written on the blackboard: "DARK CONTINENT" THE PROP FOR A METAPHYSICS OF THE SAME FRAGMENTED, Gale took a seat and continued her explication of Irigary's essay, "When she talks about the feminine as fragmentation... I mean ...she means it's multiple...it's multiple because it's fragmented. Women's fetishized speech, the fact that women can't make arguments they have insights... I feel like I grew up with very, very feminized program.... It just all worked itself out in my intellectual life in terms of not..being expected or trained to make an argument or rather trained to have insights, little fragments, little things...to say rather than a whole sustained argument that would counter something that would stand on its own and be present there as something. I think...there's just lots of ways...if you think about how the feminine gets constructed as fragmentary...but ah.... The class continued on. 


\section{Interpreting Theory and struggles for Teacher Autonomy - Exposition}

Knowledge: The Teacher's Route to Autonomy?

Gale is torn between establishing her own autonomy as teacher, an autonomy she defines in terms of knowledge of post-structuralist theory, and her desire to empower students to explore the theory. Gale is conscious of her role as a teacher, as someone who should facilitate student participation. However, she is drawn toward the importance, indeed urgency, of her own learning.

Gale is very enthusiastic about French theory. Poststructuralist theory is by its nature difficult to interpret and apply. "I felt swamped in the theory!", says Fay. Anyone who had attempted a reading of psychoanalytic theory (as presented by French theorists) would admit to a certain struggle or at least an intense effort in understanding what appears as a rather "abstract system of thought that could not be appreciated by the philosophically uneducated" (Todd, 1988, p.2). It is indeed difficult, in my view, to relate any empirical "reality", or concrete experience, to "the usually hidden body, the unconscious, the deep structures of culture and language" that constitute the data of psychoanalysis" (Todd, p 51).

Gale encourages students in the seminar to explore the theory in discussion and writing. However, students are 
reluctant to participate in class discussion. Gale's voice is the predominant one in the room as students sit silently and listen to her explanations of French theory. This kind of classroom process is not what Gale intended. She is much more comfortable with the verbal interactions that occurred during the film critiques.

Students become less and less involved orally in classroom discourse, as the semester progresses. Gale finds herself moving steadily into an academic model of teaching where she tries to reinterpret the theory for her self and her students. She is greatly concerned with this development. She expresses it as follows,

And then there's the dynamics of our class; it bothers me a lot. I'd like to take responsibility for it in a sense, because I feel uncomfortable. I'm teaching all this psychoanalytic theory that I've never taught before and it's as overwhelming to me. So I feel like I'm struggling with the material more than I'd like it's wonderful... and I'm learning a lot. This is what's fun about teaching but I feel like I have an obligation to know my material better. I feel like I'm learning too much and I'm not as comfortable with the material so that I can use my energy and my attention to draw students in.

Gale feels that she "should know the theory"; she sees this as her "obligation" as a seminar leader. Gale is also aware that as a teacher there are "many, many things" that she could do, to involve students in discussion.

I often play through the various things that I could do but mostly what I'm thinking about is the material. If I didn't have to think so much about the theory I could maybe use 
it in different ways, or situate myself in it more comfortably, so as to facilitate their coming into it a little more easily.

The theory remains foremost in Gale's mind. As soon as she can feel comfortable with it she will be able to divert her energies into the facilitation of student participation. It is interesting that Gale couches her need to understand the theory in terms of her "obligation". Teaching as an assistant professor is different than teaching as a graduate student for Gale and she struggles with this transition.

I feel that I'm going through this transition of graduate student to assistant professor. It's sort of a difficult transition. I don't feel I've got my feet on the ground in my teaching... as much as I did when I was a graduate student because of the newnesis of the role... and the newness of the material. I'm teaching so much material that I've never taught before... and it's sort of overwhelming to me. So I feel like I'm sort of struggling....

\section{Eaculty Presence: A Threat to Teacher Autonomy?}

Gale feels that her struggle for autonomy is exascerbated in the seminar due to presence of the coordinator of Women's Studies, Pauline. Pauline represents for Gale the lack of openness, or willingness, to learn about post- structuralist theory which Gale has come across in the university generally. Within the classroom context of Women and Representation the authority of the institution is felt by Gale in the guise of the coordinator. 
Gale feels extremely vulnerable due to the presence of coordinator in the classroom. Pauline who admits to detesting "this worshiping at the feet of Lacan!" is "hostile" toward psychoanalytic theory at the outset. As the seminar progresses she becomes less hostile but is still quite skeptical. Her verbal contributions and, interestingly, her physical position outside the class circle, imply a certain authority, what Gale refers to as a "power-play", unintended as it may have been on Pauline's part. Pauline's contributions often lead to a verbal sparring and duelling between herself and Gale, who feels very much on the defensive regarding her position as a post-structuralist feminist.

Gale's response to Lisa, another faculty auditor in the seminar can be contrasted to her response to Pauline. Lisa does not pose a threat to Gale's autonomy. Lisa, another literary scholar of the Renaissance period, is a beginning professor at the university, also; as such her untenured status is similar to Gale's. Moreover, Lisa shows a tremendous willingness to delve into French poststructuralist theory, and converses enthusiastically with Gale. Their conversations are highly theoretical during which Gale often exclaims in delight, "Oh, thank you Lisa, that was really helpful."

Gale seems to be faced with a struggle for autonomy that is twofold. On the one hand, she is grappling with 
knowledge. Her rather rationalist view of knowledge as static entity to be known, by her the teacher, leads her to prioritize "knowing" as a source of autonomy. On the other hand, Gale feels that she is being placed on the defensive, that she must somehow provide evidence that post-structuralist theory is worthwhile and valuable, to those in authority over her who appear hostile to such theory. Life in the public realm of a university classroom does not appear easy or simple. Making matters even more complex, Gale is faced with a group of students who remain silent for the most part. They are complicit in her struggle for autonomy as a professional. She tries to figure out the dynamics.

\section{Teacher Autonomy and Student Silence}

Though Gale sees her learning of the course content as contributing somewhat to the classroom dynamics, which she describes as "rocky", she is still puzzled by the silence of the students. She says,

They are so brilliant, they're such brilliant students really. ...Well, another thing, a puzzlement to me coming to [this university from my own] is just who these are. What this university is like. I'm used to a very liberal arts.... I think that in the students' consciousness, the students who come here, they've ...just... and I think these students in another setting would function very differently in their undergraduate curriculum. Yeah, I do because I don't think they've gone into English courses and they've taken Women's Studies 
courses but I suppose.... The teacher who observed my class had Ruth in his class. And I know some of the professors who've had these students cause I've asked because I've been so puzzled by their silence. And they said that they were the same in their classes.

Gale really tries to understand the nature of the students' silence. Is it due to the non-liberal arts emphasis in a largely scientifically oriented university? Is it the students themselves who appear to be quiet in all their courses? Gale continues to explore the problems of functioning as a woman with a voice in such a male dominated institution,

Well, I think its history, its history as an all male military institution and the people... and the women too, they just don't know how to function with a woman's voice.

The students in the Senior Seminar are equally puzzled by the classroom dynamics. Some students view Gale's classroom as being full of possibilities for their learning. Fay describes the seminar classroom as a place of "so much possibility"; she describes the atmosphere as "floating". Eay contrasts Gale's classroom to others where she feels "uptight and upset" because of the misogynistic tones of class discussions.

Rose feels that Gale responds really well to students comments for the most part. Unsure of the material, Rose says that the few times she spoke she felt that Gale 
incorporated it [her contribution] into the conversation". Pauline, a faculty auditor, agrees with Rose,

I don't think Gale is particularly
intimidating. I mean she's clearly very
bright but I don't think there's anything
scary about her... I Iike the way she's
responsive when people talk....

Gale praises generously when students talk. When Fay, for instance, a student in English, answers one of Gale's questions, she gives an exuberant response. Gale is clearly very, very pleased with Fay's contribution.

"Excellent..that's absolutely excellent", she praises.

Ruth is relieved that like many other Women's Studies courses the seminar "gives you, me, a class with women ...without men talking all the time". Mary enjoys the physicality of the class--the circle.

Like their teacher, Gale, students emphasize the caliber of fellow students in the seminar. This mystifies further, in students' minds, the lack of overt participation. Moreover, students seem frustrated by the silence and the loss of a worthwhile opportunity for learning.

Rose, a psychology major, takes Women's Studies classes because "usually the people who take those kinds of classes are pretty intelligent", and she likes to hear "what they have to say." Now, to her chagrin, she finds that her fellowstudents "don't talk much". Rose decides not to come to class on a regular basis because she feels that she's "not getting much out of the conversation". Frustration is Fay's 
response to the students silence. "There's such a lot of wonderful thinkers in there and I guess that's part of the frustration--why we stay so quiet", she tells me. Ruth also notes the silence in the classroom but resigns herself to it, expressing her willingness to listen as she has "never minded quiet classes."

It may be, in fact, the very caliber of students that keeps them silent. Course participants seem reticent to give an answer which might be incorrect. It is almost as if they are afraid to explore their understandings of poststructuralism, they feel that they must be "certain". Though many students are convinced that theory is important to understand, they are "intimidated" when "plunged into it" by Gale. Mary explains,

The theory is good. As tedious as it is, the section on the theory is the best in the course because it's something that I never had access to before. I think the most necessary thing for me to get out of the class is the theory that I'd not had before.

Sometimes, the best things are not the most positive! Fay believes that in order to fully participate in seminar discussion she needs to know more than she does.

It was just that I felt that I needed to know so much, to be so prepared material-wise before I immediately could launch into some of the things that Gale launched us into.

Mary empathizes with Fay,

The material is so difficult, so inaccessible to me. I don't feel comfortable enough to contribute because I'm not sure that what I'm 
saying is right. I think to myself, "should I say this of am I totally off base?"

Both Fay and Mary draw back from discussion because they feel they don't know enough. They also admit that if they think they do have something to contribute, they worry if it's correct. Repeatedly, students express feelings of stupidity, ... I mean I felt pretty dumb... and no one likes to feel that way... I don't know.. I just don't know why it's not fun for me...

and inadequacy,

I felt when I did speak up... I felt like I could be saying anything. I was just saying anything. I was just saying my opinion. I didn't really know if that had any weight but I said it any way....

Students attempts to get the "right answer" is confounded by Gale's approach to the theory. She expects a very close reading of post-structuralism, which students perceive as a kind of "right answerism". Rose feels that Gale "wants [them] to get certain things out of the book... and she wants to tell us what that is". Also the teacher's questions demand that "you come up with something post-structuralist", according to Rose. Mary's response is similar; because she still does not feel confident that she could produce a "post-structuralist" answer, she avoids meeting with Gale in her office. Ruth seems also aware of a particular reading "privileged over others" that is required in class discussion. She is not surprised as this approach is the one 
predominantly taken by instructors that she's had in the past. Ruth adds, "I know that it shouldn't be that way."

The presence of faculty auditors makes students even more "uncomfortable with their voices". In students' eyes, faculty auditors are knowledgeable about post-structuralist theory. Hence, they are reluctant to display their lack of knowledge in such company. Though Pauline and Lisa sincerely and publicly [in classroom] profess ignorance of the subject matter they are perceived as "knowing". The auditors may be ignorant of the subject matter but but they do possess the confidence, it seems, and the willingness, to ask questions and make comments, whether informed or otherwise. Mary comments,

I think the fact that there are so many auditors in there ..doesn't make us feel comfortable with our own voices in the class because...all have had a little bit more experience with it [theory]...certainly the coordinator of Women's Studies has... so that... I think, makes me feel uncomfortable and I think it does other people.

Much of the class speaking time is monopolized by faculty participants. The students are relegated to the position of spectators; one student, Rose, expresses her feelings of exclusion as follows, ...sometimes I think the conversation between Gale and Lisa gets separated like they're having a conversation....

Mary suggests that "the structure of the content" is more to blame for the silence rather than the class itself, 
as she reflects on the fact that "a lot of people don't have very much to say with the stuff that we've been reading lately". Moreover, she remarks, the "stuff" or "theory" is "very cold" making it "difficult to develop a sort of intimate relationship within the class." Mary goes on to explain that if the theory was more accessible then everyone could relate to it more and subsequently, relate to one another more. The theory has gotten in the way of class relationships, she feels.

Fay recognizes this problem in developing relationships within the seminar and expresses how "distant" she feels from her classmates. Ruth comments on the "little bit of competition" set up between class participants by the material--"I think in some way we're trying to come off pretty well in front of Gale", she says. Students continue, for the most part, not to claim a space and time within which to enter the classroom conversation. Have they become in Lewis and Simon's (1986) terms "prisoners or exiles within a wall of silence?" An interesting development takes place toward the end of the semester. Students who never speak to one another in class begin to meet outside classroom boundaries-both physical and discursive. Mary documents the development,

\footnotetext{
Maybe it was just a matter of seeing people more around campus and talking to them outside of class.... We started talking about how much we don't know what we're doing... I think there's a bonding that has
} 
happened... and we've all talked more about how we felt about the class.. so now I feel more comfortable.... I think that maybe it did develop outside of class and we sort of brought it inside of class and realized that we could talk to each other, that we don't have to sit here.

Fay documents further the development of a new closeness between herself and her classmates toward the end of the semester: "it's only started happening recently and it's in terms of the exchange of small comments and eye contact."

Upon the realization of a common experience of the classroom process, a sense of solidarity begins to empower students to "not just sit there". However, this development does not take place until late in the semester. Meanwhile, students continue to remain silent, and Gale encourages them to explore the theory. Gale works to involve the students in exploring post-structuralism through writing.

The activity of writing takes three forms in Women and Representation 4000. First, there is the portfolio of writing. Each week, and often each class perjod, Gale assigns a writing task to the students. The assignment usually involves a written response to some cultural product--film or novel--informed by a post-structuralist theoretical frame. On one occasion, Gale asked the students to construct their responses to the artifact in question before reading the theoretical interpretation, so as to avoid always depending on the latter. In hindsight, students were asked to reflect on the process of responding without the 
theory and to compare their personal responses to the theoretical interpretations. Gale reads and responds to all written pieces, offering suggestions for revision. At the end of the semester she gathers the portfolio of original written assignments plus the revised work. Gale grades the work, she tells the students, "As it has evolved and as you have revised it and give you a grade for the portfolio of writings you submit." Gale invites students to come to her office if at any time they wish to talk about their writing.

A major class assignment is the Woman Artist Project. The purpose of this project is to give students "an opportunity to study the work of one woman artist (writer, painter, photographer, video artist, film director) in the context of her understanding of issues surrounding the representation of women." Students choose an artist whose work might be available to the class and present a paper discussing "their conception of how the artist understands issues about the representation of women" and also, "what her art reveals about women as representable". Students present drafts of papers for everyone to read and offer suggestions. The final draft is turned in for grading purposes at the end of the course. Again Gale invites students to call at her office to talk with her anytime regarding this project.

Einally, there is a representation project which invites students to become cultural producers themselves, in a conscious way. "The aim is to create a chance to work with 
some of the ideas of the course in an active way", by producing a representation that refers in some way to women. Gale offers some suggestions: "Create a dialogue among the women we say in the films of the course; write an interview between Irigary and Mamie Stover; Create an image of women, or images of women, that expose the place of women in our culture, or which subvert that place and creates a new place-- a new form of representing a woman's body." Accompanying this representation, Gale requires that the students do two pieces of writing done in conjunction with this project. They are: "a 3-5 page description of the process you went through in doing the project; and a 3-5 page explanation of what you think you have done in this representation."

Gale is extremely pleased with the students' response to the various writing projects,

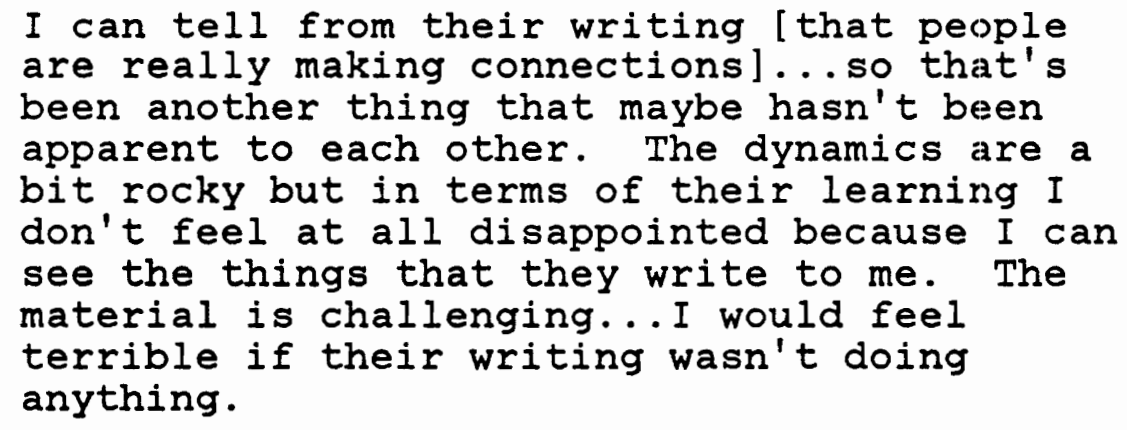
are really making connections]... so that's been another thing that maybe hasn't been apparent to each other. The dynamics are a bit rocky but in terms of their learning I don't feel at all disappointed because I can see the things that they write to me. The material is challenging... I would feel terrible if their writing wasn't doing anything.

The students become more than consumers of poststructuralist theory as the expressive powers of writing take over. Mary feels that "in order for [students] to grasp the theory we have to go through it and write it or whatever". 
By the end of the semester Mary is using post-structuralist theory in other classes as a lens in other written assignments. She explains,
I'm writing a paper for my Women and Creativity class on a woman and I can't get away from this theory and I want to... I don't want to talk about it...cause it's not fun, you know... and this is supposed to be a creative paper... and I just find myself thinking ..."Oh, well...Irigary would like this...but other than that she's not going very far" so I think that it's definitely there in my mind now and I keep thinking about it... and in that respect the course has achieved its objectives.

For Mary the theory may be "not fun" but she has come to an appreciation of, and ability to, use theory as a tool of analysis.

Ruth likes the written assignments and suggests that the course might be a two-semester one because "there is just so much that we could look at".

On a number of occasions students share their writing with their classmates. Gale's explains her rationale for this type of activity,

Well, I looked at your papers and I just thought that they were very interesting. I don't know like this is... short papers everytime with my comments is helping you. I feel like there is a lot of interesting writing emerging and I'm very happy about it. One of the great things about teaching, it's probably why I'm doing so much teaching right now, is that you get to read everybody's ideas and I learn the most because I get to read all the ideas. In a class this small, I think we can all be in that position. 
Kathy is especially pleased with the writing workshop which allows her to hear and respond to the written work of her peers. Students are verbally interacting at last.

$$
\begin{aligned}
& \text {...This workshop... I kind of liked it... . we } \\
& \text { got fair warning that we were going to } \\
& \text { prepare this for our peers and I really like } \\
& \text { to see what everyone else is doing. I just } \\
& \text { live to talk so much... I love hearing } \\
& \text { other people's ideas and since we don't, for } \\
& \text { some reason, do a lot of that in there, the } \\
& \text { papers were really nice. I really understood } \\
& \text { what they were thinking, what they were } \\
& \text { working on and I think everyone in there is } \\
& \text { so bright that I like to hear that. }
\end{aligned}
$$

\section{Negotiating the Person-Teacher Boundary: A Struggle for Autonomy}

Though writing becomes an important means by which students participate in the seminar, it also becomes the site of yet another struggle for Gale. One student, Fay, asserts her right to direct her own learning, thus jostling Gale's sense of autonomy as a teacher.

Eay's response to the writing assignments is to worry also, but for a different reason. Fay is insistent that her "process of learning" must come before any school-required "product of learning", that is any written assignment. Fay decides not to turn in any of the written assignments. Eay, described by her classmates as an "extreme perfectionist", explains that this all began a year ago when she felt that she "couldn't write worth her while".

The work that I would turn out simply wasn't worth the struggle and the pain and the effort to get that paper out. You have to 
immerse yourself in what you're doing to get that paper out of it... and maybe I just wasn't willing to do it... I think I just wanted to skate along the surface for a while... and feel that place.

Fay's not meeting any of the written requirements for the seminar is indicative, she says, of her approach to her other classes also.

I make a refusal to do...written work. I'm the one who pays for it...because I'm the one who either doesn't get the grade or goes nuts toward deadlines just to get things done.

To "feel the place" is Fay's priority. She says that she is now doing written work assigned by professors over a year ago! But she adds, that she is enjoying doing those "old" papers because now the time is right.

By the end of the Women and Representation seminar Fay is wondering whether she should go back and "madly put together a portfolio", which she thinks she probably will do. Though Fay has learned that "there's security in following their [teachers'] schedule where you don't have to be so controversially caught in it..."; she decides to go with it and has no regrets. She has taken the responsibility for her actions. When I ask her how Gale is dealing with the issue, she replies,

Well, I took it away from her... I said, I'll think of something else...either I'll take the bad grade or you know... I'll do something... I don't know....

For Fay, an English major, writing is something personal, something worth giving time to, when one is ready to do so, 
not when the university timetable says "your paper is due!" Unwilling to do course assignments on schedule, she takes her stand--she knows what the consequences will be but feels empowered to set her own schedule, and refuses to "play school" and "produce".

Gale's response to Fay is uncertain; nothing is said regarding the issue throughout the semester. On one writing workshop day Fay comes to class without a paper to share. Gale reacts harshly, reminding her of the requirements. Eay never returns to any of the three final classes. No one knows how the issue was eventually resolved. Mary is bothered by Gale's reaction to Fay and feels that a public statement was unnecessary. Gale should understand, says Mary, that Fay is not avoiding the work, it's just that she's a perfectionist. Mary is somewhat critical of Gale's lack of understanding of Fay's approach to her assignments.

However, Gale's role is somewhat jeopardized by Fay's insistence to do things her way. What is Gale to do? Gale recalls the times when she submitted late papers as a student, "I can hardly become a professor who penalizes students for late papers, can I?", she shares jokingly with the students. Gale may be negotiating the person-teacher boundary. Gale admits to finding the transition from "graduate assistant" to "assistant professor" a very difficult and uncomfortable one. Gale's attempts to negotiate the teacher-person boundary may be part of her 
search for autonomy as an academic. Her negotiation of this boundary is further reflected in Fay's story retold during an interview. Fay was walking across campus when she sees Gale in the distance,

She was coming down the sidewalk toward me and she was holding her husband's or her lover's hand and she was walking along swinging his hand and then she saw me and I had already seen her so I was looking the other way... and she dropped his hand and then she came near me very collected... I liked that.

Fay's commentary on this event is rather insightful; she continues, "It's always an interesting boundary to negotiate--as the instructor and as the person," where "there's a lot of hesitation and insecurities..." Fay liked seeing Gale in a "human-posture", the person had at last come out from behind the academic role.

Rose has difficulty seeing Gale as a "person". She explains that she thinks of Gale "as a teacher" which she contrasts to seeing her as a person, "Some of them (teachers) I see as people." Rose attributes her feelings toward Gale to the teaching approach, "The way that she teaches makes me think of her more as a teacher...." Rose concludes her comments by expressing a belief that it is important for students to know each other and the teacher a little better, "I think maybe in this kind of class, it would be important... you could get to know her a little bit better. 
I guess they [teachers] are more like real people when you know about their personal life."

\title{
Vulnerability and the Institution
}

Gale sees her role as an academic feminist within the institution as a transformative, epistemological one.

\begin{abstract}
The academic task of Women's Studies is to understand difference and reconstitute an academic discipline grounded on another: notion of difference...than the other disciplines. That's where I see myself, trying to reconstitute a rhetoric of difference or a narrative of difference because Women's Studies has to tolerate differences. I mean we can't tolerate heterosexist biases in our classes or sexist biases and all sorts of biases.
\end{abstract}

Gale continues,

In general I'd say that the agenda is to help facilitate curriculum reform in the disciplines, to get the disciplines to incorporate notions of gender and race and to open up the epistemological issues.... And that's really hard, that's a very hard thing to do but I think it is the job of academic feminism. It's the activism of academic feminism. So I feel it's like where my research, and my scholarship and my publications addresses those things.

Early on Gale realizes just how "hard" it is to function within the university as an academic feminist. Continuing in her search for a place where she can feel a sense of autonomy, she feels instead that she can "come onto a battlefield". 
Gale's unease with the university begins with her very appointment. Gale is confronted with a problem in terms of her feminist scholarship and the possibility of eventual tenure. Gale tells her story,

In the Humanities Center they were opposed to my position of having a feminist scholar in the Humanities... and they were instructed to continue with the search. It was before there was an issue with the position. The provost, the former provost, required the Humanities to have Women's Studies as a joint appointment. I didn't understand that there was this opposition to this position until I came here.... Then Women's Studies pulled out of the Humanities, leaving all those people who were violently opposed to the position in the first place. So I feel like whoever walked into that situation was just doomed.

Gale has been treated poorly from the start but the situation gets even worse. She finds that the Humanities have control over her tenure decision. This was not part of her contract, and she feels that there has been a breach of promise.

I was told that my tenure... that the Humanities Center would only have input about my teaching at the time of tenure. Meanwhile the Humanities director decided not to go with this. He's enjoying wielding his power, just as he's very free to do it. They could turn me down for tenure very easily.

... Before you have tenure they can real.ly decide whether your scholarship is acceptable or not. And so...but it'd quite hard to take those risks.

Gale is committed to post-structuralist theory as a highly useful contemporary way of knowing. However, by adopting post-structuralism as the theoretical framework for her research and scholarship, she has allocated herself to 
the margins of mainstream literary study. In the university in which Gale finds herself, there is not much interest shown in post-structuralism; in fact, Gale feels that faculty are actually hostile toward it. Because of her adherence to this theory she feels that she is fighting a battle.

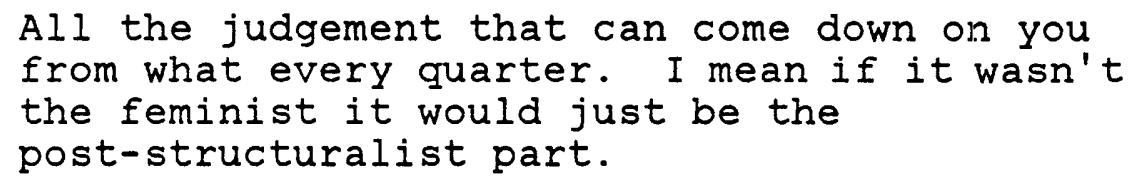

Gale does not see any openness or willingness to learn about the theory which she thinks is extremely useful. Due to the lack of sympathy for feminist, and post-structuralist, scholarship within the Humanities, Gale fears that her work would not count in a tenure decision. Therefore, to stay on at this university would be a great risk for Gale, unless she decides to return to mainstream Renaissance scholarship.

Gale feels that from the outset her position was a vulnerable one: "I feel battered at this university a lot", she shares during an interview. She has lived with the situation for two years but now has makes a decision to leave and take up a position at another university. Gale feels that there are probably some things that she could do to alleviate the situation but she doesn't feel encouraged to do so.

I could spend a lot of time thinking how I could have been different. . what I could have done to make them happy but it's really.... They [Humanities faculty] didn't introduce me to anyone.... 
Gale decides not to involve the Women's Studies Program with her struggle.

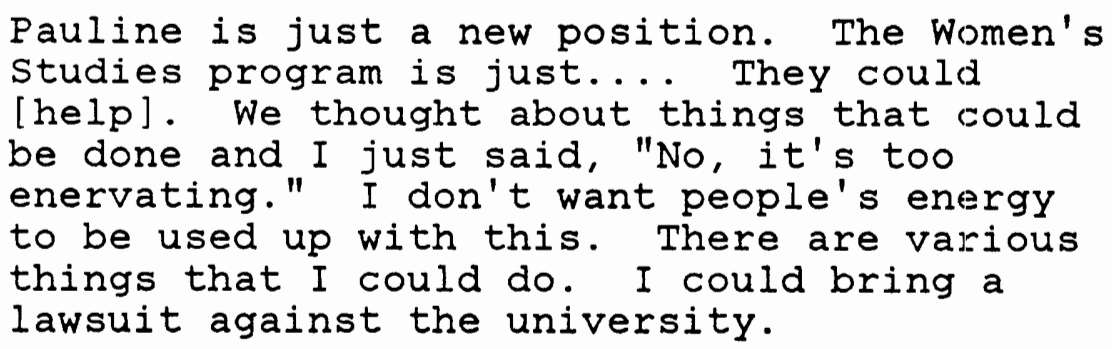

However, this is not an option that she is willing to consider.
... I hope very much that I get another job. I've applied very seriously and I think that there's a wider world and this has its own terrible things and I just don't feel, I just don't feel like I need to deal with them. And I don't want to, so I'll go somewhere else.

Gale applies for a number of jobs and is successful. She decides to leave the university for a position elsewhere, feeling that to leave academia altogether is, ...not a decision I could make, and I think that there's problems with it too. I think that people just have to protect themselves and live their lives the way that they can.

Gale's struggles are important in that they highlight the difficulty in operating as a radical teacher on the terms of one's own expertise within the institution. As a woman she looked to the institution as a public realm where personal and professional autonomy could be sought and found, a place where she could be a leader. Instead, she finds that she must struggle constantly to attain and maintain that sense of autonomy as a teacher and as a scholar. Is it the particular 
institution in which Gale finds herself that is problematic? Or is there always a struggle for autonomy for the radical academic woman? 


\section{CHAPTER 3}

\section{FINDINGS}

\section{Introduction}

The objective of this study has been to inform the concept of the teacher as a "transformative intellectual" by juxtapositioning a critical theory with feminist practice. I have found that the notion of teacher as transformative intellectual is incomplete and problematic.

The major findings of the study revolve around four dimensions of the concept of "transformative intellectual". First, I will suggest that the notion of transformative intellectual relies too heavily on abstract, and highly rationalistic, constructions of "experience", "empowerment" and "dialogue" as transformative strategies. Second, the transformative intellectual is complicit in the production and legitimation of certain kinds of knowledges, in the context of pedagogy as an "interactive productivity". Third, "transformative" may not refer to a state, or characteristic, of an individual but rather to a relationship between individuals in a group. Einally, the study points to the immense difficulties posed by the university institution to the work of the would-be transformative intellectual. I will proceed to explore each problem in turn. 


\section{Key Constructs: Experience, Empowerment and Dialogue}

Giroux and McLaren's (1986) vision of democratic schooling depicts the teacher as a transformative intellectual engaged in empowering students by focusing critical dialogue around the topic of student experience. This study has underscored the rationalist assumptions undergirding all three constructs--experience, empowerment, dialogue--guiding the radical teacher's activity.

By rationalist assumptions I mean the notion that there is one correct interpretation of a situation, which students can arrive at by use of critical thinking skills. The single interpretation should then facilitate a single conclusion regarding the action necessary to improve or change that situation.

Ellesworth (1989) notes that rationalist assumptions of critical pedagogy have led to such goals as,

of analytic and critical skills for judging the truth and merit of propositions, and the interrogation and selective appropriation of potentially transformative moments in the dominant culture.

$$
\text { (Ellesworth, 1989, p. 303) }
$$

The transformative intellectual is, in this sense, someone who enforces rules of reason in the classroom. Ellesworth (1989) defines rules of reason as "a series of rules of 
thought that any ideal rational person might adopt if his/her purpose was to achieve propositions of universal validity". The universally valid proposition is namely that "all people have a right to freedom from oppression" (Ellesworth, 1989). The critical literature (feminist studies, cultural studies) has at this point provided enough evidence of the extent "to which the myths of the ideal rational person and the "universality" of propositions have been oppressive to those who are not European, white, male, middle class, Christian, able-bodied, thin, and heterosexual", according to Ellesworth (1989, p. 304). Following Ellesworth, I reject the notion of "rationality", as defined here, as undesirable. Moreover, in the context of the liberatory Women's Studies classroom "rationality" as a goal is highly inappropriate.

\section{Experience}

Giroux and McLaren (1986) emphasize the primacy of student experience in the emancipatory project. These writers propose to take "the problems and needs of the students themselves as [the] starting point" of the emancipatory project. The transformative intellectual tries to understand, affirm, and analyze student experience in order to devise consciousness raising strategies.

For students in the Introduction to Women's Studies course, sharing experience meant sharing personal stories. Mackinnon (1988) underscores the necessity for women of 
talking and writing about their personal lives as a means to understanding the politics of their situation as women. Women's identities have been constituted in terms of a female sexuality defined in terms of men's needs. By means of consciousness raising, according to Mackinnon (1988), women can begin to understand "the collective reality of women's condition from within the perspective of their experience, not from outside it." When course participants tell stories of and from their lives, or the lives of others, they participate in a process of endowing those experiences with meaning; that is, they make some sense of the complexity for now.

"When a woman tells the truth she is creating the possibility for more truth around her", writes Rich (1979). Women have a profound stake in describing reality as honestly and openly as they can. Speaking publicly about experiences of incest, rape, menstruation or lesbianism, is itself a radical departure for women who have been restricted to a discourse of the hidden and private. The purpose of women's speech is survival, expansion of women's own understanding of their oppression and strength, sharing common experiences among women, building solidarity among women, and political strategizing (Ellesworth, 1989, p. 312). It is the difference between living your life as a subject who constitutes your own identity and living as an object constituted by the needs and desires of others. 
To speak in narrative frames may be to speak in "nonrational" tones. It is to ground speech in a different kind of rationality [than that implicit in the consciousness raising efforts of Giroux and McLaren], and hence, to redefine the foundation for transformative classroom interaction. Narratives of experience told in Introduction to Women's Studies were not bound to the rules of reason; neither did they contain "universally valid propositions". Muireann's stories, specifically, were partial, bound to the emotional, the personal, and the local. The teacher and students, as women, were in their experiences; "instances of suffering" were their own. With such stories there can be no rational detachment,

the emotional life, from the particularities of time and place, from personal quirks, prejudices and interests, and most certainly from the object itself.

(Bordo, 1988)

When students and teacher talk to one another about their experience they reveal multiple perspectives on a collective condition--an experience of oppression due to gender. The very realization of multiperspectivity reveals "aperspectivity" as a highly "rational" strategy of male hegemony (Mackinnon, 1988), and encourages a critique of such hegemony. As Simone de Beauvoir expresses it,

Representation of the world, like the world itself, is the work of men; they describe it from their own point of view, which they confuse with the truth. 
Narratives of experience as critical pedagogy call for a new form of critique, a different notion of critical

thinking. Traditional conceptions of critical thinking inherent in the critical literature propose that students and teacher seek to develop "impartiality" so as to grasp the perspective of others. The centrality and force of reasons must be upheld at all times (Siegel, 1988). To trust reason as the only way to understand another's perspective is to revert to questioning and doubting the other's beliefs. The process of the believing game as given to us by Elbow (1986) involves a radically different kind of understanding; one which trusts another individual to participate in a joint construction of experience in the telling. Belenky et al; (1988) write that,

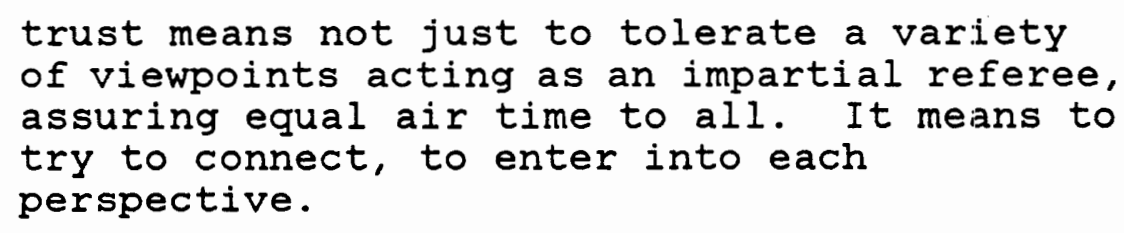

(Belenky et al; 1988, p.226)

The believing game in this sense does not refer to evidential belief with "truth" the only goal in sight. There is not just ONE story. There are many stories to be told, many experiences to be shared. The tensions, ambivalences, contradictions between stories, and within them, are not always bad. Rather than force a false closure course participants can cultivate these contraries dialectically for further meaning. 


\section{Empowerment}

The problem of an over-reliance on rationalism reappears as I consider the assertion that the transformative intellectual empowers students. The strategy of empowerment give the illusion of equality while in fact leaving the authoritarian nature of teacher-student relationship intact.

The notion of empowerment in the case of Gale reflects the critical notion that by teaching analytic and critical skills to students teachers can ensure interrogation of oppressive nature of dominant culture. Simon (1988) sees the importance of empowering students "through the development of the practical competence inherent in theorizing". Gale's attempts to teach her students post-structuralist theory reflects a similar belief--that theory has the power to illuminate and uncover ideology and, as such, empowers students by giving them a tool for the practice of critiquing western representations of women in art and literature.

However, as we have seen in Case 3, the proposed process of empowerment can have results opposite to its author's intentions. Theory in the Women and Representation seminar becomes a master discourse which students find oppressive. Students find themselves participating within the confines of a traditional academic model. Pat Mahony (1988) writes about an academic model that "rests on the notion that there 
are experts whose job it is to initiate students (who are ignorant) into the mysteries of their subject" (p.104). Mahony's description is reminiscent of Paulo Friere's banking concept of education which stresses "knowledge as gift to be bestowed" by a narrating subject (the teacher) and patient listening objects (the students) in an act of depositing information (Eriere, 1972 p. 46). In an effort to empower students Gale finds that her students feel disempowered. Learning and teaching to theorize becomes a paternalistic activity which ultimately reasserts teacher authority and power over students.

In their attempts to deal with the issue of power in the classroom, Giroux and McLaren (1986) introduce the notion of "emancipatory authority". By emancipatory authority critical theorists mean that the teacher acknowledges authoritarianism of education as inevitable and tolerable depending on the situation. So, for example, imbalances in the teacher-student relationship are permissible in the context of "sharing information, promoting open and informed discussion, and maintaining itself [authority] only through the respect and trust of those who grant the authority" (Shor \& Eriere, 1987, p.22). However, Shor and Eriere's position on authority may place too much trust in a teacher's ability to free her/himself from his/her power over others. Chloe who is highly aware of the knowledge-power nexus but she feels that she needs to "convey information" to her students. 
The students feel "talked down to", and resent Chloe's assumption of their inability to interpret the text for themselves. Chloe wants to explicate the text to promote informed discussion; but students see her acting as an authority figure imposing a certain version of the truth on them. Although teachers encourage students to share different viewpoints--a plurality of moral and political positions--they should be aware that the teacher's own assessment of issues does not get equal weight with those of students--in fact, the institutional role as professor always weighs teacher's statements differently (Ellesworth, 1989).

There is a final aspect of "empowerment" that becomes problematic in light of this study. Critical theorists neglect the question: how do the disempowered empower? Gale, as a new, untenured college professor, in a department that doesn't appreciate feminist scholarship, is vulnerable to censure by her male colleagues because of her feminist views. In such an academic environment Gale may feel disempowered, and hence, find it difficult to empower her students in turn. Muireann is another radical teacher who is negotiating a sense of public, institutional authority with a more uncertain sense of self. Muireann's view of the world is less certain, "more amorphous" than some of her feminist colleagues. Muireann's uncertain sense of self is transferred to the classroom as a tentativeness, an unwillingness to assert her institutional authority--"I can't 
go in and say, "This is the way it is" and sometimes I think that's a weakness", she tells me. Muireann refers to a "constant struggling against the conditions of her work" and an uncertain sense of self as a feminist. Both Muireann and Gale move us to question the concept of transformative intellectual as an immutable, certain, empowered individual. I find instead that these radical teachers are actually vulnerable human beings.

\section{Dialogue}

Transformative intellectuals supposedly engage their students in discussion and deliberation on oppression in our culture. There aim is to arrive, with the students, at some unified perspective on the action necessary to overcome that oppression--this process is described in the critical literature as "dialogue".

Once again we run headlong into rational notions of synthesis and closure in the form of a "unified voice", eliminating multiple perspectives and differences among group participants under the rubric of the "best answer/action". The criterion for judging "best action" is that it should represent an effort to improve the quality of human life. The "quality of human life" or "best action" according to whom? To say that dialogue will lead to one, unique answer to these questions does violence to difference. 
Ellesworth (1989) writes that "dialogue", in the critical literature (Giroux and McLaren), consists of ground rules for classroom interaction using language.

These rules include the assumptions that all members have equal opportunity to speak, all members respect other members' rights to speak and feel safe to speak, and all ideas are tolerated and subjugated to rational critical assessment against fundamental judgements and moral principles.

(Ellesworth, 1989)

In light of my exploration of three "liberatory" classrooms I suggest that problems arise in the application of these ground rules. There is a problem of students' and teacher's asymmetrical positions of difference and privilege. The "us" and "them" may not simply be the nebulous "oppressor" outside the classroom against the more enlightened individuals within; rather oppressor and oppressed can co-exist within the classroom context as student-teacher or as student-student. Chloe's case represents such difference. Kelly's retort "I am not you" is a powerful statement of such difference referring as it does to the teacher's authority and political position; ultimately both sources of power must be reckoned with by the transformative intellectual.

To strive for agreement or "sameness" in position and perception of participants may in fact stifle the possibilities in dialogue of identifying moments of oppression and suffering. Witness the Lesley-Don exchange 
in Case 2. Don, a white male student, advocates speaking out and not being afraid to speak openly in the classroom context of Feminist Theory 3000 and beyond. Lesley retorts defiantly that she is a lesbian and when lesbians speak out they get beaten up, even killed. She tells him in emotional and emphatic tones--"I am afraid, I am afraid. Find a place where you have been hurt and then you might begin to understand." There are perhaps a number of lessons about "dialogue" to be learned from this exchange.

First, to assume unproblematically that all students are united in their quest of understanding and overcoming oppression is highly problematic; it ignores the presence of oppressor and oppressed, subordinator and subordinated in the classroom context. Lesley and Don are unable to speak from a unified standpoint; their subject positions and personal investments therein are vastly different.

Second, Lesley's speech may exemplify what Bell Hook's (1984) calls "talking back". Lesley is not simply sharing her experience of lesbianism with Don so that he might understand it. Instead, her defiant speech challenges, and perhaps rejects, the privileged position that Don can afford to take, privilege that she as a member of a subordinate, oppositional group cannot have. The notion of "talking back" raises the issue of risk and the safety of silence in the transformative classroom. 
Third, these issues of "risk, trust, and operations of fear and desire" that surround the questions of identity (and politics) in the classroom must be considered. In case 1 , Marian, a lesbian, is distanced by her classmates as the "irrational" other. Marian's expression of frustration and anger communicated the story of her lesbian experience at an allegorical level. "What got said-and how-was the product of highly complex strategizing for the visibility that speech gives without giving up the safety of silence" (Ellesworth, 1989). Marian never tells her story explicitly and as such she participates in a highly complex negotiation of the politics of knowing and being known (Ellesworth, 1989). Things are left unsaid, or they are encoded, on the basis of Marian's conscious or unconscious assessment of the risks and costs of disclosing her experience and understanding of that experience completely. Heterosexual students, for the most part, remained silent that day in Introduction to Women's studies class. These students, in socially constructed positions of privilege, didn't risk being known by Marian in the same way that she didn't risk being known fully by them. Ellesworth (1989) asks, "To what extent do silent students during an exchange [of this kind] relinquish the security and privilege of being the knower?"

Dialogue may be too "rationalist" a "tool" to loosen the "deep-seated, self-interested investments in unjust relations" of, for example, sexual orientation and other 
personal choices. It may be useful, for critical theorists and transformative intellectuals, to render the classroom as "text" whose power relations students and teacher can examine and deconstruct, toward the end of a more refined understanding of the fragmentary nature of any "unity" or "solidarity" among a group of individuals--as such "unity" is never a given but something constantly demanding of effort on all parts. Ellesworth (1989) cites Biddy Martin and Chandra Mohanty who envision another form of "dialogue" based on a notion of "unity" or "collectivity" as fragmentary.

They envision collective struggle that starts from an acknowledgement that "unity"--interpersonal, personal, and political--is necessarily fragmentary, unstable not given, but chosen and struggled for--but not on the basis of "sameness".

$$
\text { (Ellesworth, 1989, p. 315) }
$$

\section{Knowledge Construction and Transformative Pedagogy}

An issue which deserves closer attention by critical theorists, in their presentation of teacher as "transformative intellectual", is the role played by the intellectual in the production and legitimation of certain kinds of knowledge in the context of pedagogy.

Pedagogical practices specify "a particular version of what knowledge is of most worth,... what it means to know something, and how we might construct representations of 
ourselves, others and our physical and social environment" (Giroux \& Simon, 1988). Therefore, to propose a type of pedagogy is to produce and legitimate certain kinds of knowledge and ultimately to construct a certain kind of political vision. The question then is what kind of knowledge does the transformative intellectual help to produce and validate.

I have been exploring Women's Studies classrooms. The feminist literature suggests that feminist pedagogues are involved in, and involving their students in, a critical conversation which, by its form and content, attempts to deconstruct and reconstruct knowledge-making as it is validated in western industrial societies. The project is one of demystification/consciousness raising in which students and teachers reflect not only on what they have come to know, but also on the way they have come to know. In practice, however, the pedagogical process may produce forms of knowledge and knowledge-making not considered consciously by feminist teachers. Pedagogy then becomes less and less the application of theory and more and more an act of construction... and whose knowledge is being made, and validated, in feminist classrooms?

In the following sections, I am conceptualizing knowledge both as "process" and "product". Knowledge as process refers to "ways of knowing" or how an individual comes to know. Knowledge as product refers to the end result of such 
process, a more "static" conception of knowledge. Both conceptualizations are relevant to the present study. I will explore knowledge as "product" as it emerges in Cases 2 and 3 , and knowledge as "process" as it is played out in Case 1.

Knowledge as Process: Experience as a Way of Knowing

In Introduction to Women's Studies, experience as a way of knowing is validated; the history and experience of students becomes central--the "stuff of culture, agency and identity formation" (Giroux, 1986). Experience becomes text to be interpreted, analyzed and understood in new or different terms; it is gendered, and as such can be reconstructed in political terms. Experience as a social phenomenon becomes part of a process of empowerment and self-definition.

Bruner (1986) suggests that stories or narratives initiate performances of meaning. The story is told and thus begins and guides "a search for meanings among a spectrum of possible meanings"; stories do not formulate, singular meanings, singular interpretations. In Introduction to Women's Studies, class participants' initial understandings of another's story of experience, through the juxtapositioning of their stories with others, develop until they have a new story, not a synthetic production that collapses two stories into one but rather a new story, with a "life" of its own. They have constructed a new story of 
their experience in a social context. Students tell stories from experience using their learned frameworks of interpretation. Muireann stories are always set within a feminist frame. Juxtapositioning personal frames with feminist frames may lead to students changing their interpretations of their experiences; but then again it may not. Experience then operates as a democratic way of knowing .

The pedagogical process of Introduction to Women's Studies reflects what Belenky et al; (1988) term "connected knowing". The pedagogy of experience sets up personal experience as "the most trustworthy knowledge" rather than pronouncements of "fact" from the teacher. Muireann announces at the beginning of the semester, "I can't make pronouncements. I won't make pronouncements". In this sense, the "truth" is presented and accepted by Muireann as personal, particular, and grounded in first hand or vicarious experience. As a way of knowing, experience frees individuals from the fiction of knowledge as truth, and empowers them to participate in the construction of selves and their realities. Moreover, experiences a way of knowing, in Muireann's sense, is richly affective; experience is "felt" (Connelly, 1990).

Experience as a way of knowing introduces a series of dilemmas to the transformative intellectual, however. Diane Fuss (1990) points out that there is a tendency "to 
psychologize and to personalize questions of oppression, at the expense of strong materialist analyses of the structural and institutional bases of exploitation." Call to mind Kelly in Case 2, where Kelly attributes her feeling of being silenced, or censored, by Chloe, the teacher, as a personal problem--Kelly decides that as the semester progresses she will feel more comfortable. Kelly steps back from an analysis of the authority-power dynamic existing between herself and her teacher; fortunately the analysis is subsequently provided by Chloe.

A second dilemma of experience as a way of knowing, according to Fuss (1990), is that we may delude ourselves into thinking that "experience" is a "reliable guide into the real", the pure--free from the pervasive influence of ideology. However, if experience is viewed as a product of ideology then it can function as a window into the complicated workings of ideology. Fuss writes that

Experience would itself then become "evidence" of a sort for the productions of ideology, but evidence which is obviously constructed....

Muireann's persistent attempts to raise students' awareness regarding the issue of rape is an example of the use of experience as evidence of ideology. In validating experience as a way of knowing Muireann legitimates knowledge as a process of construction, theory-laiden and arbitrary. 
Knowledge as Product: Dilemmas of Knowing

To structure this discussion I draw on Ginsburg's (1989) notions of knowledge as "molecular or holistic" and "given or problematic".

The distinction between "molecular and holistic knowledge contrasts knowledge as "fragmented or strongly bounded and having clearly distinquished content areas (molecular), with a view of knowledge as "integrated or having weak boundaries separating subjects or topics within subjects (holistic) (Ginsburg, 1989, p. 12). The syllabus of Feminist Theory 3000 reflects the teacher's interdisciplinary approach to knowledge and foreshadows the production of a specific kind of knowledge through pedagogical processes--a knowledge that is holistic.

Chloe's approach to course content is an interdisciplinary one. The syllabus of Feminist Theory 3000 testifies to the centrality of "themes" [rather than disciplines] as basic organizing categories. Disciplines, and specialized areas of knowledge within disciplines, contribute to a deeper understanding of class participants. For example, the theme of female sexuality is introduced by a reading of a review of Adrienne Rich's essay, entitled, "On Compulsory Heterosexuality: Defining the Issues", together with Clarke's essay, "Lesbianism: An Act of Resistance". The articles help raise questions like: "what happens when we ask why people become heterosexual, not why they become 
homosexual?" Tentative answers to these questions are presented by students of Psychology, Human Development and Philosophy.

Riane Eisler's book, "The Chalice and the Blade," sets the scene for much discussion on masculine and feminine modes of being, their respective connections to violence and peace, and the way the categories of "male" and "female" have acted as forces in shaping human culture. During class discussions disciplines of Anthropology, History, Archeology and Religion are drawn upon.

Feminist inquiry constitutes a "rethinking of history". The course-Feminist Theory 3000-explores a number of writings by feminist historians who place the category of woman at the center of their work. A body of work by Elaine Pagels on the Gnostic gospels, "What became of God the Mother?" focuses on issues of "interpretation and power within cultures over time, in the Western World. Whereas Pagels is concerned with constructions of "feminine gods"--goddesses in Biblical terms, Carol Smith- Rosenberg in her work, "The Female World of Love and Ritual" presents relations between women in nineteenth century America in new/different light. Smith-Rosenbery's work leads a discussion on women's friendship, lesbian relationships, dependency models of relationships involving women.

Students came from various disciplines with a conception of knowledge as a static, fixed possession. In the context 
of Feminist Theory 3000 there appeared to be no "fixed" object or body of knowledge, only themes which drew on their disciplinary knowledge bases and yet required no one, not even the teacher, to be expert. Knowledge that is presented without rigid boundaries perpetuates notions of knowledge as holistic and integrated. As students view knowledge in a different light, disciplinary knowledge begins to look arbitrary and constructed in its form. The object of Chloe's course was to explicitly communicate the constructed nature of knowledge in its disciplinary form. Her pedagogical approach conveyed this at an allegorical level by relying on the disciplines to contribute, rather than constitute, the course structure.

The distinction between knowledge as " "given or " "problematic"" contrasts knowledge as "objective, absolute and uncontroversial" with a view of knowledge as "constructed, provisional, tentative, subject to political, cultural and social influences" (Ginsburg, 1989). Implicit in this distinction is the issue of what role the teacher plays in conceptualising, designing, and implementing a curriculum. In Case 3, Gale is seen to take curriculum knowledge as given as she struggles to learn and teach post-structuralist theory. There is little time spent rendering such knowledge problematic and most time spend grappling with it as a fixed object to be understood. students become intimidated by the "knowledge" and perceive 
a "right answerism". Knowledge as a performance where teacher becomes the transmitter or deliverer of knowledge, is legitmated on the one hand. Yet students are aware of the oppressive nature of such knowledge and present a silent resistance.

In Case 2 we saw a similar presentation of knowledge as "given", as the teacher provides interpretation after interpretation of different texts. Moreover, knowledge seems to be unitary in that there is a "best fit" interpretation--a feminist one belonging to the teacher. However, the presence of the affinity group and their role in classroom pedagogy seems to speak to knowledge as the product of a linguistic community who have learned to see the same things when confronted by different stimuli. It becomes clear to students that members of the affinity group share commonality with Chloe and seem to hold a similar point of view in terms of feminism.

Notions of knowledge as "given" may perpetuate relations of domination and an unequal distribution of power. The object of discourse might be conceptualized, in this instance, as a "power-saturated" discourse that monitors and normalizes students sense of who they are and what is possible. 


\section{Transformation as a Social Act}

Being a transformative intellectual is not a state, or characteristic, of an individual; it is a social relationship that has to be constantly constructed and maintained. To see the transformative project embodied in a single individual teacher is repressive of teachers and students, but also limiting of possibilities of transformation.

Inherent in the concept of transformative intellectual is a notion of the teacher as a central figure in the process of consciousness raising. The transformative intellectual is viewed as the origin of what can be known and done in terms of the transformative project.

There is an implied superiority of the teacher's understanding--what might be termed "true consciousness" and the process by which $s /$ he brings students to this "place". Critical theorists, Giroux \& McLaren (1986), assign a three-fold task to the transformative intellectual: 1) $\mathrm{s} / \mathrm{he}$ must be "attentive to the histories, dreams and experiences" that students bring to class, in order to lead students beyond their initial, "naive" interpretations of experience to a more "critical" perception of it. The teacher is supposed to play a key role in bringing to light" subjugated histories, experiences, stories and accounts of the oppressed. 2) Giroux and McLaren (1986) say that the must be a "bearer of dangerous memory" who can "point to the 
histories of women, blacks, working-class groups, and others whose histories challenge the moral legitimacy of the structures of society and therefore contain knowledge too "dangerous" to make visible". 3) Finally, according to Giroux (1986), the teacher's task is one of clarification, of impressing upon individuals that they are "called to struggle, to imagine new political alternatives and convince others of the need to appropriate "buried knowledge" in the interest of constructing more democratic societies." In Chapter One I quote Pattie Lather's summary of the "duties" of the transformative intellectual as follows:

The role of the intellectual is to develop the progressive forces of present history to become conscious of themselves, to transcend economist and privatized concerns, to aspire toward a substantive democracy, and to begin to see how social transformation can be accomplished.

$$
\text { (Lather, 1983: 40) }
$$

If Giroux's role description for the transformative intellectual is sincere, then he might be accused of presenting the transformative intellectual as a mythical figure struggling all alone against the world! Nietzsche's (1969) commentary on the intellectual comes to mind ...the isolated struggling, heroic,
oppositional figure rising above the
treacheries of past and present. (Nietzsche, 1969)

Critical theorists may be guilty of essentializing the concept of transformative intellectual as the "all-knowing" 
individual who "is beyond racism, sexism and all other oppressions (Gore, 1990).

A critical theory of the teacher as transformative intellectual who empowers students in a democratic classroom context, may lead us to think of the teacher as some kind of "lamplighter". Shor and Eriere (1987) express it as follows:

The teacher walks into the classroom, provokes some illumination, like turning on a light switch and then walks out mission accomplished.

(Shor \& Eriere, 1987, p. 21.).

Shor and Friere (1987) point out that to conceptualize empowerment as a process of lamplighting suggests that the teacher can interact with students as individuals, manipulating and directing their consciousness of their individual experience, in order to raise that individual's consciousness to appreciate its ideological dimensions. In this sense, the critical pedagogy of the transformative intellectual is a practice through which students "are incited to acquire a particular moral character" (Giroux \& Simon, 1987).

There is a tension, it seems, between "informing consciousness of the next generation" (Chapter one) and "imposing a regime or politics of truth" on it. Foucault (1980) describes the notion of "regime of truth" as follows, Types of discourse which we accept and make function as true; the mechanisms and instances which enable us to distinguish true and false statements, the means by which we 
sanction each; the techniques and procedures that we accord value in the acquisition of truth; and the status of those who we charge with saying what counts as true.

(Eoucault, 1980)

If we give the transformative intellectual the power to decide what is true and false in terms of valid knowledge, and in terms of the methods we use to gain such knowledge, then we also give her/him to power to dominate. As Foucault (1980) points out, it may not be a question of who informs consciousness but rather who will determine what counts as knowledge. The transformative project can become a dominant or totalizing discourse.

The foregoing scenario is not difficult to imagine in light of this study. Academic feminist, Chloe, in her struggle with the knowledge-power nexus or linkage, may really be struggling against "the temptation to impose a feminist orthodoxy that students do not feel free to critique" (Friedman, 1985). Chloe's inner conversation may be helpful in that it represents a "self-styling" or selfdisciplining on the part of the radical teacher in the construction of classroom discourse (Gore, 1990).

To rely on the inner conversation of the transformative intellectual may point us to the importance of "conversation" per se. Positing the teacher as central to the radical project is to deny the importance of community--the social context of transformation. Reflection is an important 
element of the process of raising consciousness. Reflection in its democratic sense is interactive in that it values and explores many kinds of meanings [ the "fragmentary unity" of dialogue]. In the classroom context reflection calls for a type of interaction that values the meanings of all participants. A community of individuals who exchange ideas and viewpoints open up control of the discourse and does not permit the growth of authority in one source only (for example, the teacher). The source of authority is the group and reflection in a social context represents an instance of social action (Cinnamond \& Zimpher, 1989).

In the current study the idea of a "transformative community" emerges as an interesting and powerful concept. Chloe comes close to Giroux and McLaren's (1986) idea of "bearer of dangerous knowledge"; she explicates the sufferings of women in society with stories of misogyny, incest, rape and women's silence. Yet this is inadequate for students, and apparently oppressive. Stacey comes to class seeking a "community" of knowers but instead finds a "body of knowledge". Stacey comments, "In listening to the voices of others I find my own." In the case of Muireann, we see the importance of juxtapositioning of narratives among a group, rather than between teacher and students. Major efforts are made by the teacher to facilitate a sense of community. It is through their interactions with others that students in Introduction to Women's Studies course attribute 
their "transformative moments". Sue announces that she has learned to listen to others and to refrain from being impositional with her point of view. Dawn believes that she has to appreciate diversity as she listens to the different voices of her classmates. In Case 3, it is through a feeling of solidarity that develops outside the classroom that the students feel empowered to participate in class discussion, and "not just sit there".

Students across all three cases sought to build connections with each other. As Shrewsbury (1987) points out these relationships are more than a set of interactions among people--they are a web of existence. Gilligan (1986) states that it may be that students are defining themselves in terms of their connection to one another. They do not act as "individuals", nor do they wish to image their teacher and classmates as such; rather then see learning, their process of empowerment as a social responsibility.

The notion of the all-powerful transformative intellectual is reminiscent of such pieties as "the keeper of the free world". Maxine Greene (1989) posits the question: "How much does the possibility of freedom deepen on critical reflectiveness, on self-understanding on being with others in a caring relationship?" (p.79) Shrewsbury (1987) answers Greene's question when she says, "Empowerment is only possible when there is a sense of mutuality". Students in this study seem to ache for connectedness among 
one another. The existence of affinity groups in the classroom context further suggests, to my mind, the need for connection and relationship with others so that individuals can develop a sense of individual autonomy that grows out of a sense of collective experience. Students in Feminist Theory 3000 create an affinity group--Women's studies concentrators/English majors/lesbians--these women sit close by each other, they pass comments among themselves during class, they are of a similar standpoint in terms of their commitment to feminism. Rather than view the existence of this group as a threat to accomplishing unity in dialogue, which some other students do, the affinity group may actually further attempts at dialogue in that they provide some students with "safer home bases" from which they gain support, important understandings and a language for entering larger classroom communications/interactions. In Case 2, Penny and Joan express feelings of being "outside" the group; they wish to change this situation but don't know where to begin. Ultimately, Penny decides not to attend class. Once more students appear to prioritize and value community-membership.

The concept of transformative intellectual is too individualistic in its neglect of solidarity among groups of students or among teacher and students. If critical theorists continue to posit the transformative project as resting on the shoulders of one individual they may be in 
danger of creating new myths that are imposed rather than a social critical perception of lived experiences.

\section{Transformative Intellectual and the Academy}

Giroux and McLaren (1986), drawing on the work of Gramsci, Foucault and Lenntrichia, assert that the

..the intellectual is one whose radical work

of transformation, whose fight against

oppression is carried on at the specific

institutional site where $s /$ he finds

her/himself on the terms of her/his own

expertise, and on the terms inherent to

her/his own functioning as an intellectual.

This study presents a challenge to this "critical" assertion.

Before exploring this challenge I will first present some issues pertaining to women as transformative intellectuals in the university context as they have emerged in this research.

For many women in academe there is a constant debate and struggle between the "roles" of "nurturing mother" and "truth-saying father". In western culture, "the roles of nurturer and intellectual have been separated not just by gender, but by function, to try to combine them is to create confusion" (Cully et al; 1985).

Neither one's mother not one's therapist has to grade one's dreams or one's toilet training, or make sure that one understands Wollstonecraft's philosophy and Engel's....

$$
\text { (Cully et al; 1985, p. 13) }
$$


Women are expected to nurture and as professionals to compete, and nurture competition in students. They become in Anne Halley's terms "the bearded mother" for their students. Our very presence in the university as "women thinking" or the "female authority" is highly paradoxical (Cully et al; 1985).

Yet the paradox is underscored further as academic women declare themselves academic feminists and enter an arena of the "heavily bearded mother"! "The female intellectual appropriates the word for herself and its power to name the manifestations of patriarchy". (Cully et al; 1985, p.18). Previously, the presence of women as female intellectuals may have begun to alter the construction of gender as it is conceived socially; now the alterations are intentional and deliberate as they seek to systematically demystify the production and distribution of knowledge, and raise the consciousness of our students regarding the current epochal theme (Eriere, 1979) of patriarchal domination.

Being who we are, doing what we do, enmeshes us (and our students) in contradictions, contradictions potentially generative of change in our educational system, perhaps even in the deepest structures of our gender arrangements.

$$
\text { (Cully et al; 1985, p. 11) }
$$

Intellectuals have a passionate or powerful commitment to academic life and work. Such commitment to being intellectuals on university terrain within the dominant 
culture conflicts with a commitment to their transformative work as radical pedagogues within the same academic universe.

On the one hand, such intellectuals earn a living within institutions that play a fundamental role in producing the dominant culture. On the other hand, they define their political terrain by offering to students forms of alternative discourse and critical social practices whose interests are often at odds with the overall hegemonic role of school and the society it supports. The paradox is not easy to resolve....

$$
\text { (Aronowitz \& Giroux, 1985) }
$$

Living with paradox and contradiction is not easy. In the present study the tension emitted from the academic feminists' positions are connected to two specific transformative agendas: scholarship and pedagogy.

\section{The Problem of Academic Scholarship}

Gale believes that there is academic freedom--after tenure. She finds that her feminist scholarship is unacceptable for tenure and promotion purposes. No administrator or member of faculty states this as fact to Gale; however, the "battle" over who will be involved in her tenure decision is really a battle around the issue of power to validate certain kinds of knowledge. If the Humanities department gain some say over Gale's tenure and promotion she will be under increased pressure to work within "malestream"/mainstream literary scholarship. Gale faces much hostility toward her feminist scholarship from 
colleagues within the Humanities. Gale decides to continue to fight her case. "It's just not worth it", she says; ultimately Gale decides to leave the university to join another, more sympathetic to her feminist interests. For Gale to carry on her radical scholarship in this particular university would be a constant struggle. There is no such thing as working on the terms of her own expertise before tenure.

Yet, even after tenure there are still immense problems for radical scholarship. Chloe "goes up" for promotion to the level of "Full Professor". She is rejected by her departmental committee on the basis of her feminist approach to literary criticism in writing and in the classroom. Her complaint is registered with the Equal Opportunities Affirmative Action office, and after six months of deliberation the university promotes Chloe. Nevertheless, Chloe decides to leave the university also.

The radical or transformative struggle demands professional costs. Audre Lordre's statement, "The master's tools will never dismantle the master's house", takes on new meaning--the master's tools will never do it because the master won't allow it.

\section{The Problem of Political Pedagogy}

The university has a very distinct culture in terms of habits of thought and social relations. Young-Breuhl (1988) 
suggests that "habits of thought" organize social relations as much as social relations organize habits of thought. With Jane Roland Martin (1986) I submit that our ways of thinking in the university espouse the development of mind, governed strictly by reason and defined as the acquisition of knowledge. Social relations within academic classrooms reflect the rational educational ideal. Distance and objectivity abide in the teacher-student relationship.

Like chamelons, transformative intellectuals cannot help but take on the color of any structure they inhabit (Belenky et al; 1988). There is much security to be had by intellectuals when they can tuck themselves into a niche within university structures. The vulnerable Gale, learning how to play the academic game, resorts to the rational academic model of knowledge transmission, maintaining distance between herself and her students. Chloe privileges the theoretical knowledge of feminism feminism--feminist theory--and falls into a distancing mode of explication and lecture, toward the end of students' knowledge acquisition. However, both academic feminists simultaneously struggle pedagogically to respect and encourage the subjective, personal voice of their students--Chloe by her own self-disclosure; Gale by encouraging students' interpretation in their writing. Muireann, by emphasizing the primacy of personal experience as a way of knowing, seems 
to stand out as someone who ignores the university and plays the academic game on her own terms.

By introducing "non-rational" modes of thought into the university transformative intellectuals are "speaking from the other side opposite to the sayings that they hear so they can create a space and a place for themselves", says Muireann.

It seems that to "speak from the other side" pedagogically is difficult; to "speak from the other side" in terms of scholarship is dangerous.

\section{Conclusion}

It may be that in being a transformative intellectual within the university the teacher sets up a kind of carnival space. Teachers construct a temporary loss of boundaries between "reason and emotion", between strict disciplinary molecules, between roles of teacher and student, subordinator and subordinate. But carnivals, historically, take place in societies that have highly structured laws, and firm hierarchial and authoritarian positions. The loss of boundaries is temporary and soon distinctions are reestablished more clearly than before.

The transformative intellectual as a carnival participant is both actor and spectator, subject of the spectacle, object of the game--she is at once "political" and "intellectual". Chloe's voices are jarring as Arthur asks, "So how radical 
can an academic be when academia is entrenched in all sorts of exclusive practices?" Olivia answers, "Maybe this doesn't belong in the college curriculum; maybe the university is far too conservative a place to pursue something like this. A lot of women have left academe for that reason. Who knows...maybe I will some day." Arthur responds, "I wouldn't know what to do if I left the academic world." 


\section{CHAPTER 4}

\section{REFLECTION ON THE RESEARCH PROCESS}

\section{Gaining Access?}

It was in the aftermath of some independent study of the new scholarship on women [Jane Roland Martin, Nell Noddings, Evelyn Eox Keller, Carol Gilligan], in the Summer of 1988, that I decided to pursue Women's Studies as the cognate area in my doctoral program. Unwittingly, I thus began the process of gaining access to the site of my later research.

I had numerous discussions with my advisor regarding my interest in feminist scholarship. Soon, it became clear to both of us that taking Women's Studies as my cognate would be a highly appropriate thing for me to do. However, "gaining access" to Women's Studies courses, all of which were undergraduate courses, meant requesting exemption from existing policies governing doctoral study. My advisor wrote a letter to the graduate school, in which she presented a rationale for our request. At that time, I approached Chloe, the interim coordinator of the Women's studies Program, to ask her cooperation. She, also, wrote a letter to the graduate school in which she outlined the additional course work [teaching of some Women's Studies classes on feminist pedagogy; scholarly papers] that the Women's Studies Program would demand of me as a student. The additional course work 
ensured that I would receive graduate credit for the undergraduate courses. Gaining access to Women's Studies was thus quite procedural, involving only the writing of the forementioned letters. Within two to three weeks I had full permission from the graduate school to pursue Women's Studies as my cognate area.

I proceeded with a great deal of enthusiasm to take two Women's Studies--Introduction to Women's Studies, and Women and Creativity, in the Fall of 1988. I continued with a third course, Feminist Theory, in the Spring of 1989. My experience of these courses was discussed at length in the Prologue.

As a student in Women's Studies over the period of a full academic year, I was struck by the transformative agenda of the feminist teachers. Hence, given my experience in Women's Studies classes [which could be described, I feel, as the stage of initial data collection, however "informal" or unintentional], and my continuing interest in Neo-marxist literature, the notion of academic feminist as "transformative intellectual" emerged in a dialectic fashion, each idea in tension with and transforming the other.

One year from the time I had initially applied for Women's Studies as my cognate, I was back in the office of the interim coordinator, this time to discuss my research proposal. Yet again I found the coordinator, Chloe [who was eventually to participate, as one of the three academic 
feminists, in the study], extremely helpful and most encouraging. I explained my research study to her in her office in the basement of Soujourner Hall, the central office of the university's Women's Studies Program. Having the status of a program, rather than a division or department, the Women's Studies Program had no faculty of its own per se. Women's Studies courses were taught by professors drawn from other departments on campus-- predominantly from the English department, but also from the Center for the Humanities, and also the Biology, History, Sociology and Family and Child Development departments. However, the university had designated a full-time position of coordinator to the program. Chloe was acting coordinator while a search was conducted for a new, permanent coordinator. Before I began my research, in the Fall of 1989, Pauline had been employed as the new program coordinator, on a joint appointment with the History department.

Chloe, in her capacity as interim leader of the program, gave me permission to begin my research within the Women's Studies Program. At that meeting she advised me to speak to the Dean of the College of Arts and Sciences regarding my research intentions; the Women's Studies Program lay within the curriculum of Arts and Sciences.

I immediately followed up on her suggestion and called the Dean that afternoon. I explained the research objectives briefly, but carefully, to him, emphasizing "critical 
pedagogy" as the focus of my study. Expecting that he would wish to meet with me to discuss the research at greater length, I was surprised when he remarked [and I paraphrase], "If Chloe has spoken with you and she is satisfied, then that's just fine with me. I wish you "Good Luck"!" Laying down the phone after that conversation I remembered, smiling, the long ethnographic accounts I had read entitled, "Access to the Site"; it seemed that I was to be spared the frustration and anger that often precipitates in the development of those accounts! Gaining access seemed to be so simple.

Though I had permission to work within the Women's Studies Program area, as yet I had neither selected nor approached the feminist professors with whom I wished to work. I knew that I needed to deal with this major question before everyone left the campus for the summer. I selected three women, Muireann, Chloe and Gale because they taught one of the three Women's Studies courses in the Women's studies Program--Introduction to Women's Studies, Feminist Theory and the Women's Studies Senior Seminar, respectively. I believed that participant observation [including fieldnotes and audiotaping] across these particular courses would give a broad view of students that participate in Women's studies courses--from "Ereshmen", to Sophomores and Juniors, and on to Seniors. Moreover, I wanted to explore different curricular levels in the program in terms of course content 
and pedagogical approach [if any differences existed]. However, I should point out that the primary focus of my study, from the outset, was the teacher. My interest in students and course content were significant only insofar as they helped me toward an understanding of the teachers in question. Clearly, I could not explore the lives of teachers without paying careful attention to their students.

The three academic feminists who taught these courses and who agreed to participate in the study were affiliated with the English Department. Chloe was a tenured, associate professor in her late-thirties; she was a literary critic. Muireann was thirty years old and held a Master of Fine Arts degree. She was employed by the university as a full-time instructor and was entering her seventh and final year of her term appointment. This particular institution did not grant tenure to instructors without doctoral degrees. Finally, Gale was a professor of Renaissance literature in her mid-forties. She was in her second year at the university, on a joint appointment with the English Department and the Center for Humanities, and working toward tenure.

The only professor with whom I was friendly at the selection stage was Muireann; she had taught the Women and Creativity course which I had taken, as a student. My reason for selecting her [there was one other teacher teaching a section of Introduction to Women's Studies in Eall of 1989] was basically that I felt she would be interested in the 
work. I also felt secure in our relationship; we knew and liked one another. I was not disappointed with Muireann's response to my invitation to participate in the study. Once I established the fact that the study would not make too great time-demands on her, she expressed enthusiasm and support for the work.

Gale and Chloe reacted similarly. Basically, they accepted my invitation telling me that participating in the study would be a wonderful opportunity, but they were very concerned about the time involved. I learned through this part of the research process--selection and invitation--the importance of outlining very carefully, for research participants, the time demands that were to be made upon them. In this case, I expected to be a participant observer in the classrooms for a semester and also to attend the Women's Studies Faculty Advisory Committee Meetings [in which Chloe and Gale were involved]. Additionally, I wanted to conduct a series of four interviews with each professor over the academic year 1989/1990. As it transpired I had at least one major structured interview with each participant, lunch with Muireann and Gale on one or two occasions, informal chats on the telephone with each professor and informal meetings with them in their respective homes. Often the informal phonecalls and lunches were the most informative sources but I had to rely on memory when writing down notes afterwards, [an activity which can be frustrating]. None of 
the participants ever complained as to the time demands of the study; in fact as the project progressed they seem to become increasingly more interested and willing to involve themselves.

I was impressed with the professors' concern that the students participating in the study, that is, those interviewed, would be protected in as far as possible. I issued permission forms outlining the research and the intended role of participants to students and teachers. [Appendix C]. All permission forms were signed by participants and researcher; I gave copies to students and teachers involved.

The University Human Subjects Protection Committee, and the Provost for Research, were satisfied that the terms outlined in the permission forms constituted sufficient protection for all research participants.

The Summer of 1989, before the research proper began, passed quickly. I spent my time working for a Literacy Tutoring Company in Honolulu, as well as reading any literature I felt relevant to my research project. Muireann gave birth to her first child in July of that Summer--a daughter. Later on, I learned that Chloe spent some time that Summer in Germany, with her colleague Lena, where she gave some lectures on Women's Studies in the United States. Gale spent most of that Summer in England researching a Renaissance woman writer, Eliza Haywood, in British 
libraries. The research respondents and I had returned to campus for the Fall semester. I was ready to begin. An Important Premise

I decided early on to situate my research within a theoretical framework called symbolic Interactionism. Symbolic interactionism focuses upon social processes, and the meanings that individuals attribute to social situations. The basic premises of symbolic interactionism are as follows: first, that "people are constructors of their own actions and meanings" (Woods, 1983). People live in a physical world, but individuals may ascribe different "meanings" to objects in that world. The second premise of symbolic interactionism is that meaning arises out of interaction between individuals and groups. Socially constructed meanings are further interpreted by the individual, revised and used to guide subsequent action. This then is the third premise of symbolic interactionism. The individual is seen as an agent who "selects, checks, suspends, regroups, and transforms the meanings in the light of the situation in which $s /$ he is placed and the direction of his/her action" (Blumer, 1969: 5). [See Appendix $D$ for an extended description of Symbolic interactionism. ]

\section{A Case of....}

From the moment that I decided to explore the lives of three radical teachers it was clear to me that a case study 
approach was the most appropriate. There are a number of reasons that this approach was important to this particular study.

I chose a case study approach because it allowed me to confront abstract Neo-marxist theories of radical teaching, by portraying what appeared to be happening to radical teachers in schools, in their classrooms, conference rooms, and in their personal/professional lives. Walker (1980) suggests that a case study is the examination of an instance in action. As such case study research involves a commitment to the individual instance. Much of Neo-marxist literature on education, which served as a framework for this research, is weighed down by generalities and abstract concepts. As Walker (1980) points out it may be that it is less a problem of theory than a problem of access to knowledge that might inform theory.

As I portrayed each participant in a different case study, I had the sense that I was endorsing individual lives as idiosyncratic and particular, not shaped to fit neatly into any superimposed theoretical framework, but as legitimate in their own right.

The case study can be individualized. Each person can clarify the similarities and the differences in his/her own setting, his/her own organization, his/her own personality. (Smith, 1974:7)

However, there is another reason why the case study approach was important to this research--theory. Mitchell 
(1983) characterizes case studies as a "detailed examination of an event (or series of related events) which the analyst believes exhibits (or exhibit) the operation of some identified general theoretical principle" (192). The second objective of the study referred to its importance to informing the theoretical concept of "transformative intellectual" in the Neo-marxist literature. The activities of academic feminists suggest a "transformative" agenda. Eckstein (1975) describes the use of case studies in the development of theory as heuristic. The case study can be ...deliberately used to stimulate the imagination towards discerning important general problems and possible theoretical solutions.... Such studies...tie directly into theory-building....

Eckstein (1975: 108)

Eckstein is referring here to the possibility of finding relations between aspects of a number of case studies; as such these relations are generalizable and can be used to extend, modify or eliminate elements of given theories. By exploring connections, commonalities and differences across the lives of three academic feminists I feel that I have provided some empirical grounding for a critical theory of education that cites teacher as a "transformative intellectual". I have represented my explorations of critical theory, in light of the three case studies, in Chapter 3 of this document. 
As my data collection proceeded, I was struck by the differences between the teachers involved in the study. If the work of Muireann, Chloe and Gale suggested a transformative agenda, then each teacher seemed to represent an instance in transformative action. I was satisfied with my earlier decision (made in the process of writing my research proposal, Fall 1989) to take a case study approach.

\section{In the Field....}

Data collection consisted of participant observation in three, semester-long, Women's Studies courses I had selected. As a participant-observer in these courses, I took fieldnotes of all classroom interactions. In addition, I audio-taped in two courses--Feminist Theory 3000 and the Senior Seminar. After every class period, I made a journal entry, recording in detail my own response to the class as well as any thoughts, feelings, insights regarding the teacher as a potential "transformative intellectual".

I conducted interviews dealing with the personal biography and professional lives of each of the three teachers. I intended at the outset to conduct at least four "formal" interviews; by "formal" I mean face-to-face, structured interviews, in some university office. However, as the year progressed I decided that one, two-hour "formal" interview was sufficient, the latter being supplemented by other more informal and often more informative meetings. I 
met with each teacher in her home after which I. made my notes from memory; I had lunch with both Muireann and Chloe on separate occasions, after which I also made copious notes; finally, there were numerous phonecalls which again demanded note-making from memory.

Before I began any interviewing, I laid out a series of topics that were of specific importance to my study. Personal life history, interest in feminism, goal as a Women's Studies teacher, role as a university professor, experience of teaching Women's Studies in this specific university were some examples of such topics. I also asked questions that led teachers to explore the current Women's Studies course with which she and were involved. Usually, all I had to do was ask, "How do you feel about the course?", and the teachers would reflect openly and candidly about their experiences of teaching therein. During these interviews I asked very broad questions allowing the teachers to select items they wished to discuss, and not to discuss, with me.

Having lunch with the professors, or eating dinner at their homes, provided a far more relaxed setting for discussion. At these times I followed the line of conversation begun by the teachers who spoke about family, personal history and their various experiences at the university without any prompting on my part. I think that at these times the teachers were still aware that even 
without my taperecorder I was still "researching", and they wanted to contribute; however, as Gale once commented, they "felt they could interact with me as a real person without "that" taperecorder".

Interestingly, during all our conversations the teachers would interject with questions; they were interested in my personal history, my plans after the dissertation, my interest in feminism and also my impressions of how their respective courses were going. Being a rather private person, I was reticent at first to answer the more personal questions but I realized that I must do so; if I did not I was no better than a "voyeur", with no interest in the reciprocity of the research process. I had to remind myself that by my entering into "conversations" rather than "interviews" the research process would be a learning experience for all participants, including myself.

I chose four to five students from each teacher's class to interview. My selection was based on gender, race and degree of overt participation in the classroom discourse. I chose to interview only women as I wished my study to involve only women, thereby validating the voices and experiences of women. I tried to ensure that I chose a representative group of Caucasian and African-American students from each course. Also, because of the teachers' concern with students' voices being heard in the classroom context, I wanted to record the reactions of both "silent" and "talkative" students to the 
classroom processes. I interviewed each student on one occasion. The interview was quite structured and I asked questions regarding, student's perception of self in the classroom, of the professor in question, of classroom interactions, of Women's studies generally; students' feelings about the course, students' initial expectations of the course, and finally, I asked students to talk briefly about their own personal histories. Often students raised issues that were obviously very important to them. For example, a number of lesbian students were greatly concerned about the treatment of the issue of homosexuality in Women's Studies classes.

In addition to participant observation and interviewing I collected data [using fieldnotes and audio-tapes] at faculty advisory committee meetings in which two of the participants [Chloe and Gale] of the study were involved.

\section{In the Field, Together!}

As I began the phase of data collection I felt somewhat apprehensive about the research upon which I was about to embark. I was a novice ethnographer--that was certain; my new taperecorder itself was enough to intimidate me! I had little experience with fieldwork [I had done a small scale study in a Montessori school for my Ethnographic Research Methods course]. I was particularly concerned with the 
development of trusting relationships with the informants in the study--with students, but particularly with the teachers.

As a graduate student, I was aware of the power differential between the professors and myself, a graduate student; in effect I was "studying up". How should I refer to the professors, for example--as Dr. So and So, or as "Gale", "Chole" and "Muireann"? Names were important I felt because they set the tenor of the relationships in many ways. Another concern was the very important fact that I was still conceptualizing my research study as I began data collection. As a student in my doctoral program I was scheduled to defend my dissertation proposal in December 1989. However, I began to collect data in August 1989. I remember being concerned that when discussing the research with the academic feminists I would seem uncertain or ambiguous, thus jeopardizing my credibility in their eyes.

My apprehensions were diffused as the data collection proceeded. I bought a battery recharger for one thing! Knowing that at least my batteries wouldn't "run out" was reassuring when I was in the field! I also learned that any effort on my part to "hide" the taperecorder, an object which represented my role as "observer/researcher", was both unnecessary and dishonest. In Gale's classroom [a Senior Seminar with eight participants], the taperecorder was always within students' view as it lay on my desk. In fact, Gale often referred to the recorder and myself as "voyeurs". In 
a seminar on Women and Representation it was indeed ironic that I was there to observe and subsequently represent the female participants--a play within a play, as it were. However, rather than make me feel uncomfortable or conspicuous, Gale's comments on my role as "voyeur" introduced a note of humor into the setting and released some of my own tension that arose from being there.

Taking fieldnotes posed little apparent problem for me in any of the three classroom contexts--notebooks and pens seemed to be the mainstay of university classrooms. My fieldnotes attracted attention on only one occasion--in the Introduction to Women's Studies course. During the first week of class I sat beside a young woman who seemed extremely curious about what I was writing down in my notebook. Throughout one class period she persistently looked "over my shoulder" to read my writing. I was rather taken aback by her persistence and decided to ignore her behavior. I remain ambivalent about my choice. Perhaps I should have invited her to read my fieldnotes; such an approach might have led to a valuable relationship with that student. However, at the time I felt so vulnerable that I shied away from dealing with the situation directly.

"Studying up" didn't pose a problem after all. Muireann, Chloe and Gale insisted that I call them by their first names. This was a trend I noticed in the context of their relationships with their students; the importance of relating 
on first name terms, so as to diminish the power differential between students and teachers, is spoken about in the literature on feminist pedagogy. All three academic feminists treated me cordially and expressed interest in the study. Gale, for example, would call me on the phone to share book titles and articles that might be of interest and use to me in my research. I felt greatly encouraged by their interest in the study, and when it became time for me to defend my research proposal I invited them to sit in on the examination. Gale had a prior appointment [research conferencel, but both Muireann and Chloe participated in the examination. All three read the proposal.

The feedback I received from the academic feminists at that stage was important. They told me that they understood both the project and its methodology; most importantly, perhaps, they unilaterally expressed the view that the study would be both a means of expanding their understandings of their feminist pedagogy, and a vehicle for drawing attention to and exploring Women's Studies as a marginal phenonomen within the university.

During one of our conversations, Gale showed an appreciation of the ethnographic process, having herself taught a course on ethnographic writing and shared an office with a graduate student who had carried out an ethnographic study. Gale expressed regret at not being able to do an ethnographic study for her own dissertation. Gale's 
knowledge of the research methodology--the research process, journal writing and analysis--as well as her words of encouragement to me, made me believe that she understood "what I was about", and had confidence in my ability.

After that I felt no need to "explain myself" as a researcher; she understood, and I found tremendous comfort in that.

On Chloe's invitation, I chaired a panel discussion of academic feminists in my study and others from the university, during a weekend conference of the South Eastern Women's Studies Association. The invitation provided a signal to me of Chloe's confidence in my work.

During her illness, Muireann called me to ask if I would teach one of her classes on "Women and Religion"; her request implied her trust in my ability, also.

My relationships with students were also important. I felt accepted by students, particularly those in the Eeminist Theory and Senior Seminar. I knew many of the students because we had taken other Women's studies courses together. I felt particularly comfortable with my relationships with students in the seminar setting, in part because the course content--post-structuralist theory was new to all of us. I was genuinely learning the material along with everyone else, although none of us really talked about our struggle with the material until near the end of the semester. 
I remember speaking at most on only two occasions in both Introduction to Women's Studies and Feminist Theory 3000. Each class had over thirty members and so it was much easier to "fade into the background", as it were. I felt that it was appropriate for me to be silent in these cases. I had been through both courses previously myself as a student and I felt more comfortable being quiet.

One concern that I had within the the context of researcher-student relationship in the seminar was my own verbosity. For the most part, student participation in the seminar was in the form of listening; $I$, on the other hand, was more willing to risk speaking about issues I little understood! Often I wondered and worried if my speech contributed to the students' silence in any way. Initially, I decided to interact in the seminar because I felt that to act otherwise would create an "artificial" relationship [and subsequently, environment] between me and the other participants. The reason for this was the small number of students involved. I made up one eighth of the seminar group so my silent presence would, I felt at the time, have rendered me very conspicuous. However, as it transpired, because of the silent nature of classroom interactions, my speech rendered me highly conspicuous! I think now that unconsciously, perhaps, I spoke so as to support Gale, the teacher, by answering questions and raising issues for discussion. During interviews students suggested by their 
responses that my "talk" didn't bother or impinge on them--"I always enjoyed listening to what you had to say", one student told me. Gale herself stated explicitly that she appreciated "my sense of my place as a researcher" in her classroom; I gathered from her comment that she was quite satisfied with my interactions. Nevertheless, I am left wondering if my decision to participate verbally was a "good idea"; I remain unable to determine my influence on the overall classroom interactions.

In the Introduction to Women's Studies I began to develop relationships with some students from the outset. I found that by getting to class early I could sit in different positions in the circle, talking and listening to different students, thus gaining some sense of the group.

In Chloe's classroom--Feminist Theory--I knew many of the students from my Women and Creativity course. Lesley, Kathy, Joyce were among those I knew. My friendships with students in this particular course developed specifically from our attendance at a Women's Studies Association Conference. A group of us travelled to the conference together, attended the various presentations and discussed our impressions of presenters and issues. Outside the university context, students talked candidly about the course-Feminist Theory-and their teacher, Chloe, without any prompting from me. There was a tremendous sense of camaraderie achieved that weekend; however, I felt a little troubled by the use I made of the 
experience for data collection. The students were aware of my role as "researcher" from the outset. Gale had asked me to explain my research project at the outset; Chloe had announced my role in her classroom on the second day of class; Muireann had introduced me as a student from the College of Education and gave me the responsibility to tell students individually, as I saw fit. Nevertheless, the question remains as to whether it would have been advisable to remind participants, in the interest of fairness, of my continuing role as researcher.

\section{To Talk, To Write, To Code: To Analyze}

My analysis of data had three dimensions, consisting of lengthy discussions with my advisor, and other members of my doctoral committee, throughout the research process, codification procedures, and also, the actual writing of the research representation.

Erom the outset of the study in August, 1989, I met with my advisor on a fortnightly basis to discuss the research. We talked at length about the teachers and the students with whom I was becoming acquainted. I described in detail the classroom processes, the insights I was having on critical pedagogy as well as the questions that seemed to be emerging. Those discussions took place in the context of writing my research proposal and as such informed that writing. In December 1989, I met with all five members of my doctoral 
committee in order to "defend" my research proposal. That meeting proved to be an informative one, and the comments of committee members were valuable in leading me to see avenues for analysis heretofore unconsidered--the affective roles of radical teachers in terms of care of and connection to students, being one example. During the Spring of 1990, during which I continued to meet with my advisor, I also met with an educational anthropologist [a committee member] for a series of three two hour meetings during which we discussed emergent themes from the study--"knowledge" and "theory" are examples.

My intention at the outset of the research study was to collect and code data simultaneously. However, codification of data did not take place until the middle of the spring semester of 1990 when almost $90 \%$ of the data was collected. There were practical constraints that brought about this delay--writing my research proposal in the Fall delayed completion of transcription of audiotapes until spring; so without data in print form it was impossible to code data. I did discover that by transcribing all classroom and interview tapes myself that I became much more familiar with the data and in effect I began, early on, to do multiple readings of the data without realizing it.

The analysis of data had two aims: first, I wished to gain some understanding of each individual teacher on their own terms as academic feminists within the university; 
secondly, my aim was to inform the theoretical concept of "transformative intellectual" by using all three cases. In order to achieve the first aim, I read the data over and over in order to find themes particular to each or all cases. For example, the themes of "theory", "knowledge", "political position" emerged as important to the cases of Chloe and Gale. A theme coming specifically from the critical literature, that is, "personal experience" was pertinent in analyzing the case of Muireann in the Introduction to Women's Studies course. All themes were systematically analyzed across all three cases. I hoped that by working both inductively, incorporating "data-based themes"--particularities at the case-level--and deductively, incorporating "literature-based themes"--abstractions from critical theory--that I might achieve an integrated approach to analysis.

Codification procedures in this research took the form of the Constant Comparison Method (Glaser \& Strauss, 1987). Generally this method is used to generate theory; however, in the current study my aim was to inform theory, more specifically, the theoretical concept of "transformative intellectual". Generally, the stages of data analysis consisted of coding incidents and responses into categories and comparing incidents applicable to those category, integrating categories and their properties, making assertions, and comparing and contrasting assertions from 
data with major assertions of critical theory. Below I explain my process of analysis by using the theme of "teacher authority" from the critical literature.

I read and reread interviews with students and teacher in Case 1, to explore how "authority" was spoken about by them. I categorized student and teacher responses around the theme of "authority". Categories included: contradiction in relationships--teacher or friend?; authority of feminist position; teacher's verbal relinquishing of authority. I then carefully read through Case 1 fieldnotes and journals to check categories. On the basis of reading, I reformulated existing categories and generated several other categories on "authority", such as problem students and teacher authority; teacher's sharing of personal experience; teacher's invocation of feminist politics using her authoritarian position.

Each response from the interviews and each incident from the fieldnotes was coded into a specific category under the theme of authority. I examined each response and incident and compared it to others within the category in order to specify dimensions underlying the discrimination that the particular category made. For example, one category that emerged in the interviews was the "teacher-friend contradiction". Under this category I coded comments such as: "the teacher's good to sit and chill with!" and "She's not like any of the other teacher's I've had...she's a 
friend." I also coded comments that reflected the other side of students' reactions such as: "She wants an answer pronto!" and "She wants her opinion to be our opinions." I decided that the underlying dimension of the category was "Distance--Closeness" where the students perceived Muireann as a friend but also as an authoritarian figure, a teacher, from whom they had a certain set of expectations in terms of relationship.

I generated my assertions inductively by trying to explain what I saw in the data, then making statements that accounted for data, which I subsequently tested further across cases. I asserted that the dimension "distance--closeness" pointed to a negotiation of a relationship between students and teacher. The negotiation of the relationship was influenced by the students' school-script informed by previous school experience of teacher-role definitions--grading, assignments and non-personal interactions. Students were learning how to accommodate "new" or different role-definitions--how Muireann shared her personal experiences with them or relinquished teacher-authority verbally, "I'm standing up here on the platform but this doesn't mean that I know anything", for example.

After I had generated assertions, I moved the analysis to the other cases in order to explore the data in terms of categories and dimensions that emerged from Case 1. The 
assertions that I made on the basis of my analysis of Case 1 were compared and contrasted to those of the other two cases. In Case 2 and 3, for example, teacher authority was defined more in terms of "knowledge", more specifically, knowledge of feminist and post-structuralist theories, than in terms of teacher-role definitions. The redefinition of teacher authority in terms of self-disclosure, or the teacher's verbal relinquishing of authority, were not as important a factor in either case of Chloe or Gale. Issues of knowledge and power, as connected to the theme of "teacher authority", became the focus of attention in both Case 2 and Case 3, which led me back to Case 1 again to reanalyze for the categories I had previously generated.

Data analysis was far from a linear affair. My approach was very much web-like in nature, "to-ing and fro-ing" from case to case. I found it extremely difficult to isolate themes in the sense that to speak of "teacher authority" was to speak of "knowledge-power nexus", "institutional authority", "political discourse of the teacher" and "student voice" issues, also. Copious hand-written notes were the only way that I could keep track of the analysis [Appendix E]. I organized my analysis of responses [interviews] and incidents [fieldnotes] by actually coding my transcripts with pencil [A: authority; $T$ : student talk] and also summarizing the response or incident in a separate notebook. Entries in this notebook appeared as follow: Case 1/Authority/Naomi 
Interview transcript, page 5/teacher-student relationship-student expectations-Muireann is irritating, not radical enough-soft-voiced [Appendix E]. I also drew diagrammatic representations of themes and categories. These diagrams constituted in some instances an analytic process and in others a synthetic process. As such the diagrams proved important to my interpretation and very useful during the writing process.

Writing constituted an important part of my data analysis. In my daily journal, I included observations, concerning similarities and differences among cases, and insights into important connections between the critical literature and the teachers' lives, connections which I was beginning to construct.

Throughout the codification phase of my analysis I wrote short two-to-three page essays about emergent themes, such as feelings of marginality among the individual teachers, teacher authority, and problems posed by academic feminists in the institution. I like to think of these essays as the "playful" part of my analysis, wherein I "played with" assertions and ideas without making any definite commitment to them. Many of these ideas became important to my interpretation of the cases and as such I incorporated them into the main body of the final research text.

In the process of writing my first draft of each case, I found myself reformulating and refining assertions that I had 
made earlier in my analysis, as well as generating new assertions. In the case of Gale I explored the "private-public" tension in her life only after I had written my first draft of the case. Initially, I had accounted for the complexity of Gale's classroom processes in terms of the nature of post-structuralist theory. Soon I realized after reading the draft, discussing the case with my advisor and returning to reread my data, that this case could not be explained in terms of "a difficult theory". I began to explore Gale's personal history as an important source of insight to understanding Gale as an academic feminist; hence, my "final" interpretation in this document.

\section{To Bias or Not to...?}

A major concern of mine throughout the research process was the openly ideological nature of my study. The study was firmly embedded in a naturalistic paradigm of educational research. Naturalism maintains that all inquiry in value-bound--values of inquirer, choice of research paradigm, choice of theory to guide the research (Lincoln \& Guba, 1986). Gitlin et al; (1988) write that researchers no longer ask the question of whether the research is biased but instead ask whose bias is reflected by the research. It is clear that my decision to study the lives and activities of academic feminists reflects my interest and support of those activities. The choice of Neo-marxist theory to guide the exploration reflects my interest in education as a process 
of political conscientization, and schools as instruments of change. Throughout the study, I hoped that my interests constituted an "enabling prejudice", the advocacy nature of which might facilitated some change.

The attempt to produce value-neutral social science is increasingly being abandoned as at best unrealizable, and at worst self-deceptive, and is being replaced by social sciences based on explicit ideologies.

(Hesse, 1980)

However, though naturalism [Lincoln and Guba] admits to value-laiden inquiry, I agree with Pattie Lather when she rouses educational researchers to challenge the naturalistic tradition towards an emancipatory intent.

...research not directly linked to an emancipatory intent embedded in an openly acknowledged opposition to the maldistribution of power that underlies our society, consciously or unconsciously, perpetuates the status quo.

$$
\text { (Lather, 1983: 63) }
$$

A social science that emphasizes concepts of "neutrality" and "objectivity" serves to mystify the value-laiden nature of research and accordingly, legitimates privilege based on class, race, and gender (Lather, 1986).

Lather (1986) suggests that there are at least three research programs that incorporate to varying degrees an emancipatory intent--feminist research, Neo-marxist critical ethnography, and Freirean "empowering" or "participatory" research. My work drew from the Frierean notjon that 
research can serve as a process of empowerment for its participants. In an effort to avoid the reconstruction of relations of domination between inquirer and respondents, and to serve as a catalyst for further transformative work on the part of academic feminists, I evaluated my research along two criteria: the creation of a practice of the present; and the development of a text that represents the lives of others without violating their realities.

Gramsci (1971) describes "a practice of the present" as a process of facilitating the development of progressive groups to become more self-conscious in their particular social contexts. Gramsci (1971) suggests that intellectuals take the role of facilitators. Taking Gramscj.'s suggestion a little further I suggest that in research there is the possibility for a mutual development of self-consciousness by inquirer and respondents. Self-consciousness involves the individual in linking everyday life, or theories and understandings that inform those lives, with the social and historical processes by which ideas are determined and are determining (De Lauretis, 1986). By means of conversation and discussion all participants can benefit. Each one involved is led to reflect on what Held (1980) calls the "existent"--forms of social life that are realized in daily practice.

During the research process I was invited by the new coordinator of Women's Studies, Pauline, to participate in a 
faculty retreat. The retreat took place at Pauline's home and involved at least twenty Women's Studies teachers from across the disciplines [including Chloe from the study]. One rainy Saturday, from $9 \mathrm{a} . \mathrm{m}$. to $4 \mathrm{p.m}$., we sat and discussed "feminist" pedagogy as enacted in each individual's classroom. I participated actively in the discussions, sharing insights I had gained from my extensive classroom observations [participants' identities were unknown to most of the teachers at the retreat]. I learned a lot that day about the commitment and effort these academic feminists were prepared to spend on their program. I was encouraged to reflect more deeply on my own teaching and associated issues such as self-disclosure, and student resistance to liberatory/radical pedagogy and curriculum. It was gratifying when some weeks later, Chloe told me that my comments had been very helpful to her in terms of her personal pedagogical reflection. Conversations with Women's Studies professors such as those at the retreat, as well as those which occurred during the more structured interviews, helped, I hope, to sustain a process of self-conscious, self-critical analysis on the part of the participants and subsequently, enlighten action towards feminist, transformative goals. My knowledge of the effects of my work toward these ends remains largely incomplete.

If my work attempted to create Gramsci's "practice of the present" in its support of the emancipatory work of academic 
feminists, it thereby created a researcher bias. Some readers may insist that my approach [as a feminist studying academic feminists] was overly subjective and constituted "non-science". I would remind those critics, however, that good science may in fact be honest science. To conflate notions of scientific rigor with ideological neutrality may reduce objectivity to no more than a "canonized methodology for establishing scientific knowledge" (Lather, 1983).

However, the necessity to make my research findings credible, or "good", was clear to me, from the outset of the project. Whatever the researcher bias self-corrective techniques had to be formulated to "check the credibility of [ ] data and minimize the distorting effect of personal bias upon the logic of evidence" (Kamarovsky, 1981). Kamarovsky makes the distinction that we find reiterated by Guba and Lincoln (1981) regarding researcher neutrality versus data neutrality.

The task of achieving validity becomes the development of data credibility checks to protect our research and theory construction from our enthusiasms and incompetencies.

(Lather, 1983: 67)

In an attempt to make my research credible I took a number of steps. First, I ensured that I cross-checked my data by by use of multiple data sources and methods. I collected data from teachers, students and members of the Women's Studies faculty advisory committee; I also used documents 
such as course syllabi and any written communication between students and teachers in the form of letters and homework assignment sheets. Moreover, my methods of data collection consisted of both interviews and participant observation in classrooms and at meetings.

Second, in order to ensure the credibility of my exploration of the major theoretical concept of the study, "transformative intellectual", it was important to unceasingly confront the theory with the everyday experiences of academic feminists; in this way, I tried to avoid the imposition of theory. I designed the interviews to facilitate the expression of individual motivations and rationales for activities by the academic feminists. I also invited each respondent to read my research proposal so as to allow them to criticize the theoretical concept as it is described in Neo-marxist terms in this research.

Throughout the writing process of the research study I was keenly aware of the issue of fairness. The process of representation must be, at the very least, sensitive to questions of justice and equity in the treatment of research respondents.

This research study, as all research, rendered its subjects vulnerable, "at grave risk of manipulation and betrayal" (Stacey, 1988). The nature of participant-observation as an intrusion and intervention into a system of relationships "that the researcher is far freer 
than the researched to leave" is problematic in terms of mutuality and reciprocity. Stacey (1988) sees the nature of naturalistic research as unavoidable. Her metaphor is a particularly vivid one....

The lives, loves and tragedies that fieldwork informants share with a researcher are ultimately data, grist for the ethnographic mill, a mill that has a truly grinding power.

(Stacey, 1988: 23)

Stacey's (1988) comments gave me cause for concern as I analyzed data and prepared the final representation of the research--the case study in textualized form. Acker et al; (1983) are also concerned with data analysis and the creation of a final representation of the research....

How to produce an analysis which goes beyond the experience of the researched while still granting them full subjectivity? How do we explain the lives of others without violating their reality?

(Acker et al; 1983: 427)

The problem of research subjects' vulnerability became particularly acute because of the possibility of deception or discrepancy between my overt appreciation for respondents's during my attempts to gain information, and covert indifference for the respondents during the representation processes, which included data analysis and report writing. The problem was exacerbated in the report because text has a life of its own--a public life. In hindsight, I see my dilemma during the representation 
process, which must by its nature involve selection and simplification of data, in terms of voice, authority and authenticity.

Voice" became problematic for me as a writer when readers of the final text began to ask, "Now, who is saying this, is it you, the teacher, the students or some critical theorist?" Though I believed that I had clearly outlined who had said what, I found that, in fact, my text was often misleading and ambiguous. My use of representational devices, such as dialogue and vignette, served to obscure rather than clarify the voice of the speaker--researcher or respondent. The dilemma here is really one of audience. I agree with Bruno Latour (1988) who says that "all literary devices must be mustered to render an account lively, interesting and perceptive". However, there is a danger in allowing the strength, creativity and coherence of a representation precede as fair a representation of respondents' voices as possible. In Chloe's case I used "dialogue" to represent what I had interpreted as her "inner conversation"; I constructed the dialogue using Chloe's words spoken in both classroom and interview contexts. Chloe indicated her complete satisfaction with my representation, telling me that she felt extremely comfortable with it.

The issue of "authenticity", that is, the trustworthiness of my account, was a noteworthy area of concern. Initially, I was totally overwhelmed with the complexity of the data; 
there seemed to be no way that I could create "a patterned order from the chaos of a continuous flux" (Stoller, 1989). When faced with the complexity of three individual lives, was I really trying to find some commonalities, some "invariants beyond empirical diversity" and if, out of zeal, I "found" such common threads, had I artificially inserted them? When I represented the work and lives of three teachers in terms of "struggle" how authentic, or fair, a representation was this? Reminiscent of the meno paradox, I was left wondering, "How do I know that I know?"

Finally, the writing stage of the research reintroduced my earlier concern over ethnographic relationships. For the first time throughout the research process I was highly aware of my authority as a researcher. However, part of this realization I owe to my readers. They pointed out to me how, for example, my use of tense functioned to construct each participant as an "other". In a rereading of my draft I began to understand that by using the present tense I was, in fact, magnifying my claim of credibility. I had presented teachers and their lives as almost static like in quality, they were seen to exist here, now and for eternity. If I had used past tense I could have avoided this problem of representation because past tense is reminiscent of story forms, and historical discourse. Thus I could have represented the teachers and life in their classrooms as transient, passing, indeed "past" as those moments of participant observation 
are. The use of present tense may have constituted a cognitive stance toward the another as "other", out there as the "object" of my observations. Hence, I have represented myself, in effect, as the all-seeing "voyeur", the very thing that I had tried to avoid from the outset. Ironic, indeed!

\section{A Question of History}

Though symbolic interactionism proved to be both a highly appropriate, and a very useful, theoretical orientation in the construction of the case studies, I found it to be "incomplete" in some respects. Symbolic interactionism led me to focus on classroom "events" and "situations", and students' and teachers' responses to those events, as items of analysis. Examples of such "events" were a "problematic" interaction between Marian, a lesbian student and her classmates; and a "heated" discussion between Chloe, the professor, and one particular student, Kelly, who felt silenced. However, it soon became clear to me that the way in which the three teachers taught Women's studies could not be completely understood in terms of the ongoing classroom events. Personal history and also the broader life context of the teacher were also important histories. Hence, to focus on class events only would have limited the research project, I feel. By exploring each personal history I was able to make connections between individual teacher biographies on the one hand, and pedagogical processes on the 
other. Chloe, for example, felt that she had knowledge to impart to her students but she didn't know how to separate the power and privilege that this relay of knowledge gave her. My exploration of Chloe's personal/professional history led me to assert that Chloe was still harboring the voice of the "conservative intellectual" she once was--in her own words, "a male model" of academic success; this part of her wished to transmit and relay knowledge to her students. Thus, during the research process I came to more fully appreciate Ivor Goodson's (1989) words, that

$$
\begin{aligned}
& \text {...in understanding something so intensely } \\
& \text { personal as teaching it is critical that we } \\
& \text { know the person the teacher is. }
\end{aligned}
$$

In Case 3, Gale's religious background, and the "privatized, emotionally supportive role" to which she was assigned as a Mormon woman, seemed vital to understanding her approach to her academic career, as well as her struggle to control her new public role as professor. My analysis of Gale's experience taught me that perhaps I should have extended the study to include not only personal history but also the socio-historical background of the individuals involved. This would have meant seeing the teachers,

$$
\begin{aligned}
& \text {...in relation to the history of [their] } \\
& \text { time, and how [they were] influenced by the } \\
& \text { various religious, social, psychological and } \\
& \text { economic currents present in [their] worlds. } \\
& \text { (Jackson, 1968) }
\end{aligned}
$$

At some point in the future, a follow-up study that would develop the socio-historical dimension of the lives of Chloe, 
Muireann and Gale might be interesting. If I can view the intersection of the life history of the teachers with the history of society, I think I might be better able to understand "the choices, contingencies and options" open to each of them (Goodson, 1989). Gale and Chloe grew up in the fifties and attended college in the sixties--what was happening in the United States at that period that might have influenced them or created differences between them and Muireann, who grew up in the sixties and attended college in the late seventies? There are interesting questions still to be addressed here. I agree with Goodson (1989) when he states that we "must constantly broaden the concern with personal truth to take account of wider socio- historical concerns even if these are not part of the consciousness of the individual (p. 12).

\section{A Einal Word... For Now!}

Every stage of this research project had its frustrations and joys. More than ever, I have learned to appreciate the complexity of human lives. To understand the "changes, growth and intensity" with which lives are experienced is no easy task. The major objective of the present study was to explore the lives of three academic women. I hope that in studying the lives of women I have demonstrated value for the experiences of women generally, experience which has hitherto been denied as real and important (Reinhartz, 1983). 
Moreover, I hope that my study of "lived experience" points to the need for a re-definition of the construct "experience" itself as "interesting (not arbitrary), effective (in the sense that our ideas shape our world and are not simply shaped by it), uniquely human, and contextual" (Reinhartz, $1983)$.

I somehow knew that there are worlds that we do not know or understand. I learned that life was more complex than what I had believed as a child. It was Henry James who recognized the futility of attempting to live over other people's lives without living over their perceptions and the changes, growth, and intensity with which they experienced those lives. We all live in different worlds, and only in rare moments do we obtain a glimpse of another's world.

(Carol Stumbo, 1989)

This study was one attempt to provide such a glimpse. 


\section{REFERENCES}

Acker, J., Barry, K. \& Ersveld, J. (1983). Objectivity and truth: problems in doing feminist research. Women's studies International Eorum 6.

Alcoff, L. (1988). Cultural feminism versus poststructuralism: the identity crisis in feminist theory. In E. Minnich et al; (Eds.), Reconstructing the Academy. Chicago: The University of Chicago Press.

Apple,M. (1985). Education and Power. London: Routledge \& Kegan Paul.

Arendt, H. (1958). The Human Condition Chicago: The University of Chicago Press.

Aronowitz, S. \& Giroux, H. (1985). Education under Siege: The Conservative, Liberal and Radical Debate over Schooling. South Hadley, M A: Bergin \& Garvin.

Aronowitz, S. (1986). Schooling, popular culture and post-industrial society: Peter McLaren interviews Aronowitz. Orbit, $17,18$.

Ballantine, J. (1983). The Sociology of Education. New Jersey: Prentice-Hall, Inc;

Belenky, M. F. et al; (1988). Women's Ways of Knowing. New York: Basic Books.

Berger, P. L. (1969). The Social Reality of Religion. New York: Faber.

Berlak, A. \& Berlak, H. (1981). The Dilemmas of Schooling. London: Methuen.

Berlak, A. (1989). Angles of Vision. Unpublished paper presented at the American Educational Research

Association annual meeting. California: San Francisco.

Blumer, D. C. (1969). Symbolic Interactionism: Perspective and Method. New Jersey: Prentice Hall Inc.

Boggs, C. (1976). Gramsci's Marxism. London: Pluto Press.

Bordo, S. (1988). The cartesian masculinization of thought. Signs 11.

Boxer, M. (1988). For and about women: the theory and practice of Women Studies in the United States. In $E$. 
Minnich et al; (Eds.), Reconstructing the Academy.

Chicago: The University of Chicago Press.

Bowles, G. \& Duelli-Klein, R. (1983). Theories of Women's

Studies. London: Routledge \& Kegan Paul.

Burke, K. (1961). Attitudes Towards History. Berkley: University of California Press.

Bruner, J. (1986). Actual Minds, Possible Worlds.

Cambridge: Harvard University Press.

Code, L. (1989). Experience, Knowledge and Responsibility. In Feminism and Philosophy.

Collins, R. (1979). The Credential Society. New York: Academic Press.

Connel1, R. (1983). Which Way is Up? Essays on Sex, Class and Culture. London: George Allen and Unwin.

Cott, N. (1986). Feminist theory and feminist movements: the past before us. In J. Mitchell and A. Oakley (Eds.), What is Eeminism? New York: Pantheon Press.

Cinnamond, J, \& Zimpher, N. (1990). Reflectivity as a function of community. In Renee Clift, $W$. Robert Houston \& Marleen Pugach (Eds.), Encouraging Reflective Practice in Education. New York: Teacher's College, Columbia University.

Culley, M. \& Portuges, C. (1985). Gendered Subjects: The Dynamics of Feminist Teaching. Boston: Routledge \& Kegan Paul.

De Lauretis, T. (1986). Feminist Studies/Critical Studies: Issues, Terms, Contexts. Bloomington: Indiana Press.

Delmar, R. (1986). What is feminism? In J. Mitchell and A. Oakley (Eds.), What is Feminism? New York: Pantheon Press.

Dewey, J. (1897). My pedagogic creed. School Journal, 54: 77-80, 234 .

Eckstein, H. (1975): Case study and theory in political science. In F. Greenstein and N. Polsby (Eds.), The Handbook of Political Science. London: Acldison- Wesley. 
Elbow, P. (1986). Embracing Contraries: Explorations in Learning and Teaching. New York: Oxford University Press.

Ellesworth, E. (1989). Why doesn't this feel empowering? Working through the repressive myths of critical pedagogy. Harvard Educational Review, vol. 59, no. 3.

Finkelstein, B. (1984). Education and the retreat from democracy in the United States, 1979-198? Teachers College Record, 86 .

Foucault, M. (1980). Truth and Power. In P. Rabinow (Ed.), The Eoucault Reader. New York: Pantheon.

Eriere, P. (1973). Pedagogy of the Oppressed. New York: Seabury Press.

Euss, D. (1990). Essentially Speaking: Feminism, Nature and Difference. New York: Routledge.

Giddens, A. (1981). A Contemporary Critique of Historical Materialism. Los Angeles: University of California Press.

Gilligan, C. (1982). In a Different Voice. Cambridge, MA: Harvard University Press.

Ginsburg, M. (1988). Contradictions in Teacher Education and Society: A Critical Analysis. London: The Falmer Press.

Ginsburg, M. \& Clift, R. (1989). Seeking the hidden curriculum in teacher education. Paper presented at the Annual Meeting of the American Research Association, 2630 March, in San Franscisco.

Giroux, H. (1985). Introduction. In P. Friere, The Politics of Education. M A: Bergin \& Garvey Publishers.

Giroux, H. \& McLaren, P. (1986). Teacher education and the politics of engagement: the case for democratic schooling. Harvard Educational Review. 56, 3.

Gitlin, A., Siegel, M. \& Boru, K. (1988). purpose and method: rethinking the use of ethnography by the educational left. Paper presented at the annual meeting of the American Educational Research Association. New Orleans, Louisiana.

Goodson, I. (1989). Teacher's life histories and studies of curriculum and schooling. Paper presented at the 
Qualitative Research Conference, January 5-7, Athens, Georgia.

Gore, J. (1990). The struggle for pedagogies: critical and feminist discourses as Reqimes of Truth. Paper presented at the Annual Meeting of the American Educational Research Association, April 16-20, Boston.

Glaser, A. \& Strauss, B. (1967). The Discovery of Grounded Theory. Chicago: Aldine.

Gluckman, M. (1961). Ethnographic data in British social anthropology. Sociological Review 9: 5-17.

Gramsci, A. (1971). On Education. In Q. Hoare and G. Smith (Eds.), Selections from Prison Notebooks. New York: International Publishers.

Greene, M. (1988). Research currents: what are the language arts for? In Language Arts, Vol. 65, No. 5. September.

Greene, M. (1988). The Dialectic of Ereedom. New York: Teachers College Press.

Guba, E. \& Lincoln, Y. (1981). Effective Evaluation. San Francisco: Jossey-Bass.

Harding, S. (1986). The Science Question in Eeminism. Ithaca: Cornell University Press.

Held, D. (1980). Introduction to Critical Theory: From Horkheimer to Habermas. Berkley: University of California Press.

Hesse, M. (1980). Revolution and Reconstruction in the Philosophy of science. Bloomington, Indiana: Indiana University Press.

Holmes/Tomorrow's Teachers: A Report of the Holmes Group (1986). East Lansing, M I : Holmes Group, Inc.

Hooks, B. (1984). Feminist Theory: Erom Marqin to Center. Boston: South End Press.

Howe, E. \& Ahlum, C. (1973). Women's Studies and social change. In A. Rossi \& A. Calderwood (Eds.), Academic Women on the Move. New York: Russell Sage Eoundation.

Howe, E. (1975). Women and the Power to Change. New York: McGraw-Hill. 
Hurn, C. (1985). The Limits and Possibilities of Schooling. Boston: Allyn and Bacon, Inc.

Hutchison, C. (1988). Feminist theory and the humanities: the changer and the changed. Humanities in the South, 68.

Jackson, P. (1968). Life in Classrooms. New York: Holt, Rinehart \& Winston.

Jencks, C. (1972). Inequality. New York: Basic Books.

Kaestle, C. (1983). Pillars of the Republic. Toronto: McGraw-Hill Ryerson Ltd.

Kamarovsky, M. (1981). Women then and now: a journey of detachment and engagement. Women's Studies Quarterly, 10, 2 .

Kemmis, S. (1987). Critical reflection. In M. Wideen \& I. Andrews (Eds.), Staff Development for School Improvement: A Focus on the Teacher. New York: The Falmer Press.

Lather, P. (1983). Feminism, Teacher Education and Curricular Change: Women Studies as Counter-Hegemonic Work. Dissertation, Indiana University.

Lather, P. (1986). Issues of validity in openly ideological research: between a rock and a soft place. Interchange, vol. $17,4$.

Lather, P. (1990). Staying dumb? Student resistance to liberatory curriculum. Paper presented at the Annual Meeting of the American Educational Research Association, April 16-20, Boston.

Latour, B. (1988). The politics of explanation: an alternative. In Steve Woolgar (Ed.) Knowledge and Reflexivity. London: Sage.

Lenntrichia, F. (1983). Criticism and Social Change. Chicago: The University of Chicago Press.

Lewis, M. \& Simon, R. (1986). A discourse not intended for her: learning and teaching within patriarchs. Harvard Educational Review, Vol. 56, No. 4, November.

Lincoln, Y. \& Guba, E. (1986). But is it rigorous? Trustworthiness and authenticity in naturalistic evaluation. In D. D. Williams (Eds.), Naturalistic Evaluation. San Francisco: Jossey-Bass. 
Liston, D. \& Zeichner, K. (1987). Critical pedagogy and teacher education. Journal of Education, $169,3$.

Lorde, A. (1984). The master's tools will never dismantle the master's house. In Sister Outsider. Freedom, CA: The Crossing Press.

Mahony, P. (1988). Women's Studies: an academic model. Women's Studies International Forum, Vol. 11. No. 2., pp. 103-108.

Mazza, K. (1983). Feminist perspectives and the reconceptualization of the disciplines. Paper presented at AERA, April 16-20, Montreal, Canada.

McIntosh, P. (1981). The study of women: implications for reconstructing the liberal arts disciplines. Forum, october.

McIntyre, A. (1981). After Virtue, A Study of Moral Theory. London: Duckworth.

MacKinnon, C. (1988). Feminism, marxism, method and the state. The Signs Reader. Chicago: University of Chicago Press.

Minnich, E., O'Barr, J. \& Rosenfeld, R. (1988). Reconstructing the Academy Chicago: The University of Chicago Press.

Mitchell, J. (1983). Case and situation analysis. Sociological Review, 3 (3).

Mitchell, J. \& Oakley, A. (1986). Introduction. In J. Mitchell \& A. Oakley (Eds.), What is Feminism? New York: Pantheon Press.

Mitchell, J. (1986). Reflections on twenty years of feminism. In J. Mitchell \& A. Oakley (Eds.), What is Feminism? New York: Pantheon Press.

Newsweek, The Homosexual Teacher, Dec. 18, 1978, 91.

Nietzche, F. (1969), On the Genealogy of Morals. New York: Vintage Books. Parlee, M. (1979). Psychology and women. Signs, vol. 5,1 .

Plummer, K. (1975). Sexual Stiama London: Routledge \& Kegan Paul. 
Postman, N. \& Weingartner, C. (1969). Teaching as a Subyersive Activity. New York: Delacorte Press.

Reinhartz, S. (1983). Experiential analysis: a contribution to feminist research. In G. Bowles and R. Duelli Klein (Eds.), Theories of Women studies. London: Routledge \& Kegan Paul.

Rich, A. (1979). On Lies, Secrets and Silences: Selected Prose 1966-1978. New York: W. W. Norton.

Rich, A. (1986). Blood, Bread and Poetry. New York: Norton.

Roland Martin, J. (1986). Refining the educated person: rethinking the significance of gender. Educational Researcher, June/July.

Rose, A. (1972). Human Behavior and Social Processes. London: Routledge \& Kegan Paul.

Rothenburg, P. (1988). Racism and Sexism. New York: St. Martin's Press.

Shaul1, R. (1978). Foreword. In P. Freire, Pedagogy of the oppressed. Middlesex, England: Penquin Books Ltd.,

Shor, I. \& Freire, P. (1987). A Pedagogy for Liberation: Dialogues on Transforming Education. South Hadley, $M A$ : Bergin \& Garvey.

Shor, I. \& Friere, P. (1987). What is the "dialogical method" of teaching? Journal of Education, Vol. 169, No. 3 .

Shrewsbury, C. (1987). What is feminist pedagogy? Women Studies Quarterly XV: $3 \& 4$, Fall/Winter.

Siegel, H. (1988). Educating Reason: Rationality, Critical Thinking, and Education. New York: Routledge.

Spender, D. (1981). Men's Studies Modified: The Impact of Feminism on the Academic Disciplines. Oxford: The Athene Series, Pergamon Press.

Stacey, J. (1988). Can there be a feminist ethnography? Women's Studies International Eorum, Vol. 11, 1.

Stedman, L. \& Smith, M. (1983). Recent reform proposals for American education. Contemporary Education Review, 53 , 85-104. 
Stimpson, C. (1986). Women Studies in the United States. New York: Eord Foundation.

Stoller, P. (1989). The Taste of Ethnographic Things. Philadelphia: University of Pennsylvania Press.

Stumbo, C. (1989). Teachers and teaching. Harvard Educational Review, vol. 59, 1.

Treichler, P. (1986). Teaching feminist theory. In C. Nelson (Ed.), Theory in the Classroom. Urbana: University of Illinois Press.

Walker, R. (1980). The conduct of educational case studies: ethics, theory, and procedures. In W. B. Dockrell and D. Hamilton (Eds.), Rethinking Educational Research. London: Hodder and Stoughton.

Weber, M. (1948). Erom Max Weber: Essays in Sociology. London: Routledge and Kegan Paul.

Welch, S. (1985). Communities of Resistance and Solidarity. New York: Orbis Press.

Westcott, M. (1983). Women's Studies as a strategy for change: between criticism and vision. In G. Bowles \& $R$. Duelli Klein (Eds.) Theories of Women Studies. London: Routledge \& Kegan Paul.

Winchester, I. (1988). Variety of university reforms -superficial and deep. Interchange, 19, 3/4 Fall/Win., 177-187.

Wolin, S. (1988). On the theory and practice of power. In Jonathan Arac (Ed.), After Eoucault: Humanistic Knowledge, Postmodern Challenges. London: Rutgers University Press.

Wood, G., Martin, R. \& Stevens, E. (1988). An Introduction to Teaching: A Question of Commitment. Boston: Allyn and Bacon, Inc.

Woods, P. (1983). Sociology and the School: An Interactionist Viewpoint. London: Routledge \& Kegan Paul.

Woolf, V. (1936). Three Guineas. New York: Harcourt, Brace \& World. 
Young-BreuhI, E. (1988). The education of women as philosophers. In Minnich et al; (Eds.), Reconstructing the Academy Chicago: The University of Chicago Press. 
APPENDIX $A$

TEACHER'S CONTRACT, 1920 
TEACHER'S CONTRACT 1923

This is an agreement between Miss the Board of Education of the , teacher, and whereby Miss agrees to teach for a period of eight months, beginning sept. 1, 1923. The Board of Education agrees to pay Miss __ the sum of per month.

Miss agrees:

1. Not to get married. This contract becomes null and void immediately if the teacher marries.

2. Not to keep company with men.

3. To be home between the hours of $8: 00$ P.M. and 6:00 A.M. unless in attendance at a school function.

4. Not to loiter downtown in an ice cream stores.

5. Not to leave town at any time without the permission of the chairman of the Board of Trustees.

6. Not to smoke cigarettes. The contract becomes null and void immediately if the teacher is found smoking.

7. Not to drink beer, wine, or whiskey. This contract becomes null and void immediately if the teacher is found drinking beer, wine, or whiskey.

8. Not to ride in a carriage or automobile with any man except her brother or father.

9. Not to dress in bright colors.

10. Not to dye her hair.

11. To wear at least two petticoats.

12. Not to wear dresses more than two inches above the ankles.

13. To keep the schoolroom clean.

a) to sweep the classroom floor at least twice daily

b) to scrub the classroom floor at least once weekly with hot water and soap.

c) to clean the blackboard at least once daily

d) to start the fire at 7:00 A.M. so the room will be warm by 8:00 A.M. When the children arrive.

14. Not to use face powder, mascara, or paint the lips.

(Michael Apple, 1985) 
APPENDIX B

COURSE SYLLABI 
WS 1824: Introduction to Women's Studies

Fal1 1989

Office Hours: $3-4 \mathrm{MW}$ and by appointment

I listen to the old brag of my heart. I am. I am. I am.

$$
\text { -- Sylvia Plath }
$$

carse description:

women's studies is an interdisciplinary program which places

- women's lives and experience at the center of intellectual

and creative inquiry. This introduction to a concentration in women's studies will ask you to re-think many cultural, racial and economic assumptions upon which we base our lives by making wom en's experience its primary focus and by reimagining women's and men's lives in reltion to cultural concepts of gender.

Requirements:

To read perceptively, sensitively, imaginitively, and intelligent1y. To exhibit this skill in discussion.

This will be a seminar class, and so calls for active student participation. We will be reading extensively and it is your response to the material -- your questions, your ideas, your delight or dismay -- that will make this a good class.

Grading:

Journals -- to be turned in three times $60 \%$

750 word essay $20 \%$

Class participation/Final exam 20\%

* Please note that all work for the class must be completed and

turned in in order to receive a passing grade. Students are

responsible for the Virginia Tech Honor Code which covers all

aspects of this course.

Texts :

Women's Realities, Women's Choices: An Introduction to Women's

Studies, Hunter college Women's Studies Collective

Don't Bet on the Prince: Contemporary Feminist Fairy rales

in North America and England, ed. Zipes

Cassandra, Florence Nightengale

Sula, Toni Morrison

Woman Warrior, Maxine Hong Kingston

Kinko $\frac{\text { s packet }}{}$ 


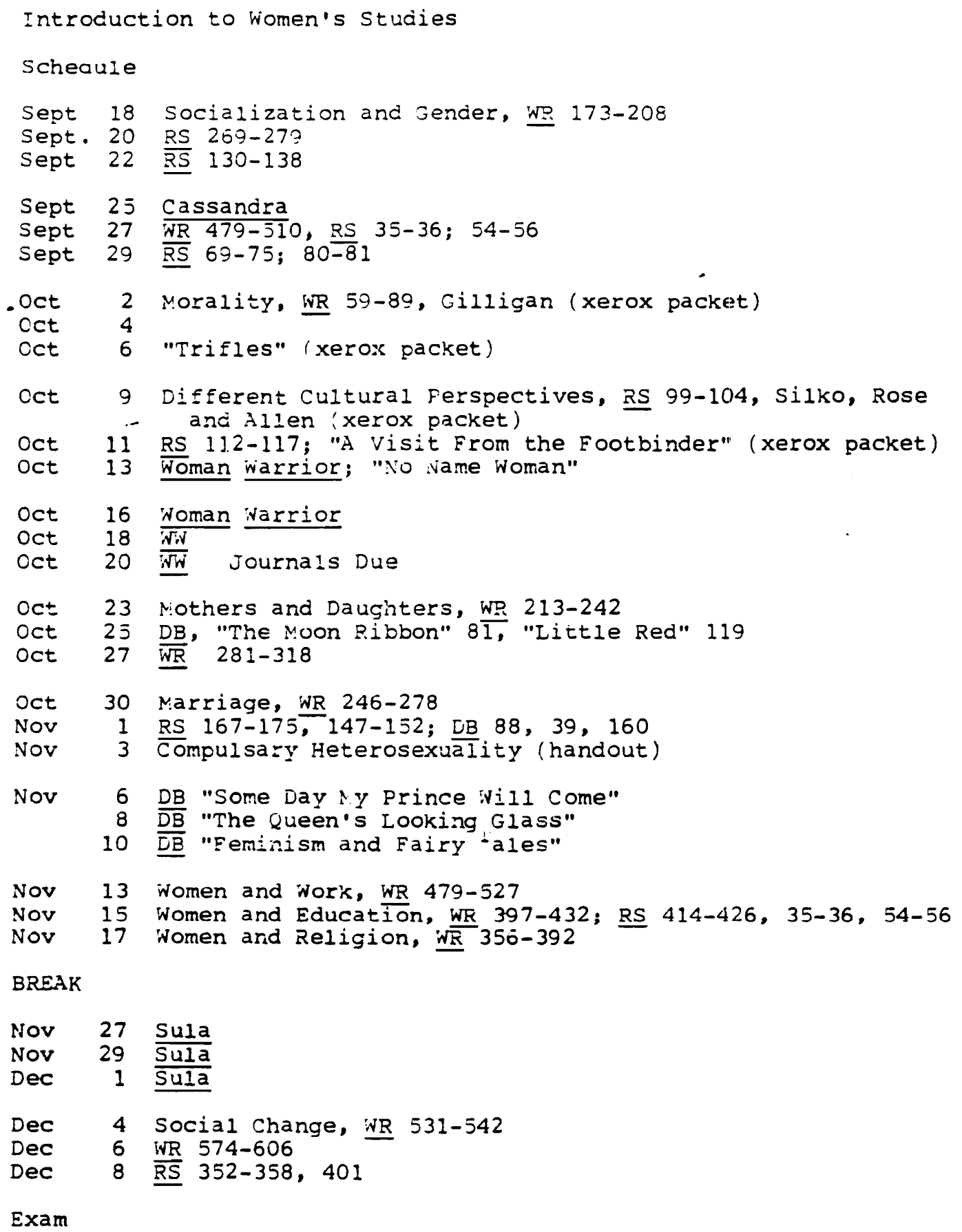




\author{
$=\operatorname{sem} 2 \pi 1=2$ " Eory \\ Wimen $\Xi$ studi $\equiv$ irograil
}

Ortide Hours: T- T j::5-4:30 and oy $a=z=i n t m e n t$

TEXT:.

THE SIGNS READER, eQ. ADE I (S)

FEMINIST THEORY: A GRITIQUE UF IDEOLCE. ea. Keonane (FT)

THIS BRIDGE CALLED MY BACK: WRITINGS E RADICAL WOMEN OF COLOR, aus. Moraga and Anzalaua ( $B$ )

NEW FRENCH FEMINISMS, ed. Marks and dej;itimon (FF,

HAE CIHAL ICE HND IHE BLADE. KlanE ELELEr

EEY OND POWER. MaIILY FrenciT (recommerias: text)

UUURSE DESCREIIION WI. REQUIREMENTS:

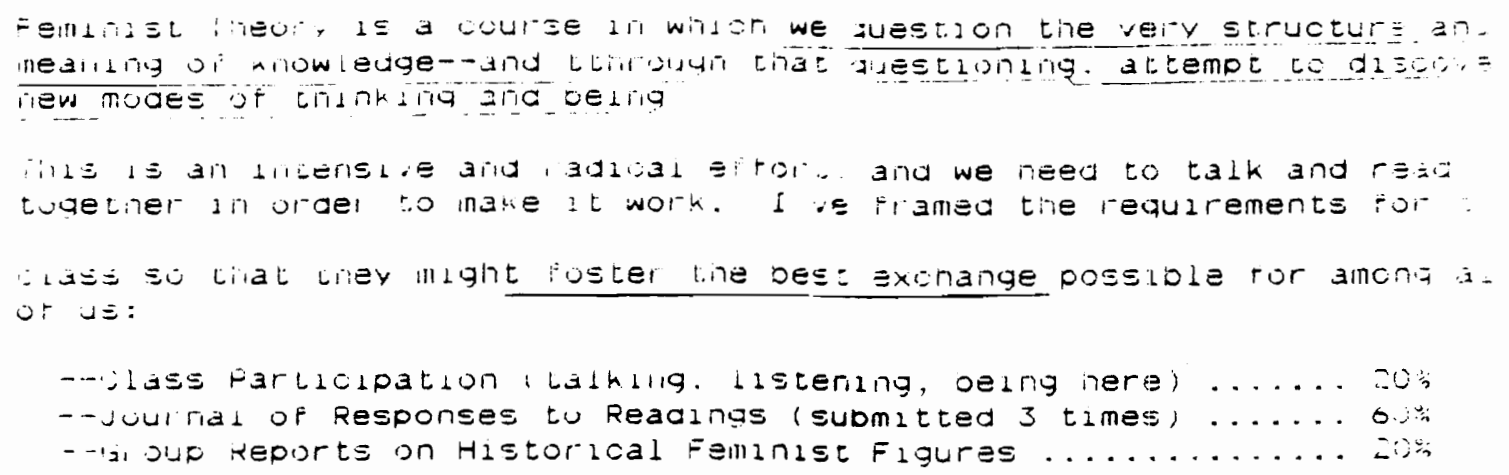

TENTATIVE SCHEDULE:

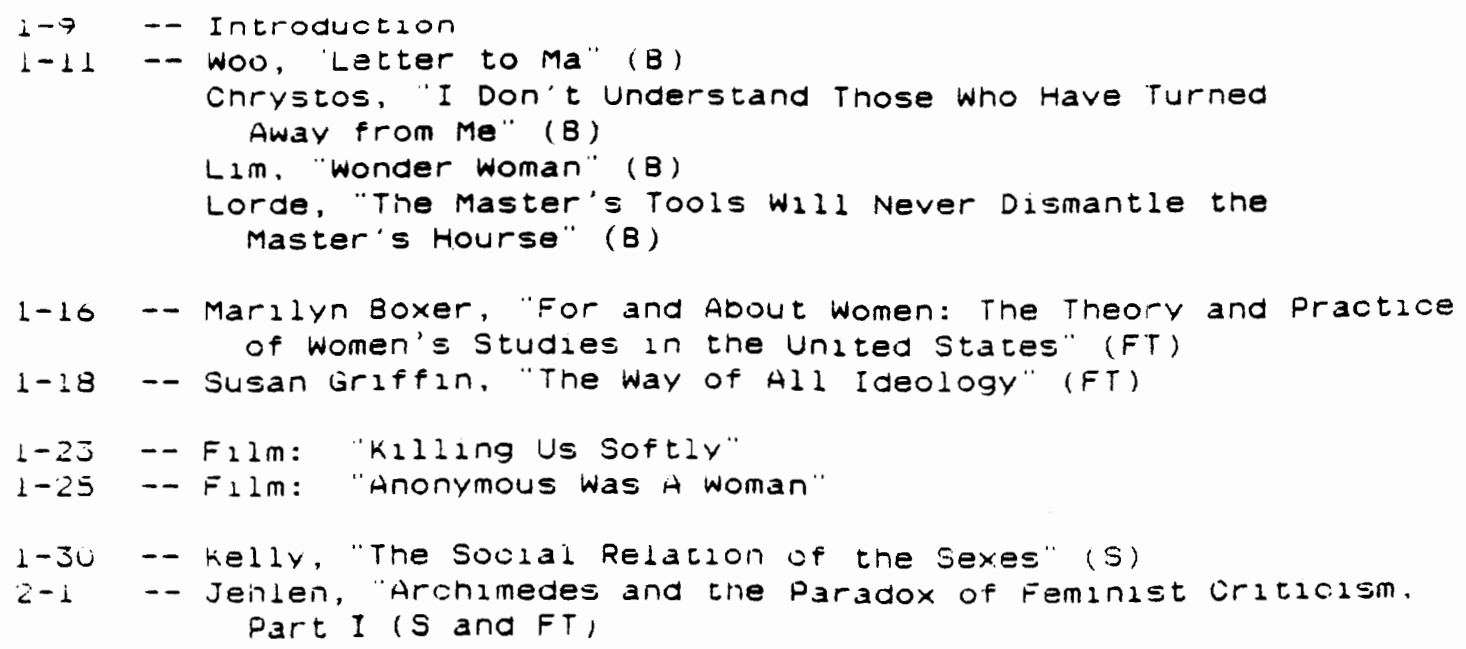


Feminist Theory: Tentative Schedule of Readings

I've arranged this syllabus so that we can have a heavy dose of readings at the beginning. and a somewhat looser schedule near the end of the semester both for Group Reports and for returning to those subjects and readings that we want to discuss further. We can change--expand readings and contexts, or move to other subjects--whenever that seems best.

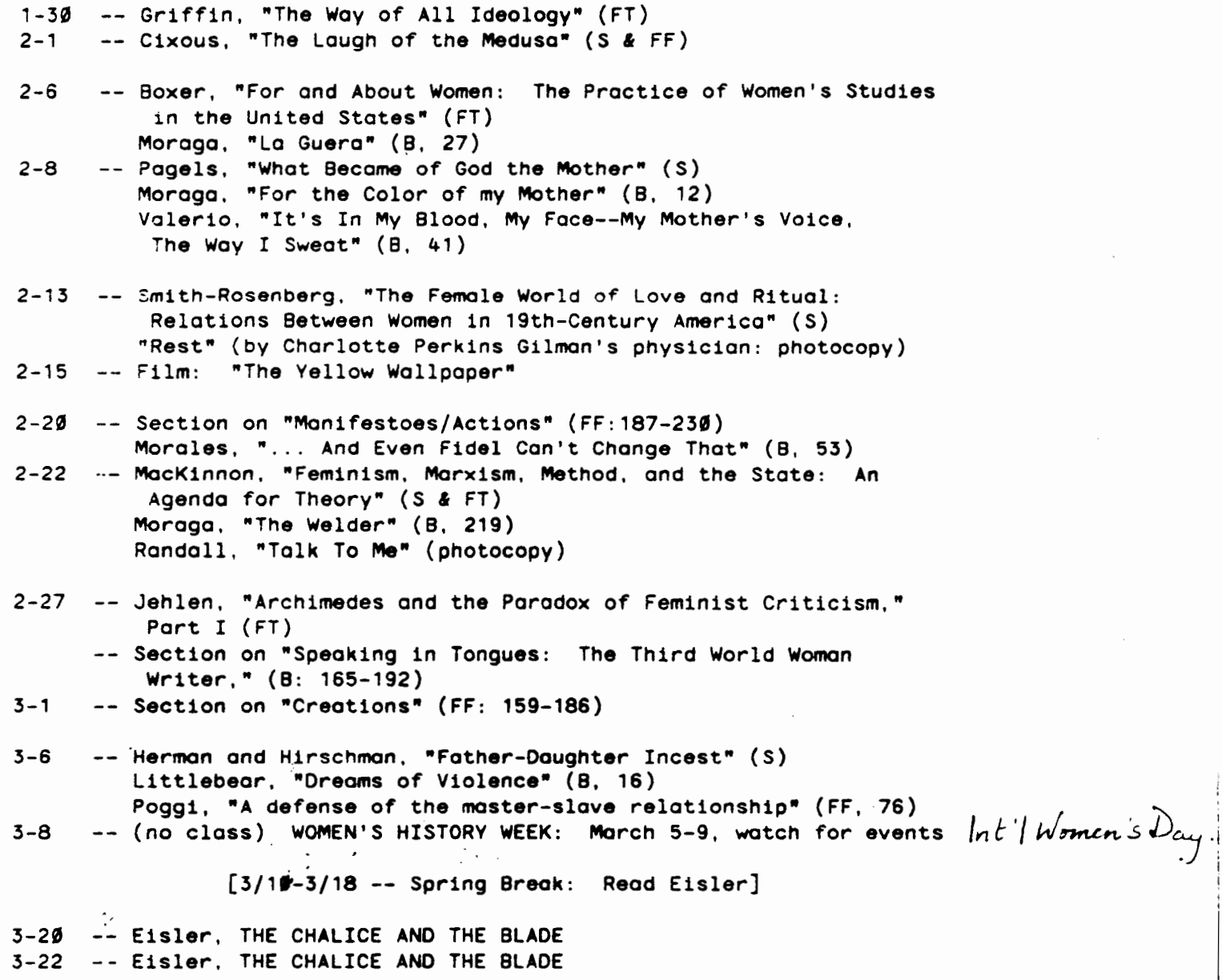


Southeast Women's Studies Association Conference:

March 23, 24, 25 -- Roanoke College, Salem, Virginia

Keynote on Friday night -- Elien Goodmon

March 28 -- Helen Caldicott speaks in CEC auditorium

March $26 / 27-3001$ 's script reading in Theater Arts

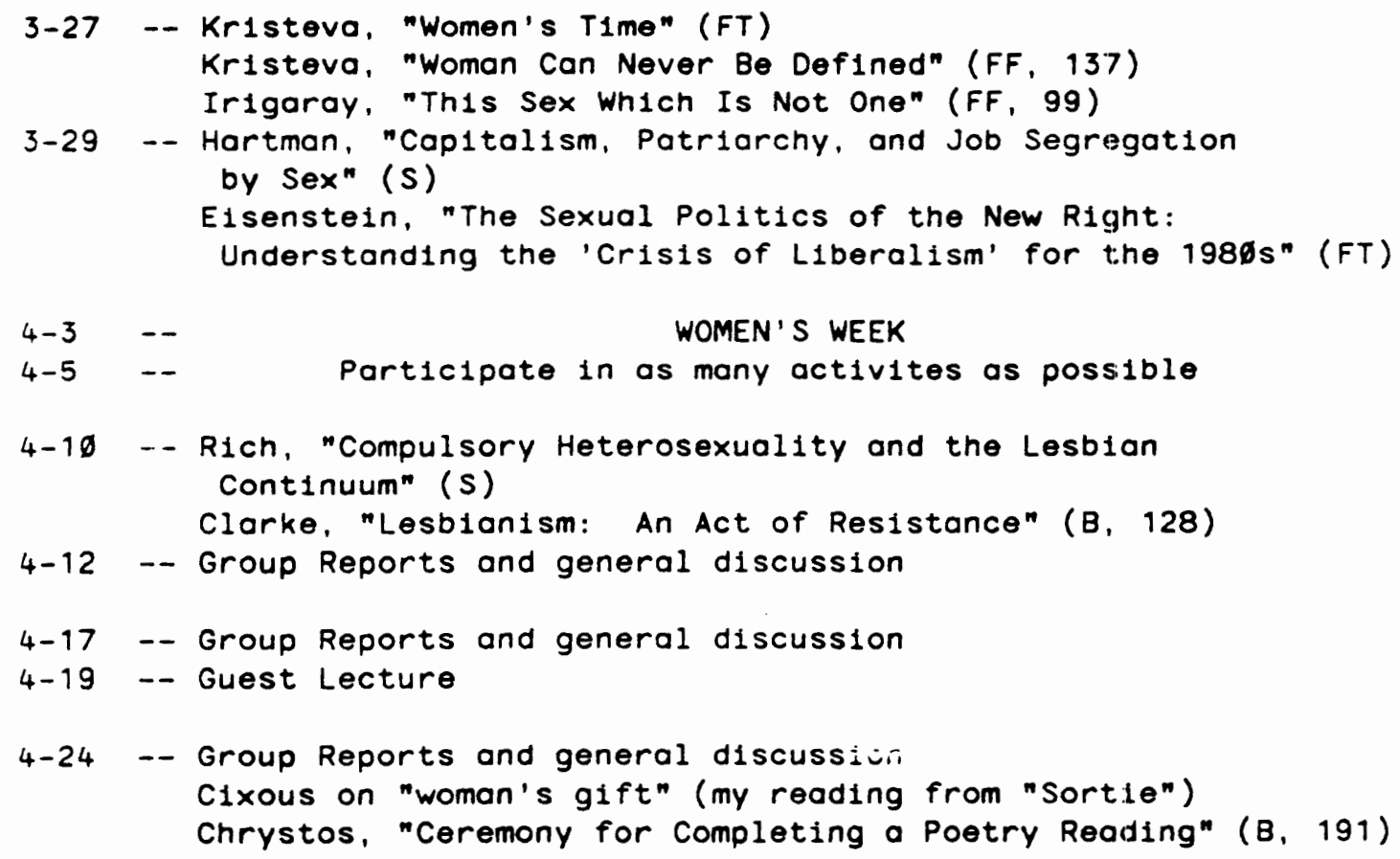


Women Studies 422

WOMEN AND REPRESENTATION

T Th $11-12: 15$

Autumn 1989

Prerequisite: Introduction to Women Studies

Course Description:

The seminar will examine issues surrourding the representation of women in Western culture. Four methods of inquiry strurture our discussion. First, we'll consider the representation of the female mularto in American society to see what this figure can show us about representation in general. Second, we'll examine major essays that emerged from an intense feminist inquiry into the place of woman in cinematic representation. Then, we will read essays by two major poststructuralist theorists to understand what they ran tell us about the place of the feminine and the maternal in our culture. Finally, we'll read four novels to see on what grounds each novelist configures the representation of women and also to discover how feminist theories of representation can inform our reading. The aim of the course is to learn some contemporary ways of questioning and responding to the representation of women. Behind this aim lies the major political question of how feminism engages and disengages other pow-structuralist an post-modern theories of representation.

A film series sponsored by the Women's Studies Program, the Department of English, the Department of Communications, the Learning Resource Center and the Media Center at Newman Library is being shown in support of this course.

Texts:

Larsen, Quicksand and Passing

Penley, Feminism and Film Theory

Lorde, Sister Outsider

Irigary, This Sex Which is Not One

Kristeva, Desire in Language

Todd, Feminist Literary History

Richardson, Pamela

Haywood, Anti-Pamela (Xerox on Reserve)

Morrison, Beloved

Acker, Blood and Guts in High School

\section{Self-Representation: The Image of the Female Mulatto}

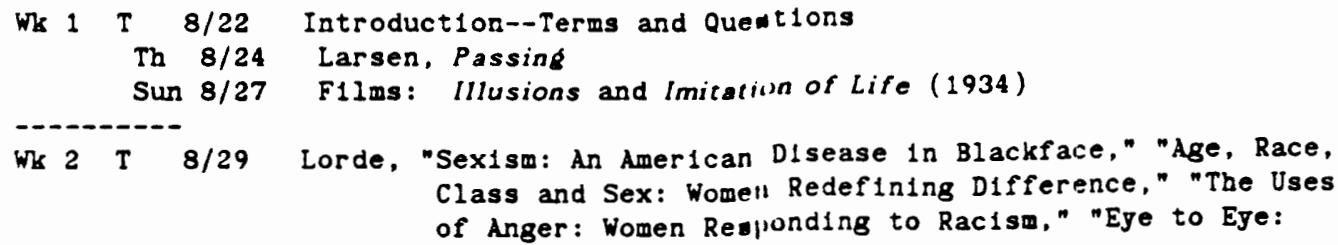


Black Women, Hatred and Anger," "The Master's Tools W11l Never Dismantle the Master's Housen

\title{
II. Feminist Film Theory and Criticism
}

\author{
Th 8/31 Mulvey, "Visual Pleasure and Narrative Cinema" in Penley. \\ Att1le and Blackwood, "Black Women and Representation" on \\ reserve. \\ Sun 9/3 F11m: Imitation of Life (1959) \\ Wh $3 \mathrm{~T} 9 / 5$ Mulvey, "Afterthoughts on 'visual Pleasure and Narrative \\ Cinema' Inspired by Duel in the Sun" in Penleg. \\ in $9 / 7$ Bergstrom, "Alternation, Segmentation, Hypnosis: Interview with \\ Raymond Bellour--An Excerpt" in Penley. \\ Sun 9/10 F11m: The Revolt of Mamie Stover \\ Wh 4 T $9 / 12$ Cook and Johnston, "The Place of Woman in the Cinema of \\ Raoul Walsh" in Penley. \\ Th 9/14 Cook, "Approaching the Work of Dorothy Arzner" in Penley. \\ Johnston, "Dorothy Arzner: Critlcal Strategies" in Penley. \\ Sun 9/17 Film: Dance, Girl, Dance \\ Wk 5 T $9 / 19$ Doane, "Woman's Stake: Filming the Female Body" in Penley: \\ Th $9 / 21$ No class (Conference travel) \\ Sun 9/24 F11m: The Man Who Envied Women
}

III. Irigary and Kristeva: Theories of the Feminine and of the Maternal

Wh 6 T 9/26 Irigary, "The Looking Glass from the Other Side"

Th 9/28 Irigary, "This Sex Which Is Not One," "Psychoanalytic Theory: Another Look"

Wk $7 \mathrm{~T} \quad 10 / 3$ Irigary, "The Power of Discourse and the Subordination of the Feminlne," "Cos1 Fan Tutt1"

Th 10/5 Irigary, "Questions, "When Our L1ps Speak Together"

Wk 8 T 10/10 Kristeva, "Stabat Mater" on Reserve

Th 10/12 Kristeva, "Motherhood According to Bellinl"

Wh $9 \mathrm{~T} 10 / 17 \mathrm{Kr} 1$ steva, "Word, D1alogue and Novel"

Th $10 / 19 \mathrm{Kr}$ isteva, "How Does One Speak to Literature?"

Wh $10 \mathrm{~T}$ 10/24 Todd, Feminist Literary History

Th $10 / 26$ Review

IV. Four Novels

Wh $11 \mathrm{~T}$ 10/31 Richardson, Pamela

Th 11/2 Richardson, Pamela

- - -

Wh 12 I $11 / 7$ Haywood, Anti-Pamela

Th 11/9 Haywood, Anti-Pamela 


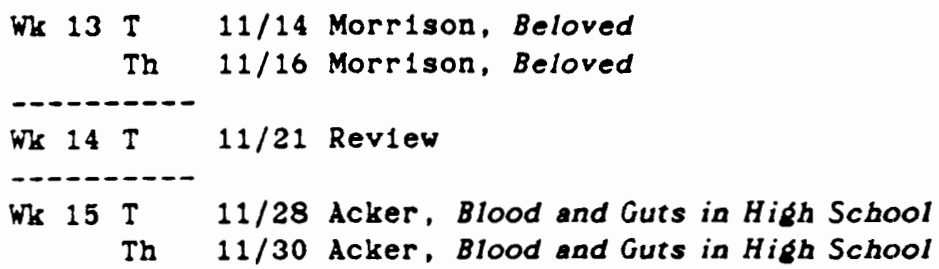

\section{Grading:}

Representation Project Woman Artist Project Writings on Readings

$25 \%$
$50 \% \quad 25 \%$

Course Requirements:

1) Participation in class discussion is essential to understanding the course material. Not attending class will be detrimental to your grade.

2) Attendance at the Sunday evening film series is required.

\section{Course Policies:}

1) Late papers will not be accepted except by prior arrangement with the instructor.

2) This course adheres to the Honors Code. 


\section{WOMEN'S STUDIES FILM SERIES}

\section{Sunday, August 27 \\ ILLUSIONS (1982) Directed by Julie Dash. 34 mins. Color}

Black filmmaker Julie Dash re-creates Hollywood in the 1940 s in a film which exposes the troubled racial undercurrents of classic Hollywood film production. Mignon Dupreee, a black woman studio executive who appears to be white comes into conflict with Ester Jeeter, a black singer whose voice is dubbed for a white Hollywood star. IMITATION OF LIFE (1934) Directed by John Stahl. 106 mins. B\&W

A white widow gains economic security when she and her black maid manufacture pancake batter. In addition to their economic links, the two women share troubled relationships with their daughters which center on the maid's light-skinned daughter who wants to pass for white. Stars Claudette Colbert.

\section{Sunday, September 3}

\section{IMITATION OF LIFE (1959) Directed bv Douglas Sirk. 120 mins. Color}

In Sirk's stylistically saturated version of the story, Lana Turner and her black maid join forces to promote Turner's carrer as a Broadway actress while their daughters struggle to find what's real in the illusory world Sirk creates for them. Sirk's configuration of race, gender and class as they affect the lives of the four wornen differs in intriguing wavs than Stahl's version of the story.

\section{Sunday, September 10}

\section{REVOLT OF MAMIE STOVER (1956) Direcrted by Raoul Walsh. 95 mins. B\&W}

This film served as the focus of important feminist critiques of the place of Woman in classic Hollywood cinema. ;ane Russell, as Mamie Stover, gets rich, but loses her man, or perhaps her economic independence proved too troublesome for him.

\section{Sunday, September 17}

DANCE, GIRL, DANCE (1940) Directed by Dorothy Arzner. 89 mins. B\&W

Arzner, the only woman director during the classic penod of Hollywood cinema, waited thirty years for her work to find its audience. Relegated to obscurity by auturist film criticism of the post-World War Il period, Arzner's films required the theoretical positions developed by feminist film criticism of the early 1970 s. Today we can see her work as a powerful critique of the representational conventions of classic cinema, particularly in regard to the place of women within those conventions. Maureen $O$ Hara and Lucille Ball star as struggling dancers whose identities are crucially shaped by the images they seem required to make of themselves.

\section{Sunday, September 24}

THE MAN WHO ENVIED WOMEN (1985) Directed by Yvonne Rainier. $125 \mathrm{mins}$. Color/B\&W A comic masterpiece of contemporary feminist cinema, Rainier's film holds no punches in its depiction of Jack Deller, film theorist and self-satisfied womanizer, who confesses he "knows almost too much about women." Rainier has much to say, as well, about the sometimes hilarious pretentions of feminist theory. She gives us, almost as a bonus, new ways of seeing some of our cherished oppositions: those between the sexes, theory and practice, the conscious and unconscious, intellect and emotion, and between personal and global concerns. 
APPENDIX C

FACULTY AND STUDENT CONSENT FORMS 
FACULTY CONSENT FORM

This is an invitation to you to participate in a study of Women Studies professors' perspectives and experiences as they teach Women Studies classes and participate in the Women Studies community on campus at Virginia Tech. This research, which I am conducting as my doctoral dissertation, consista of participant observations in Women Studies classrooms as well as interviews with the faculty and studenta. However, I am also interested in learning something about how the Women Studies department fits into the university administratively. To this end, I am conducting interviews vith the past and present co-ordinators of Women Studies programs.

If you decide to participate in the research I will ask you to spare your time for a number (probably 3-4) of interviewa over the courae of the academic year 1989-1990. Alao I would like to be a participant observer in the classroom during the Women Studies course you teach in the current academic year. Anything you say in class or during an interview -- indeed all information collected for thia project will remain confidential. You vill be invited to reviev all trangcripts and any writen documents [dissertation, papers] based on the data collected, should you wiah to do so. At this juncture you will be free to delete or add to the transcribed data, or to make a written response on your own behalf to the researcher. As principal investigator of the project only I vill have access to data containing information that would identify individuals. In the disertation, and any publications based on these data, the identities of all participants will be masked in such a way that quoted comments cannot be attributed to particular individuals. However, though I vill do my utmost to secure confidentiality, given the small number of professors involved in women Studies courses on campus it may be difficult to mask your identity вuccessfully.

Your decision regarding participation in this research will not affect your status at the university in any way, and you can discontinue participation at any time without prejudice. If you wish to do so you may contact me by letter or by phonecall using the information provided below. You may also inform me of your decision to discontinue by contacting my major profeseor, Dr. Rosary Lalik, at 231-5558. However, your contribution is very important if the results of this study are to be meaningful. 
If you have questions regarding any aspect of this study, please contact me:

Anne Phelan Curriculum and Instruction Division 300 War Memorial Hall 231-5558 (Office) 552-3047 (Home)

Your signature below indicatea that you have read the information above and have decided to participate. You will be offered a copy of this form to keep.

Signature

Principal Inveatigator's Signature 


\section{STUDENT CONSENT FORM}

This is an invitation to you to participate in a study of Women Studies professors' perspectives and experienceg as they teach Women Studies classes and participate in the Women Studies community on campus. This research, which I am conducting as my doctoral dissertation, consists of participant observations in Women Studies clasarooms as vell as intervievs with the faculty and studenta. However, I am also interested in learning something about how the Women Studiea department fita into the univeraity adminiatratively. To this end, I am conducting intervievs with the past and present co-ordinatora of Women Studies programs.

If you decide to participate in the research I will ask you to spare your time for a number (probably 1-2) of interviews over the course of the academic year 1989-1990. Also I would like to be a participant observer in the clasaroom during the Women Studieg courge you are attending in the current academic year. Anything you say in clase or during an interview -indeed all information collected for thia project will remain confidential. You will be invited to reviev all transcripta and any vritten documenta [dissertation, papers] based on the data collected, should you wish to do so. At this juncture you vill be free to delete or add to the transcribed data, or to make a written response on your own behalf to the researcher. As principal invertigator of the project only I will have access to data containing information that would identify individuala. In the diseertation, and any publications based on these data, the identities of all participanta will be masked in auch a way that quoted commenta cannot be attributed to particular individuals. However, though I will do my utmost to secure confidentiality, given the amall number of atudents involved in some Women Studies couraea on campus it may be difficult to mask your identity aucceesully.

Your deciaion regarding perticipation in this research $\mathbf{1} 11$ not affect your atatue at the university in any way, and you can discontinue participation at any time without prejudice. If you wish to do so you may write or call me using the information provided below. You may alao inform me of your deciaion to discontinue by contacting my major professor, Dr. Rosary Lalik, at 231-5558. However, your contribution la very important if the reaults of this study are to be meaningful. 
If you have quegtions regarding any aspect of this study, please contact me:

Anne Phelan Curriculum and Instruction Diviaion 300 War Memorial Hall 231-5558 (Office) 552-3047 (Home)

Your signature below indicatea that you have read the information above and have decided to participate. You will be offered a copy of this form to keep.

Signature

Date

Principal Investigator's Signature 
APPENDIX D

SOCIAL PROCESSES AND MEANING:

SYMBOLIC INTERACTIONISM

341 
Social Processes and Meaning

The case studies in this research are situated within a theoretical framework that focuses upon social processes and the meanings that individuals attribute to social situations. The orientation is named symbolic Interactionism.

\section{Symbolic Interactionism}

Woods (1983) writes that the notion of "people as constructors of their own actions and meanings" is central to symbolic interactionism. People live in a physical world, but individuals may ascribe different "meanings" to objects in that world. For one academic feminist, perhaps, the world of a specific university is an oppressive institution; hence when invited to present a paper in this university the individual may decide to refuse the invitation or may present the paper with much apathy. For another academic feminist the same university is a liberating arena; the opportunity to present a paper in this institution is met with much enthusiasm. Objects are symbolic -- they indicate certain meanings. The first premise of symbolic interactionism is that human beings act towards objects/persons/events on the basis of the meanings that those things have for them (Blumer, 1969). In the context of this research it would be unfortunate to attribute a single "feminist" identity to all three academics. To do so would be to ignore the influence 
of individual meanings on behavior if favor of factors alleged to produce behaviors.

The second premise of symbolic interactionism is that meaning arises out of interaction between individuals and groups. Blumer (1969) writes that "the meaning of a thing for a person grows out of the ways in which other people act toward the person with regard to the thing. Their actions operate to define the thing for the person."(4) I would add that these "actions" have also been informed by the initial meanings that the individual attributed to the thing. The process of meaning-making is cyclical and meanings are therefore social products. The interaction between the participants in the study with other academic feminists, and colleagues, became an important focus of the research in order to understand the meanings that the participants ascribe to their activities and lives. It became clear through data analysis [specifically interviews] that certain other colleagues, for example, the Women Studies coordinator, were significant in the lives of the academic feminists; interviews were arranged with those colleagues.

The use of meanings that are socially constructed are further interpreted by the individual, revised and used to guide subsequent action. This then is the third premise of symbolic interactionism. The individual is seen as an agent who "selects, checks, suspends, regroups, and transforms the meanings in the light of the situation in which $s /$ he is 
placed and the direction of his/her action" (Blumer, 1969:

$5)$. Woods (1983) refers to the importance of

situation-definition for the actor. A given definition of a situation provides a key to interpretation and aids the construction of an individual's own action. Key definitions can become fixed, situations become structured and set, and actions patterns appear. Such patterns of action or habituated ways are "roles"; roles that are actively created/contrived in keeping with the individual's definition of the situation. Plummer (1975) describes how roles are "taken", "made", and "identified with"...

The interactionist starts out from the notion of [persons] busily constructing images of how they expect others to act in given positions (role-taking), evolving notions of how they themselves expect to act in a given position (role-making), and also imaginatively viewing themselves as they like to think of themselves being and acting in a given position (role identity).

$$
\text { (Plummer, 1975: 18) }
$$

Plummer's description had interesting implications for this research. Teachers as "transformative intellectual" appeared constrained in their work as they took on roles that they saw as being expected of them. Academic feminists, for example, learned to identify "acceptable" scholarship that would lead to publications and ultimately tenure; acceptable scholarship seemed to, however, exclude any transformative agenda. Moreover, while identifying with the role of "transformative 
intellectual" teachers were often seen to be acting otherwise.

It seems that, at all times. the relationship between the individual and his/her social milieu is a dialectical one, according to the interactionist view (Woods, 1983).

Society is a dialectic phenomenon in that it is a human product and nothing but a human product, that yet continuously acts back upon its producer. Society is a product of [humans]. It has no other being except that which is bestowed upon it by human activity and consciousness. There can be no social reality apart from [humans]. Yet it may also be stated that [humans] are also a product of society. Every individual biography is an episode within the history of society, which both precedes and survives it... What is more, it is within society, and within social processes that the individual becomes a person, that [she] he attains and holds onto an identity and that [she] he carries out various projects that constitute his [her] life.

(Berger, 1969:3)

The paradox, of course, is the freedom and constraint that exists for the individual whose actions are rarely original, but at the same time not totally determined by culture or structure. Rose (1972) suggests that there is tremendous possibility for the individual given an interactionist framework. The opportunity to create and interpret meanings provides the possibility of innovation and transformation.

Berlak and Berlak (1981) express it as:

The process we call in our language of entities, "mind", is what enables homo sapiens to both adapt to the environment and 
alter it in order to cope with problems

confronting the species.

(Berlak and Berlak, 1981)

The interactionist perspective was highly consistent with the orientation of this research -- the possibilities of humans to transform their social world through processes of deconstruction and reconstruction. Society, as Berger (1969) has informed us, has been constructed by human activity and consciousness; society can be reconstructed with the development of new forms of consciousness. The Neo-marxist and feminist literature suggests a struggle to develop a political consciousness in students. Human activity that is guided by such a political consciousness may lead to a more democratic social "reality". 
APPENDIX E

DATA ANALYSIS: MEMOS AND VISUAL DISPLAYS 


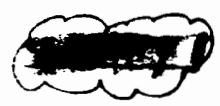

\section{arimers}

Step?. How Authority is spoken about by students.

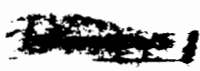

Nikki: ps: teacher-student relationship - simederts expectations - Mirritating, $A-$
not radiesi onsugn, soft-viced - prior experience

$\therefore \quad p 6$. It's not her that ivritates you - its her questions

$y^{\prime} p^{7}$. She wants an answer printe - time issue

$\therefore p 7$ - someone to sit + chill with...! role model? someonce who has an $\bar{A}-$ opinim on everything

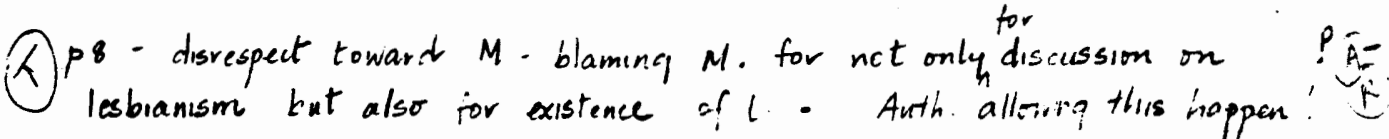
pil- everyone starts chatting when Susan's making her concluding? remarks - is deference in the "suthority" of the tacher?! is $p^{\prime \prime}$ - Assiquments - stuckents skim wicwr. - $\Rightarrow$ negotation of ass qniniols rather than top-down morlel. Students make own decisions ridit what is worthwhile?

p12 "She really got upset at me - dac to incomplete reading of A Kingstire book.

p12: Tournal-ste wants it like $3 i 4 \ldots$ a iveek

- lack of flexibility in requivements fo journal

p16- Nikkis invitaticin to class + Susan to view movie at her place A- laxity - "iansehrily atmosphere"-

p17.- ensey eacloother but not really try'sy to go out of then way it 
349

Step 2: Categorizing responses on theme 'Authority'

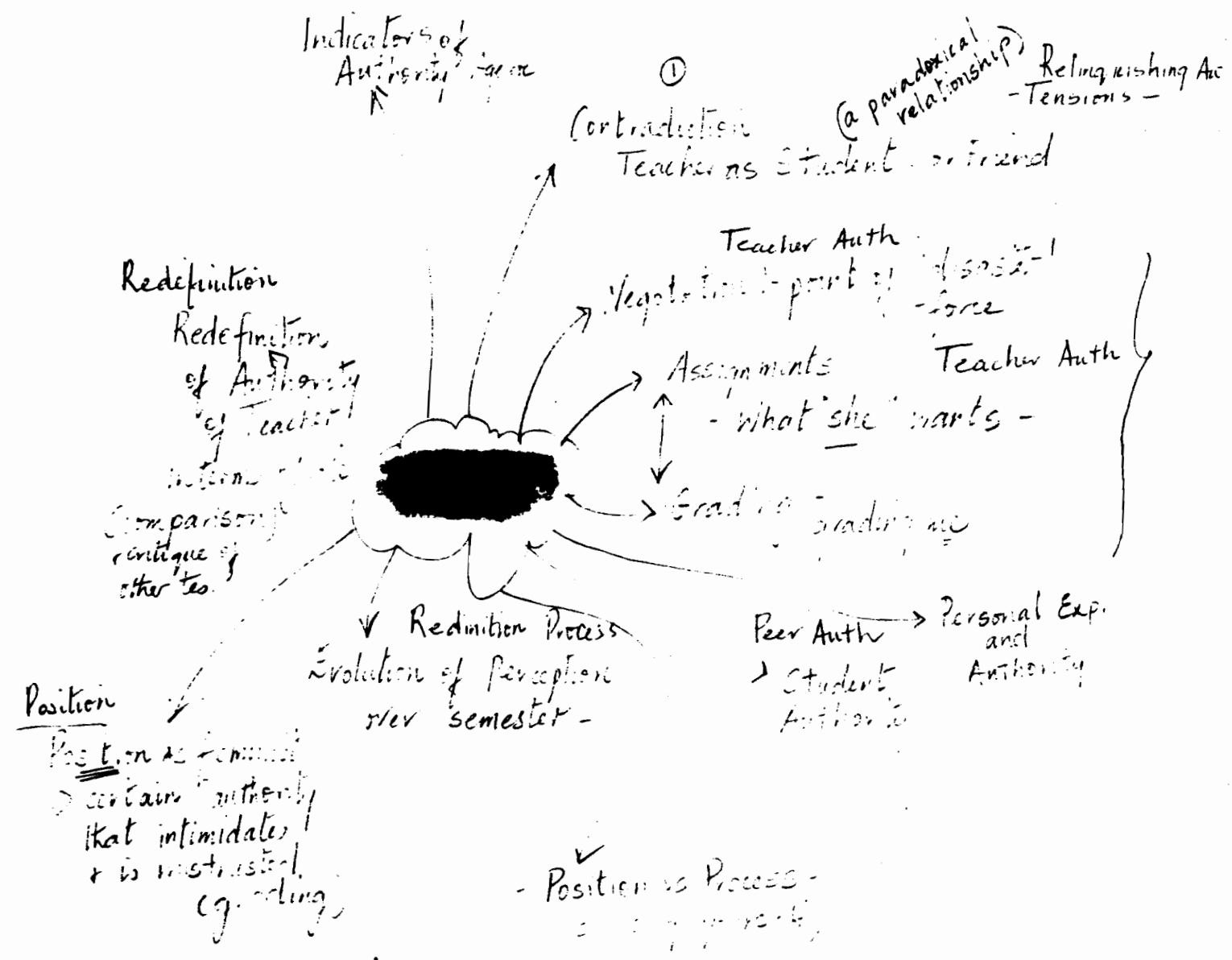

Step $3:-$ Work thru. fieldricte, and journals to check categories: above, reformulate add (generally) 


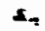

:

350

Step : Additional categories -

Relingushing Authority

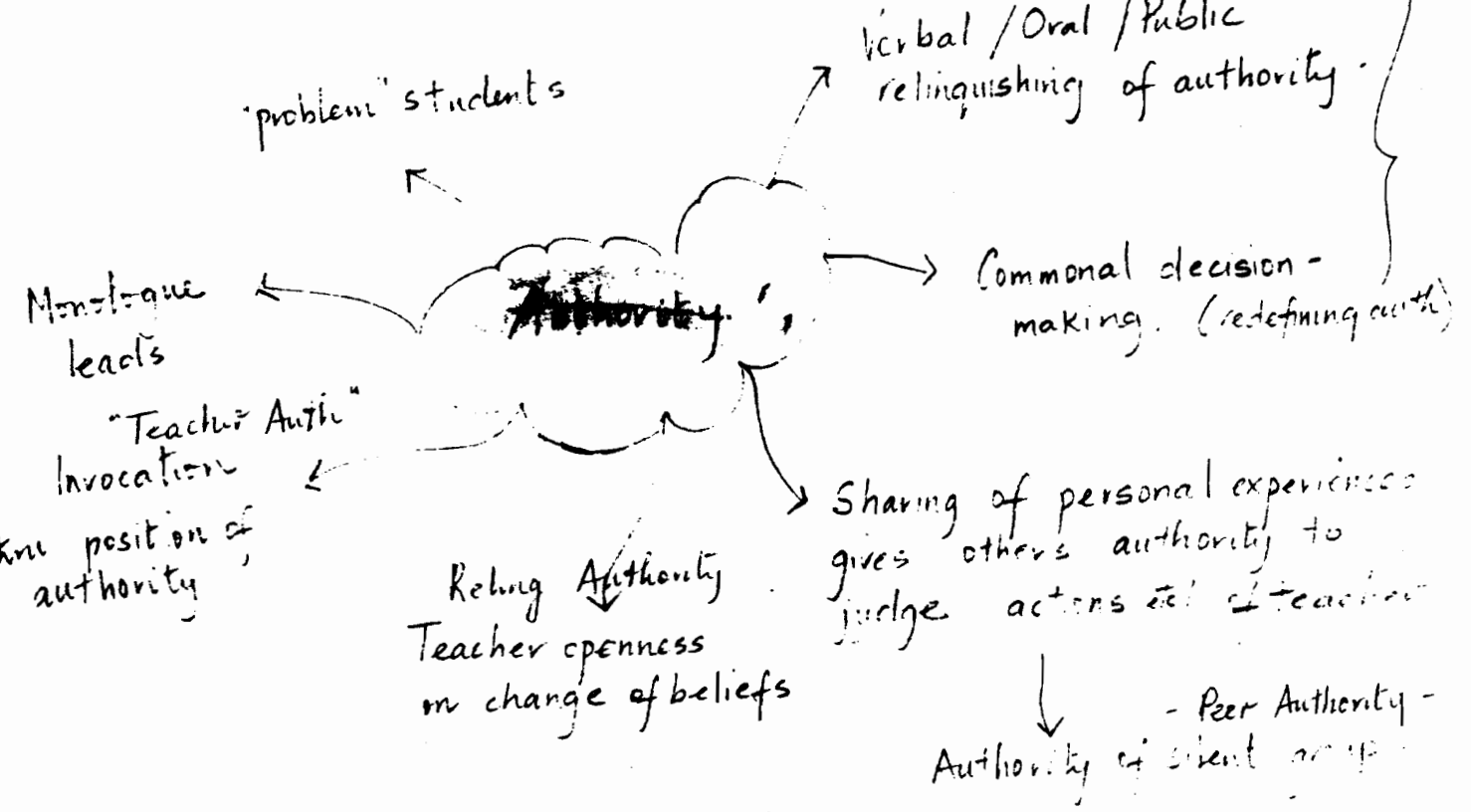

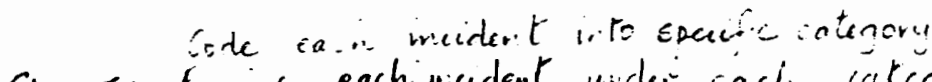

Step 5:- Kaninc each wicedent wirker cach catecaor.

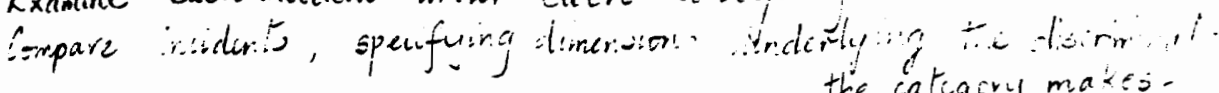
the cakagry makes-

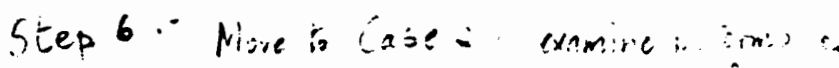
enierging firm Cose!

Step 7 . Nive ti Case 3 .

ririte

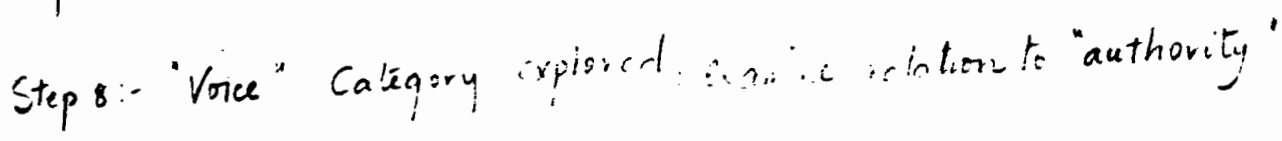


351

(1) Teacher/Friend: Contradiation?"1

Niek. If In answer to my? regarding her relatimship to $M$. nikki sugqeats that the wired be a good peioton io inere

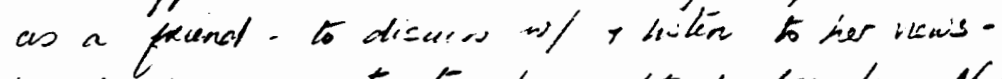
$\therefore$ If giver upseterily she might be priench. Niktc

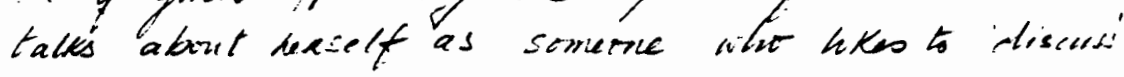

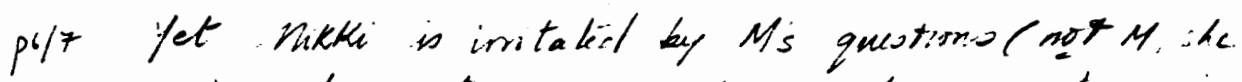
says) - she narts an anosti peonto - no home gien

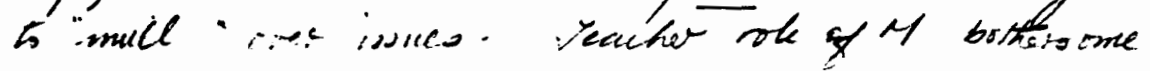

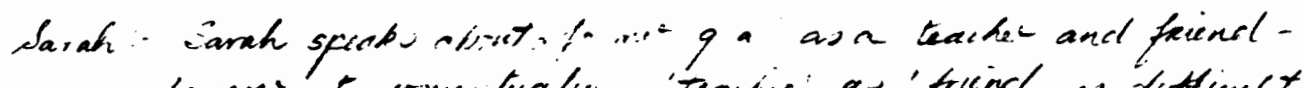

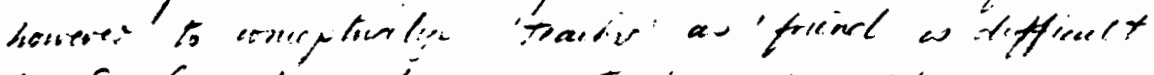

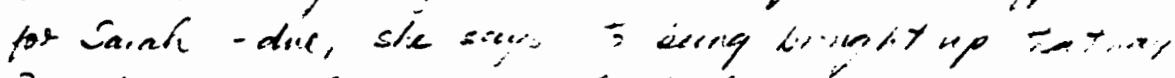

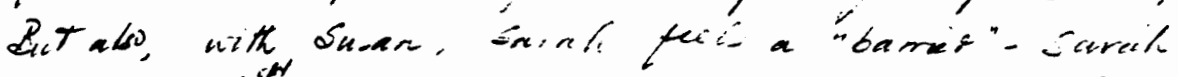

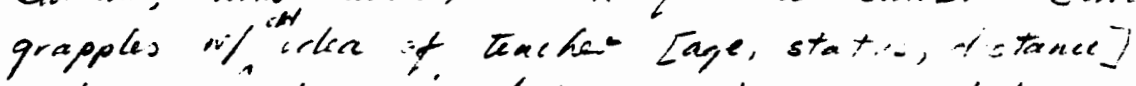
-ard "new" welen of teril:-' now bency presented. Ele experes it in tain of ribures - distance.

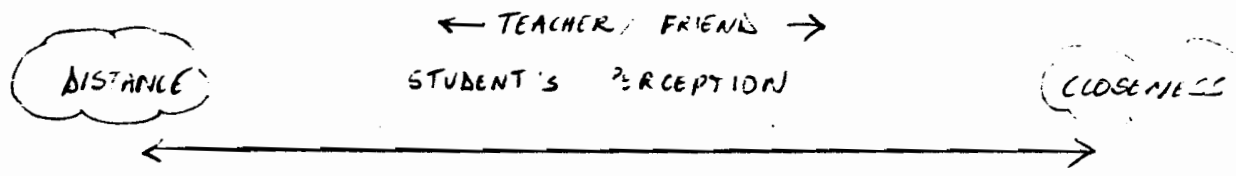

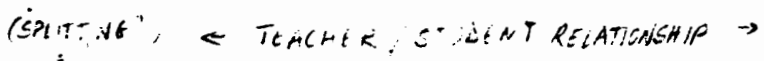

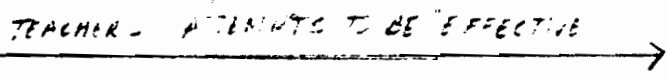


Fither page:

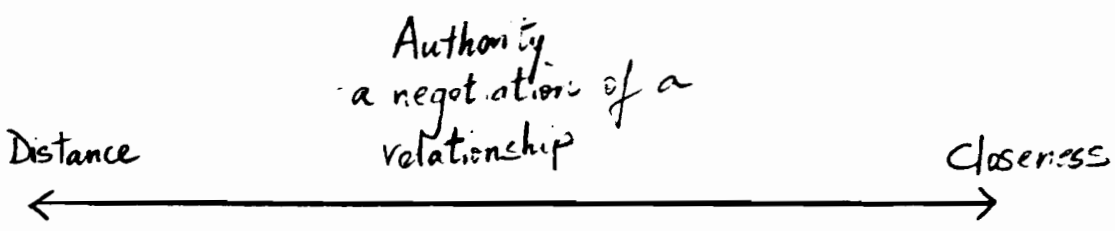

1. Answers pronto

T.llpset at inismplete ass

Someore tosit + dill with

T. requirementó

* Pleasing teachir

- Intimidated

[T. coming on strong]

Grading me

invitation to view mevie

6 Keeping notion of imstracion

7. Should force is to read

9 teacher int friend

not like a veal person

W/ Susan you realleghovea
frerd.

barrier, distant feeling

10. just because shi's a teaclor gets anniryed w/ people

Teacheris assurance

Trist

Feeling connection

doesn't take sub-supa.d pos

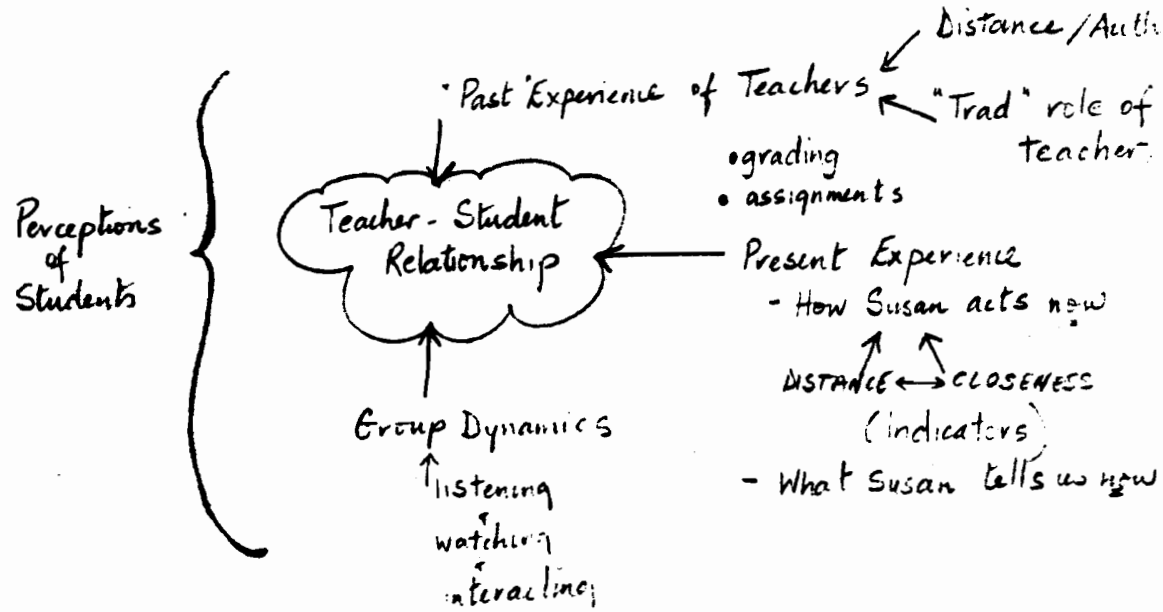




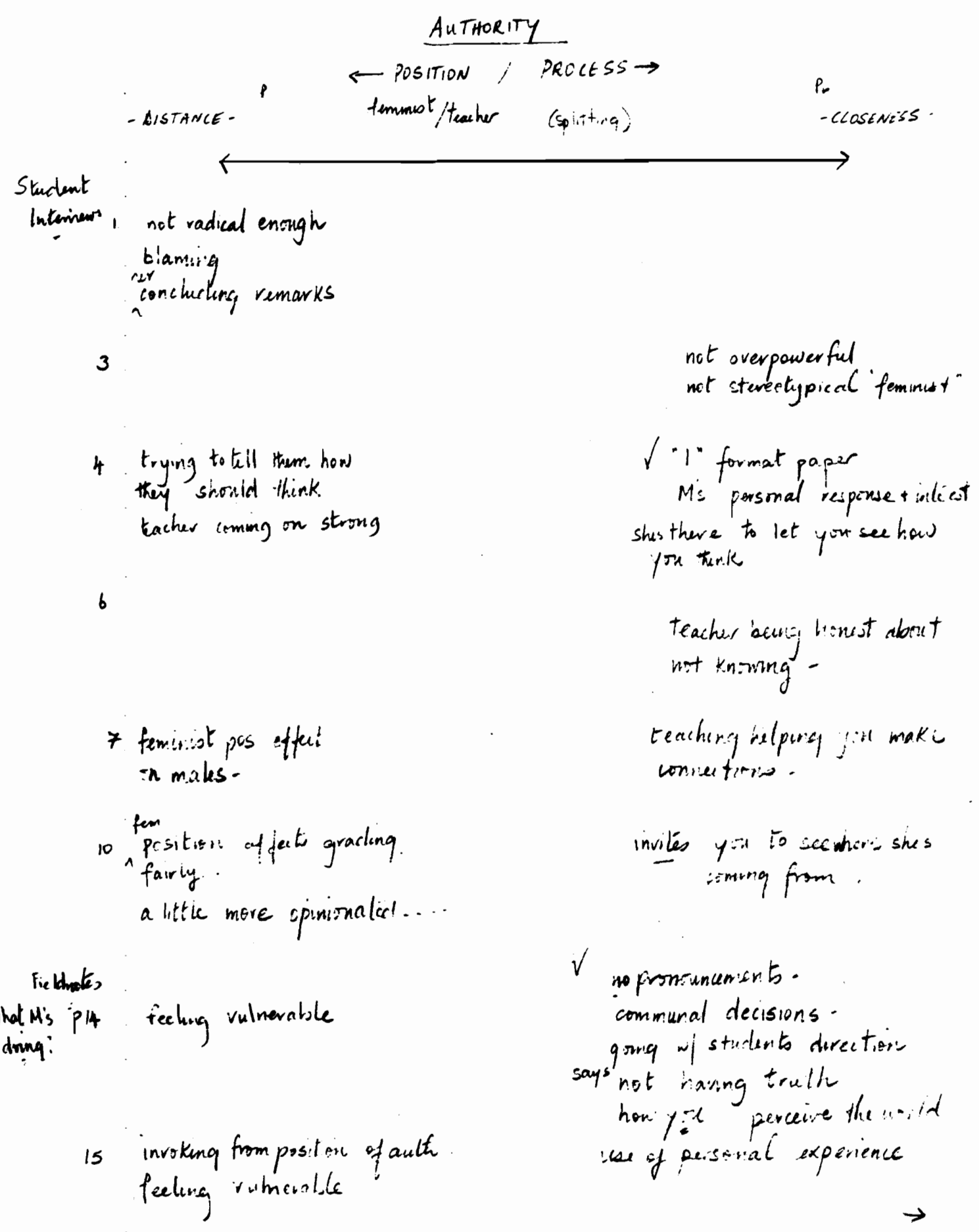


5

354

p 16. nitpicking

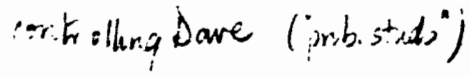

M. Ells wa how ho

interpet oni exps

assigns. unfinished-Minukes

$m=0 r: \log : 2 s$

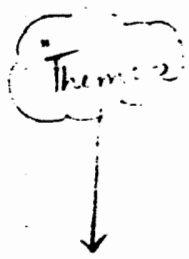

public reflection + reevaluatien. of position

says fem ped as velinguwhing aritt. says not having right arwwer.

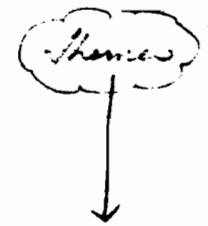

- Vurbar Peliriquelurig Authority

- Expicsifro Jharihg Perjovial Exp.

Solucatior:

Libiame helps you express younself 
VITA

\title{
ANNE PHELAN
}

1990 ,

Home Address

4, Cromer Apts

722 E. Roanoke St.

Blacksburg, VA 24060

(703) 552-3047

\author{
Office Address \\ Curriculum \& Instruction \\ 300 War Memorial Hall \\ Virginia Tech \\ Blacksburg, V A 24061
}

\section{OBJECTIVE}

Assistant Professor of Curriculum \& Instruction: to develop and teach undergraduate and graduate courses in elementary education: to maintain an active research agenda in the area of teaching and learning.

\section{EDUCATION}

Ed.D. (1990) (Teacher Education)

Curriculum \& Instruction Division

Virginia Polytechnic Institute \& State

University, Blacksburg, VA.

MA.Ed. (1987) (Reading and Language)

Curriculum \& Instruction Division

Virginia Polytechnic Institute \& State

University. Blacksburg, VA.

Diploma in Montessori Nursery Teaching (Hons.) (1986)

London Montessori Centre, London, England.

Certificate of Achievement in Education (Hons.) (1984)

Oslo University, Oslo, Norway.

B.Ed. (Hons.) (1980) Diploma in Religious Studies (Hons.) (1980) Mary Immaculate College of Education, Limerick, Ireland.

\section{PROFESSIONAL EMPLOYMENT HIGHER EDUCATION EXPERIENCE}

University Instructor (Graduate Assistantship).

Diagnosis and Treatment of Reading Disabilities.

Curriculum \& Instruction Division.

College of Education

Virginia Tech

Blacksburg, VA. (Spring 1987, 1988. and 1989)

-Designed syllabus

- Conducted class

- Directed case study development and analysis

- Administered and graded examinations 
Perspectives on Elementary and Middle School Education Curriculum \& Instruction Division

College of Education

Virginia Tech

Blacksburg. VA

(Fall, 1989: Spring, 1990)

- Coordinated field-based practicum

- Supervised student-aides

- Consulted with principals and co-operating teachers

- Devised syllabus

- Taught course

\section{University Supervisor of Student Teachers}

Curriculum \& Instruction Division

College of Education

Virginia Tech,

Blacksburg, VA.

(Sept. 1986-1989)

- Negotiated student placements

- Supervised student teachers

- Conferenced with student teachers and co-operating teachers

- Organized and facilitated student teacher seminars

\section{PUBLIC SCHOOL EXPERIENCE}

Elementary School Teacher

Our Lady of Mercy Primary School, Waterford. Ireland.

(Sept. 1980-1986)

- Instructed in all subject areas

- Taught 3rd, 4th, and 6th grades

\section{READING AND LANGUAGE EDUCATION EXPERIENCE}

\section{Literacy Instructor}

Hawaii Tutoring Agency, Honolulu. (June - August, 1989)

- Diagnosed reading disabilities in adults and children

- Prescribed and implemented corrective instructional strategies

\section{Reading Specialist}

The Reading Clinic, Curriculum \& Instruction Division. Virginia Tech,

Blacksburg, VA.

- Served as diagnostician and consultant on contract basis 


\section{Adult Literacy Tutor}

Vocational and Technical School. Waterford, Ireland. (Part-time. Sept. 1984-1985)

- Instructed illiterate adults in reading and writing processes

\section{Remedial Reading Tutor}

State Rural Remedial Scheme, Waterford, Ireland. (Part-time, Sept. 1981-1983)

- Taught children with learning disabilities in reading

\section{PROFESSIONAL ACTIVITIES}

\section{Doctoral Research}

An Examination of Teaching as Practical Political Activity

- Conducted a qualitative, ethnographic study

- Observed and interviewed three academic feminists and their students and colleagues over one academic year

- Examined the notion of teacher as an agent of social change

- Will generate insights and questions regarding teaching and learning as processes in the development of social justice and democratic societies

\section{Presentations}

Feminist Pedagogy: a Political or Educational Commitment to be presented to Southeastern Women's Studies Association Annual Meeting. Salem, VA. (March, 1990)

Some Principles of the New Scholarship on Women, with James Garrison, presented to the South Atlantic Philosophy of Education Society annual meeting, Willmington, NC. (April, 1989)

Gender and Post-positivistic Philosophy of Science, with James W. Garrison, presented to Virginia Educational Studies Association. Fredricksburg, VA. (October, 1988)

\section{Publications}

Toward a Feminist Poetic of Critical Thinking. with James W. Garrison, in the Philosophy of Education 1989: Proceedings of the Forty-fifth Annual Meeting of the Philosophy of Education Society.

The 4Cs of the New Scholarship on Women. with James W. Garrison, in the Proceedings of the Thirty-fourth Annual Meeting of the South Atlantic Philosophy of Education Society. 


\section{Conferences}

American Educational Research Association Annual Conference (1990). Boston. MA.

National Reading Conference (1987), St. Petersburg. FL.

Virginia Science-Education Conference (1987). Richmond, VA.

\section{SCHOLARSHIPS AND AWARDS}

Instructional Fee Scholarship

Curriculum \& Instruction Division, College of Education, Virginia Tech,

Blacksburg, VA. $(1986,1987,1988,1989)$

Nomination for Cunningham Fellowship (University Award)

Curriculum \& instruction Division. College of Education. Virginia Tech,

Blacksburg, VA.

Government of Norway International Scholarship

To attend International Summer School at Oslo University. Oslo, Norway.

(June - August, 1984)

Bronze, Silver, and Gold Medals in Speech and Drama

From London Academy of Music and Dramatic Art. London. England. (March, 1975, 1976, and 1977)

\section{INVOLVEMENTS}

President, International Club

Virginia Tech, Blacksburg, VA. (1988 - 1989).

Chairperson, International Week

Virginia Tech, Blacksburg, VA. (1988-1989)

\section{INTERESTS}

International Travel; Reading; Walking: Sketching

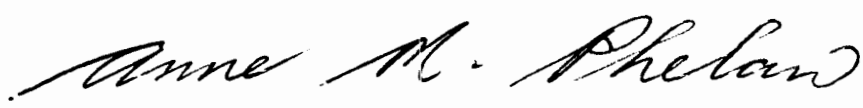

